\title{
POTENCIALIDADE DE CRUZAMENTOS QUÁDRUPLOS DE SOJA COM ÊNFASE NA PRODUTIVIDADE DE GRÃOS
}

\section{LUÍS FERNANDO ALLIPRANDINI}

Engenheiro Agrônomo

Orientador: Prof. Dr. NATAL ANTONIO VELLO

Tese apresentada à Escola Superior de Agricultura "Luiz de Queiroz" da Universidade de São Paulo, para a obtenção do título de Doutor em Agronomia, Área de Concentração: Genética e Melhoramento de Plantas.

\section{PIRACICABA}

Estado de São Paulo - Brasil Junho - 1996 
Dados Internacionais de Catalogação na Publicação (CIP) DIVISĀO DE BIBLIOTECA E DOCUMENTAÇĀO - Campus "Luiz de Queiroz"/USP

Alliprandini, Luis Fernando Potencialidade de cruzamentos quádruplos de soja com ênfase na produtividade de grãos / Luís Fernando Alliprandini. - Piracicaba, 1996. $174 \mathrm{p}$. : il.

Tese (doutorado) - - Escola Superior de Agricultura Luiz de Queiroz, 1996.

Bibliografia.

1. Soja - Cruzamento - Avaliação 2. Soja - Grão - Produtividade I. Título 


\section{POTENCIALIDADE DE CRUZAMENTOS QUÁDRUPLOS DE SOJA COM ÊNFASE NA PRODUTIVIDADE DE GRÃOS}

\section{LUIS FERNANDO ALLIPRANDINI}

Aprovada em: 26.06.1996

Comissão julgadora:

Prof. Dr. Natal Antonio Vello

ESALQ/USP

Prof. Dr. José Branco de Miranda Filho

ESALQ/USP

Prof. Dr. Gerhard Bandel

ESALQ/USP

Prof. Dr. Antonio Orlando Mauro

FCAVJ/UNESP

Dr. Luiz Alberto Rocha Batista

CPPSE/EMBRAPA

$$
\eta=1=1,11 \%
$$

Prof. Dr. NATAL ANTONIO VELLO Orientador 
À minha esposa Paula

Às minhas filhas Marina

e Camila, ofereço.

À meus pais, Perci e Wanda, meu irmão Percy e avós, dedico.

À Deus, por mais esta etapa, homenageio com gratidão. 


\section{AGRADECIMENTOS}

Em especial ao Professor Dr. Natal Antonio Vello, pela valiosa orientação, amizade e estímulo.

À ESALQ, professores e funcionários, pela oportunidade, ensinamentos e condições de trabalho oferecidas.

Ao $\mathrm{CNPq}$, pelo apoio financeiro durante o curso.

Aos colegas de curso e em especial de laboratório: Ângela, Baldin, Dario, Francilene, Gilberto, João Tomé, Joaquim, Lafayete, Mônica, Milton, Sérgio e Regina, pelo convívio e auxílio na condução do ensaio em Piracicaba.

Aos colegas Nelson Fonseca Júnior, Carlos Arrabal Arias e Sergio A. M. Carbonell e ao Dr. Roland Vencovsky pelas sugestões.

À Silvana Marchizelli Gregório pela revisão das referências bibliográficas.

Às secretárias Cândida Vanderléia de Oliveira e Carmen M.S. Fernandez Pilloto, pelo cordial atendimento.

Aos funcionários Antônio Roberto Cogo, Claudio Segatelli, Claudinei Antonio Didoné, José Guerreiro, José Roberto Alonso, Marcos Custódio Nekatschalow e Osmair José da Silva, pelo auxílio no experimento e amizade.

Às bibliotecárias Aparecida Elisabeth dos Santos e Kátia Maria de Andrade Ferraz, pela amizade e atenção dispensada.

À Cooperativa Agrícola Mista da Colônia Riograndense e funcionários: Cleonice, Aparecida, Josmardo Félix, Juraci, Pedro, Cícero e José Carlos pelo auxílio na condução do experimento em Maracaí.

À banca examinadora pelas valiosas sugestões.

À minha esposa Paula Mariza, pelo constante estímulo e amor. 


\section{SUMÁRIO}

RESUMO ix SUMMARY xii

\section{INTRODUÇÃO} 1

2. REVISÃO DE LITERATURA .........................................................4

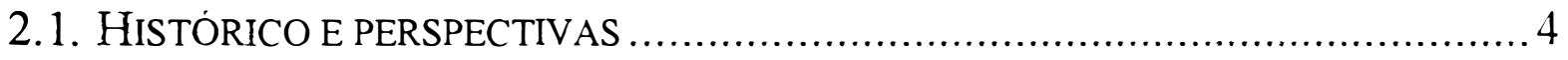

2.2. USO DE CRUZAMENTOS MÚLTIPLOS EM PLANTAS AUTÓGAMAS ..................6

2.3. SELEÇÃO RECORRENTE EM PLANTAS AUTÓGAMAS ................................ 11

2.3.1. Aspectos gerais ......................................................................... 11

2.3.2. Escolha do material genético inicial ............................................ 13

2.3.3. Recombinação genética .............................................................. 14

2.3.4. Manutenção da variabilidade genética durante a seleção................ 17

2.3.5. Herança do tempo para florescimento e maturidade, altura de planta, valor agronômico e produtividade de grãos em soja .............................. 19

2.3.6. Correlações entre caracteres ........................................................... 21

2.3.7. Seleção em populações segregantes................................................. 24

3. MATERIAL E MÉTODOS................................................................31

3.1. OBTENÇÃO DOS CRUZAMENTOS QUÁdRUPLOS E DA GERAÇÃO $F_{1[4]} \ldots \ldots \ldots . . . . .31$

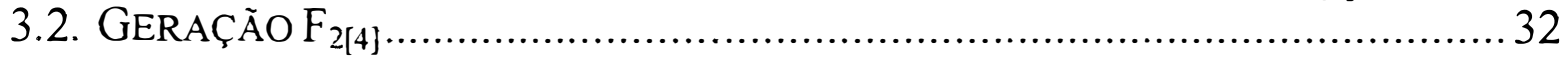

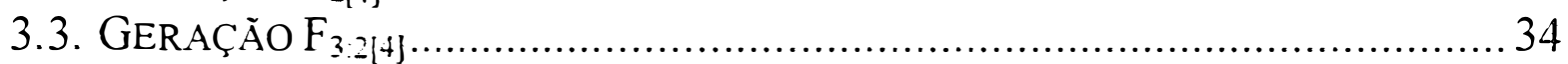

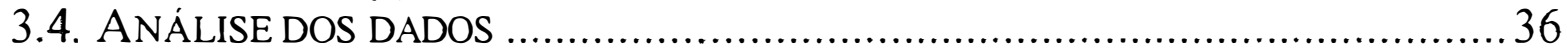

3.4.1. Análise individual dos parentais e populações em cada geração...... 36

3.4.2. Análises de variância e covariância................................................. 37

3.4.3. Correlações entre caracteres........................................................... 38

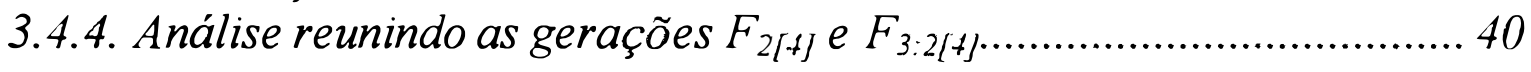

4. RESULTADOS E DISCUSSÃ O........................................................43

4.1. ANÁliSE dOS PARENTAIS COM BASE EM PLANTAS INDIVIDUAIS.................. 43

4.1.1. Florescimento e Maturidade ........................................................ 43

4.1.2. Valor Agronômico (VA) e Produtividade de Grãos (PG) .................. 47

4.2. ANÁLISE DAS POPULAÇÕES E TESTEMUNHAS COM BASE EM PLANTAS

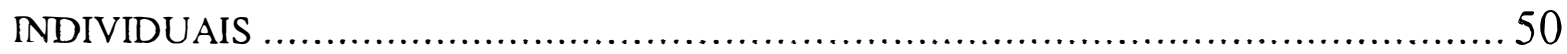

4.2.1. Florescimento e Maturidade .........................................................5 50

4.2.1.1. Número de Dias para o Florescimento (NDF) .........................50 
4.2.1.2. Altura da Planta no Florescimento (APF) ................................5 52

4.2.1.3. Número de Dias para a Maturidade (NDM) ..............................54

4.2.1.4. Altura da Planta na Maturidade (APM) ....................................56

4.2.2. Valor Agronômico (VA) e Produtividade de Grãos (PG) .................. 59

4.2.2.1. Valor Agronômico (VA) .......................................................59

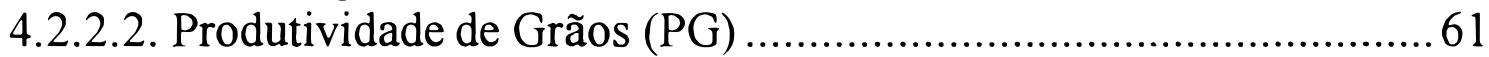

4.3. ANÁLISES COM BASE NA MÉDIA DE REPETIÇÕES .......................................64 64

4.3.1. Análises de variância por ambiente ...............................................64 64

4.3.2. Análises de variância conjuntas em dois ambientes para parentais e testemunhas .................................................................................................6 66

4.4. AGRUPAMENTO DE MÉDIAS PELO CRITÉRIO DE SCOTT-KNOTT....................67 67

4.4.1. Agrupamento de médias de 20 parentais ........................................6 68

4.4.2. Agrupamento de médias de 45 populações e quatro testemunhas ... 71

4.4.2.1. Florescimento e Maturidade................................................. 72

4.4.2.2. Valor Agronômico (VA) e Produtividade de grãos (PG) ............ 74

4.5. CORRELAÇÕES ENTRE CARACTERES ....................................................76

4.5.1. Correlações fenotipicas, genotipicas e residuais entre caracteres ... 76

4.5.1.1. Número de Dias para o Florescimento (NDF)........................... 77

4.5.1.2. Altura da Planta no Florescimento (APF) ................................78

4.5.1.3. Número de Dias para a Maturidade (NDM) ............................ 79

4.5.1.4. Altura da Planta na Maturidade (APM) ................................... 80

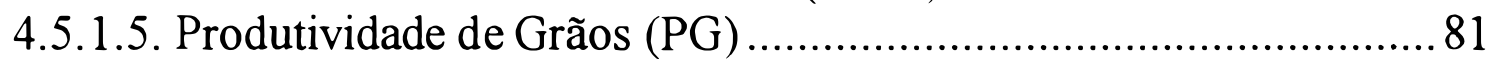

4.5.2. Correlações fenotipicas de Pearson ................................................ 82

4.6. CONSIDERAÇÕES SOBRE ANÁLISES, REUNINDO-SE AS GERAÇÕES $F_{2[4]} E$ $\mathrm{F}_{3: 2[4]}$....

4.6.1. Correlações fenotipicas de Spearman entre os caracteres nas

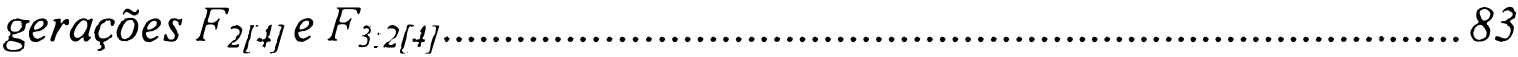

4.6.2. Herdabilidades no sentido restrito ................................................. 86

4.6.3. Seleção dentro das populações ........................................................8 88

4.6.3.1. Seleção para Produtividade de Grãos (PG )..................................89

4.6.3.2. Seleção para Valor agronômico (VA) ........................................ 90

4.6.3.3. Seleção conjunta para Produtividade de Grãos + Valor Agronômico $(\mathrm{PG}+\mathrm{VA})$

4.6.3.4. Seleção conjunta para Produtividade de Grãos + Número de dias para a Maturidade (PG + NDM) .................................................... 92 4.6.3.5. Seleção conjunta para Produtividade de Grãos + Valor Agronômico + Número de dias para a Maturidade (PG+VA+NDM) .......................... 94 4.6.4. Considerações finais..................................................................... 95 
REFERÊNCIAS BIBLIOGRÁFICAS............................................99

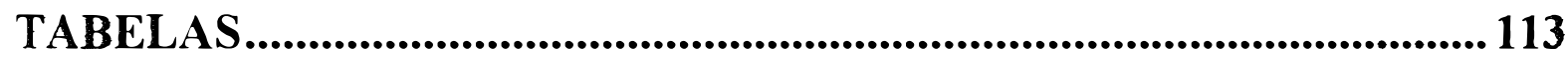

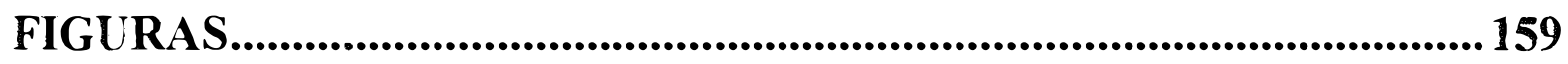

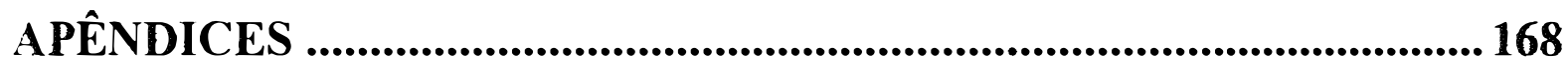




\title{
POTENCIALIDADE DE CRUZAMENTOS QUÁDRUPLOS DE
} SOJA COM ÊNFASE NA PRODUTIVIDADE DE GRÃOS

\author{
Autor: LUÍS FERNANDO ALLIPRANDINI \\ Orientador: PROF. DR. NATAL ANTONIO VELLO
}

\section{RESUMO}

Este trabalho teve por objetivo avaliar a potencialidade de cruzamentos quádruplos [4] em soja (Glycine max (L.) Merrill), visando-se a seleção de cruzamentos superiores com ênfase na produtividade de grãos. Foram utilizadas as gerações $F_{2[4]}$ e $F_{3: 2[4]}$ de 45 populações obtidas por cruzamentos quádruplos pelo programa de seleção recorrente conduzido no setor de Genética Aplicada às Espécies Autógamas, Departamento de Genética, ESALQ/USP.

A síntese das populações iniciou-se com a escolha de 20 parentais, sendo dez com ciclo semi-tardio e dez com ciclo tardio. A primeira recombinação envolveu dois dialelos, com obtenção de $90 \mathrm{~F}_{1}$ 's, sendo $45 \mathrm{~F}_{1}$ 's entre parentais semi-tardios e $45 \mathrm{~F}_{1}$ 's entre parentais tardios. A segunda recombinação compreendeu 45 cruzamentos entre os $F_{1}$ 's, combinando-se um $F_{1}$ do dialelo semi-tardio com outro $F_{1}$ do dialelo tardio, obtendo-se 45 cruzamentos quádruplos $\left(\mathrm{F}_{[[4]}\right)$. 
No total, foram instalados quatro experimentos delineados em blocos ao acaso com 4 testemunhas comuns (cultivares Cristalina, EMGOPA-301, IAC-8 e SS-1) em todas as repetições. A parcela constou de seis e 12 plantas individuais (covas espaçadas de $80 \times 80 \mathrm{~cm}$ ), respectivamente nos experimentos com parentais e com populações segregantes. Em 04/12/92 foram instalados em Piracicaba-SP dois experimentos, o primeiro envolvendo quatro repetições das 45 populações em $\mathrm{F}_{2[4]}$ e as quatro testemunhas e 0 segundo experimento contendo duas repetições dos 20 parentais com as quatro testemunhas. Em 02/12/93 foram instalados em Maracaí-SP outros dois experimentos semelhantes aos do ano anterior, com a diferença de que as 45 populações continham plantas $\mathrm{F}_{3: 2[4]}$. $\mathrm{O}$ avanço de geração foi feito pelo método SHDT ("Single Hill Descent Thinned"), pelo qual cada planta $F_{2[4]}$ foi representada por uma cova com 15 sementes, deixando uma planta individual $F_{3: 2[4]}$ por cova, após o desbaste no estádio $V_{2}$.

Nos quatro experimentos foram avaliadas todas as plantas individuais para os seguintes caracteres: número de dias para o florescimento (NDF) e para a maturidade (NDM); altura da planta no florescimento (APF) e na maturidade (APM); valor agronômico (VA) e produtividade de grãos (PG).

Inicialmente, as análises estatístico-genéticas foram realizadas a partir de dados de plantas individuais, estimando-se médias, amplitudes, variâncias entre plantas, herdabilidades no sentido amplo e razões entre o coeficiente de variação genética e o coeficiente de variação experimental. Posteriormente, a partir de médias de parcelas foram feitas análises de variância e covariância para estimação de correlações fenotípicas, genotípicas e residuais entre os caracteres; herdabilidade no sentido restrito e associação entre as gerações $F_{2[4]}$ e $F_{3: 2[4]}$ para cada caráter. Foi simulada uma seleção dentro de cada população 
$\mathrm{F}_{2[4]}$, avaliando-se o ganho genético obtido em $\mathrm{F}_{3: 2[4]}$ com a construção de um índice prático de seleção.

Os resultados levaram às seguintes conclusões: a) os parentais mostraram interação de genótipos por ambientes para os seguintes caracteres: ciclo (NDF e NDM), VA e PG. Destacaram-se os parentais Cristalina, EMGOPA-301, IAC-9 e SS-1 nos dois ambientes avaliados, com elevados valores de PG e VA; b) o método SHDT, foi eficiente para conduzir grande número de populações com tamanho efetivo adequado $(\mathrm{N}=39$ plantas em média) e por exigir pequeno número de sementes de cada genótipo com menor área experimental; c) cruzamentos quádruplos entre parentais semi-tardios e tardios proporcionaram elevada variabilidade genética nas populações obtidas, produzindo segregantes superiores em VA e PG. d) para a maioria das populações, não houve redução da variabilidade genética entre as gerações $F_{2[4]}$ e $F_{3: 2[4]}$. e) Antes e após a seleção, destacaram as populações obtidas pelos seguintes cruzamentos quádruplos: população $20=(\mathrm{IAC}-4 \times$ IAC-8) X (GO79-1039 x Numbaíra); população 21 = (IAC-4 x IAC-9) X (GO79-1039 x Paranagoiana); população $22=($ IAC-4 $\times$ IAC-11) X $($ GO79-1039 $x$ Timbira); população $23=($ IAC-4 x Santa Rosa) $X$ (GO79-1039 x Tropical); população $24=($ IAC-4 x SS-1) X (GO79-1039 x White Biloxi); f) A seleção precoce de plantas em $\mathrm{F}_{2[4]}$, foi mais eficiente quando os caracteres PG, VA e NDM foram combinados em um índice de seleção, principalmente para as populações: $41,17,22,21,23,32,20,6,34$, e 24 , em ordem decrescente de PG. 


\title{
POTENTIALITY OF FOUR-WAY CROSSES OF SOYBEAN WITH EMPHASIS IN THE SEED YIELD.
}

\author{
Author: LUÍS FERNANDO ALLIPRANDINI \\ Adviser: PROF. DR. NATAL ANTONIO VELLO
}

\section{SUMMARY}

The main objective of this research was to evaluate the potentiality of four-way [4] crosses of soybean (Glycine max (L.) Merrill), in order to generate inbred lines superior in seed yield. The materials were $F_{2[4]}$ and $F_{2: 3[4]}$ generations of 45 populations synthesized through four-way crosses by the recurrent selection program carried out in the Departamento de Genética da Faculdade de Agricultura "Luiz de Queiroz" (ESALQ), Universidade de São Paulo (USP).

The synthesis of the populations began by choosing 20 parents, that are, ten parents with semi-late maturity and others ten parents with late maturity. The first recombination involved two diallels with the obtention of 90 two-way crosses, including $45 \mathrm{~F}_{\mathrm{I}}$ 's between semi-late parents and $45 \mathrm{~F}_{1}$ 's between late parents. The second recombination consisted in 45 crosses between $F_{1}$ plants, by combining one $F_{1}$ plant from semi-late diallel and one $F_{1}$ plant from late diallel; thus, it was obtained 45 different four-way crosses $\left(F_{1[4]}\right)$.

In total, it was carried out four experiments designed in ramdomized complete blocks with four common checks (the cultivars Cristalina, EMGOPA-301, IAC-8 and SS-1) in each replication. The experimental plot 
involved six and 12 individual plants (hills spaced $80 \mathrm{~cm} \times 80 \mathrm{~cm}$ ), respectively in the experiments with parents and segregating populations. In December 04, 1992, two experiments were planted in Piracicaba - SP: the first experiment involved four replications of the 45 populations in $\mathrm{F}_{2[4]}$ and the four checks; the second experiment consisted in two replications of the 20 parents with the four checks. In December, 02, 1993, it was sowed in Maracai-SP other two experiments designed similarly to the previous year, but with 45 populations of $\mathrm{F}_{2: 3[4]}$ plants. The generation advance was made by the SHDT (Single Hill Descent Thinned) method, in which one $\mathrm{F}_{2[4]}$ plant was represented by a hill of 15 seeds, remaining a single individual $F_{2: 3[4]}$ plant per hill, after thinning at $V_{2}$ stage.

In the four experiments, all individual plants were evaluated for the following characters: number of days to flowering (NDF) and maturity (NDM), plant height at flowering (APF) and maturity (APM), agronomic value (VA) and seed yield (PG).

Firstly, genetic-statistical analyses were made on an individual plant (hill) basis for estimating means, ranges of values, variance between plants, broad sense heritability and the ratio between genetic and experimental coefficients of variation. Secondly, variance and covariance analysis were made on a plot mean basis for estimating: phenotypic, genotypic and residual correlations between traits; narrow sense heritability and association between $F_{2[4]}$ and $F_{3: 2[4]}$ generations for each trait. It was simulated a selection within each $F_{2[4]}$ segregating population, in order to evaluate in the $F_{3: 2[4]}$ the genetic gain with a pratical selection index.

The results led to the following conclusions: a) parental analysis detected genotypes $x$ environments interaction for cicle (NDF and NDM), VA and PG. The parents Cristalina, EMGOPA-301, IAC-9 and SS-1 exceeded with 
superior performance for $\mathrm{VA}$ and $\mathrm{PG}$ in the two tested environments; b) the SHDT method was efficient for the management of great number of populations with appropriate $(\mathrm{N}=39$ plants, in average) effective size and requeriment of small seed number from each genotype; c) four-way crosses provided high genetic variability in the populations with the generation of segregating genotypes superior in VA and PG; d) the majority of populations did not present reduction in the genetic variability from $F_{2[4]}$ to $F_{2: 3[4]}$ generation; e) before and after selection, the following populations exceeded: population $20=($ IAC-4 $\times$ IAC-8) $X($ GO79-1039 x Numbaíra); population 21 $=($ IAC-4 $x$ IAC-9) X (GO79-1039 $\times$ Paranagoiana $)$; population $22=($ IAC $-4 \times$ IAC-1 1) X (GO79-1039 x Timbira); population $23=($ IAC-4 $\times$ Santa Rosa $) X$ (GO79-1039 x Tropical); population $24=($ IAC-4 x SS-1) $\times($ GO79-1039 x White Biloxi); f) the early generation selection of $F_{2[4]}$ plants was more efficient when the PG, VA and NDM characters were combined in a selection index, mainly for the populations $41,17,22,21,23,32,20,6,34,24$ (in decreasing rank of $P G)$. 


\section{INTRODUÇÃO}

No Brasil, a cadeia agro-industrial da soja (Glycine max (L.) Merrill) é uma das que mais se destacam, tanto pela sua expressiva participação na pauta de exportações sob a forma de farelo, óleo e grãos, como também para o suprimento do mercado interno de óleos comestiveis protéicos. Em 1994, a soja foi responsável pela maior receita agrícola brasileira, contribuindo com cerca de 5.966 mil dólares, seguida pelo milho que obteve neste período receita de 4.406 mil dólares, pelo feijão com 3.823 mil e pelo arroz com 2.529 mil dólares (HOMEM DE MELO, 1995).

O cultivo da soja no Brasil tem aumentado muito nestes últimos anos, através da incorporação de novas áreas que hoje abrangem regiões que vão desde os Estados da Região Sul até o sul dos Estados do Maranhão e Piauí. Isto se deu graças ao esforço da pesquisa no desenvolvimento de novas técnicas de cultivo e novos cultivares adaptados às diferentes condições edafoclimáticas. Na safra 1994/95, em uma área cultivada de cerca de 11,7 milhões de hectares, a soja atingiu a maior produção de sua história, em torno de 26,4 milhões de toneladas (SOUSA, 1995).

SPEHAR (1994) destacou a importância do desenvolvimento de cultivares de ciclo longo, como 'FT-Cristalina', 'Doko', 'EMGOPA-301', 'Numbaira', 'BR-9 (Savana)', 'BR-15 (Mato Grosso)' e 'BR-40 (Itiquira)', para os sistemas de produção regionais de baixas latitudes $\left(\leq 15^{\circ}\right)$ dos 
cerrados, destacando a possibilidade de aperfeiçoamento dos métodos de melhoramento para aumentar a eficiência na obtenção de novos cultivares.

Os genótipos de soja dos grupos semi-tardio e tardio geralmente têm alta produtividade de grãos, conseqüência da correlação positiva entre ciclo e produtividade, além do que, estes dois grupos reúnem os genótipos mais apropriados para a "safrinha" no Estado de São Paulo, com semeadura atrasada para janeiro a março (VELLO, 1992).

A genética pode contribuir de duas maneiras para viabilizar o cultivo da soja em condições de dias curtos ("safrinha" ou cultivo de outono/inverno, com semeadura atrasada para janeiro a março; baixas latitudes). Uma possibilidade são os genes para hábito de crescimento indeterminado $\left(\begin{array}{lllll}\mathrm{Dt}_{1} & \mathrm{Dt}_{1} & \mathrm{dt}_{2} & \mathrm{dt}_{2} & \text {; }\end{array}\right.$ BERNARD, 1972), os quais permitem a continuidade do crescimento vegetativo da planta, concomitantemente com o florescimento. Uma segunda possibilidade, que tem se mostrado mais promissora, são os genes para florescimento tardio ou período juvenil longo (PJL). A herança do PJL ainda não está bem esclarecida, podendo envolver poucos (um a quatro) genes recessivos (KIIHL \& GARCIA, 1989; DESTRO, 1991; RAY et al., 1995) e/ou poligenes (TOLEDO et al. 1993, TOLEDO et al., 1994). Os genes para PJL conferem à planta tolerância ao fotoperíodo, através de um atraso na resposta da planta às condições fotoperiódicas indutoras do florescimento.

A maioria quase absoluta dos cultivares recomendados no Brasil (aproximadamente 200), foram obtidos através de introdução de plantas, seguida de cruzamentos (e retrocruzamentos) biparentais. Este grande sucesso obtido até agora dificilmente poderá ser continuado, em razão de: a) base genética estreita do germoplasma cultivado, conseqüência principalmente do uso repetitivo de um pequeno número de genótipos parentais e da recombinação insuficiente promovida por uma única geração de cruzamentos 
biparentais em cada ciclo; b) aumento expressivo da área cultivada com soja no Brasil. Estes dois últimos fatores têm sido apontados como responsáveis pelo estabelecimento de patamares de produtividade e pela vulnerabilidade do germoplasma às condições estressantes, principalmente doenças (VELLO, 1995).

A utilização de técnicas, como a realização de cruzamentos múltiplos e seleção recorrente, promovendo a recombinação e reorganização de novas combinações favoráveis para vários caracteres, gerando maior variabilidade e ganhos genéticos acentuados, parecem ser uma esperança para se evitar, no futuro, problemas semelhantes aos que recentemente têm causado grandes prejuízos à sojicultura nacional, como os provocados pelo cancro da haste e pelo nematóide de cisto. Entende-se por cruzamento múltiplo, todo o cruzamento envolvendo a participação de mais do que dois genótipos parentais de constituições genéticas diferentes.

Esta pesquisa foi delineada envolvendo as gerações $F_{2}$ e $F_{3: 2}$ de cruzamentos quádruplos, envolvendo 20 parentais de soja com ciclos semitardio e tardio, segundo o programa de seleção recorrente para produtividade de grãos descrito por VELLO (1992), e tem como objetivos:

a) avaliar a potencialidade de cruzamentos quádruplos, envolvendo 20 parentais, para aumento da produtividade de grãos em soja, estudando-se a variabilidade gerada nas gerações iniciais, associações e relações entre caracteres em cada geração e entre as gerações, relativamente aos 20 parentais.

b) selecionar cruzamentos e parentais superiores, fornecendo subsídios para continuidade de programas de seleção recorrente envolvendo genótipos de soja semi-tardios e tardios. 


\section{REVISÃO DE LITERATURA}

\subsection{Histórico e perspectivas}

A soja (Glycine max (L.) Merrill) é uma espécie de auto-polinização originária da Ásia, mais provavelmente do Centro de Origem Chinês, tendo sido introduzida no Brasil em 1882. A expansão da soja em nosso país registrou níveis significativos a partir de 1968, sendo cultivada nos Estados do Rio Grande do Sul, Santa Catarina, Paraná, São Paulo, Mato Grosso, Minas Gerais e Goiás (MIYASAKA \& MEDINA, 1981)

A partir de 1973, a participação do valor bruto da produção de soja brasileira no PIB agrícola foi sempre maior que $10 \%$, sendo que a partir da década de 80, com a incorporação de novas áreas nos Estados de Mato Grosso do Sul, Mato Grosso, Tocantins, Distrito Federal, Bahia, Maranhão e Piauí, cultiva-se atualmente, por volta de 11,7 milhões de hectares (ROESSING \& GUEDES, 1993; SOUSA, 1995).

Com a incorporação de novas áreas de plantio, houve um significativo acréscimo na produção, mas nas áreas tradicionais, este aumento em produção não tem correspondido de maneira significativa ao potencial destas regiões, sendo que o ganho genético via melhoramento tem-se reduzido com o decorrer dos anos para cultivares de menor ciclo, sendo nulo para cultivares de ciclo 
médio (TOLEDO et al. 1990; ALLIPRANDINI, 1992; ALLIPRANDINI et al., 1993).

SPECHT \& WILLIAMS (1984), estimaram que os melhoristas dos EUA obtiveram ganhos de 18,8 Kg/ha/ano durante 1900-1980. Quando dividido em duas épocas distintas, estes autores verificaram que no período anterior à 1940 o melhoramento consistia basicamente de introduções, sendo que após este ano, houve um grande salto de $0,7 \mathrm{Kg} / \mathrm{ha}$ para $12,5 \mathrm{Kg} / \mathrm{ha}$, passando-se, então, a ter três fases: 1) Cruzamentos biparentais e parentais escolhidos anualmente; 2) Avanço de geração da população até um nível de endogamia desejado; 3) Avaliação das linhagens obtidas de cada um dos cruzamentos biparentais. Adiciona-se o fato de que melhorias nas diversas técnicas envolvidas na experimentação resultaram na redução dos erros experimentais, diminuindo-se efetivamente a fração não genética da variância fenotípica e conduzindo a maiores valores de coeficientes de herdabilidade. Este novo procedimento fez da recombinação gênica e seleção recorrente uma norma de rotina no melhoramento da soja (SPECHT \& GRAEF, 1990).

Segundo VELLO et al. (1988), o programa de melhoramento de soja no Brasil seria considerado como tendo uma população com tamanho efetivo relativamente baixo $(\mathrm{N}=11$ a 15$)$, mudando do segundo para o terceiro ciclo de seleção recorrente. A possível existência de patamares de produtividade e a vulnerabilidade dos cultivares, ocasionadas pela estreita base genética da soja (HIROMOTO \& VELLO, 1986), têm evidenciado a necessidade da utilização de técnicas eficientes de introdução, seleção e hibridação para que novos avanços possam ocorrer, elevando-se, assim, o potencial genotípico de produtividade dos cultivares comercializados.

No entanto, DUVICK (1984), previu poucas chances de mudanças através da utilização de maior variabilidade genética nas principais culturas, 
enumerando quatro razões: 1) as variedades ou híbridos continuarão a ser altamente uniformes; 2) os agricultores continuarão a semear um número pequeno de híbridos ou variedades de cada cultura; 3) os agricultores preferem resultados baseados na similaridade fenotípica dos diversos cultivares, dentro de uma mesma zona de cultivo; 4) a manutenção de blocos de ligação favoráveis resulta num alto grau de parentesco entre cultivares de uma área de adaptação.

A proposta de utilização de cruzamentos múltiplos entre linhagens parentais com certa divergência genética e de comprovada aceitação pelos agricultores, com posterior seleção recorrente, parece ser uma boa alternativa para obtenção de novas combinações favoráveis para a solução dos problemas (itens anteriores: 1, 3 e 4) levantados por Duvick (1984).

\subsection{Uso de cruzamentos múltiplos em plantas autógamas}

O método clássico de melhoramento em espécies autógamas tem sido o cruzamento de dois parentais superiores, seguido do desenvolvimento de linhagens homozigóticas através de gerações sucessivas de autofecundação. Linhagens superiores são então identificadas por testes de produtividade e utilizadas como novos cultivares e/ou como parentais em novos cruzamentos. A fragilidade deste método é que um limitado "pool gênico" é usado para cada cruzamento. Como este ciclo é muito longo (5-10 anos), o acréscimo de produtividade a cada ano pode ser pequeno (ROSE et al., 1992).

Segundo FREY (1976), o uso de cruzamentos múltiplos foi proposto por H.V. Harlan e colaboradores em 1940, através de um modelo envolvendo 16 ou 32 parentais cruzados em sucessivas gerações de cruzamentos simples, 
quádruplos e óctuplos, proporcionando-se, assim, recombinação entre genes de diferentes linhagens parentais.

De acordo com HANSON (1959), a extensão com que blocos de ligação são quebrados e recombinados, é de grande importância para o melhorista, uma vez que todo programa de melhoramento depende sobretudo da obtenção de recombinações genéticas desejadas. Baseando-se na análise da quebra de blocos de ligação, é evidente que um programa de melhoramento para espécies autógamas deveria incluir mais de uma geração de intercruzamentos (preferencialmente três ou quatro).

A recombinação genética dentro de grupos de ligação é extremamente limitada, especialmente para cromossomos curtos, a menos que ciclos de intercruzamentos estejam incluídos no programa de melhoramento. A inclusão de quatro ou mais parentais na população, poderia aumentar o potencial genético da população, efetuando-se também, uma grande redução no tamanho dos blocos de ligação que estavam intactos nos parentais, comparativamente à uma população sintetizada com somente dois parentais (HANSON, 1959).

HANSON \& HAYMAN (1963), em um estudo teórico a partir de populações formadas de cruzamento entre parentais homozigóticos, com diferentes proporções de ligações em associação e intercruzamento após a geração $F_{2}$, destacaram que na presença de blocos de ligação, o intercruzamento anterior à seleção dos parentais poderia decrescer a variabilidade genética e também o progresso genético imediato. Indicaram, ainda, a importância de favorecer a oportunidade para recombinação e a utilização de algum programa de seleção recorrente, que permita a recombinação ocorrer sob pressão de seleção, favorecendo a busca do genótipo idealizado. 
FALCONER (1987) estabeleceu que as mudanças esperadas nos parâmetros da população como resultado de intercruzamentos, seriam determinadas pelo relações de ligação predominantes na população e que as freqüências genotípicas e variâncias genéticas tenderiam a mover-se através de valores do equilíbrio, após repetidos intercruzamentos. Se ligações em repulsão predominassem, intercruzamentos tenderiam a aumentar a variância genética e a freqüência de genótipos contendo alelos favoráveis ligados. Se ligações em associação predominassem, a variância genética tenderia a decrescer devido à redução no número de genótipos nos quais os alelos favoráveis ou desfavoráveis estão em ligação.

$\mathrm{O}$ benefício esperado de intercruzamento de uma população $F_{2}$, proveniente de dois parentais homozigotos, seria quando os loci dos alelos estivessem inicialmente em fase de repulsão. Se os loci estivessem distribuídos em mais de três cromossomos, então o ganho esperado por intercruzamentos seria consistentemente pequeno (PEDERSON, 1974; BOS, 1977). Estes autores demonstraram, ainda, que intercruzamentos ao acaso poderiam não ser esperados como sendo superiores à seleção em gerações precoces.

GATES et al. (1960) observaram que o efeito de ligação, foi importante para várias características da soja, como: florescimento, altura de planta e produtividade de grãos, sendo que o contrário foi observado para maturidade e período reprodutivo.

Ao contrário do grande e crescente número de coleções de germoplasma, a participação de parentais múltiplos é limitada. JENSEN (1970) enumerou três defeitos do melhoramento convencional de cereais, no qual a variabilidade e a recombinação potencial são baixas devido ao conjunto gênico inicialmente restrito, com posterior redução da recombinação genética devido à ligação. A endogamia e a ausência de intercruzamentos intensificam os efeitos de ligação 
e, assim, logo se fecha qualquer opção de recombinação fora da estreita família de linhagens descendentes. JENSEN (1970) ainda propõe o uso de um cruzamento seletivo para espécies autógamas, utilizando parentais múltiplos inseridos em um conjunto gênico central (população), a qual, através de cruzamentos seletivos de indivíduos, seria avançada por gerações sucessivas.

A implementação envolveria quatro etapas: 1) série básica de cruzamentos parentais; 2) dialelos entre $F_{1} s$, os quais formariam um composto $\left.\mathrm{P}_{2} ; 3\right)$ séries de cruzamentos seletivos intra e inter-populacional praticados com as populações $P_{1}, P_{2}, \ldots, P_{n}$, sob princípios de seleção massal e recorrente; (4) seleção de linhagens $F_{5}$ das populações compostas.

De acordo com FREY (1976), com este método todas as possíveis combinações biparentais seriam feitas entre (n) parentais selecionados e, dependendo do número de $\mathrm{F}_{1} \mathrm{~S}$, um dialelo parcial entre estes poderia providenciar material para o início de uma nova população a ser melhorada. Esta população poderia ser avançada para $F_{2}$ e, subseqüentemente, muitos cruzamentos ao acaso poderiam ser feitos entre plantas $F_{2}$ selecionadas. As seleções seguidas de intercruzamentos poderiam ser continuadas em cada geração ou em gerações alternadas, visando-se a maximização da heterozigosidade, através da permuta e recombinação entre alelos em loci ligados provindos da matriz multiparental. Outros esquemas e aplicações de cruzamentos múltiplos são discutidos e avaliados no melhoramento de culturas autopolinizadas.

FOUILLOUX \& BANNEROT (1988) descreveram os dois principais métodos de intercruzamentos como: 1) modelos piramidais e cônicos; 2) com o uso de macho-esterilidade. O modelo piramidal preconiza a necessidade do cruzamento de indivíduos altamente heterozigotos, isto é, híbridos $F_{1}$, híbridos duplos, etc. 
Uma variante mais fácil deste modelo, o cônico, é obtido pelo uso de $\mathrm{N}$ parentais $\left(l_{1}, l_{2}, \ldots, l_{N}\right)$, com cruzamentos $1_{1} \times l_{2}, l_{2} \times l_{3}$, etc., obtendo-se os híbridos $F_{1} s 12,23,34$, etc. Cada híbrido $F_{1}$, por sua vez, é cruzado com $o$ próximo híbrido $F_{1}$ sem parentais comuns: $12 \times 34,23 \times 45, \ldots,(n-1) n \times$ 12, para obter híbridos duplos $1234,2345, \ldots,(n-1) n 12$ e então continuar as próximas etapas de cruzamentos seguindo as mesmas regras. Este modelo permite conservar a diversidade de citoplasmas convencionais com a utilização de qualquer número de parentais.

O uso de macho esterilidade, leva a um grande número de intercruzamentos sem intervenção manual, podendo reduzir os custos.

MATZINGER \& WERNSMAN (1968), trabalhando com fumo, avaliaram em quatro ciclos de seleção massal, a importância do uso de cruzamentos múltiplos maximizando a recombinação genética. BRIM (1976), apresentou diversos esquemas de seleção recorrente, com elevado número de cruzamentos naturais obtidos através de plantas macho-estéreis.

FEHR (1978) sugeriu um esquema, para se formar uma população de intercruzamentos iniciada com cruzamentos simples de oito parentais, seguidos de cruzamentos duplos e múltiplos, com posterior autofecundação. PAVONI (1989) descreveu o desenvolvimento de populações de trigo com base genética ampla, intensamente recombinada por cruzamentos múltiplos.

Um outro método que otimiza a recombinação genética e, conseqüentemente, a variabilidade genética, através de cruzamentos múltiplos anuais, foi proposto por SPECHT \& GRAEF (1990). Neste caso, populações $\mathrm{F}_{2}$ são geradas a cada ano, provenientes de cruzamentos múltiplos anuais, servindo como população básica para avanço de gerações, seleção ou para cruzamentos com novos parentais elites. 
A utilização de cruzamentos múltiplos em plantas autógamas tem sido avaliada na obtenção de ganhos genéticos mais elevados em vários caracteres. Diversos trabalhos são relacionados em uma revisão feita por GOLDRINGER \& BRABANT (1993), pela qual populações foram desenvolvidas a partir de cruzamentos entre dois ou múltiplos parentais, fornecendo subsídios para a prática de seleção recorrente.

Contudo, no Brasil não são encontrados trabalhos que avaliem a potencialidade de cruzamentos múltiplos no melhoramento de soja para produtividade de grãos, incluindo neste contexto a variabilidade gerada pela seqüência de cruzamentos entre as populações resultantes. A avaliação correta de parâmetros genéticos inerentes a este método, assume fundamental importância quando se objetiva utilizá-los em programas de seleção recorrente e/ou na ampliação da base genética do germoplasma disponível.

\subsection{Seleção Recorrente em plantas autógamas}

\subsubsection{Aspectos gerais}

Além da soja, a seleção recorrente tem sido utilizada no melhoramento de diversas culturas autógamas: aveia (KHADR \& FREY, 1965; BRANSON \& FREY, 1989), arroz (RANGEL \& NEVES, 1995), cevada (WEBER et al., 1990) feijão (FOULLOUX \& BANNEROT,1988; DELANEY \& BLISS, 1991a, 1991b), fumo (GUPTON, 1981; TEDFORD \& NIELSEN, 1990) e trigo (MCNEAL et al., 1978; AVEY et al., 1982; LÖFFLER et al., 1983). 
Todos os procedimentos em melhoramento de espécies autopolinizadas, com exceção de seleção massal, envolvem simultânea ou concomitantemente seleção e recombinação. Intuitivamente, seleção recorrente deveria ser um método efetivo de melhoramento destas espécies (FREY, 1976). Por definição, todos os melhoristas usam a seleção recorrente, embora muitos talvez, não saibam disto. Retrocruzamentos, por exemplo, constituem uma técnica de seleção recorrente (FOUILLOUX \& BANNEROT, 1988).

De acordo com PIPER \& FEHR (1987), os programas convencionais de melhoramento podem diferir de métodos de seleção recorrente em vários aspectos. 1) relativamente poucos cruzamentos são utilizados para gerar variabilidade genética; 2) bons parentais usados para cruzamentos em uma geração podem ser usados como parentais em gerações mais tardias; 3) germoplasma desenvolvido fora do programa é rotineiramente introduzido e germoplasma parental é usualmente identificado após extensivos testes.

SILVELA \& DIEZ-BARRA (1985) demonstraram através de modelos matemáticos que, quando considerado apenas um locus, o sistema de seleção recorrente é menos efetivo que sistemas de seleção baseados em endogamia. Quando se considera um modelo para muitos loci, espera-se que a vantagem seletiva da aditividade de um bom recombinante seja explorada mais eficientemente, sob seleção recorrente, que sob seleção convencional. Isto pode ser esperado por obter melhor eficiência quando envolvidos mecanismos de epistasia, que aumentam a vantagem seletiva dos novos recombinantes formados.

Segundo COMPTON (1977), a seleção recorrente pode ser o melhor investimento de tempo e dinheiro, quando considerados a presença de efeitos aditivos e de epistasia de efeitos aditivos $\mathrm{x}$ aditivos. $\mathrm{O}$ mesmo autor 
demonstrou também, um modelo no qual este tipo de epistasia pode ocorrer, fazendo com que resulte em heterose sobre o parental de maior valor.

AVEY et al. (1982), utilizando seleção recorrente para precocidade em trigo, sugeriram que no primeiro ciclo a seleção atuou em genes maiores com alguma ação não aditiva, enquanto que no segundo e terceiro ciclos atuou em genes de menor ação, com efeitos aditivos e aditivos $\mathrm{x}$ aditivos.

Embora muitos trabalhos tenham sido realizados, a seleção recorrente não tem sido adotada extensivamente para o desenvolvimento de cultivares de soja. Segundo FEHR (1987c), não há evidências que a seleção recorrente para produtividade de grãos, providenciará cultivares mais produtivos, que aqueles obtidos com procedimentos de cruzamentos simples, de cultivares e linhagens experimentais altamente produtivos.

\subsubsection{Escolha do material genético inicial}

FEHR (1987b) destaca três pontos básicos para a formação da população básica em programas de seleção recorrente: 1) os parentais devem ter o melhor desempenho possivel para os caracteres a serem melhorados, com maior diversidade genética possível; 2) utilizar o maior número possível de parentais sem comprometer a média dos caracteres de interesse; 3) realizar um número adequado de gerações de intercruzamentos proporcionando a recombinação dos genes dos parentais.

A escolha de parentais com maior diversidade possivel é um requerimento básico para início de um programa de melhoramento, visando o aumento da base genética do germoplasma. VELLO \& PIRES (1992) destacaram a importância da utilização de estratégias para a seleção de 
parentais, nas quais testes de capacidade de combinação, métodos multivariados, de genealogia (coeficiente de parentesco) e marcadores moleculares, fornecem subsídios para uma escolha de genes diversificados, que irão proporcionar uma população de base genética ampla para início da seleção.

Em um programa de seleção recorrente é necessário, inicialmente, desenvolver uma população de intercruzamentos, a qual inclui grande número de parentais e de cruzamentos. Submete-se, então, esta população à seleção de plantas individuais, visando o melhoramento de determinado caráter ou caracteres. As populações superiores oriundas dessas plantas, são utilizadas como parentais para formar uma nova população. O processo se repete, até que o ganho desejado para o caráter seja alcançado. Se o processo de seleção for eficiente, cada nova população será superior à anterior. Linhagens, altamente produtivas e com boas características agronômicas, poderão ser extraídas em qualquer ciclo da população (GILIOLI et al., 1980).

VELLO et al. (1984) citaram a necessidade de estudos de seleção recorrente a longo prazo, na determinação do valor de introduções de germoplasma exótico (PIs) em diversos níveis, para o melhoramento de soja para produtividade.

\subsubsection{Recombinação genética}

A recombinação é um passo necessário para gerar variabilidade genética útil. Para a obtenção de linhagens puras superiores, deve-se associar alelos favoráveis na posição "cis", por intercruzamentos dos genótipos disponíveis, com gerações subseqüentes de autofecundação das populações. Este processo 
natural de endogamia das autógamas irá eliminar a "falsa" variabilidade associada com interações epistáticas "trans". Ele irá revelar, também, um novo tipo de variabilidade associada com interações epistáticas aditivas $\mathrm{x}$ aditivas. $\mathrm{A}$ extensão com que alguns alelos favoráveis podem permanecer ligados a alelos desfavoráveis, podem levar a uma redução na variabilidade genética quando é realizada seleção contra estes alelos. Por isso, torna-se necessário promover elevados níveis de recombinação (FOUILLOUX \& BANNEROT, 1988).

PFEIFFER \& VOGT (1990) encontraram variabilidade para a freqüência de recombinação (FC) entre indivíduos da população de soja AP12, apresentando distribuição normal. Ao que tudo indica, este caráter (FC) aparenta ter controle poligênico na cultura da soja. Efeitos ambientais foram associados a mudanças na freqüência de recombinação (FC) de um determinado grupo de ligação (ln-p2), quando testados em ambientes diferentes, considerando-se também neste caso a época de semeadura (PFEIFFER \& VOGT, 1989).

Apesar dos méritos da seleção recorrente, relativamente pouca pesquisa tem sido feita em soja com a utilização deste método. Uma das dificuldades apontadas é a obtenção de um grande número de intercruzamentos necessários em cada ciclo, aliado à obtenção de um número adequado de sementes para avaliações. Para solucionar este problema tem sido proposto o uso da machoesterilidade, com vários esquemas de aplicação demonstrados por BRIM \& STUBER (1973). Através deste método, diversos caracteres, tais como, tamanho e/ou peso de sementes (TINIUS et al., 1992; MIRANDA, 1994), teor de óleo e ácido oleico no grão (BURTON \& BRIM, 1981; BURTON et al., 1983) e produtividade de grãos (BURTON et al., 1990; WERNER \& WILCOX, 1990), foram avaliados em programas de seleção recorrente. 
A efetividade e a casualização de cruzamentos em soja com o uso de macho-esterilidade, foi considerada por ST. MARTIN \& EHOUNOU (1989) como aceitável. ZHIHONG \& JUNZHENG (1991) demonstraram que um grande número de sementes de cruzamentos naturais pode ser obtido em plantas macho-estéreis de soja, na condição de uso da proporção de dois machos para uma fêmea, não havendo diferenças entre os arranjos alternados ou misturados dos parentais. A afinidade de cruzamentos entre machos e fêmeas foi o fator mais importante para na produção de sementes. Outro fator relevante a ser considerado seriam as diferenças genotípicas na atratividade de vetores de pólen (ERICKSON, 1975).

A proposta do uso de macho-esterilidade para solucionar o problema dos inúmeros intercruzamentos, todavia, tem sido associada a falhas nos testes das populações que estão segregando entre plantas macho-férteis e macho-estéreis. O número de anos por ciclo também pode ser maior para populações mantidas sob este sistema, relativamente às populações desenvolvidas e mantidas por cruzamentos manuais (FEHR \& ORTIZ, 1975).

Alternativas foram propostas por COMPTON (1968), envolvendo testes de produtividade, seleção e posterior intercruzamentos (ex. dialelo incompleto) de um grupo mais produtivo de linhagens, de maneira a se evitar o uso de cruzamentos extensivos. KENWORTHY \& BRIM (1979) sugeriram a inclusão de uma geração de autofecundação produzindo, assim, um número adequado de sementes para avaliação, aliado ao uso de parcelas em covas, que proporcionou um teste funcional acomodando grande número de populações com um número mínimo de sementes. A eficiência relativa das parcelas em covas para teste de grande número de genótipos em uma área de campo proporcionalmente pequena foi comprovada por CARNIELLI \& VELLO (1992). 
O número de intercruzamentos por ciclo tem sido objeto de estudo por diversos autores na cultura da soja. PIPER \& FEHR (1987), comparando quatro estratégias de seleção recorrente e uma de melhoramento convencional, concluíram que múltiplas gerações de intercruzamentos não proporcionaram ganhos elevados em comparação com o método convencional. Estes resultados corroboram com os obtidos por GUMMARAES \& FEHR (1989), que encontraram melhores resultados, na obtenção de linhagens de alta produtividade, com apenas uma geração de intercruzamentos em comparação a três gerações.

\subsubsection{Manutenção da variabilidade genética durante a seleção}

A prática de cruzamentos múltiplos aumenta a probabilidade de combinações gênicas desejáveis nas populações segregantes, aumentando a freqüência de genes favoráveis, sem reduzir significativamente a variabilidade através da prática de seleção recorrente. Este procedimento, permite desenvolver uma nova população com alta freqüência de plantas superiores (GILIOLI et al., 1980; FEHR, 1987b).

Devido à presença de alguns alelos favoráveis que ainda permanecerem ligados a alelos desfavoráveis, possíveis perdas de genes favoráveis podem ocorrer com a seleção. FOUILLOUX \& BANNEROT (1988), sugeriram a redução da intensidade de seleção como única maneira de minimizar perdas nestes casos, embora o custo de menores ganhos por ciclo de seleção seja incompatível com as metas econômicas do programa.

Uma maneira de contornar este problema foi sugerida por GALLAIS (1977), pela qual a variabilidade genética poderia ser preservada em uma 
população básica submetida a baixa intensidade de seleção. Concomitantemente, genótipos obtidos no final de um ciclo de seleção nesta população básica poderiam ser utilizados como fonte de desenvolvimento de cultivares, ocasião em que uma forte intensidade de seleção poderia ser exercida, inicialmente para eliminar defeitos e, depois, para selecionar linhagens com as características desejadas.

Uma questão freqüentemente levantada por melhoristas é sobre a necessidade da opção entre um maior número de cruzamentos ou aumentar o tamanho das populações segregantes, de maneira a evitar perdas com a deriva genética.

Segundo FOUILLOUX \& BANNEROT (1988), conclusões baseadas em estudos com outros modelos de cruzamentos, sugerem que é necessário gerar o máximo número de estruturas heterozigóticas, providenciando que o número de linhagens de populações por estrutura seja superior a dez. Obviamente então seria preferível optar por um número maior de cruzamentos, sendo que o modelo piramidal seria a melhor solução. Este método ameniza a conseqüência de erros feitos durante a escolha de parentais para início de um novo ciclo de seleção.

BRIM \& BURTON (1979) alcançaram progressos significativos com seleção recorrente em soja; neste trabalho, o uso de um tamanho efetivo populacional reduzido e de um número relativamente pequeno de linhagens testadas por ciclo, tiveram pouco efeito no aumento do teor protéico nas sementes. Em um programa simulado de seleção recorrente iniciado com 2, 4, 8 , ou 16 parentais, utilizando-se $1,2,4$ ou 8 cruzamentos, a variabilidade genética não exauriu rapidamente, mesmo com os menores números de parentais (WEBER et al., 1990). 
PEREIRA (1980), considerando um modelo aditivo, concluiu que os valores mínimos do tamanho efetivo de uma população para se garantir ganhos por seleção a médio e longo prazo, sem perdas consideráveis da variabilidade genética, depende da estrutura da população e deve apresentar valores mínimos de aproximadamente: $\mathrm{N}_{\mathrm{e}}=40$, para uma população de base genética ampla e freqüência alélica intermediária, $N_{e}=25$, para uma população mais melhorada e $\mathrm{N}_{\mathrm{e}}=50$ para uma população pouco melhorada.

\subsubsection{Herança do tempo para florescimento e maturidade, altura da planta, valor agronômico e produtividade de grãos em soja.}

Em soja, as heranças quantitativas do tempo para o florescimento, tempo para a maturidade e altura da planta, são aceitas como regra geral. Contudo, algumas pesquisas também têm detectado genes principais com efeitos pronunciados sobre estes caracteres. Já a herança da produtividade de grãos tem sido relacionada como sendo só de natureza quantitativa (PACOVA, 1992).

A complexidade do caráter valor agronômico, aliada à subjetividade com que é feita sua avaliação, proporcionam muitas vezes grandes desvios padrões de suas estimativas; de fato, isto ocorre principalmente devido à utilização de um escore, baseado em uma única nota que reúne vários caracteres considerados importantes agronomicamente, muitas vezes altamente influenciados pelo ambiente.

A importância do coeficiente de herdabilidade para o melhorista, não se deve unicamente ao fato dele expressar a proporção da variância total que é atribuída ao efeito médio dos genes. O papel principal reside no seu caráter 
preditivo, que exprime a confiança do valor fenotípico como um guia para o valor genético (FALCONER, 1987).

BRIM (1973) e BURTON (1987), relataram coeficientes de herdabilidade para vários caracteres, cujos limites são apresentados a seguir, estando entre parênteses os valores encontrados na maioria dos trabalhos: 3 a $58 \%$ (33 a $58 \%$ ) para produtividade de grãos, 65 a $91 \%$ (75 a $90 \%$ ) para altura da planta e número de dias para florescimento e 75 a $94 \%$ (75 a $91 \%$ ) para o número de dias para a maturidade.

Após este período, herdabilidades no sentido amplo $\left(\mathrm{h}_{\mathrm{A}}^{2}\right)$ e no sentido restrito $\left(\mathrm{h}_{\mathrm{R}}^{2}\right)$, obtidas por vários autores, foram sumarizadas por PACOVA (1992), com estimativas descritas a seguir (incluindo resultados obtidos por este autor):

\begin{tabular}{lcc}
\hline \multicolumn{1}{c}{ Caracteres } & $\mathrm{h}_{\mathrm{A}}{ }_{\mathrm{A}}(\%)$ & $\mathrm{h}_{\mathrm{R}}{ }_{\mathrm{R}}(\%)$ \\
\hline Número de Dias para o Florescimento (NDF) & 49 a 99,7 & 23 a 96,9 \\
Número de Dias para a Maturidade (NDM) & 42 a 99,2 & 0 a 92,5 \\
Altura da Planta no Florescimento (APF) & 80 a 120,0 & 11 a 88,0 \\
Altura da Planta na Maturidade (APM) & 31 a 92,0 & 0 a 93,6 \\
Valor Agronômico (VA) & 34 a 80,0 & 11 a 29,0 \\
Produtividade de Grãos (PG) & 22 a 95,0 & 11 a 58,2 \\
\hline
\end{tabular}

A herdabilidade têm sido utilizada como fonte de informação sobre a variabilidade útil disponível através de gerações e ciclos nos programas de seleção recorrente em soja. FEHR \& ORTIZ (1975) estimaram uma herdabilidade elevada (69 \%) para produtividade de grãos praticando seleção recorrente com teste de produtividade em $\mathrm{S}_{\mathrm{I}}$. 
Utilizando populações $\mathrm{S}_{0}$ de plantas individuais espaçadas e machoestéreis $\left(\mathrm{ms}_{2} \mathrm{~ms}_{2}\right)$, WILCOX \& MAY (1986) estimaram herdabilidades no sentido restrito para produtividade de grãos, da ordem de 55 a $70 \%$. À partir da população obtida neste trabalho, WERNER \& WILCOX (1990) estimaram herdabilidades bem menores $(0,6 \pm 0,4 \%)$, para três ciclos de seleção posteriores, utilizando também seleção em plantas individuais $\mathrm{S}_{0}$.

BURTON et al. (1990) encontraram herdabilidades para produtividade de grãos, decrescendo de 62 até $43 \%$ ao longo de quatro ciclos; em outra população a herdabilidade variou de 18 a $32 \%$. Após cinco ciclos de seleção recorrente, para produtividade de grãos, ROSE et al. (1992), estimaram uma herdabilidade média de $64 \%$, inflacionada pela enorme variação genética da população básica, pelos efeitos da segregação para resistência a Phytophtora, podridão do colmo e deiscência das vagens.

Trabalhando com a geração $F_{2}$ de um dialelo entre parentais semi-tardios em soja, NASS (1989) obteve herdabilidades no sentido amplo de 0,81 (NDF), 0,40 (APF), 0,79 (NDM), 0,59 (APM), 0,41 (VA) e 0,43 (PG), sendo a semeadura do experimento realizad a no outono/inverno.

\subsubsection{Correlações entre caracteres}

Segundo JOHNSON et al. (1955), estimativas de correlações genotípicas e fenotípicas são úteis no planejamento e avaliação de programas de melhoramento. O conhecimento de correlações existentes entre caracteres importantes pode facilitar a interpretação de resultados prontamente obtidos e providenciar uma base para planejar programas mais eficientes para o futuro. Além disso, correlações entre caracteres importantes e não importantes podem 
proporcionar indicadores úteis para o melhoramento, selecionando-se para uma resposta indireta.

WEBER \& MOORTHY (1952) e JOHNSON et al. (1955), estimaram correlações genotípicas positivas entre florescimento e maturidade, produtividade e maturidade, produtividade e altura da planta, sendo que no geral, as correlações genotípicas foram maiores que as fenotípicas, fato este que parece ser bastante comum na cultura da soja. Correlações entre caracteres medidos com base em parcelas foram em geral mais consistentes que as baseadas em plantas individuais. $\mathrm{O}$ mesmo resultado em relação a plantas individuais foi avaliado por BRAVO et al. (1980), trabalhando com médias de populações.

PACOVA (1992) relatou correlações genotípicas $\left(\mathrm{r}_{\mathrm{G}}\right)$ obtidas por vários autores, sendo também sumarizadas a seguir:

\begin{tabular}{lc}
\hline \multicolumn{1}{c}{ Caracteres } & $\mathrm{r}_{\mathrm{G}}$ \\
\hline Tempo de florescimento x Produtividade de Grãos & $-0,16$ a 0,87 \\
Florescimento x Maturidade & 0,30 a 0,90 \\
Florescimento e Altura no Florescimento & 0,89 a 0,99 \\
Maturidade e Altura na Maturidade & 0,32 a 0,90 \\
\hline
\end{tabular}

Assim como para tempo para florescimento, as correlações fenotípicas entre produtividade de grãos e número de dias para a maturidade, apresentaram ampla gama de valores, oscilando de -0,86 a 1,05 (ANAND \& TORRIE, 1963; KWON \& TORRIE, 1964; SCHAPAUGH JR. \& WILCOX, 1980; NELSON, 1986; PACOVA, 1992). 
Nas condições de cultivo de outono/inverno e para baixas latitudes, destacam-se a importância de correlações entre número de dias para o florescimento e altura da planta no florescimento, com produtividade de grãos (FARIAS NETO, 1987; NASS, 1989; PACOVA, 1992).

Estimativas entre correlações genotípicas de valor agronômico e produtividade de grãos foram obtidas por FREIRE FILHO (1988) e por PACOVA (1992), variando de 0,13 a 0,98 para experimento em covas. Valores negativos $(-0,49$ e $-0,02)$ foram obtidos com base na parcela, respectivamente para dez parentais e 45 cruzamentos dialélicos (FREIRE FILHO, 1988).

HANSON et al. (1962) relacionaram o mérito da discriminação visual com a propriedade de descartar as linhagens pouco produtivas, as quais deveriam ser facilmente identificadas pela escala visual. Uma menor efetividade da seleção visual foi verificada por BYTH et al. (1969) com a redução da média de um ambiente sujeito a estresse. Seleção entre plantas na geração $F_{2}$ também foi menos eficiente que entre linhagens homogêneas. WILCOX \& SCHAPAUGH (1980) não encontraram ganhos na média de populações, a partir de seleção visual entre plantas de $F_{2}$ até $F_{4}$.

A capacidade de discriminação visual de oito entre dez melhores linhagens, de um total de 50, foi obtida por GARLAND \& FEHR (1981), utilizando parcelas em covas e fileiras. HELMS et al. (1995), avaliando a seleção visual somente para produtividade, encontraram respostas positivas em dois de um total de três melhoristas, que diferiram na sua habilidade de identificar linhagens altamente produtivas de cruzamentos biparentais adaptados x não-adaptados.

Diversos trabalhos de seleção recorrente têm relacionado a seleção para produtividade com um aumento, muitas vezes inaceitável, no ciclo das plantas 
de soja (FEHR, 1974; SUMARNO \& FEHR, 1982; WERNER \& WILCOX, 1990), demonstrando a necessidade de se avaliar corretamente estas associações e adequar, caso necessário, os parâmetros de seleção e/ou técnicas experimentais, obtendo-se assim resultados mais satisfatórios na sintese de populações superiores.

Embora a associação positiva de maturidade tardia com produtividade ocorra na maioria dos trabalhos, a presença de valores negativos deve ser interpretada como de importância na seleção indireta para obtenção de ganhos na produtividade de grãos. Este fato torna-se ainda mais relevante, principalmente quando o objetivo for o cultivo de outono/inverno (semeaduras tardias), pois o desempenho de genótipos muito tardios nestas condições fica condicionado a possíveis limitações hídricas, fotoperiódicas e de temperatura, durante boa parte do período vegetativo e no período reprodutivo.

\subsubsection{Seleção em populações segregantes}

O ganho genético em um programa de seleção recorrente é função da efetividade dos procedimentos usados para as três fases operacionais de cada ciclo: (i) obtenção de indivíduos ou famílias para avaliação; (ii) avaliação destes indivíduos ou famílias com seleção de parentais e (iii) intercruzamentos dos parentais selecionados para formar a população básica para o próximo ciclo de seleção (PIPER \& FEHR, 1987). A busca pela identificação de populações superiores em gerações precoces tem sido fonte de vários trabalhos em soja, com a proposição de melhorar a eficiência de programas de melhoramento (TOLEDO, 1989). 
BRIM \& COCKERHAM (1961) relataram a variância aditiva como componente principal da variância herdável para maturidade, altura da planta e produtividade, sendo que a variância da epistasia aditiva $x$ aditiva foi comparativamente pequena. A importância de valores elevados da variância aditiva reside no fato que nos cruzamentos em que isto acontece, as médias das gerações tendem a permanecer constantes, favorecendo a seleção nas gerações precoces. Estes resultados foram contrários aos obtidos por HANSON et al. (1967) que estimaram efeitos da variância epistática aditiva $\mathrm{x}$ aditiva como sendo maior que $50 \%$ da variância genética total para produtividade e maturidade e cerca de $20 \%$ para altura da planta.

LEFFEL \& HANSON (1961) reportaram correlação de magnitude média $(r=0,48)$ entre a produtividade de plantas $F_{1}$ e a produtividade das melhores $(p=20 \%)$ linhagens $F_{3}$ de 45 cruzamentos de soja. Métodos de seleção de familias em gerações precoces, foram superiores aos métodos da população (bulk) e genealógico (pedigree) na identificação de linhagens produtivas (VOIGT \& WEBER, 1960; LUEDDERS et al., 1973), não encontraram diferenças significativas de produtividade entre as linhagens selecionadas pelos métodos de seleção em gerações precoces, população e genealógico.

BOERMA \& COOPER (1972), usando um teste precoce modificado em soja, identificaram linhagens homozigóticas superiores derivadas de plantas $\mathrm{F}_{2}$ selecionadas para produtividade de grãos. Em outro trabalho, BOERMA \& COOPER (1975), obtiveram um aumento na maturidade com a seleção precoce de linhagens de alta produtividade em relação aos métodos de SSD e genealógico, não havendo porém diferenças entre métodos na identificação de linhagens com alta produtividade. 
A seleção em gerações precoces é ainda mais importante na seleção recorrente, uma vez que o ganho genético depende, entre outros fatores, do número de anos por ciclo de seleção. Nos programas de seleção recorrente é muito difícil reduzir a fase de intercnuzamentos, a qual depende do número de cruzamentos sucessivos, que dependem por sua vez, do número efetivo de recombinações. Como a intensidade de seleção é relativamente baixa, as avaliações não necessitam de rigorosa precisão, de maneira que o principal obstáculo, seria a obtenção de um número satisfatório de sementes para seleção em gerações precoces (FOUILLOUX \& BANNEROT, 1988).

Segundo LEFFEL \& HANSON (1961), as falhas para reconhecer populações altamente produtivas em gerações precoces em soja, devem-se a: (1) interações genótipos $\mathrm{x}$ ambientes; (2) testes inadequados no tempo e espaço; (3) heterose devido a efeitos epistáticos ou de dominância, os quais não são verificados ou mantidos em linhagens puras; (4) heterozigosidade e heterogeneidade de genótipos dentro de populações e (5) competição entre parcelas. Os autores sugerem que das três gerações iniciais avaliadas, apenas a geração $F_{1}$ não seria útil para prever $o$ valor de cruzamentos testados adequadamente no tempo e espaço.

A importância de interações genótipos $\mathrm{x}$ ambientes e a consistência de avaliações no tempo e espaço, foi discutida por ALLIPRANDINI et al. (1994) para três grupos de maturação de soja em 25 ambientes no Estado do Paraná. Os resultados evidenciaram a importância da correta alocação de recursos em programas de melhoramento, sendo que com uma avaliação da magnitude de efeitos ambientais, pode-se reduzir o número de anos ou de locais de testes, economizando-se tempo e dinheiro, sem redução do ganho genético por ciclo.

GUIMARAES \& FEHR (1989) encontraram maior número de linhagens de alta produtividade com estratégias de seleção recorrente em dois estágios de 
testes de produtividade, do que com um único estágio. Os autores indicaram que a estratégia apropriada de seleção recorrente para produtividade em soja, poderia envolver dois estágios de testes com repetição para identificar linhagens superiores, e uma geração de intercruzamentos entre as linhagens selecionadas para formar uma nova população. Estes resultados concordam com os obtidos por PIPER \& FEHR (1987). Por sua vez, RAMALHO et al. (1993) indicaram para a cultura do feijoeiro duas ou três gerações de avaliação em cada ciclo.

Ao que tudo indica, o uso de testes em gerações precoces parece ter sido adotado na maioria dos programas de seleção recorrente em soja. WERNER \& WILCOX (1990) avaliaram a efetividade de seleção recorrente, comparando três critérios de seleção em plantas individuais $\mathrm{S}_{0}$. A seleção para produtividade "per-se" aumentou a produção (2,8 $\pm 2,2$ g/planta), mas com inaceitável aumento na maturidade $(3,9 \pm 0,6$ dias/ciclo); a seleção baseada em um índice de produtividade com regressão para maturidade foi efetiva $(5,7 \pm$ $2,4 \mathrm{~g} /$ planta $),$ sem causar grandes alterações na maturidade $(0,8 \pm 0,5$ dias/ciclo); a seleção baseada em índice de colheita aparente foi ineficaz.

FEHR \& ORTIZ (1975) demonstraram teoricamente que testes aplicados na geração $S_{1}$ proporcionariam maior ganho genético por ano, que avaliações em estágios mais avançados de endogamia. Os autores também compararam o ganho esperado com testes de progênies em $\mathrm{S}_{1}$, com e sem macho-esterilidade, avaliações em $\mathrm{S}_{4}$ sem macho-esterilidade e seleção de famílias de meio-irmãos com macho-esterilidade. Os maiores ganhos foram obtidos com testes em $\mathrm{S}_{1}$. Houve maior variabilidade em $\mathrm{S}_{4}$ que em $\mathrm{S}_{1}$ devido à maior endogamia.

Segundo COCKERHAM (1983), SOUZA JÚNIOR (1989) e SOUZA \& RAMALHO (1985), a covariância genética entre a unidade de seleção em $\mathrm{S}_{1}$ com genótipos homozigóticos selecionados a partir de seleção recorrente em 
autógamas, corresponde a: $\operatorname{Cov}\left(\mathrm{S}_{1}, \mathrm{~S}_{\infty}\right)=\sigma_{\mathrm{A}}^{2}+1,5 \mathrm{D}_{1}+0,25 \mathrm{D}_{2}$. Em S2, este valor passa a ser: $\operatorname{Cov}\left(S_{2}, S_{\infty}\right)=1,5 \sigma_{A}^{2}+2,75 D_{1}+0,63 D_{2}$, indicando que a seleção em $S_{2}$ poderia ser mais vantajosa. Porém, esta vantagem poderia ser anulada em populações pouco melhoradas (freqüência de alelos favoráveis menor que 0,5 e dominância para aumentar a expressão do caráter), pois $D_{1}$ ( covariância entre os efeitos aditivos e os efeitos de dominância dos alelos nos homozigotos) pode apresentar valores negativos.

Com a utilização de macho-esterilidade para praticar seleção recorrente em $S_{1}$, BURTON et al. (1990), encontraram ganhos de 2,1 \% (76,6 $\pm 23,2$ $\mathrm{Kg} / \mathrm{ha}$ ) ao ano para produtividade de grãos, 5,9 \% para altura da planta, e redução de 8,9 \% no acamamento. Os ganhos obtidos com uma outra população de soja não foram significativos. Este sucesso diferencial entre populações, foi explicado devido às diferenças na variabilidade genética e herdabilidades.

A macho-esterilidade também facilitou a prática eficiente de dois ciclos de seleção recorrente divergente para produtividade de grãos e teor de óleo nas sementes em população brasileira de soja (MIRANDA, 1994).

Ganhos substanciais foram obtidos por KENWORTHY \& BRIM (1979), que reportaram um aumento na produtividade com avaliação de linhagens $S_{1}$ de $134 \mathrm{Kg} / \mathrm{ha} /$ ciclo, para três ciclos de seleção recorrente em soja.

A resistência à deficiência de ferro em soja foi avaliada por PROHASKA \& FEHR (1981), com seleção em $\mathrm{S}_{1}$, indicando eficiência do método para este caráter. WALKER \& SCHMITTHENNER (1984), indicaram a avaliação de linhagens $S_{1}$ como um método efetivo no melhoramento de populações para tolerância à Phytophthora megasperma Drechs. f. sp. glycinea Kuan e Erwin. 
A partir de 17 linhagens escolhidas pelo potencial produtivo em dialelo, ROSE et al. (1992) intercruzaram $F_{l} S$ em pares por mais duas gerações, obtendo híbridos de oito parentais. Após duas gerações de autofecundação para formar a população básica, utilizou-se o critério de seleção para produtividade em linhagens $S_{1}$ para cada ciclo, com aproximadamente $10 \%$ de seleção. A média de todas as linhagens testadas e selecionadas, aumentou de 17 e $54 \%$ respectivamente após cinco ciclos de seleção, em comparação com "Davis".

Apesar da efetividade da seleção recorrente com testes em $S_{1}$, problemas com acréscimo excessivo no número de dias para a maturidade das plantas das populações têm sido relatados, quando a seleção é feita para alta produtividade (FEHR, 1974) e para elevados teores de proteína (MILLER \& FEHR, 1979). De acordo com SUMARNO \& FEHR (1982), o problema parece estar associado, em parte, com a dificuldade de determinar a maturidade apropriada de linhagens segregando para o caráter dentro das fileiras. Uma possível solução seria conduzir a seleção recorrente utilizando-se linhagens em níveis mais avançados de endogamia.

HANSON (1992) estudou a efetividade da seleção recorrente fenotípica para modificar o período reprodutivo em soja, utilizando a geração $\mathrm{S}_{2}$ para seleção. Seleção divergente para o caráter gerou uma diferença de dez dias, com efeito mínimo no potencial produtivo. Associações positivas entre período reprodutivo e produtividade foram conflitantes em ambientes contrastantes, sendo que esta vantagem não se expressou em ambientes com deficiência hídrica no período reprodutivo. $\mathrm{O}$ autor conclui que a soja tem capacidade de obter produtividades independentemente de alterações na duração do período reprodutivo, reafirmando a inconsistência de estudos realizados neste sentido.

Com o objetivo de avaliar a resposta da seleção recorrente para produtividade de grãos em linhagens derivadas de $F_{4}$ ou $F_{5}$, SUMARNO \& 
FEHR (1982) encontraram respostas semelhantes à seleção de parentais individuais e em um composto dos parentais, considerando-se os ciclos de 0 a 3 em três grupos de maturação. O maior ganho foi obtido para materiais precoces $(120 \pm 10 \mathrm{Kg} / \mathrm{ha})$ e menor para tardios $(24 \pm 9 \mathrm{Kg} / \mathrm{ha})$ e médios $(-14$ $\pm 8 \mathrm{Kg} / \mathrm{ha}$ ). Não houve alterações consistentes na maturidade, acamamento, altura, peso de sementes, proteína ou óleo, causadas pela seleção para produtividade. 


\section{MATERIAL E MÉTODOS}

\subsection{Obtenção dos cruzamentos quádruplos e da geração $F_{1[4]}$}

O sistema de cruzamentos quádruplos iniciou-se em 1989, na Escola Superior de Agricultura "Luiz de Queiroz" em Piracicaba - SP, com a obtenção de dois dialelos: o primeiro envolveu dez parentais do ciclo semi-tardio e o segundo dez parentais do ciclo tardio (VELLO, 1992).

A escolha dos 20 parentais baseou-se na divergência existente entre os mesmos (VELLO et al. 1988), na capacidade de combinação e na produtividade "per-se" (FARIAS NETO, 1987; NASS, 1989). Maiores informações sobre os genótipos utilizados como parentais deste trabalho foram fornecidas por ALMEIDA et al. (1991a); ALMEIDA et al. (1991b); YORINORI et al. (1993) e EMBRAPA (1994; 1995), constando nos Apêndices 1 até 5.

Em 1990 foram realizados cruzamentos aos pares entre os 45 cruzamentos simples dos dialelos, conforme demonstra o Apêndice 6 e a Figura 1, resultando em 45 cruzamentos quádruplos.

Estas duas gerações de recombinação foram obtidas através de cruzamentos manuais realizados em telado, com teto de telhas plásticas translúcidas e laterais com tela sombrite para passagem de 50\% de luz. Estas instalações permitem na região de Piracicaba ( $23^{\circ}$ de latitude e 534 metros de 
altitude), a realização de cruzamentos diários, no período de 10 às 16 horas, durante os meses de setembro a abril, sempre que a umidade relativa do ar não for muito elevada.

Não foi realizada a emasculação das flores para os cruzamentos, sendo o sucesso detectado pela presença de genes marcadores presentes nos parentais e nas plantas $F_{1}$, envolvendo cor do hipocótilo, das flores, da pubescência, das vagens, das sementes (tegumento, hilo e cotilédones), hábito de crescimento e ciclo. Quando não foi possível separar cruzamentos e autofecundações, as sementes das plantas $F_{1}$ foram mantidas separadas para exame da segregação na geração $\mathrm{F}_{2}$, principalmente pela comparação do ciclo destas plantas com o ciclo dos parentais. Se a dúvida persistiu, toda a progênie $F_{2}$ derivada da planta $F_{1}$ foi eliminada. A geração $F_{1[4]}$ proveniente dos cruzamentos quádruplos (segunda recombinação; considerada neste trabalho como sendo semelhante a uma população $S_{0}$ não endogâmica), foi mantida em telado durante o ano agrícola de 1991/92 em Piracicaba, sendo o número de sementes viáveis obtidas por cruzamento apresentados no Apêndice 6. Para diferenciar uma geração proveniente de um cruzamento quádruplo, da resultante de um cruzamento simples, adotou-se um índice [4] localizado após o índice da geração em questão; ex: $F_{n[4]}$.

\subsection{Geração $F_{2[4]}$}

Alguns cruzamentos apresentaram sementes $\mathrm{F}_{2[4]}$ com germinação e vigor de plântula reduzidos, fato que obrigou a utilização de semeadura em papel toalha em germinadores a $25^{\circ} \mathrm{C}$, na data de 4/12/92. As sementes dos parentais (incluindo as testemunhas) e progênies, foram tratadas com TECTO 
$100^{\circledast}$ (Thiabendazol), utilizando-se $100 \mathrm{~g} / 100 \mathrm{Kg}$ de sementes. O transplantio para copos, com um misto de terra e adubo orgânico, no telado foi realizado no dia 07/12/92, sendo levados para o campo em 14/12/92 na área experimental do Departamento de Genética, ESALQ/USP, em solo classificado como terra roxa estruturada eutrófica.

O delineamento utilizado foi o de blocos ao acaso, com quatro repetições das 45 populações (Apêndice 6) e mais quatro testemunhas: Cristalina, EMGOPA-301, IAC-8 e OCEPAR-9 (SS-1), totalizando 49 tratamentos. A parcela experimental constituiu-se de três fileiras de quatro plantas. sendo o espaçamento utilizado de $80 \mathrm{~cm} \times 80 \mathrm{~cm}$ entre plantas (Figuras 8 e 9). Cada população foi inicialmente representada por 48 plantas eqüitativamente provindas de cada planta $\mathrm{F}_{1[4]}$, sempre que possível.

Ao lado do primeiro experimento instalou-se um segundo experimento com os 20 parentais em blocos ao acaso com duas repetições. Neste caso, a parcela experimental, constituiu-se de seis plantas individuais ( 2 fileiras com 3 plantas), com espaçamento de $80 \mathrm{~cm} \mathrm{x} 80 \mathrm{~cm}$.

Para adubação foi utilizada uma quantidade de $250 \mathrm{Kg} / \mathrm{ha}$ da fórmula 0 20-20, com inoculação por Bradyrhizobium japonicum, realizada no sulco de plantio. Após o transplantio das mudas efetuaram-se irrigações, evitando-se, assim, maiores falhas. Cada planta foi amarrada em estacas de bambu (Bambusa spp.), para prevenir o acamamento e quebramento dos ramos mais baixos (WERNER \& WILCOX, 1990; Figura 9) e devidamente identificada por uma etiqueta plástica, que a acompanhou até a debulha das vagens. $\mathrm{O}$ controle de pragas e ervas daninhas foi realizado com o uso de inseticidas e herbicidas. 


\subsection{Geração $F_{3: 2[4]}$}

$\mathrm{O}$ avanço a partir da geração $\mathrm{F}_{2[4]}$ foi realizado pelo método da descendência de cova única desbastada (SHDT: Single Hill Descent Thinned; VELLO, 1992). Por este método, as sementes de cada planta $F_{2[4]}$ foram colhidas separadamente e semeadas em covas, utilizando-se 15 sementes $F_{3: 2[4]}$ (derivadas de uma mesma planta $\mathrm{F}_{2[4]}$ ) por cova. Quando a maioria das plantas da cova apresentaram a primeira folha trifoliada (estádio V2), foi feito um desbaste com o auxílio de uma tesoura, deixando-se uma única planta $\mathrm{F}_{3: 2[4]}$ na cova; as sementes remanescentes $F_{3: 2[4]}$ foram mantidas como reserva na câmara-seca. As plantas foram novamente estaqueadas e identificadas (Figura 9).

O experimento com as populações $F_{3: 2[4]}$ foi conduzido em Maracaí - SP ( $23^{\circ}$ de latitude e $450 \mathrm{~m}$ de altitude), na estação experimental da Cooperativa Agrícola Mista da Colônia Riograndense, no ano agrícola 1993/94, em latossolo roxo eutrófico (Figura 8). O delineamento experimental, as parcelas e a condução do experimento foram realizados da mesma maneira que para a geração $\mathrm{F}_{2[4]}$, para as 45 populações e mais quatro testemunhas. $\mathrm{O}$ experimento com os 20 parentais, também foi semelhante ao realizado em Piracicaba.

A adubação constou de uma aplicação de $240 \mathrm{Kg} / \mathrm{ha}$ da fórmula 02-2020, não se utilizando inoculante por se tratar de área tradicional de plantio de soja. Neste experimento não foi realizada irrigação para implantação. A semeadura dos dois experimentos (45 populações e 20 parentais) foi realizada na data de $02 / 12 / 93$.

Nas duas gerações avaliadas anotou-se dados de cada planta referentes aos seguintes caracteres: 
NDF: Número de Dias para o Florescimento; efetuado pela contagem (dias) a partir da data de semeadura até a data da abertura da primeira flor (R1 da escala de FEHR \& CAVINESS, 1977);

APF: Altura da Planta $(\mathrm{cm})$ no Florescimento; efetuado pela medida desde a base da planta (no solo) até o ápice da haste principal;

CF: Cor da Flor (R: roxa ou B: branca);

NDM: Número de Dias para a Maturidade; efetuado pela contagem (dias) desde a data da semeadura até a data em que a planta apresentava 95\% das vagens maduras (R8 da escala de FEHR \& CAVINESS, 1977);

APM: Altura da Planta na Maturidade; efetuada pela medida desde a base da planta até o ápice da haste principal;

CV: Cor das Vagens (Creme, Marrom ou Preta);

CP: Cor da Pubescência (Cinza ou Marrom);

VA: Valor Agronômico; avaliado na maturidade, através de uma escala de notas visuais de 1 (péssimo) a 5 (excelente), representativa de um conjunto de caracteres adaptativos; arquitetura da planta, quantidade de vagens cheias, vigor e sanidade da planta, debulha prematura das vagens, acamamento e retenção foliar;

PG: Produtividade de grãos (g/planta); efetuada através do peso dos grãos, após a debulha das plantas colhidas e a secagem natural (ambiente do laboratório) dos grãos. 


\subsection{Análise dos dados}

A análise dos dados foi realizada segundo as metodologias utilizadas e descritas detalhadamente por PACOVA (1992), sendo utilizado o programa SAS (SAS INSTITUTE INC., 1989) e SAEG, desenvolvido pela Universidade Federal de Viçosa.

\subsubsection{Análise individual dos parentais e populações em cada geração}

A partir dos dados obtidos, calculou-se para cada parental e cada população $F_{2[4]}$ e $F_{3: 2[4]}$, a média, as variâncias fenotípica, ambiental e genotípica, a herdabilidade no sentido amplo, e a razão entre os coeficientes de variação genética e variação ambiental.

Para o cálculo da média, estimou-se a média aritmética com todos os valores individuais $(\mathrm{i}=1, \ldots, \mathrm{n}$, com $\mathrm{n}$ máximo de 48 covas (plantas individuais). A variância fenotípica $\left(\sigma^{2} \mathrm{dF}_{2[4]}\right.$ e $\left.\sigma^{2} \mathrm{dF}_{3: 2[4]}\right)$ dentro de parcelas, foi calculada, ponderando-se o número de plantas por parcela, $(\mathrm{i}=1, \ldots, \mathrm{n}$, com $\mathrm{n}$ máximo de 12 covas) avaliadas em cada repetição.

A herdabilidade no sentido amplo, foi estimada segundo MAHMUD \& KRAMER (1951), para as gerações $F_{2[4]}$ e $F_{3: 2[4]}$ onde:

$$
h_{a}^{2}=\frac{\sigma^{2} G d F_{x}}{\sigma_{F d F_{x}}^{2}}=\frac{\sigma^{2} F d F_{x}-\sigma_{e}^{2}}{\sigma_{F d F_{x}}^{2}}, \text { sendo: }
$$


$\sigma_{\text {GdFx }}^{2}$ : variância genotípica entre covas (dentro de parcelas) de um cruzamento na geração $F_{x}$;

$\sigma_{\text {FdFx }}^{2}$ : variância fenotípica entre covas (dentro de parcelas) de um cruzamento na geração $F_{x}$;

$\sigma_{\mathrm{e}}^{2}$ : variância ambiental, no presente caso, estimada pela média geométrica das variâncias fenotípicas entre covas das quatro testemunhas;

Os valores de $\sigma_{G}^{2}$ e $\sigma_{e}^{2}$ foram utilizados para o cálculo do índice de variação ou razão (b) entre os coeficientes de variação genética (Cvg) e variação ambiental (Cve). Segundo VENCOVSKY (1987), quando b é maior ou igual à unidade, há uma situação muito favorável à seleção para o caráter avaliado, facilitando a discriminação de cruzamentos com médias similares e/ou caracteres mais ou menos alteráveis por seleção, em gerações iniciais.

\subsection{2 - Análises de variância e covariância}

Para cada geração $F_{2[4]}$ e $F_{3: 2[4]}$, estimou-se a média das $n$ covas por repetição das populações, testemunhas e parentais. A seguir, foram realizadas análises de variância para cada caráter e covariância entre pares de caracteres, segundo modelo linear descrito por STEEL \& TORRIE (1980), sendo que as esperanças matemáticas dos quadrados médios e dos produtos médios encontram-se nas Tabelas 1 e 2 , respectivamente.

Uma análise conjunta envolvendo os dois ambientes de avaliação (ano 1 + local 1 vs ano $2+$ local 2 ), foi realizada com os parentais e, também, com as testemunhas, de modo a detectar-se possíveis interações genótipos $\mathrm{x}$ ambientes (Tabela 3). O efeito de genótipos foi considerado como de natureza aleatória, e o efeito de ambientes (local + ano) fixo. A análise de médias foi feita segundo 
o critério de agrupamento de médias de SCOTT \& KNOTT (1974), através do programa SAEG, desenvolvido pela Divisão de Informática da Universidade Federal de Viçosa - MG.

\subsubsection{Correlações entre caracteres}

Com os dados das análises de covariância das gerações estudadas, calculou-se os coeficientes de correlação fenotípica, genotípica e residual, entre seis caracteres, combinados dois a dois, com base em parcelas para as quatro repetições, utilizando-se a aplicação das fórmulas demonstradas a seguir, exraídas com o auxílio das esperanças matemáticas observadas nas Tabelas 1 e 2.

3.4.3.1. Coeficiente de Correlação Fenotípica $\left(\mathrm{r}_{\mathrm{F}}\right)$ :

$$
r_{F}=\frac{\operatorname{Cov}_{F(X, Y)}}{\sqrt{V_{F(X)} \cdot V_{F(Y)}}}, \text { onde: }
$$

$\operatorname{Cov}_{\mathrm{F}(\mathrm{X}, \mathrm{Y})}$ : covariância fenotípica estimada pelo produto médio de tratamentos para o par de caracteres $\mathrm{X}$ e $\mathrm{Y}$.

$V_{F(X)}$ e $V_{F(Y)}$ : variâncias fenotípicas estimadas pelos quadrados médios de tratamentos para os caracteres $\mathrm{X}$ e $\mathrm{Y}$, respectivamente.

3.4.3.2. Coeficiente de Correlação Residual $\left(\mathrm{r}_{\mathrm{E}}\right)$ : 


$$
r_{E}=\frac{\operatorname{Cov}_{E(X, Y)}}{\sqrt{V_{E(X)} \cdot V_{E(Y)}}}, \text { com: }
$$

$\operatorname{Cov}_{\mathrm{E}(\mathrm{X}, \mathrm{Y})}$ : produto médio do resíduo para o par de caracteres $\mathrm{X}$ e $\mathrm{Y}$.

$V_{E(X)}$ e $V_{E(Y)}$ : Quadrados médios do resíduo para os caracteres $X$ e $Y$, respectivamente.

3.4.3.3. Coefíciente de Correlação Genotípica $\left(\mathrm{r}_{\mathrm{G}}\right)$ :

$$
r_{G}=\frac{\operatorname{Cov}_{G(X, Y)}}{\sqrt{V_{G(X)} \cdot V_{G(Y)}}}, \text { sendo: }
$$

$\operatorname{Cov}_{\mathrm{G}(X, Y)}$ : covariância genotípica para o par de caracteres $\mathrm{X}$ e $\mathrm{Y}$; e,

$$
\operatorname{Cov}_{G(X, Y)}=\frac{\operatorname{Cov}_{F(X, Y)}-\operatorname{Cov}_{\mathrm{E}(X, Y)}}{\mathrm{r}}, \mathrm{com}:
$$

$\operatorname{Cov}_{F(X, Y)}$ e $\operatorname{Cov}_{E(X, Y)}$, mencionadas em I e II;

$r=$ número de repetições

$$
\begin{aligned}
& V_{G(X)}=\frac{V_{F(X)}-\mathrm{V}_{\mathrm{E}(X)}}{\mathrm{r}}, \mathrm{e}: \\
& V_{G(Y)}=\frac{V_{F(Y)}-\mathrm{V}_{\mathrm{E}(Y)}}{\mathrm{r}}, \text { sendo: }
\end{aligned}
$$

$V_{G(X)}$ e $\quad V_{G(Y)}$ : variâncias genotípicas para os caracteres $X \quad e \quad Y$, respectivamente;

$\mathrm{V}_{\mathrm{F}(\mathrm{X})}, \mathrm{V}_{\mathrm{E}(\mathrm{X})}$ e $\mathrm{V}_{\mathrm{F}(\mathrm{Y})} \mathrm{V}_{\mathrm{E}(\mathrm{Y})}$, mencionadas em I e II;

$\mathrm{r}=$ número de repetições. 
Para o cálculo da significância das correlações fenotípicas e genotípicas, aplicou-se o teste " $\mathrm{t}$ " (STEEL \& TORRIE, 1980), com $t=\frac{r}{s_{r}}$, onde r é o coeficiente de correlação e $\mathrm{s}_{\mathrm{r}}$, representa o erro padrão do coeficiente de correlação: $\quad s r=\sqrt{\frac{\left(1-r^{2}\right)}{(n-2)}} ;$ testado com (n-2) graus de liberdade, para $\mathrm{n}=\mathrm{k}$ tratamentos conforme sugestão de CECON (1983).

Ainda com os dados de caracteres tomados aos pares, foram calculados os coeficientes fenotípicos de correlação de Pearson para cada uma das populações.

\subsubsection{Análise reunindo as gerações $F_{2[4]}$ e $F_{3: 2[4]}$}

Com os dados das gerações $F_{2[4]}$ e $F_{3: 2[4]}$, preparou-se um novo arquivo relacionando-se cada planta $F_{2[4]}$ com seu respectivo descendente $F_{3: 2[4]}$, permitindo assim avaliar possíveis relações ou associações entre gerações para cada cruzamento quádruplo por correlações de Spearman (SAS INSTITUTE INC., 1989).

A herdabilidade no sentido restrito $\left(\mathrm{h}_{\mathrm{r}}^{2}\right)$ foi calculada, estimando-se o coeficiente de regressão "b" entre gerações e padronizando-se segundo FREY \& HORNER (1957). A seguir, foi realizada uma correção, levando-se em conta a endogamia resultante de $F_{2}$ para $F_{3}$, segundo SMITH \& KINMAN (1965) resultando na seguinte equação:

$$
h^{2} r=(2 / 3) \cdot\left(\sigma F_{2} / \sigma F_{3: 2}\right) \cdot b, \text { onde: }
$$


b é o coeficiente de regressão de $F_{2[4]}$ sobre $F_{3: 2[4]}$ e $\sigma F_{2}$ e $\sigma F_{3: 2}$ correspondem aos desvios-padrão das gerações $F_{2[4]}$ e $F_{3: 2[4]}$, respectivamente.

Deve-se ter em mente que em se tratando de cruzamentos múltiplos, estas estimativas podem estar inflacionadas devido às variâncias de natureza não aditiva (CAHANER \& HILLEL, 1980; BURTON; 1987) e/ou por interações existentes em uma população que supostamente não se encontra em equilíbrio de "Hardy-Weinberg". Considera-se aqui, o valor deste parâmetro, como um auxílio na tentativa de identificação de cruzamentos promissores.

Avaliou-se o ganho genético obtido em $\mathrm{F}_{3: 2[4]}$, subtraindo-se a média de cada população $F_{3: 2[4]}$ em Maracaí - SP (1993/94) sem seleção, da média da nova população $\mathrm{F}_{3: 2[4]}$ proveniente de plantas selecionadas durante a geração $F_{2[4]}$ em Piracicaba - SP (1992/93). Foram considerados os seguintes critérios de seleção:

- PG: Produtividade de grãos

PG > 141 g/planta ("Cristalina": testemunha mais produtiva);

- VA: Valor Agronômico

$\mathrm{VA}=4$ ou 5 (plantas boas ou excelentes)

- NDM: Número de Dias para Maturidade

$\mathrm{NDM} \leq 162$ dias ("BR-11 - Carajás: parental mais tardio).

A altura da planta na maturidade não foi levada em consideração na seleção, por haver um pequeno número de plantas com altura na maturidade menores que $60 \mathrm{~cm}$, sendo as mesmas descartadas por PG ou VA baixo. 
Atribuiu-se peso igual para todos os caracteres e a seguir avaliaram-se algumas combinações entre os mesmos, no sentido de se quantificar quanto a seleção (para cada caráter ou no conjunto) influenciou na produtividade, altura, ciclo e valor agronômico de cada população $F_{3: 2[4] \text {. }}$. 


\section{RESULTADOS E DISCUSSÃO}

\subsection{Análise dos parentais com base em plantas individuais}

As Tabelas 4 a 9 mostram os dados de caracteres relacionados com o número de dias para florescimento (NDF), altura da planta no florescimento ( $\mathrm{APF}$ ), número de dias para a maturidade (NDM), altura da planta na maturidade (APM), valor agronômico (VA) e produtividade de grãos (PG) dos 20 parentais nos anos de 1992/93 em Piracicaba - SP e 1993/94 em Maracaí SP. São fornecidos os valores do número de plantas avaliadas, valores médios, percentuais em relação à média geral, mínimos, máximos, amplitudes e variâncias fenotípicas para cada caráter.

\subsubsection{Florescimento e Maturidade}

$\mathrm{Na}$ Tabela 4, pode-se observar que em média o caráter número de dias para florescimento (NDF), apresentou valores semelhantes nos dois ambientes avaliados, com 68 dias em Piracicaba - SP (92/93) e 67 dias em Maracaí - SP (93/94). Pode-se considerar que este caráter foi pouco influenciado pelo ambiente, resultado este semelhante ao obtido por PACOVA (1992) com soja tipo alimento. 
Do grupo de parentais avaliados, os que floresceram mais precocemente foram IAC-2 em Piracicaba e SS-1 em Maracaí, com 56 dias pós-semeadura. Os parentais com florescimento mais tardio foram Timbira (82 dias) e BR-11 (80 dias) em Piracicaba, sendo que os mesmos totalizaram 79 e 80 dias em Maracaí. Esta amplitude de valores entre os cultivares com florescimento mais precoce e mais tardio, sugere a existência de grande variabilidade entre estes parentais, que por sua vez pode ser explorada em cruzamentos múltiplos.

Um aspecto importante é que alguns destes parentais possuem diferentes genes para período juvenil longo (DESTRO, 1991), proporcionando oportunidades para novas combinações gênicas nas progênies, que poderiam favorecer cultivos de inverno e em baixas latitudes.

As amplitudes e variâncias fenotípicas dentro dos parentais para NDF encontraram-se dentro de limites baixos como seria de esperar, variando entre 0,0 (IAC-2 e IAC-11) e 14,4 (GO79-1039) dias ${ }^{2}$ em Piracicaba e entre 0,0 (SS-1) e 4,43 dias ${ }^{2}$ (BR-11) em Maracaí. Os valores relativamente elevados de variância para NDF em Piracicaba em relação à Maracaí, demonstraram um maior efeito ambiental dentro das parcelas do experimento de Piracicaba ou ainda, que alguns destes parentais podem não estar completamente homogêneos para NDF. Os mesmos resultados foram observados por NASS (1989), também com os parentais IAC-6, IAC-8 e IAC-9 e Cristalina em Piracicaba.

O caráter altura da planta no florescimento (APF, Tabela 5), aparentemente não sofreu grande influência ambiental ao nível de ano/local, pois a APF foi em média 2,13 cm menor em Maracaí no ano agrícola 93/94, que no ano anterior em Piracicaba. No entanto, alguns cultivares apresentaram uma significativa redução (próxima a $10 \mathrm{~cm}$ ) no porte, como pode ser 
observado em EMGOPA-301, IAC-6, IAC-9, Tropical e IAC-2. O cultivar IAC-8 apresentou-se 9,23 cm maior em Maracaí.

Os cultivares com menores valores de APF foram SS-1 em Piracicaba $(47,8 \mathrm{~cm})$ e IAC-2 em Maracaí $(49 \mathrm{~cm})$. As APF mais elevadas foram para Tropical $(88,5 \mathrm{~cm})$ em Piracicaba e GO79-1039 $(82,82 \mathrm{~cm})$ em Maracaí no ano seguinte, suplantando a média em cerca de $30 \%$.

A variabilidade fenotípica entre plantas, para APF, oscilou de 11,21 (Timbira) até $222,87 \mathrm{~cm}^{2}$ (IAC-8) em Piracicaba e de 1,19 (IAC-11) até $191,96 \mathrm{~cm}^{2}$ (IAC-8) em Maracaí. Estes resultados revelam que alguns genótipos, como por exemplo, IAC-8 foram mais influenciados pelo ambiente experimental ou que existe alguma variabilidade dentro do cultivar para esta característica. Valores elevados de variabilidade para APF para IAC-8, também foram observados por MOREIRA (1992).

Os dados referentes ao número de dias para a maturidade (NDM) nos ambientes Piracicaba (92/93) e Maracaí (93/94) podem ser visualizados na Tabela 6. O NDM parece ser bastante influenciado pelo efeito ambiental, havendo em média uma redução de 10 dias no ciclo dos parentais avaliados em Maracaí (135 dias), em relação à Piracicaba (145 dias). Estes valores refletem uma possível redução na disponibilidade hídrica durante o período reprodutivo em Maracaí (Figura 7), agravadas pela presença de uma camada compactada na subsuperfície do solo causada pelo uso intenso e contínuo de grade aradora.

Ainda em relação ao NDM, o cultivar mais precoce nos dois ambientes avaliados foi SS-1 com um ciclo de 131 dias em Piracicaba e 117 dias em Maracaí. Estes resultados corroboram com os obtidos por GOMES (1995) para os parentais semi-tardios; porém, discordam daqueles demonstrados por NASS (1989) e MOREIRA (1992), com semeadura na segunda quinzena de janeiro e início de fevereiro, que obtiveram como mais precoces IAC-4 e Santa Rosa. 
Segundo estes dois autores, isto se deveu provavelmente à presença de período juvenil mais expressivo para o cultivar SS-1 em relação a estes materiais.

O genótipo mais tardio em NDM foi BR-11 (161 dias) em Piracicaba e GO79-1039 (154 dias) em Maracaí. Novamente, a variância fenotípica para NDM foi maior em Piracicaba, com valores extremos entre 0,0 (SS-1, IAC-2) e 73,90 $\operatorname{dias}^{2}$ (BR-11), do que em Maracaí com 0,0 (Cristalina, IAC-4, GO79-1039, Numbaira, Paranagoiana e IAC-2) e 6,50 dias² (BR-11).

Os valores de variância relativamente elevados em Piracicaba, a despeito da maior média, além da maior variabilidade ambiental entre covas já mencionada, deveu-se também ao ataque mais intenso de percevejos, provindos de áreas vizinhas, sendo que estes foram controlados em Maracaí com pulverizações aéreas preventivas em toda a área experimental.

O caráter APM foi bastante afetado pelo ambiente, sendo que em Maracai os parentais foram, em média, $8,18 \mathrm{~cm}$ menores que em Piracicaba no ano anterior. Todos os parentais testados não apresentaram restrições quanto ao porte (APM) das plantas na maturidade (Tabela 7), estando abaixo das médias descritas por ALMEIDA et al. (1991a); houve exceção de IAC-2, que superou em pelo menos $30 \mathrm{~cm}$ o valor descrito por estes autores.

Em média, todos os parentais obtiveram valores de APM maiores que 60 cm, com exceção de Santa Rosa que em Maracaí alcançou 56,36 cm. Em Piracicaba (92/93) o cultivar mais baixo foi IAC-4 com $68,70 \mathrm{~cm}$. Nos dois ambientes, o cultivar com maior porte foi IAC-2, com 102,43 cm em Maracaí (1992/93) e $107 \mathrm{~cm}$ em Piracicaba (1993/94). Devido ao estaqueamento das plantas nas covas, não foi observado o acamamento destes cultivares; em fileiras de bordadura em Maracaí, com plantas não estaqueadas, não ocorreu acamamento em nenhum cultivar. 
A variabilidade para APM, embora um pouco elevada para alguns cultivares, não ultrapassou um coeficiente de variação fenotípica de $25 \%$, com valores da variância oscilando entre 19,40 (IAC-6) e $179,38 \mathrm{~cm}^{2}$ (BR-11) em Piracicaba 92/93 e entre 4,67 (IAC-11) e 294,18 cm² (IAC-8) em Maracaí 93/94.

Valores de variância relativamente elevados de APM foram igualmente observados por NASS (1989), MOREIRA (1992) e GOMES (1995), para os cultivares IAC-8 e EMGOPA-301, confirmando a observação de que alguns destes cultivares são mais influenciados pelo micro-ambiente experimental.

\subsubsection{Valor Agronômico (VA) e Produtividade de Grãos (PG)}

Nas Tabelas 8 e 9, estão representados os dados referentes aos caracteres valor agronômico (VA) e produtividade de grãos (PG) dos 20 parentais avaliados nos anos de 1992/93 em Piracicaba e 1993/94 em Maracaí, com médias de 4,54 e 4,26 para VA, demonstrando pouca influência ambiental quando alterado o ambiente do experimento.

O caráter VA (Tabela 8), apresentou médias entre 4 (IAC-4 e TIMBIRA) e 5 (EMGOPA-301) em Piracicaba e entre 3,44 (IAC-8) e 5 (SS-1) em Maracaí, não demonstrando nenhuma restrição significativa para 0 cultivo destes genótipos nestes dois locais. Cumpre ressaltar que a avaliação do VA é realizada de maneira subjetiva e envolve vários atributos, reunidos em um índice visual, que muitas vezes se expressam diferentemente conforme o ambiente. Valores inferiores para VA, foram observados por NASS (1989), para os parentais do gnupo semi-tardio em cultivo de outono/inverno. 
A variância fenotípica entre covas não ultrapassou um coeficiente de $25 \%$ em relação à média para VA, indicando no geral ser relativamente de baixa amplitude para a grande maioria dos parentais.

O caráter PG (Tabela 9), refletiu maior produtividade média em Piracicaba no ano 1992/93 (112,02 g/planta) que em Maracaí em 1993/94 $(67,03 \mathrm{~g} /$ planta $)$. Atribuiu-se esta maior PG em Piracicaba às condições favoráveis de recursos hídricos (Figura 7). Outro aspecto que pode ter favorecido uma maior produtividade em Piracicaba, foi a adubação orgânica das mudas formadas em recipientes plásticos e a irrigação suplementar nos primeiros dias até a viabilização total (pegamento) das plântulas durante o mês de dezembro.

Pela Figura 7, nota-se também uma melhor distribuição pluviométrica em Piracicaba no mês de janeiro e fevereiro, sendo que neste último, ocorreu a maioria do florescimento dos genótipos. Durante os dois decêndios finais do mês de março e no início de abril, observa-se também um período de maior escassez hídrica em Maracaí, época crítica para a granação dos genótipos, que pode ter afetado este estágio de desenvolvimento.

Segundo MÜLLER (1981) e MACHADO (1981), o acúmulo de substâncias de reserva das sementes, inicia-se dez dias após o florescimento e aumenta em velocidade uma semana depois. Durante as três semanas seguintes, a maior parte da substância seca é acumulada, sendo este o período que mais afeta a PG em soja.

O período seco do segundo decêndio de abril em Piracicaba não foi relevante para o periodo reprodutivo, pois as chuvas ocorridas no primeiro decêndio caíram no final do mesmo. A situação em Maracaí foi sensivelmente agravada pela presença de uma camada de compactação na subsuperfície do 
solo, ocasionada pelo uso intensivo de grade aradora na área de implantação do experimento.

Os cultivares menos produtivos foram: BR-11 (42,73 g/planta) em Piracicaba; Tropical (39,96 g/planta) e BR-11 (46,62 g/planta) em Maracaí. Os cultivares com maior PG foram Cristalina e EMGOPA-301, com médias de 155,57 e 139,11 g/planta em Piracicaba e 100,48 e 89,84 g/planta em Maracaí, superando a média geral em mais de $25 \%$. O cultivar BR-11 revelou-se pouco adaptado ao cultivo nos locais de Piracicaba e Maracaí, por apresentar baixa PG nos dois ambientes. Estes valores discordam parcialmente dos obtidos por NASS (1989) e por MOREIRA (1992) no outono/inverno com genótipos semitardios, que obtiveram os melhores resultados com o cultivar SS-1, apesar de valores elevados de PG do cultivar Cristalina. A superioridade dos cultivares Cristalina e EMGOPA-301 neste grupo, também foi verificada por GOMES (1995), com semeadura em dezembro.

A variabilidade fenotípica ente plantas, para $\mathrm{PG}$, divergiu entre 78,08 (SS-1) e 3199,30 (g/planta) ${ }^{2}$ para IAC-6 em Piracicaba e 18,92 (BR-11) e $652,53(\mathrm{~g} / \text { planta })^{2}$ para IAC-8 em Maracaí. Os valores elevados em relação a outros caracteres refletem a maior suscetibilidade da PG a variações ambientais, estando este fator também associado às médias elevadas de alguns genótipos. 


\subsection{Análise das populações e testemunhas com base em plantas individuais}

\subsubsection{Florescimento e Maturidade}

As Tabelas 10 a 17 mostram os dados de caracteres relacionados ao número de dias para florescimento (NDF), altura da planta no florescimento $(\mathrm{APF})$, número de dias para a maturidade (NDM) e altura da planta na maturidade (APM), das 45 populações dos cruzamentos quádruplos e quatro testemunhas, avaliadas nos anos de 1992/93 em Piracicaba e 1993/94 em Maracaí.

São fornecidos também, os valores do número de plantas avaliadas, valores médios, percentuais em relação à média geral, mínimos, máximos, amplitudes e variâncias fenotípicas entre plantas, variâncias genotípicas, herdabilidades no sentido amplo e relações entre os coeficientes de variação genética e ambiental para cada caráter.

\subsubsection{Número de Dias para o Florescimento (NDF)}

Em média o número de dias para o florescimento (NDF) das 45 populações, obtidas por cruzamentos quádruplos entre os 20 parentais semitardios e tardios (Tabelas 10 e 11), não se alterou da geração $F_{2[4]}$ em Piracicaba, para a geração $\mathrm{F}_{3: 2[4]}$ em Maracaí, com $\mathrm{NDF}=66$ dias. Os dados referentes às testemunhas, evidenciaram uma diferença de apenas um dia entre ambientes (64 vs. 65 dias). 
As populações com florescimento mais precoce foram as de número 45 (57 e 59 dias; $F_{2[4]}$ e $\left.F_{3: 2[4]}\right)$ e 30 (58 e 59 dias; $F_{2[4]}$ e $F_{3: 2[4]}$ ), com NDF semelhantes à testemunha SS-1. O cruzamento 45 (Santa Rosa x SS-1 X IAC 80-3006 x IAC-2) possui três parentais que demonstraram certa precocidade, pois incluiu além de dois parentais semi-tardios, o cultivar IAC2 que, apesar de classificado inicialmente como tardio, demonstrou certa precocidade no experimento dos parentais (Apêndice 2; Tabela 4).

A população com maior NDF foi a de número 9 (Cristalina $x$ SS-1 X BR-11 x White Biloxi), com 86 dias na geração $F_{2[4]}$ e 77 dias em $F_{3: 2[4]}$, sendo 30 e $16 \%$ mais tardio que a média geral de todos as populações nas duas gerações. Este cruzamento envolveu três parentais (Cristalina, BR-11 e White Biloxi) relativamente tardios em NDF, sendo que BR-11 foi o parental mais tardio (80 dias) para esta característica.

Com base nos valores de amplitude do $\mathrm{NDF}$ em $\mathrm{F}_{2[4]}$, todas as populações apresentaram segregantes transgressivos, para precocidade no florescimento, em relação aos parentais e/ou testemunhas. Segregantes transgressivos com florescimento mais tardio, não foram observados somente nas populações $15,18,19,20,22,30,33,34$ e 43.

Em $\mathrm{F}_{3: 2[4]}$, apenas a população 35 (IAC-6 x SS-1 X White Biloxi x IAC80-3006) não apresentou segregantes transgressivos para precocidade no florescimento em relação aos parentais e/ou testemunhas. Segregantes transgressivos com florescimento mais tardio, também não foram observados para as populações 3, 22, 30, 33 e 43. Deve-se ressaltar que muitos cruzamentos apresentaram segregantes transgressivos para valores mínimos e máximos simultaneamente, sugerindo a existência de grande variabilidade dentro das populações. 
A herdabilidade no sentido amplo para NDF apresentou valores médios de 0,88 e 0,90 para as populações nas gerações $F_{2[4]}$ e $F_{3: 2[4]}$, com valores médios de b em 2,77 e 2,96, indicando, como demonstra a literatura, uma grande facilidade para seleção do caráter nas duas gerações avaliadas.

No entanto, alguns valores de herdabilidade, situaram-se bem abaixo do esperado, como nas populações $19(0,33$ e 0,25), $34(0,51$ e 0,47$)$ e $45(0,36$ e $0,66)$ para as gerações $F_{2[4]}$ e $F_{3: 2[4]}$, respectivamente. Esta situação refletiu uma variabilidade fenotípica e genética reduzida, destas populações em relação ao NDF. Os valores de $b$ também demonstraram uma relativa dificuldade de sucesso na seleção nestas populações, devido à presença de valores menores que 1 (um) em uma ou outra geração, pois VENCOVSKY (1987) indicou que valores maiores ou iguais a unidade indicam uma situação favorável à seleção.

As populações com maiores herdabilidades em $\mathrm{F}_{2[4]}(0,95)$, foram as de número: 5, 7, 9, 12, 17 e 36; repetindo-se esta situação em $\mathrm{F}_{3: 2[4]}$, na qual todas as populações situaram-se acima de 0,95 , com exceção das populações 7 $(0,74), 9(0,93)$ e $12(0,94)$; na geração $\mathrm{F}_{3: 2[4]}$ destacou-se também a população número $37(0,98)$. Nas duas gerações para estas populações, excluindo-se as de número 7 e 9 em $F_{3: 2[4]}$, todas as populações obtiveram coeficientes de $b$ maiores do que quatro. Comparações entre estes coeficientes, auxiliam a discriminação de populações com médias similares, indicando entre aqueles que apresentam médias elevadas, maior facilidade de seleção.

\subsubsection{Altura da Planta no Florescimento (APF)}

A altura da planta no florescimento (APF, Tabelas 12 e 13), demonstrou uma redução de $66,87 \mathrm{~cm}$ (geração $F_{2[4]}$ ) para $60,42 \mathrm{~cm}$ (geração $F_{3: 2[4]}$ ); esta 
redução também foi observada nas testemunhas, mas com menor intensidade, apresentando-se em média 4,64 cm menores em Maracaí no ano 93/94. As Populações de menor porte foram a $42(53,35 \mathrm{~cm})$ em $F_{2[4]}$ e a $45(45,42 \mathrm{~cm})$ em $\mathrm{F}_{3: 2[4]}$, contrastando com o porte elevado da população 9 (Cristalina x SS-1 X BR-11 x White Biloxi), que obteve médias de 98,52 e 92,86 cm, com valores, aproximadamente, $50 \%$ maiores que a média. Salienta-se o fato de que a obtenção de populações com menor ou maior APF não significou participação efetiva de maior número de parentais mais baixos ou mais altos (Tabela 5), com exceção da população 45 (Santa Rosa x SS-1 X IAC80-3006 x IAC-2), com todos os parentais de porte reduzido.

Segregantes transgressivos em relação ao parental de menor APF, somente não foram observados para a população 19 em $F_{2[4]}$ e para a população de número 9 em $\mathrm{F}_{3: 2[4]}$. Transgressivos superiores não foram observados para as

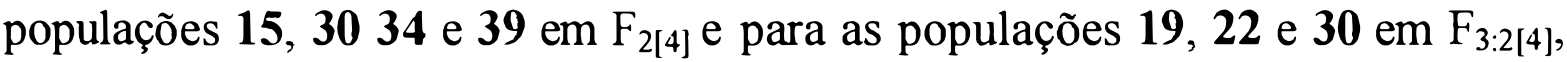
sugerindo uma possivel maior dificuldade para a seleção, principalmente dentro da população 19 (IAC-4 x IAC-6 X GO79-1039 x IAC80-3006).

A herdabilidade média da APF, no sentido amplo, foi de 0,69 para $\mathrm{F}_{2[4]} \mathrm{e}$ de 0,72 em $\mathrm{F}_{3: 2[4]}$, com valores abaixo dos descritos por BRIM (1973), por BURTON (1987) para a maioria dos trabalhos e por PACOVA (1992). As estimativas de b foram da ordem de 1,49 e 1,58, para cada geração. Valores menores em $\mathrm{F}_{2[4]}$ podem ser atribuidos a uma maior variabilidade ambiental nesta geração. Valores de b acima da unidade demonstram facilidade de seleção para o caráter, embora menor que para NDF.

As menores herdabilidades foram observadas nas populações $19(0,10)$, $30(0,19), 34(0,02)$ e $\mathbf{4 5}(-0,15)$ em $F_{2[4]}$ e nas populações $7(0,22), 19(0,20)$, $30(0,39), \mathbf{3 4}(0,33), \mathbf{4 3}(0,38)$ em $\mathrm{F}_{3: 2[4]}$; com valores de b menores que a unidade. As maiores foram obtidas para as populações 1, 5, 9, 12, 16, 17, $36 \mathrm{e}$ 
37 em $\mathrm{F}_{2[4]}$. Na geração seguinte, destacaram-se as populações $\mathbf{5}, \mathbf{8}, \mathbf{9}, \mathbf{1 2}, \mathbf{1 7}$, 32, 33, 36, 37 e 39, também com valores maiores ou próximos a 0,80 e estimativas de $\mathrm{b}$ maiores do que dois.

A repetibilidade dos resultados obtidos em algumas populações $(\mathbf{5}, \mathbf{9}, \mathbf{1 7}$, 36 e 37), com maiores herdabilidades nas duas gerações, indicam que de maneira geral, para os caracteres NDF e APF, não houve redução significativa na variabilidade genética destas populações, a despeito do tamanho efetivo populacional $(\mathrm{N}$ médio $=39$ plantas $)$ relativamente pequeno. Estes resultados corroboram com os trabalhos de PEREIRA (1980); FOUILLOUX \& BANNEROT (1988) e WEBER et al. (1990) sobre tamanho efetivo populacional, demonstrando a vantagens em se trabalhar com grande número de populações, utilizando-se menor número de plantas por cruzamento.

As populações 19, 34 e 45, apresentaram variabilidade relativamente pequena para os caracteres NDF e APF tanto em $F_{2[4]}$ quanto em $F_{3: 2[4]}$. $O$ grande número de populações apresentando segregantes transgressivos para NDF e APF nas duas gerações revelam a eficiência dos cruzamentos múltiplos em produzir novas combinações gênicas, originando farto material para a prática de seleção. Estes resultados estão de acordo com a sugestão de HANSON (1959), pela qual a inclusão de quatro ou mais parentais na população, poderia aumentar o potencial genético da população.

\subsubsection{Número de Dias para a Maturidade (NDM)}

As Tabelas 14 e 15 mostram os dados obtidos para o caráter número de dias para a maturidade (NDM), na geração $F_{2[4]}$ em Piracicaba no ano 92/93 e $F_{3: 2[4]}$ em Maracaí no ano 93/94. Em média, o NDM sofreu uma redução de 10 
dias da geração $F_{2[4]}\left(143\right.$ dias) para a geração $F_{3: 2[4]}(133$ dias), revelando a importância da influência ambiental sobre o NDM nas populações e nas testemunhas (redução de 11 dias).

A população 30 (IAC-5 x SS-1 X Tropical x IAC80-3006) foi a mais precoce com 129 e 119 dias (ciclo semelhante ao da testemunha SS-1) em $\mathrm{F}_{2[4]}$ e $\mathrm{F}_{3: 2[4]}$, contra 172 dias em $\mathrm{F}_{2[4]}$ da população 9 (Cristalina x SS-1 X BR-11 x White Biloxi) e contra 156 dias da 5 (Cristalina x IAC-6 X BR-11 x IAC803006) e da 9 em $\mathrm{F}_{3: 2[4]}$, consideradas as mais tardias. Provavelmente, a precocidade resultante da população 30 seja devida à combinação gênica de três parentais relativamente precoces em relação aos demais (IAC-5, SS-1, e IAC80-3006; Tabela 6). Na geração $F_{2[4]}$, somente não foram encontrados segregantes transgressivos superiores ao parental mais tardio, para as populações 19, 29, 30 e 34; por outro lado, todas as populações apresentaram transgressivos inferiores. $\mathrm{Na}$ geração $\mathrm{F}_{3: 2[4]}$, segregantes transgressivos inferiores ao parental mais precoce, não foram encontrados para as populações 9, 17 e 24. Transgressivos superiores ao parental mais tardio, não estiveram presentes nas populações 22, 23, 24, 29, 30 e 45.

$\mathrm{O}$ elevado número de progênies transgressivas para o caráter NDM revela a possibilidade de se selecionar linhagens com ciclo semi-precoce (116 a 125 dias) em várias populações.

A herdabilidade no sentido amplo para NDM foi de maneira geral

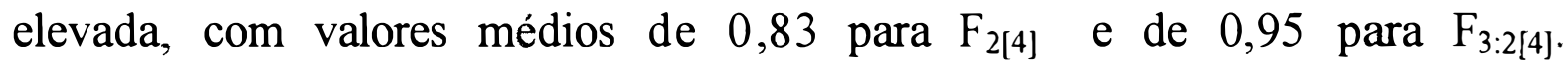
Novamente, valores mais elevados na geração $F_{3: 2[4]}$ demonstraram o menor efeito ambiental sofrido pelas populações em Maracaí. Estes valores encontram-se dentro da amplitude descrita por BRIM (1973), BURTON (1987), PACOVA (1992) e GOMES (1995), revelando ser o NDM um caráter facilmente selecionável, mesmo em gerações iniciais de endogamia. Valores de 
b maiores que a unidade $\left(2,21\right.$ e 4,32 para as gerações $F_{2[4]}$ e $\left.F_{3 \cdot 2[4]}\right)$ corroboram com esta afirmativa.

As menores herdabilidades em $\mathrm{F}_{2[4]}$, foram obtidas para as populações $19(-0,03), \mathbf{3 4}(0,26)$ e $\mathbf{4 5}(0,32)$, com estimativas de b inferiores à unidade. Já as maiores herdabilidades para NDM foram observadas para as populações 1 , $5,8,9,17,32,36$ e 37, todas com valores acima de 0,90 e com b acima de 2,5. $\mathrm{Na}$ geração $\mathrm{F}_{3 \cdot 2[4]}$, houve concordância com as populações de $\mathrm{F}_{2[4]}$ em relação às maiores herdabilidades, acrescentando-se as populações 12 e 44 (todas com estimativas de $h^{2}$ maiores que 0,96). As menores herdabilidades foram estimadas nas populações $29(0,68), 30(0,62)$ e $45(0,69)$, também com parâmetros de b menores que 1,50, bem abaixo das demais populações.

Estes resultados indicam a manutenção da variabilidade genética elevada para o caráter NDM nas populações com maior herdabilidade, através das gerações avaliadas, demonstrando que nestas populações há considerável variabilidade potencialmente útil para seleção de plantas com diferentes ciclos.

\subsubsection{Altura da Planta na Maturidade (APM)}

A altura da planta na maturidade (APM, Tabelas 16 e 17), foi bastante afetada pelas condições ambientais em Maracaí no ano 1993/94 (ver item 4.1.2 e Figura 7), em relação ao ano anterior em Piracicaba. As populações apresentaram uma redução média de $13,08 \mathrm{~cm}$, e as testemunhas de $13,99 \mathrm{~cm}$ na APM.

As populações com menor APM foram as de número 38 (IAC-8 x Santa Rosa X Paranagoiana x IAC80-3006) em $\mathrm{F}_{2[4]}(75,20 \mathrm{~cm})$ e 42 (IAC-9 x SS-1 $\mathrm{X}$ IAC-2 x Numbaíra) em $\mathrm{F}_{3: 2[4]}(55,48 \mathrm{~cm})$. Estas populações não 
apresentaram sérias restrições ao cultivo devido ao porte, embora com valores de APM inferiores ao da testemunha de menor altura (SS-1). Todavia, os valores mínimos nas duas gerações podem indicar, à principio, a existência de plantas inadequadas para a colheita mecanizada por apresentar APM abaixo de $60 \mathrm{~cm}$; mas, deve-se considerar que o cultivo em cova de planta individual reduz significativamente a APM, comparativamente com o cultivo comercial em fileiras, devido às diferenças no grau de competição entre plantas vizinhas. A população de APM mais elevada foi a 9 (Cristalina x SS-1 X BR-11 x White Biloxi; 124,71 e $121,83 \mathrm{~cm}$ ) para as duas gerações, notabilizando-a pela pequena influência ambiental na APM. Dados sobre acamamento devem ser tomados nas progênies, em gerações posteriores, com o intuito de avaliar possiveis restrições quanto a este caráter.

Segregantes transgressivos para APM com valores inferiores aos parentais, foram observados em todas as populações nas duas gerações. Transgressivos com valores superiores ao maior parental somente não foram observados nas cruzamentos 19 e 22 em $F_{3: 2[4]}$. Este fato indica que novas combinações gênicas nas progênies favorecem a seleção de plantas com porte inferior ou superior aos seus parentais, se a APM estiver dentro da concepção do genótipo idealizado pelo melhorista.

A herdabilidade média da APM, foi de 0,81 e 0,84 e as estimativas de $b$ foram 2,09 e 2,31, respectivamente para as gerações $F_{2[4]}$ e $F_{3: 2[4]}$. Pode-se considerar que, em geral, não houve redução da variabilidade genética das populações, uma vez que as variâncias fenotípicas e ambientais não apresentaram valores muito distantes entre gerações. Os valores de " $b$ " bem maiores que a unidade refletem facilidade de seleção para APM. Os valores aqui obtidos para APM encontram-se inseridos dentro dos limites relatados por PACOVA (1992) e são superiores aos obtidos por GOMES (1995). 
As menores herdabilidades foram observadas nas populações $6(0,54)$, $19(0,43)$ e $20(0,51)$, para a geração $F_{2[4]}$ e para as populações $7(0,56), 19$ $(0,25), \mathbf{2 3}(0,54)$ e $\mathbf{4 0}(0,59)$ em $F_{3: 2[4]}$, com valores de "b" próximos ou inferiores à unidade, revelando para estes cruzamentos uma maior dificuldade de seleção para APM.

As maiores herdabilidades foram estimadas para as populações $9,17,32$

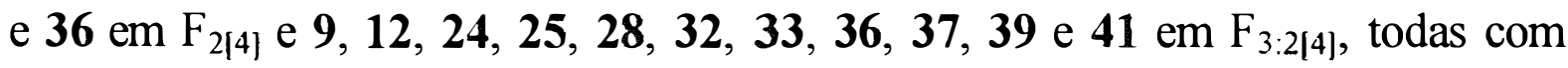
valores próximos ou maiores que 0,90 e com valores de "b" iguais ou superiores a 2,50. Estes valores indicam que estas populações apresentam grande versatilidade para a seleção de progênies para APM, sendo que esta situação se repetiu, como pode ser notado para algumas populações nas duas gerações.

Considerando os caracteres NDF, NDM, APF e APM, pode-se considerar que as populações 19, 34 e 45, possuem pequena variabilidade genética para estas características. A possibilidade dos cruzamentos não terem sido efetivos nestas populações ficou completamente descartada pela presença de plantas segregando para os genes marcadores de coloração de flor, vagem e pubescência. Apesar das plantas da população 45 apresentarem apenas flores brancas (presente nos quatro parentais), houve enorme segregação para cor das vagens e cor da pubescência (distintas nos parentais).

As populações 5, 9, 17, 32, 36 e 37, de maneira geral, apresentaram elevada variabilidade genética e amplitude de variação para os caracteres relacionados ao florescimento e maturidade. Este fato foi verificado, de maneira geral, para as duas gerações avaliadas; demonstrando maior facilidade de seleção para altura de planta e ciclo nestas populações. Em média, não houve redução da variabilidade genotípica da geração $F_{2[4]}$ para $F_{3: 2[4]}$, não 
evidenciando para a grande maioria das populações, problemas relacionados à deriva genética para estes caracteres.

\subsubsection{Valor Agronômico (VA) e Produtividade de Grãos (PG)}

As Tabelas 18 a 21 demonstram os dados de caracteres relacionados ao valor agronômico e produtividade de grãos dos quarenta e cinco cruzamentos quádruplos e quatro testemunhas avaliadas nos anos de 1992/93 em Piracicaba e 1993/94 em Maracaí.

São fornecidos também, os valores do número de plantas avaliadas, valores médios, percentuais em relação à média geral, mínimos, máximos, amplitudes e variâncias fenotípicas entre plantas, variâncias genotípicas, herdabilidades no sentido amplo e relações entre os coeficientes de variação genética e ambiental para cada caráter.

\subsubsection{Valor Agronômico (VA)}

$\mathrm{O}$ valor agronômico $(\mathrm{VA})$ médio das populações $F_{2[4]}$ e $F_{3: 2[4]}$ (Tabela 18 e 19), foi de 3,89 e 3,79, valores um pouco inferiores aos das médias das testemunhas com 4,18 e 4,20, respectivamente para Piracicaba e Maracaí, evidenciando um pequeno efeito macro-ambiental sobre estas estimativas. Por serem estimativas pessoais, subjetivas e baseadas em vários itens, sempre ajustadas pelas testemunhas, estão menos sujeitas a diferenças entre ambientes distintos, exceto para ambientes muito contrastantes. 
As menores notas de VA foram atribuídas à população 42 (IAC-9 $\mathrm{x}$ SS-1 X IAC-2 $\times$ Nunbaira) nas duas gerações $\left(F_{2[4]}=3,20\right.$ e $\left.F_{3: 2[4]}=3,24\right)$, refletindo um desempenho regular perante este critério. As maiores médias foram conferidas à população 19 (IAC-4 x IAC-6 X GO79-1039 x IAC80-3006), também nas duas gerações $(4,53$ e 4,15), superando em 16 e 10 $\%$ a média das populações.

Os valores mínimos demonstraram a existência de plantas com reduzido $\mathrm{VA}$, sendo que nas testemunhas isto pode estar relacionado à plantas doentes (viroses), atacadas por pragas e/ou manchas de solo localizadas. A presença de valores excelentes foi observada em todas as populações.

Os valores médios superiores a 3 (regular) para as populações refletiram a utilização de parentais elite nos cruzamentos, proporcionando plantas com elevado VA e resultando em incrementos na média das populações. Estes resultados podem ser considerados superiores aos obtidos por NASS (1989), onde as progênies de cruzamentos simples entre os parentais semi-tardios, revelaram desempenho regular. A presença de um maior número de plantas não adaptadas em cultivo de inverno é esperada, devido a diferenças no fotoperíodo indutivo para florescimento, escassez hídrica e temperaturas mais baixas.

A herdabilidade média e a razão "b" para o caráter valor agronômico foi

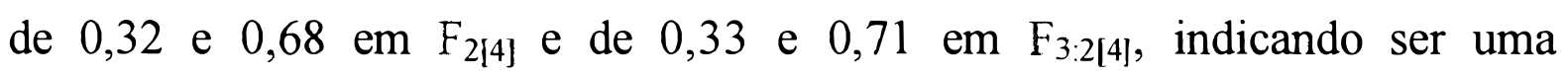
característica altamente influenciada pelo micro-ambiente experimental e de difícil seleção. Outro aspecto importante é dado pela multiplicidade e subjetividade dos componentes, avaliados visualmente e transformados em uma escala de notas, onde a margem de erro dentro e entre repetições é conseqüentemente maior. Este aspecto pode ser observado nas Tabelas 22, 23 e 24 , onde a variação para VA dentro e entre parcelas é geralmente elevado, com o erro dentro maior que entre, em todas as análises. 
A segregação dentro das populações para doenças como Septoriose (Septoria glycines), Crestamento foliar (Cercospora kikuchii), Mancha "olhode-rã" (Cercospora sojina) e plantas com sintomas de Mosaico, contribuiu para uma maior variabilidade na escala de notas, principalmente em Maracaí. Notou-se ainda, que não houve concordância para as populações nas gerações segregantes para os valores mínimos e máximos de herdabilidade e da razão "b". A variabilidade fenotípica das populações neste trabalho, foram semelhantes às obtidas por NASS (1989).

Em parte, estes resultados não estão de acordo com os relatados e obtidos por PACOVA (1992), que descreve valores de herdabilidade média entre 34 e 80 \%. Esta contradição em relação ao maior valor, deveu-se ao fato de que aqui foram utilizados somente parentais elites, que por gerarem progênies com boa adaptação e VA elevado, proporcionaram maior dificuldade na discriminação e julgamento.

\subsubsection{Produtividade de Grãos (PG)}

A produtividade média de grãos $(\mathrm{PG})$ das gerações $F_{2[4]}$ e $F_{3: 2[4]}$ estão representadas nas Tabelas 20 e 21 , onde se verificou que na localidade de Maracaí - SP no ano de 1993/94 a produtividade de grãos das populações e testemunhas $(58,76$ e $73,01 \mathrm{~g} /$ planta $)$, foi praticamente metade da obtida em Piracicaba em 92/93 (111,14 e 131,77 g/planta) para populações e testemunhas, respectivamente. Aspectos sobre estas diferenças ambientais, encontram-se discutidos nos itens 4.1 .2 e 4.1.3.

A população $F_{2[4]}$ (Tabela 20) menos produtiva foi a 9 (Cristalina $x$ SS-1 X BR-11 x White Biloxi) com $85,37 \mathrm{~g} /$ planta (77 \% da produtividade 
média das populações), sendo que a testemunha menos produtiva SS-1, alcançou uma média de 119,08 g/planta, com produtividade $17 \%$ menor que Cristalina (141,12 g/planta). Em $\quad F_{3: 2[4]}$ (Tabela 21), a população 17 (EMGOPA-301 x SS-1 X BR79-63 x White Biloxi) obteve menor produtividade, somando 40,56 g/planta (69 \% da média das populações) e a testemunha menos produtiva SS-1, obteve $65,83 \mathrm{~g} / \mathrm{planta}$ (90\% da média das testemunhas), produtividade $19 \%$ menor que Cristalina, com maior PG $(79,25$ g/planta).

Os valores mínimos de $P G$ das populações em relação às testemunhas acusaram em praticamente todas as populações, plantas com pequena produtividade de grãos. As amplitudes verificadas demonstraram grandes diferenças existentes para o caráter dentro das populações.

As maiores produtividades foram alcançadas pela população 21 (IAC-4 x IAC-9 X GO79-1039 x Paranagoiana) com 147,31 e 73,89 g/planta nas gerações $F_{2[4]}$ e $F_{3: 2[4]}$ e pela população 23 (IAC-4 x Santa Rosa X G079-1039 x Tropical) com 140,38 e 73,77 g/planta, respectivamente para as gerações $\mathrm{F}_{2[4]}$ e $\mathrm{F}_{3: 2[4]}$. Estes valores foram 26 a $30 \%$ superiores à média das populações, com PG comparadas à testemunha mais produtiva em $\mathrm{F}_{2[4]}$ (Cristalina com 141,12 g/planta), porém inferiores à EMGOPA-301 e Cristalina $\left(80,96\right.$ e 79,25 g/planta) em $\mathrm{F}_{3: 2[4] \text {. }}$

A herdabilidade média das populações para $P G$ foi de 0,64 e de 0,54 para as gerações $F_{2[4]}$ e $F_{3: 2[4]}$, com valores de $b$ em 1,34 e 1,07, respectivamente. Os valores de $\mathrm{b}$ maiores em $\mathrm{F}_{2[4]}$ demonstram uma facilidade de seleção um pouco maior para este caráter nesta geração. A variabilidade média da geração $\mathrm{F}_{2[4]}$ apresentou, em média, valores superiores aos demonstrados por WERNER \& WILCOX (1990) na população $\mathrm{C}_{0}$ e no primeiro ciclo de seleção recorrente para produtividade em soja. 
Conforme pode ser observado nas Tabelas 20 e 21 , os valores da variância genética nas populações para o caráter PG foram bastante elevados, com desvios em torno de $31 \%$ da média das populações nas duas gerações, sendo este o caráter com maior coeficiente de variação genética avaliado. No entanto deve-se enfatizar que a variabilidade ambiental também foi alta, evidenciando, reduções proporcionalmente maiores na herdabilidade e razões de " $b$ " que os caracteres ligados ao florescimento e a maturidade.

Os valores de herdabilidade, aqui encontrados, situam-se dentro dos limites descritos por PACOVA (1992), com a estimativa para $F_{2[4]}$, um pouco maior que o valor máximo descrito por BRIM (1973) e por BURTON (1987). Todavia, em trabalhos de seleção recorrente, nos quais a utilização de cruzamentos múltiplos é comumente empregada, herdabilidades para PG semelhantes ou um pouco superiores foram observadas por SCHAPAUGH \& WILCOX (1980), WILCOX \& MAY (1986), BURTON et al. (1990) e por ROSE et al. (1992), que explicaram o fato como sendo devido à enorme variação genética da população básica.

As menores herdabilidades para PG e razões de $b$ foram obtidas para as populações 45 em $F_{2[4]}(0,18$ e 0,46$)$ e para as populações $25,31,38$ e 40 em $F_{3: 2[4]}$ (herdabilidades e valores de $b$ considerados nulos). Nota-se que em $F_{2[4]}$, com exceção da população 40 , todas as outras $(25,31$ e 38) também obtiveram valores de herdabilidade relativamente baixos (por volta de 0,50 ) em relação à média $(0,62)$. A ausência de variabilidade genética para $P G$ em $F_{3: 2[4]}$ para estas populações, pode estar relacionada com a deriva genética, sendo este fato destacado por GALLAIS (1977) e FOUILLOUX \& BANNEROT (1988), que sugeriram a manutenção da variabilidade em programas de seleção recorrente ou por manter uma população básica submetida à baixa intensidade de seleção, ou por providenciar um número maior de fileiras de progênies. A presença de 
ligações em associação, seria outro fator que pode estar relacionado ao decréscimo da variância genética após intercruzamentos (PIPER \& FEHR, 1987).

No entanto, deve ser enfatizado que as herdabilidades no sentido amplo obtidas neste trabalho (com exceção de $\mathrm{VA}$ para $\mathrm{F}_{2[4]}$ ) foram superiores às obtidas por NASS (1989) para os caracteres NDF, APF, NDM, APM, VA e $P G$ em populações $F_{2}$ formadas por dialelo entre os mesmos parentais semitardios aqui utilizados. Isto sugere que a inclusão de parentais tardios em um esquema de cruzamentos quádruplos aumentou a variabilidade genética das populações resultantes, sendo que as médias obtidas no presente trabalho (com exceção de $\mathrm{PG}$ em $\mathrm{F}_{3: 2[4]}$ ) foram superiores às obtidas por aquele autor.

\subsection{Análises com base na média de repetições}

\subsubsection{Análises de variância por a mbiente}

As sínteses das análises de variância, para blocos casualizados, de parentais, testemunhas, populações e populações vs. testemunhas, nas gerações $F_{2[4]}$ e $F_{3: 2[4]}$, são demonstradas nas Tabelas 22 e 23. Nas mesmas, também constam, estimativas de quadrados médios, médias e coeficientes de variação, por ambiente (ano e local).

Em geral os coeficientes de variação obtidos nos ensaios foram considerados aceitáveis e até relativamente baixos, com valores menores que 6 \% para caracteres de alta herdabilidade como número de dias para 0 florescimento (NDF) ou maturidade (NDM), e menores que $21 \%$ para caracteres com menores herdabilidades, como altura da planta no florescimento 
(APF) e maturidade (APM), valor agronômico (VA) e produtividade de grãos (PG). Considerando-se parcelas formadas por 12 plantas individuais no caso de populações e testemunhas, e de 6 plantas no caso de parentais, estes valores tornam-se mais significativos se forem consideradas possiveis diferenças genotípicas ocorridas entre progênies, dentro de cada cruzamento, nas diferentes repetições. A funcionalidade e eficiência de testes de progênies baseados em parcelas em covas é descrita por FEHR (1987a), onde estas parcelas podem acomodar grande número de progênies com utilização de poucas sementes. KENWORTHY \& BRIM (1979) demonstraram bons resultados com a utilização de parcelas de nove covas, na seleção de parentais para intercruzamentos a cada novo ciclo de seleção para produtividade de grãos.

Para os dois ambientes avaliados (Tabelas 22 e 23), houveram diferenças significativas pelo teste $F(p \leq 0,05)$ entre parentais para todos os caracteres avaliados, com exceção de VA em Piracicaba. As testemunhas não diferiram entre si apenas para VA e PG (exceção de VA em $\mathrm{F}_{2[4]}$ ). As médias elevadas para os dois caracteres indicaram que estes materiais possuem boas características agronômicas e boa adaptação nos ambientes testados, sendo acertada a escolha das mesmas como testemunhas. Diferenças entre altura de planta e ciclo, também são desejáveis para comparações com as populações quanto à divergências neste aspecto.

As análises para Genótipos (testemunhas + populações) e para as populações nas duas gerações, demonstraram que os cruzamentos proporcionaram diferenças altamente significativas $(\mathrm{p} \leq 0,01)$ para todos os caracteres. Este resultado demonstrou que a seleção entre populações deve ser efetiva, uma vez que existiram diferenças entre altura, ciclo, valor agronômico e produtividade entre as mesmas. 
O fator Testemunhas vs. Populações, não apresentou diferenças significativas para os caracteres NDF, APF, NDM e APM (exceção de APM para $\left.F_{3: 2[4]}\right)$ nas duas gerações. Diferenças altamente significativas foram observadas para os caracteres VA e PG, indicando que em média as testemunhas tiveram valores agronômicos e produtividades significativamente superiores a média das populações (tabelas 22 e 23).

\subsubsection{Análises de variância conjuntas em dois ambientes para parentais e testemunhas}

As análises conjuntas (Tabela 24) de parentais e testemunhas demonstraram diferenças significativas entre genótipos para todos os caracteres, com exceção do valor agronômico (VA).

Diferenças ambientais significativas foram encontradas para todos os caracteres, com exceção de NDF, APF e VA, indicando que estes três caracteres foram pouco afetados pelo ambiente. Com a análise da Figura 7 (considerando-se a irrigação das mudas em dezembro em Piracicaba), verificase que até a época do florescimento da maior parte dos genótipos não ocorreram limitações hídricas em nenhuma localidade/ano. A partir de fevereiro, ocasionais "déficts" hídricos, somados a uma maior compactação de camadas inferiores do solo em Maracaí, favoreceram diferenças entre os ambientes, acentuando ocasionais diferenças obtidas nos demais caracteres obtidos após o florescimento.

A interação genótipo $x$ ambiente foi significativa para NDF, NDM, VA e PG, nos parentais indicando que os mesmos possuíram respostas diferenciadas para estes caracteres nos dois ambientes avaliados, demonstrando 
a necessidade de seleção das populações provenientes destes cruzamentos em mais de um ambiente.

Estes resultados estão de acordo com os obtidos por SOLDINI (1993) para 68 genótipos precoces e 22 tardios no Estado de São Paulo e por ALLIPRANDINI et al. (1994) para genótipos precoces, semi-precoces e médios no Estado do Paraná. Forte interação entre genótipos (semi-tardios e tardios) e épocas de cultivo foi detectada por FARIAS NETO (1987).

Para as testemunhas, o desempenho entre genótipos para todos os caracteres (exceto NDM), foi constante de um ambiente para outro, evidenciando a ausência de interações genótipos por ambientes, o que é desejável para comparações com as populações. A análise conjunta demonstrou diferenças fenotípicas significativas para todos os caracteres exceto VA, indicando que as testemunhas se eqüivalem em valor agronômico na média dos dois ambientes. Estes resultados demonstraram que a escolha deste conjunto de testemunhas foi representativo, para comparações com as populações.

\subsection{Agrupamento de médias pelo critério de Scott-Knott}

Nas Tabelas 25, 26 e 27, estão apresentadas as médias de seis caracteres e classificações para os ensaios de parentais e de populações $F_{2[4]}$ e $F_{3: 2[4]}$ em Piracicaba 92/93 e Maracaí 93/94, segundo o critério de SCOTT-KNOTT (1974). Este método demonstra a utilidade e praticabilidade na subdivisão de grupos de genótipos similares. PACOVA (1992) cita este método como técnica auxiliar aos melhoristas de plantas no planejamento de futuros cruzamentos, 
fornecendo referências preliminares sobre a divergência genética dos genótipos envolvidos e diferenciando grupos próximos ou distantes para a característica.

\subsubsection{Agrupamento de médias de 20 parentais}

Para os 20 parentais avaliados no ensaio de Piracicaba em 1992/93 (Tabela 25), houve formação de grupos distintos para apenas três dos seis caracteres avaliados. Em NDF houve formação de 6 grupos (a até f) e para APF e NDM, apenas dois grupos (a e b). Para APM, VA, e PG, apesar do teste F demonstrar diferenças significativas entre genótipos, não foram diferenciados grupos de médias distintos para os caracteres APM e VA no teste de ScottKnott. Segundo PIMENTEL GOMES (1982) tais discordâncias se devem a aceitação de hipóteses diferentes nas deduções teóricas, e são, aliás, de pouca importância prática.

Diferenciação em grupos de parentais para todos os caracteres, exceto para VA, foram detectados em Maracaí em 1993/94 (Tabela 25). Este resultado demonstra que este ambiente foi mais favorável para a discriminação de genótipos, com exceção da avaliação visual.

Foram detectados 8 grupos distintos para NDF (a até h), 3 grupos para APF e NDM (a até c) e por fim, 2 grupos para APM e PG (a e b). ALLIPRANDINI et al. (1994) destacaram a importância de ambientes com

este tipo de resposta, para a realização de testes de avaliação genotípica. A seguir são fornecidos as informações referentes aos grupos e classificações dos genótipos, sempre em ordem decrescente para o caráter.

Considerando-se a característica NDF, o grupo de parentais com florescimento mais precoce em Piracicaba, foi composto pelos cultivares: 
IAC-2, IAC-4, IAC-5, Santa Rosa e SS-1; com início de florescimento variando entre 56 e 60 dias. Timbira foi o cultivar com florescimento mais tardio (83 dias), se destacando dos demais genótipos. Em Maracaí, SS-1 apresentou-se como a mais precoce, florescendo com 56 dias. Timbira e BR-11 foram os mais tardios, com 79 e 80 dias de NDF, respectivamente. Estes resultados concordam com aqueles descritos por ALMEIDA et al. (1991a; Apêndice 2), para a região de Londrina (Lat. $23^{\circ}, 22^{\prime} \mathrm{S}$; altitude de $585 \mathrm{~m}$.) no Estado do Paraná.

O grupo com plantas de maior APF em Piracicaba foi: Tropical, GO79-1039, IAC-6, EMGOPA-301, BR79-63, BR-11 e IAC-9, com porte variando entre 90 e 72,95 cm. Em Maracaí 93/94, este grupo foi composto pêlos genótipos: GO79-1039, BR-11, Timbira, Tropical, e BR79-63, com extremos de 82,32 A 75,33 cm.

A divisão de grupos de médias para NDM neste trabalho, forneceu informações úteis a respeito do ciclo dos genótipos avaliados. Em Piracicaba houve a formação de dois grupos distintos, concluindo-se que nas condições deste experimento os genótipos com maior ciclo foram: BR-11, Timbira, GO79-1039, EMGOPA-301, BR79-63, Cristalina, Tropical, IAC-6, Paranagoiana e IAC-9, com ciclo de 162 a 147 dias. Em Maracaí, no ano seguinte, houve a divisão em três grupos, sendo que os genótipos mais tardios foram: GO79-1039, BR79-63 e Tropical (grupo a; 154 a 149 dias) e BR-11, Timbira, IAC-9, EMGOPA-301, IAC-2, IAC-6 e Cristalina (grupo b; 144 a 137 dias). Os resultados descritos por ALMEIDA et al. (1991a), para Londrina estão mais coerentes com os de Piracicaba; sendo que em Maracaí no ano 93/94, os genótipos geralmente adiantaram o ciclo em relação à Londrina e Piracicaba. 
Percebe-se que uma classificação dos genótipos em grupos de maturação pré-determinados torna-se difícil em função de diferenças ambientais existentes entre as localidades, bem como, das interações genótipos $\mathrm{x}$ ambientes verificadas para esta característica (Tabela 24), necessitando uma maior quantidade de ensaios em épocas e locais distintos para uma classificação mais confiável, além do que, este aspecto foge do escopo deste trabalho.

O caráter APM apenas apresentou distinção para grupos de genótipos em Maracaí, onde os genótipos de maior porte foram: IAC-2, GO79-1039, Tropical, White Biloxi, BR-11, BR79-63, IAC-5, Timbira e EMGOPA-301, variando de 102,75 a $81,80 \mathrm{~cm}$; com resultados nos dois locais um pouco menores que a descrição fornecida por ALMEIDA et al. (1991a) em Londrina no Paraná.

É importante ressaltar quanto a este caráter que nenhum parental apresentou restrição por apresentar altura demasiadamente baixa para colheita mecanizada (BONETTI, 1983). Outro aspecto refere-se ao grande desenvolvimento dos cultivares IAC-2 e IAC-5 após o florescimento, causado pelo hábito de crescimento indeterminado destes cultivares, conforme descrição fornecida por ALMEIDA et al. (1991a; Apêndice 4).

$\mathrm{O}$ caráter VA não apresentou grupos diferenciados em nenhum dos ambientes avaliados, refletindo o bom comportamento e valor genotípico elevado dos parentais avaliados em vários ensaios e/ou ambientes, antes de serem recomendados ou tornarem-se linhagens elites puras (BONETTI, 1983).

Para o caráter PG houve a formação de dois grupos (a e b) apenas em Maracaí 93/94, sendo que em Piracicaba 92/93 todos os parentais situaram-se no mesmo conjunto, embora por outros testes de médias (Tukey e Duncam; não demonstrados neste trabalho) verificou-se uma tendência de diferenciação de BR-11 em relação aos demais, por possuir baixa PG. 
Em Maracai os parentais situados no grupo de maior PG foram: Cristalina, SS-1, EMGOPA-301, IAC-4, IAC-9, e White Biloxi, com PG variando de 102,4 g/planta até $81,44 \mathrm{~g} /$ planta. Deve-se ressaltar que o desempenho de IAC-4 e White Biloxi em Piracicaba, foi comparativamente inferior à Maracaí, sendo o inverso para GO79-1039 e Tropical em Piracicaba, demonstrando grande interação com o ambiente para estes genótipos, conforme demonstra a significância do teste F na Tabela 24. O genótipo BR-11 mostrouse pouco produtivo nos dois locais avaliados.

Dos resultados obtidos nos dois ambientes, pode-se concluir que os parentais mais adaptados nas condições deste trabalho foram Cristalina, EMGOPA-301, IAC-9 e SS-1, demonstrando APM, VA e PG elevadas nos dois ambientes, além de aparentar boa estabilidade fenotípica nos dois ambientes. Estes parentais, com exceção de EMGOPA-301 (NASS, 1989) e SS-1 (GOMES, 1995), obtiveram médias elevadas em relação a outros parentais considerados semi-tardios em cultivo de outono/inverno (NASS, 1989) e de verão (GOMES, 1995). Resultados superiores também foram demonstrados para Cristalina na semeadura de verão em Piracicaba, onde para um grupo de 30 genótipos testados para produtividade, houve uma correlação de 0,35 (não significativa) entre os resultados de cultivos no inverno e verão (FARIAS NETO, 1987).

\subsubsection{Agrupamento de médias de 45 populações e quatro testemunhas}

Considerando as médias e classificações apresentadas nas Tabelas $26 \mathrm{e}$ 27, considerou-se que para as 45 populações $F_{2[4]}$ e 4 testemunhas, avaliadas em Piracicaba 92/93, houve a formação de cinco grupos (a - e) de médias para 
as características NDF e NDM, 4 grupos $(\mathrm{a}-\mathrm{d})$ para APF, 3 grupos $(\mathrm{a}-\mathrm{c})$ para APM e somente dois grupos $(\mathrm{a}-\mathrm{b})$ para VA e PG. A geração $F_{3: 2[4]}$ em Maracaí 93/94 constou da formação de 4 grupos (a - d) para NDF, APF, NDM e APM, com dois grupos ( $\mathrm{a}-\mathrm{b})$ para os caracteres VA e PG.

\subsubsection{Florescimento e Maturidade}

As populações $\mathrm{F}_{2[4]}$ e/ou testemunhas em Piracicaba, com menor Número de Dias para o Florescimento (NDF; grupo e) foram: 45, SS-1, 30, 42 , IAC-8, 11, 20, 29, 34, 38, 3, 18, 24, 32, 35, 41, 39 e 43, com 57 a 62 dias da semeadura. Em Maracaí houve concordância com estes resultados em 72 \% destes genótipos (grupo $d$ ), excluindo-se somente as populações $F_{3: 2[4]}$ de número 3, 18, 20, 24 e 43. A amplitude de florescimento para este grupo foi de 59 a 63 dias após a semeadura.

As populações $\mathrm{F}_{2[4]}$ com maior NDF em Piracicaba foram as de número 9 (grupo a; 90 dias), mais as de número 17, 5, 6 e 14 do grupo b, com 78 a 76 dias para o florescimento. Em Maracaí, as populações $F_{3: 2[4]}$, com maior NDF foram as populações $9,17,5,6$ e 37 (grupo a), com número de dias para o florescimento variando de 77 até 73 dias.

As populações e testemunhas com menor Número de Dias para a Maturidade (NDM), representadas pelo grupo e (127-137 dias) em Piracicaba e pelo grupo d (117-127 dias) em Maracaí, comuns nas duas gerações, foram: 42, SS-1, 39, 29, 24, 38, 35, 41, 30, 32, 45. Em Piracicaba a geração $F_{2[4]}$, incluiu ainda as populações de número 23, 20 e 34. Em Maracaí (geração $\mathrm{F}_{3: 2[4]}$ ) a testemunha IAC-8 e a população 33, também foram incluídas no grupo com maior precocidade. 
O caráter NDM foi muito elevado para as populações 9 e 5 (grupo a; 176 e 169 dias) em Piracicaba, com valores superiores ao parental mais tardio BR-11 (162 dias) e à testemunha EMGOPA-301 (151 dias). No grupo b somam-se as populações 6 e 17 (160 e 164 dias), também consideradas tardias. A situação na geração $F_{3: 2[4]}$ em Maracaí não mudou muito, apesar da redução observada no ciclo. As populações mais tardias (grupo a) foram as mesmas dos grupos a e b na geração anterior, com intervalo até a maturidade de 156 dias (população 5) a 147 dias (população 6). A testemunha mais tardia foi novamente EMGOPA-301 com 143 dias para a maturidade.

A população com maior Altura da planta no florescimento (APF) e na maturidade (APM) nas duas gerações, foi a 9 (Cristalina $\times$ SS-1 X BR-11 x White Biloxi), com 96,95 e 92,54 cm no florescimento e com 119,11 e 121,58 $\mathrm{cm}$ na maturidade, respectivamente para $\mathrm{F}_{2[4]}$ e $\mathrm{F}_{3: 2[4]}$ em cada caráter. Esta população constituiu um grupo isolado (a), superior às testemunhas e mesmo ao maior parental. No grupo b para APF, houve coincidência de $62 \%$ dos materiais nas duas gerações, envolvendo os genótipos: EMGOPA-301, 5, 6, 8, 12, 17 e 37. Somam-se a estes em Piracicaba, as populações 7, 13, 14, 16, 19 , e 36, que neste local também apresentaram porte elevado. Para APM, esta coincidência entre gerações dos genótipos situados no segundo grupo de maior porte, se elevou para $75 \%$, sendo estes: EMGOPA-301, 3, 5, 6, 8, 17, 18, 24, 25, 28, 29, 33, 34, 37 e 43. Em Piracicaba juntou-se a estes as populações 16, 19, 26 e 36 e em Maracaí a população de número 12.

Nos grupos de menor porte para as duas gerações, não houve nenhuma população com altura limitante no florescimento e maturidade. Nota-se, que houve para as características relacionadas com o ciclo e altura das plantas, grande coincidência de resultados nas duas gerações e/ou locais, sugerindo não haver grandes alterações de posto na maioria das populações mais precoces ou 
tardias, ou mesmo naquelas de menor ou maior porte de uma geração para outra, indicando certa coerência nos resultados obtidos nos dois ambientes, facilitando a seleção para estes caracteres.

\subsubsection{Valor Agronômico (VA) e Produtividade de Grãos (PG)}

A divisão do caráter Valor Agronômico (VA) em apenas dois grupos (Tabelas 26 e 27), com médias acima de 3,50, revela que apesar da existência de grupos distintos nos dois ambientes, a grande maioria das populações e testemunhas foram consideradas na média, como possuidoras de boas características agronômicas. Poucas populações obtiveram VA regular, reflexo da utilização de parentais com comprovado valor agronômico, como pode ser observado na Tabela 25.

Notas inferiores foram atribuídas por NASS (1989) em cultivo de inverno e por GOMES (1995) em cultivo de verão, com os mesmos parentais semi-tardios e progênies resultantes do dialelo entre estes parentais. Menores valores também foram atribuídos por PACOVA (1992), onde progênies foram obtidas de cruzamentos entre parentais adaptados e parentais tipo hortaliça. Deve-se ter em mente que o conceito de valor agronômico, depende da concepção de cada melhorista, dos genótipos avaliados e do efeito ambiental sobre estes genótipos.

As populações e testemunhas com maior VA, comuns tanto em Piracicaba 92/93 quanto em Maracaí 93/94, foram: 19, EMGOPA-301, 6, 37, Cristalina, 40, 16, 14, 21, 22, 36, 8, 23, 20, 4 e SS-1; correspondendo a $54 \%$ dos genótipos do grupo (a) nos dois ambientes. As populações não comuns com maior nota em Piracicaba foram as de número 2, 5, 31 e 26, sendo que em 
Maracaí se destacaram: IAC-8, 7, 15, 24, 28, 29, 30, 35 e 44. As notas do grupo (a) variaram de 4,54 (população 19) a 4,01 (SS-1) em Piracicaba e de 4,40 (EMGOPA-301) a 3,85 (população 7) em Maracaí.

O sucesso de uma linhagem, contudo, não depende apenas e tão somente da arquitetura da planta, quantidade de vagens cheias, vigor, sanidade das plantas, debulha prematura das vagens, acamamento e retenção foliar, sendo necessário, também, apresentar boa estabilidade ambiental e produtividade de grãos. Neste aspecto, a repetibilidade de resultados nos dois ambientes avaliados torna-se de grande importância na seleção de populações e/ou progênies com potencial de tornarem-se linhagens elites, seja para uso direto como cultivares ou para utilização em novos cruzamentos em programas de seleção recorrente.

Em Piracicaba no ano 1992/93 as populações $F_{2[4]}$ e testemunhas que situaram-se dentro do grupo (a) de maior PG foram: 21, Cristalina, 23, 19, EMGOPA-301, 22, 16 e IAC-8, com valores entre 147,98 a 125,36 gramas/planta. As populações $F_{3: 2[4]}$ e testemunhas do grupo de maior produtividade de grãos em Maracaí no ano de 1993/94, foram: Cristalina, EMGOPA-301, 23, 3, 6, 21, 34, 41, 29, 22, IAC-8, 19, SS-1, 9, 20, 8, e 24, com valores situados entre 82,17 a $62,61 \mathrm{~g} /$ planta. Estes resultados demonstram que apesar da segregação dentro destas populações, elas apresentaram PG semelhantes aos melhores parentais deste ensaio, cultivares de comprovado sucesso na agricultura brasileira principalmente na região centro-oeste (SPEHAR et al., 1993 e SPEHAR, 1994).

As populações 19, 20, 21, 22, 23 e 24, possuíram elevada adaptação produtiva e aparentemente, boa estabilidade ambiental; demonstrando que $o$ cruzamento do cultivar IAC-4 com IAC-6, IAC-8, IAC-9, IAC-11, Santa Rosa e SS-1 quando cruzados respectivamente nesta ordem, com o cruzamento da 
linhagem GO79-1039 com IAC80-3006, Numbaíra, Paranagoiana, Timbira, Tropical e White Biloxi (Apêndice 6), produziram populações produtivas e de elevados valores agronômicos nos dois ambientes avaliados (Tabela 26 e 27).

Estes resultados em relação ao cultivar IAC-4, não corroboram com os obtidos por NASS (1989) e por GOMES (1995), onde as progênies de cruzamentos deste cultivar, obtiveram no geral médias reduzidas, capacidade específica de combinação baixas; além do cultivar IAC-4, só perder em capacidade geral de combinação para Santa Rosa (NASS, 1989). Estas contradições, somadas às baixas correlações entre genótipos em cultivo de verão e inverno apontadas por FARIAS NETO (1987), revelam o cuidado que se deve ter na interpretação de resultados, na presença de interações do tipo genótipos $\mathrm{x}$ ambientes. No entanto, também demonstram a importância dos cruzamentos múltiplos na introdução de novas combinações gênicas, resultando algumas vezes em populações superiores, anteriormente não verificadas em um cruzamento simples.

\subsection{Correlações entre caracteres}

\subsubsection{Correlações fenotípicas, genotípicas e residuais entre caracteres}

$\mathrm{Na}$ Tabela 28 estão demonstradas estimativas de covariâncias fenotípicas, residuais e genéticas obtidas das análises de covariância entre seis caracteres, combinados dois a dois, com base em médias de parcelas com quatro repetições. Estas estimativas, juntamente com as variâncias descritas nas Tabelas 22 e 23, foram utilizadas para calcular conseqüentes correlações 
para testemunhas, populações $F_{2[4]}$ e $F_{3: 2[4]}$ nos ambientes de Piracicaba 92/93 e Maracaí 93/94, que por sua vez, estão listadas na Tabela 29.

Conforme pode ser observado na Tabela 29 as estimativas das correlações genéticas foram de um modo geral, um pouco superiores às fenotípicas, evidenciando nestes casos, correlações ambientais menos pronunciadas entre estes caracteres (VENCOVSKY \& BARRIGA, 1992b). Todavia, correlações residuais mais expressivas foram observadas entre as características NDF x APF, NDF x NDM e APF x APM nos dois ambientes e VA x PG em Maracaí, indicando que os efeitos ambientais influenciaram de maneira semelhante estas características.

Devido ao fato de que para fins de melhoramento devemos nos preocupar sobretudo com associações de natureza genética (VENCOVSKY \& BARRIGA, 1992b), daqui por diante maior ênfase será dado a este aspecto.

\subsubsection{Número de Dias para o Florescimento (NDF)}

Observa-se (Tabela 29), correlações genéticas elevadas e altamente significativas entre número de dias para florescimento (NDF) com: APF $(0,89$ e 0,$99 ; 0,76$ e 0,93$), \operatorname{NDM}(0,94$ e 0,$96 ; 1,00$ e 0,94$)$ e $\operatorname{APM}(0,92$ e 0,62; 0,85 e 0,60), respectivamente para testemunhas e populações $F_{2[4]} \mathrm{em}$ Piracicaba 92/93, seguidos pelos valores de testemunhas e populações $F_{3: 2[4]} \mathrm{em}$ Maracaí 93/94. Estes valores indicam que, de maneira geral, testemunhas e populações com florescimento mais tardio obtiveram maior altura no florescimento, na maturidade, e também tiveram maiores ciclos nos dois ambientes e gerações avaliados. Resultados semelhantes foram descritos por WEBER \& MOORTHY (1952), JOHNSON et al. (1955) e por PACOVA 
(1992), que reuniu elevadas correlações entre estes caracteres de diversos autores.

Associações positivas e significativas entre NDF e VA (1,24 e 0,64; 0,78 e 0,20 ) foram observadas somente para testemunhas nos dois ambientes e para populações $\mathrm{F}_{2[4]}$, o mesmo não ocorrendo para populações na geração $\mathrm{F}_{3: 2[4]}$ em Maracaí. Esta associação, quando ocorre de maneira significativa, somada à correlações entre NDF x APF e NDF x PG (FARIAS NETO, 1987; NASS, 1989 e PACOVA, 1992), são de grande importância para cultivos de inverno e para regiões de baixa latitude.

Associações positivas significativas entre NDF x PG, em Piracicaba e Maracaí, foram verificadas para as testemunhas (1,33 e -0,02;0,93 e -0,20), sendo que o oposto ocorreu para as populações $F_{2[4]}$ e $F_{3: 2[4]}$, indicando que as populações com florescimento mais tardio, não foram via-de-regra mais produtivas, fato este que pode ser comprovado observando-se os valores da Tabela 26 para testemunhas e populações. Ampla gama de valores, também são demonstrados na literatura para este tipo de correlação (PACOVA, 1992).

\subsubsection{Altura de Planta no Florescimento (APF)}

O caráter altura de planta no florescimento (APF), nos dois ambientes estudados apresentou correlações genéticas elevadas e altamente significativas com: $\operatorname{NDM}(0,80$ e 0,$93 ; 0,79$ e 0,90$)$ e APM $(0,98$ e 0,$60 ; 1,00$ e 0,78); respectivamente, para testemunhas e populações $F_{2[4]}$ em Piracicaba 92/93, e em seguida para testemunhas e populações $F_{3: 2[4]}$ em Maracaí 93/94 (Tabela 29). O mesmo foi observado para APF $x$ VA, somente para testemunhas e populações $F_{2[4]}$ em Piracicaba $(0,85$ e 0,64$)$. A correlação APF x PG, foi de 
importância em relação às testemunhas nos dois ambientes, o mesmo não ocorrendo para as duas gerações das populações $(0,94$ e 0,$07 ; 0,53$ e -0,15), com valores reduzidos ou negativos.

Estes dados indicam que houve uma tendência de genótipos com maior APF possuírem maiores ciclos e maior altura na maturidade. Genótipos com maior valor agronômico foram associados com maior altura no florescimento em Piracicaba, o mesmo não ocorrendo em Maracaí. Testemunhas com maior APF apresentaram tendências à maiores produtividades nos dois ambientes. $\mathrm{O}$ mesmo não pôde ser aplicado às populações.

\subsubsection{Número de dias para a maturidade (NDM)}

O caráter número de dias para a maturidade NDM, tanto em Piracicaba quanto em Maracaí, demonstrou correlações genotípicas positivas e de altas significâncias com APM $(0,70$ e 0,$62 ; 0,86$ e 0,67), com valores sempre mais elevados para as testemunhas. Os genótipos mais tardios geralmente apresentaram plantas de maior porte, independendo do ambiente e geração avaliada. O caráter NDM apresentou correlação elevada com VA $(0,91)$ somente para testemunhas em Piracicaba, sendo que em Maracaí (-0,01), a correlação foi nula para populações. Testemunhas em Maracaí $(0,36)$ e populações em Piracicaba $(0,56)$ apresentaram valores médios.

Testemunhas com maior NDM apresentaram elevada correlação com PG nos dois ambientes, porém não houve concordância para as duas gerações nas populações $(1,43$ e $-0,09 ; 1,21$ e -0,25). Embora não significativos, a presença de valores negativos para NDM x PG sugerem que a seleção de genótipos muito tardios poderia levar a um decréscimo na produtividade. Este fato pode 
ser melhor observado na Figura 7, onde a falta de chuvas torna-se acentuada a partir do segundo decêndio de abril, prejudicando as populações com granação mais tardia.

A seleção de plantas para NDM é um fator extremamente relevante, principalmente em épocas e/ou locais onde a ocorrência de chuvas é errática e o perigo de injúria por frio torna-se uma constante, como ocorre em semeaduras tardias e no cultivo de outono/inverno. Estes resultados concordam com os obtidos em seleção recorrente por SUMARNO \& FEHR (1982), que obtiveram maiores ganhos com materiais precoces que tardios, e por HANSON (1992), que destaca a ineficiência de associações positivas entre período reprodutivo e produtividade em ambientes com deficiência hídrica. Todavia, uma enorme variação de resultados para estas correlações foram descritas conjuntamente por ANAND \& TORRIE (1963), KWON \& TORRIE (1964), SCHAPAUGH JR. \& WILCOX (1980), NELSON (1986) e PACOVA (1992).

\subsubsection{Altura de Planta na Maturidade (APM)}

O caráter altura de plantas na maturidade (APM) não apresentou correlações genéticas significativas com VA, exceto nas testemunhas em Piracicaba $(0,88)$. Associações positivas e altamente significativas entre APM e PG, foram observadas para as testemunhas nos dois ambientes, com resultados não significativos para populações $(0,86$ e -0,18; 0,66 e 0,08). Ao que parece, populações mais altas não foram associadas com maior VA e PG. Uma vez que a grande maioria das plantas não apresentaram limitações quanto à altura na colheita, este aspecto deixou de ser relevante para o caráter VA. 
Para genótipos tardios, esta associação positiva entre APM x VA poderia até ser prejudicial, se erroneamente utilizada. Plantas mais altas poderiam levar a um maior índice de acamamento em semeaduras mais densas, ou na presença de ventos fortes, comuns em cultivo de outono/inverno.

\subsubsection{Produtividade de Grãos (PG)}

Correlações positivas e significativas de testemunhas e populações entre VA x PG foram observadas em Piracicaba 92/93 (1,45 e 0,64) e em Maracaí 93/94 (0,06 e 0,53), exceto para as testemunhas em Maracaí. Os valores de ordem intermediária obtidos para as gerações $F_{2[4]}$ e $F_{3: 2[4]}$ das populações $(0,64 ; 0,53)$, sugerem que o caráter valor agronômico não deve ser utilizado como um único referencial para seleção de genótipos mais produtivos. Valores superiores entre VA x PG são descritos por PACOVA (1992) com progênies derivadas de cruzamentos envolvendo materiais não adaptados.

As outras correlações com produtividade de grãos, mencionadas anteriormente (itens 4.5.1.1 a 4.5.1.4), não demonstraram valores significativos para as populações, embora aspectos como a maturidade excessivamente tardia tenham de ser tomados em conta, por inviabilizar o cultivo da "safrinha"; promovendo ainda, maiores custos produtivos pelo maior tempo de exposição destas plantas à intempéries e ao ataque de pragas e doenças. 


\subsubsection{Correlações fenotípicas de Pearson}

Correlações fenotípicas simples entre seis caracteres, tomados dois a dois, para as 45 populações e para as 4 testemunhas em dois ambientes estão apresentadas nas Tabelas 30 e 31 (resumo).

Estas correlações são de importância prática para o melhorista, pois demonstram dentro de cada cruzamento (Tabela 30), como deve ser orientada a seleção de progênies, para obtenção de maiores ganhos. Correlações estritamente positivas e em sua grande maioria significativas foram descritas para todos as populações para os caracteres NDF x APF, NDF x NDM, APF $x$ NDM, APF x APM e VA x PG, nas duas gerações e/ou locais avaliados.

Para os demais caracteres, associações algumas vezes contraditórias, ou não significativas revelam o cuidado que o melhorista deve ter ao avaliar grande número de populações e progênies de cruzamentos com ampla segregação, evitando generalizações que podem levar a escolhas incorretas ou perda de tempo e dinheiro. Destacam-se neste sentido, associações significativas ora positivas, ora negativas, observadas para NDF x PG e NDM x PG, muitas vezes com respostas divergentes para os dois ambientes nas populações (Tabela 30).

As correlações obtidas com base na média de parcelas (Tabela 29), foram em geral maiores que as obtidas com base em plantas individuais (Tabela 31), sobretudo para associações de caráter mais expressivo, concordando com as afirmações de JOHNSON et al. (1955); BRAVO et al. (1980) e com os resultados obtidos por PACOVA (1992). Porém, notou-se que para associações menores a avaliação com base em plantas individuais elevou a significância dos valores obtidos por apresentar maiores graus de liberdade 
para o teste, embora conclusões similares possam ser obtidas pelo uso dos dois testes.

\subsection{Considerações sobre análises, reunindo-se as gerações $F_{2[4]}$ e $F_{3: 2[4]}$}

\subsubsection{Correlações fenotípicas de Spearman entre os caracteres nas gerações $F_{2[4]}$ e $F_{3: 2[4]}$}

$\mathrm{Na}$ Tabela 32 se encontram as estimativas de correlações fenotípicas de Spearman entre as gerações $F_{2[4]}$ e $F_{3: 2[4]}$, para seis caracteres, baseadas no desempenho de populações e testemunhas nos ambientes de Piracicaba 92/93 e Maracaí 93/94.

Os resultados obtidos em relação à média das testemunhas, revelaram valores positivos e significativos para todos os caracteres. Isto indica que testemunhas mais tardias, altas ou mais produtivas de grãos em Piracicaba, apresentaram tendência semelhante em Maracaí no ano seguinte. Quando estes resultados são verificados para as plantas dentro de cada cultivar, esta associação deixa de existir, pois não havendo segregação dentro dos mesmos, os resultados tendem a ser similares ou erráticos entre os anos avaliados. A exceção foi observada para NDF $(0,46)$ em EMGOPA-301, e para APF, VA e PG em IAC-8, sugerindo que estes cultivares podem não estar homogêneos para estas características. Estes resultados concordam com NASS (1989) e MOREIRA (1992) que também observaram maiores desvios, para algumas destas características, nestes cultivares

Nas populações, as estimativas médias mais elevadas foram obtidas para NDF $(0,77), \operatorname{NDM}(0,70)$, indicando que nestes caracteres a seleção de 
progênies mais tardias em $\mathrm{F}_{2[4]}$ levaria a um aumento no ciclo das populações

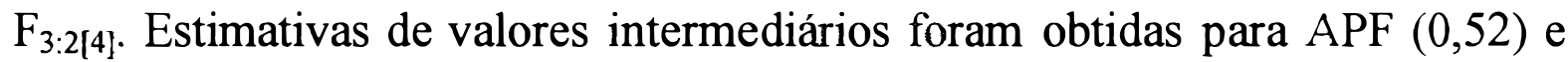
$\operatorname{APM}(0,63)$, e as menores, para VA $(0,13)$ e PG $(0,10)$; caracteres que por possuírem herdabilidades menores que dois primeiros, estão mais sujeitos aos efeitos do acaso e à variações ambientais, além de fatores epistáticos ou de dominância, heterozigosidade e heterogeneidade dentro das populações (LEFFEL \& HANSON; 1961).

As correlações de Spearman para as populações, entre gerações $F_{2[4]}$ e $\mathrm{F}_{3: 2[4]}$, demonstradas neste trabalho foram um pouco superiores do que aquelas (maiores estimativas) observadas por PACOVA (1992) em topocruzamentos com Doko para caracteres como NDF, APF, NDM e APM; porém, pouco menores que as observadas por este autor para os caracteres VA e PG. GOMES (1995), obteve estimativas inferiores para NDM, APM e PG em gerações avançadas $\left(\mathrm{F}_{6}\right.$ e $\left.\mathrm{F}_{7: 6}\right)$ derivadas de cruzamentos entre os mesmos parentais semi-tardios aqui descritos e utilizados.

Para o caráter NDF e NDM todas as correlações foram positivas e significativas, exceto para a população 15 em NDF e para as populações 6 e 8 para NDM. No caráter APF, não foram significativas as correlações entre gerações das populações 6 a 10, 15, 30, 32, 34, 35 e 43. Também não houve significância para as populações 6, 7, 9, 23 e 26 para o caráter APM, indicando que para estas populações a seleção, para este caráter na geração $\mathrm{F}_{2[4]}$, poderia não ser efetiva para aumento do mesmo na geração posterior.

$\mathrm{O}$ caráter VA, demonstrou correlações positivas e significativas para as populações 10, 13, 22, 27, 30, 38 e 42; com estimativas variando de 0,31 a 0,42. Para PG, correlações positivas e de significância entre gerações, foram demonstradas para as populações $21(0,37), 22(0,54)$ e $38(0,32)$. Estes cruzamentos após a seleção em $\mathrm{F}_{2[4]}$ de plantas superiores para VA e PG, 
teriam maior probabilidade de formar populações de plantas $F_{3: 2[4]}$, com maiores valores agronômicos e/ou produtividades de grãos.

A elevada quantidade de estimativas não significativas dentro dos cruzamentos para os caracteres VA e PG, representam a premissa geral da dificuldade de efetuar seleção e previsões em gerações mais precoces de populações com alta produtividade ( FEHR, 1987a; MOREIRA, 1992). Aliase a este fato, que a utilização do método SHDT neste trabalho, resultou em menores graus de liberdade em função do grande número de cruzamentos e menor tamanho efetivo populacional dentro de cada cruzamento.

Diante destes resultados, avalia-se que a seleção para os caracteres NDF, $\mathrm{NDM}$, e mesmo para APF e APM, tende a ser efetiva quando iniciada em $\mathrm{F}_{2[4]}$. Maiores dificuldades são assinaladas na seleção para os caracteres VA ou PG, que pode não demonstrar resultados satisfatórios, quando avaliados em testes com plantas individuais espaçadas, em apenas um ambiente (WEISS et al., 1947).

No entanto, como a seleção em gerações precoces é uma necessidade em programas de seleção recorrente e diante de resultados positivos obtidos por diversos autores (FEHR \& ORTIZ, 1975; KENWORTHY \& BRIM, 1979; BURTON et al., 1990; WERNER \& WILCOX, 1990; ROSE et al., 1992), maiores estudos sobre parâmetros e técnicas de seleção devem ser conduzidos no intuito de se obter sucesso em programas de seleção recorrente para produtividade de grãos. 


\subsubsection{Herdabilidades no sentido restrito}

Herdabilidades no sentido restrito para seis caracteres das 45 populações são apresentadas na Tabela 33. Cumpre lembrar que a estimativa deste parâmetro pode estar viesada devido à presença de variâncias de caráter não aditivo (CAHANER \& HILLEL, 1980; BURTON, 1987), e/ou por interações existentes em uma população que supostamente não se encontra em equilíbrio de "Hardy-Weinberg", devendo ser vista como mais um auxílio na seleção de cruzamentos promissores.

Os valores da herdabilidade no sentido restrito foram bem menores que aqueles obtidas no sentido amplo (Tabelas 10 a 21) para todos os caracteres. Atribuiu-se este resultado ao fato de que no sentido restrito a herdabilidade exprime sobretudo a porção da variância gênica aditiva em relação à variabilidade fenotípica. Nestas gerações iniciais a herdabilidade no sentido restrito contabiliza metade dos efeitos de dominância (VENCOVSKY \& BARRIGA, 1992a), menores efeitos de interações epistáticas do tipo aditiva $\mathrm{X}$ dominante e dominante $\mathrm{x}$ dominante em relação a herdabilidade no sentido amplo. No sentido amplo estes efeitos de dominância e interações, considerados de maneira integral, inflacionam a estimativa, gerando resultados elevados. Segundo CAHANER \& HILLEL (1980) este resultado é esperado, exceto no caso em que a variância não aditiva está ausente.

As médias de herdabilidade para os caracteres NDF $(0,46)$ e NDM $(0,40)$ foram as mais elevadas, demonstrando ser estes mais facilmente alteráveis pela seleção. Valores intermediários foram obtidos para $\operatorname{APM}(0,37)$ e APF $(0,32)$. sendo que para os caracteres VA $(0,08)$ e PG $(0,07)$ foram verificados as menores médias. No geral, esta tendência foi observada para as 
herdabilidades médias obtidas para o sentido amplo, exceto para PG que foi maior que para VA.

As estimativas para NDF, NDM e APM, encontram-se dentro dos valores descritos na literatura. Para os caracteres APF, VA e PG as médias de herdabilidade encontradas neste trabalho foram de ordem inferior às revisadas por PACOVA (1992) e por WILCOX \& MAY (1986) com plantas machoestéreis. Herdabilidade semelhante para PG $(0,06 \pm 0,04 ; p=0,28)$ foram demonstradas por WERNER \& WILCOX (1990) em três ciclos de seleção recorrente para produtividade de grãos, onde o ganho genético estimado de seleção para PG "per-se" foi de 2,8 $\pm 2,2$ g/planta por ciclo. Valores inferiores foram encontrados por PACOVA (1992) para APF e APM, e superiores para NDF, NDM, VA e PG. Nota-se porém, que os resultados obtidos à partir de vários experimentos em situações, populações e objetivos diferenciados, torna difícil comparações entre estas estimativas.

$\mathrm{O}$ caráter VA demonstrou maiores valores de herdabilidades no sentido restrito para as populações $42,13,10,21,38,22$ e 27 , variando entre 0,28 e 0,20. Para PG, maiores herdabilidades foram estimadas para as populações $\mathbf{2 1}$, $22,20,4,23,24,5,40$, com valores oscilando entre 0,26 até 0,16. Estes valores embora relativamente pequenos, indicam maior expectativa de sucesso em $\mathrm{F}_{3: 2[4]}$, com a seleção de plantas de maior VA e PG na geração anterior, para estas populações.

Para os dois ambientes e/ou gerações (Piracicaba 92/93, $\mathrm{F}_{2[4]}$ e Maracaí 93/94, $\mathrm{F}_{3: 2[4]}$ ) elevadas médias produtivas, altos valores agronômicos, maiores estimativas de correlações entre gerações e herdabilidades para PG, foram verificadas nas populações $20,21,22,23$ e 24, podendo-se concluir que estes cruzamentos apresentam grande potencial para gerar progênies superiores em produtividade de grãos e/ou com melhores características agronômicas. Estes 
resultados concordam com aqueles obtidos no item 4.4.2.2, com exceção da população 19, que aqui demonstrou correlações negativas (Tabela 32) entre produtividade nas duas gerações. Destas populações destacaram-se a 21 e 22 com maiores herdabilidades para VA e PG, possuindo maior variabilidade potencial para seleção para ambos os caracteres nestas gerações iniciais.

\subsubsection{Seleção dentro das populações}

Após a identificação dos melhores cruzamentos com potencial de produção de linhagens superiores, a seleção das melhores plantas para posterior recombinação, torna-se de grande importância para formar novas populações para a prática de seleção recorrente. Para tanto, têm-se preconizado o emprego de seleção em gerações precoces, de maneira à reduzir o número de anos por ciclo .

As Tabelas 34, 36, 38, 40 e 42, demonstram o número de plantas (Np) e médias ( $\bar{\mu} \mathrm{p}$ ) das populações originais $\mathrm{F}_{3: 2[4]}$ (sem seleção), número de plantas (Ns) $F_{2[4]}: F_{3: 2[4]}$ selecionadas, médias $(\bar{\mu} \mathrm{s})$ e percentuais (\%s) das novas populações $\mathrm{F}_{3: 2[4]}$ selecionadas e ganhos genéticos em g/planta $(\Delta \mathrm{Gr})$ ou percentuais $(\Delta \mathrm{Gr} \%)$, obtidos após a seleção dentro da geração $F_{2[4]}$, para os caracteres PG, VA, NDM ou combinações destes. Alterações indiretas, observadas nos demais caracteres em $\mathrm{F}_{3: 2[4]}$, ocasionadas por esta seleção podem ser observadas nas Tabelas 35, 37, 39, 41 e 43. 


\subsubsection{Seleção para Produtividade de Grãos (PG)}

Pela Tabela 34, nota-se pelo critério de seleção para PG, que, em média, $25 \%$ das plantas $F_{3: 2[4]}$ foram selecionadas por possuírem parentais $F_{2[4]}$ com PG maior que $141 \mathrm{~g} /$ planta (testemunha mais produtiva em Piracicaba $=$ Cristalina), proporcionando um ganho genético médio de 4,61 gramas por planta (7,85\% da média original), o qual foi superior aos $2,8 \pm 2,2 \mathrm{~g} /$ planta obtidos por WERNER \& WILCOX (1990) para produtividade "per-se".

$\mathrm{O}$ valor de 4,61 g/planta quando extrapolado em ganho por área atinge $72,03 \mathrm{Kg} / \mathrm{ha}$, sendo inferior aos progressos de $134 \mathrm{Kg} / \mathrm{ha} /$ ciclo relatados por KENWORTHY \& BRIM (1979) e de $76,6 \mathrm{Kg} / \mathrm{ha} /$ ano encontrados por BURTON et al. (1990); porém, muito superior aos $24 \mathrm{Kg} / \mathrm{ha}$ obtidos para genótipos tardios por SUMARNO \& FEHR (1982), todos com seleção recorrente em soja.

As maiores médias das populações $F_{3: 2[4]}$ selecionadas foram obtidas para os cruzamentos $22,41,21,23,34,20,24$, com respectivas médias decrescendo de 87,06 até $72,93 \mathrm{~g} /$ planta, sendo superiores ou iguais a média das testemunhas em Maracaí -SP (Tabela 21). Ganhos acima de 10 gramas por planta (Tabela 35, Figura 2), foram obtidos sómente para as cruzamentos 12, $22,30,31,32,37$ e 41.

Ganhos negativos obtidos por diversas populações podem estar relacionados com a perda de alelos importantes devido a seleção na presença de ligações desfavoráveis, à interações do tipo genótipo por ambiente, fatores genéticos relacionados à dominância e/ou interações epistáticas (HANSON \& HAYMAN, 1963; PIPER \& FEHR, 1987 e FOULLLUX \& BANNEROT, 1988), sendo este fato previsto pelos baixos valores das correlações fenotípicas de Spearman, para o caráter PG nas duas gerações (Tabela 29). 
As alterações ocorridas nas médias dos demais caracteres pela seleção (Tabela 32) revelam um aumento médio de 2 e 3 dias para NDF e para NDM, 3,03 e 3,34 cm para APF e para APM e 0,12 para VA. Algumas populações como as de número 1, 8, 9 e 10 aumentaram substancialmente seus ciclos em mais de 10 dias. Um aumento de três dias na maturidade das populações no primeiro ciclo de seleção torna-se preocupante, pois considerando que um programa de seleção recorrente envolve vários ciclos de seleção e recombinação de genótipos superiores, a maturidade destas populações poderia aumentar consideravelmente.

\subsubsection{Seleção para Valor Agronômico (VA)}

A seleção de plantas $\mathrm{F}_{2[4]}$ para valor agronômico (VA) boas e excelentes (VA $\geq 4$; Tabela 36) não demonstrou, isoladamente, ser uma melhor opção que seleção "per-se" para PG, uma vez que o ganho médio obtido foi de apenas $1,02 \mathrm{~g} /$ planta ou $15,94 \mathrm{~kg} / \mathrm{ha}(1,73 \%)$. Este resultado já era esperado devido aos valores médios de correlação entre VA x PG na geração $F_{2[4]}$ (Tabelas 29 e 31). Deve-se ressaltar que a avaliação para VA, leva em conta outros caracteres não relacionados diretamente com produção de grãos, sendo esperado um menor ganho genético quando utilizada como único indicativo na seleção para produtividade de grãos.

As maiores médias foram obtidas para as seguintes populações $F_{3: 2[4]}$ selecionadas: 41, 21, 34, 23 e 22, com respectivas médias decrescendo de 86,08 até 76,08 g/planta, sendo superiores a média das testemunhas em Maracaí-SP (Tabela 21). Apenas o cruzamento 41 obteve ganho superior à 10 gramas por planta, sendo observado também grande número de ganhos 
negativos. As conseqüências da seleção (Tabela 37), foram um aumento de $1 \mathrm{e}$ 2 dias para NDF e NDM; 2,03 e 2,44 cm para APF e para APM, e 0,07 no VA. O aumento de 0,07 no valor médio do VA em relação a seleção "per-se" para PG (aumento de 0,12 no VA; Tabela 35) é resultado da somatória dos efeitos da correlação positiva entre os caracteres VA e PG (Tabelas 29, 30 e 31) e o efeito de uma seleção mais branda para VA (59 \% das plantas selecionadas). Uma seleção em $\mathrm{F}_{2[4]}$ somente para plantas com VA excelente $(\mathrm{VA}=5 ; 12 \%$ das plantas selecionadas) formeceu aumento real médio de 0,14 na média do VA das populações e pequeno acréscimo no valor de $\mathrm{PG}$ em 0,94 g/planta (valores para cada população não apresentados neste trabalho).

Estes resultados sugerem que a seleção visual, embora tenha apresentado resultados positivos na média da maioria das populações, não deve ser utilizado como único critério de seleção de progênies superiores em gerações precoces, tornando-se importante no aspecto de descartar progênies inferiores (HANSON et al., 1962). Resultados contraditórios, revelam necessidade de mais trabalhos envolvendo a seleção visual em programas de seleção recorrente (BYTH et al., 1969; WILCOX \& SCHAPAUGH, 1980; GARLAND \& FEHR, 1981).

\subsubsection{Seleção conjunta para Produtividade de Grãos + Valor Agronômico (PG + VA)}

Com a seleção praticada em $\mathrm{F}_{2[4]}$ para os caracteres valor agronômico e produtividade de grãos (VA $\geq 4$ e PG > 141 g/planta; Tabela 38), obteve-se maior eficiência na seleção que para estes caracteres isolados. Foram verificados ganhos médios de 4,87 gramas por planta ou $76,09 \mathrm{~kg} / \mathrm{ha}(8,29 \%)$, sendo que nove populações obtiveram ganhos superiores a $10 \mathrm{~g} /$ planta (Figura 
3). Estes dados mostram que a utilização do valor agronômico como característica auxiliar na seleção para produtividade de grãos, proporcionou um pequeno progresso $(0,26 \mathrm{~g} /$ planta, $0,44 \%)$ em relação a seleção "per-se" para PG na média das populações. Valores de PG superiores a média das testemunhas em Maracai (Tabela 21) foram obtidas para as populações $F_{3: 2[4]}$ selecionadas $41,22,21,23,32,34,24$ e 20, com respectivas médias decrescendo de 125,96 até $73,70 \mathrm{~g} /$ planta.

Embora a diferença de ganho na média das populações $(0,26 \mathrm{~g} / \mathrm{planta})$ em relação a seleção exclusiva para $P G$ pareça pequena, o aumento na média das populações em 0,14 para VA, refletem a importância de correlações fenotipicas e genéticas positivas (Tabelas 29, 30 e 31) entre estes dois caracteres, proporcionando uma melhoria $(3,6$ \%) das qualidades agronômicas das populações. As outras características tiveram incrementos da ordem de 2 e 3 dias para NDF e NDM, 3,29 e 3,65 cm para APF e para APM, considerando-se a média das populações.

\subsubsection{Seleção conjunta para Produtividade de Grãos + Número de Dias para a Maturidade (PG + NDM)}

A seleção em $\mathrm{F}_{2[4]}$ de plantas com número de dias para a maturidade (NDM) menor ou igual a 162 dias, mais produtividade de grãos (PG) maior que $141 \mathrm{~g} /$ planta, elevou a produtividade das populações em média 6,62 g/planta ou 103,44 kg/ha (11,27\%), com ganhos superiores à $10 \mathrm{~g} /$ planta em 13 populações (Tabela 40, Figura 5). Isto demonstra a influência do caráter NDM, na produtividade das populações. Este fato pode ser atribuido ao princípio que plantas com ciclo muito longo tiveram a produtividade reduzida 
devido ao maior tempo de exposição no campo à estresses ambientais ocasionados por déficit hídrico (Figura 7; item 4.1.2), ventos, frio, e ataque de doenças e pragas. Correlações fenotípicas e genéticas negativas entre NDM x PG, embora não significativas, sugeriram uma resposta neste sentido (Tabelas $29,30$ e 31$)$.

As maiores médias das populações $F_{3: 2[4]}$ selecionadas foram obtidas para as populações $17,22,21,41,23,20,34,6$, e 24, com respectivas médias decrescendo de 94,66 até 72,93 g/planta, sendo superiores ou iguais a média das 4 testemunhas em Maracaí -SP (Tabela 21).

Respostas da seleção para NDM e PG nos outros caracteres, demonstraram na média das populações nenhuma alteração para NDF, redução de um dia para NDM, acréscimo de 1,55 e 2,32 cm para APF e APM e aumento de 0,17 para VA. Algumas populações (1,5 e 17) tiveram seu ciclo reduzidos em mais de 10 dias; demonstrando a importância da avaliação e utilização de associações existentes entre caracteres durante a seleção. O maior aumento na média das populações, e conseqüente ganho genético, em relação à seleção para produtividade "per-se", sem causar mudanças drásticas na maturidade das populações, foi preconizado por WERNER \& WILCOX (1990), com seleção baseada em um índice de produtividade com regressão para maturidade, conseguindo ganhos de $5,7 \mathrm{~g} /$ planta por ciclo, o dobro da seleção para produtividade "per-se". 


\subsubsection{Seleção conjunta para Produtividade de Grãos, Valor agronômico e Número de Dias para a Maturidade $(\mathrm{PG}+\mathrm{VA}$ + NDM)}

A seleção incluindo os caracteres produtividade de grãos, número de dias para a maturidade e valor agronômico ( $P G+V A+N D M)$ foi a mais efetiva de todas, proporcionando ganhos médios de 7,08 g/planta ou 110,47 $\mathrm{kg} /$ ha $(12,05 \%)$, elevando a média das populações de $58,74 \mathrm{~g} /$ planta para $65,82 \mathrm{~g} /$ planta. Vinte e dois por cento das populações selecionadas para estas características, tiveram desempenho superior em relação a média das testemunhas em Maracaí-SP (Tabela 21), sendo estas relacionadas à seguir: 41, 17, 22, 21, 23, 32, 20, 6, 34 e 24 (produtividades entre 125,96 e 74,23 g/planta). Ganhos superiores à $10 \mathrm{~g} /$ planta ou $156,3 \mathrm{~kg} / \mathrm{ha}$, portanto superiores aos obtidos por KENWORTH \& BRIM (1979), foram obtidos em 15 das 45 populações (Tabela 42, Figura 6). Soma-se a este resultado, o menor número de populações com ganhos negativos (10), demonstrando que a união destes três caracteres proporcionou melhores resultados de seleção.

Foram verificados acréscimos nas médias dos caracteres nas populações após seleção (Tabela 43), em um dia para NDF, um dia para NDM, 1,84 e 2,39 $\mathrm{cm}$ na altura no florescimento e maturidade e 0,19 para o valor agronômico. Houve aumentos de mais de 10 dias na maturidade das populações 38 e 41 , e reduções superiores ou iguais a 10 dias na maturidade das populações $\mathbf{1 , 5}, 11$ e 17. De acordo com estes resultados nota-se que exceto para alguns casos, em média não houve alterações excessivas nos valores de caracteres como altura, ciclo ou valor agronômico.

Um aspecto interessante da seleção indexada, foi observado para as populações 17 e 41, que apresentaram ganhos surpreendentes quando 
selecionadas para estes caracteres. A população 17 não apresentou potencial produtivo elevado em nenhuma das duas gerações (Tabelas 26 e 27). No entanto quando selecionada para VA (Tabela 36; Figura 3), apresentou 21 plantas boas e excelentes em $F_{3: 2[4]}$. Selecionada para PG e para VA + PG, apresentou apenas 5 plantas com desempenhos superiores à Cristalina (melhor testemunha), no entanto os ganhos não foram ainda tão expressivos (Tabelas 34, 38 e Figuras 2 e 3). Porém quando utilizou-se como critério NDM + PG ou $\mathrm{NDM}+\mathrm{VA}+\mathrm{PG}$ (Tabelas 39 e 42; Figuras 5 e 6), demonstrou uma progênie apresentando ganhos próximos a $55 \mathrm{~g} / \mathrm{planta}$.

O desempenho observado na população 17 , com a inclusão do caráter NDM, comparou-se ao obtido para a 41 com relação ao caráter VA, onde a inclusão deste caráter no índice de seleção (Tabelas 36, 38 e 41,; Figuras 3, 4 e 6), também revelou a existência de uma progênie com enorme potencial produtivo. Estes resultados sugerem que a presença destas progênies, nestas populações, pode ser resultado da recombinação entre combinações alélicas extremamente favoráveis, elevando suas médias, tornando-as transgressivas em relação à seus parentais e testemunhas mais produtivas nas duas gerações.

\subsubsection{Considerações finais}

A partir dos dados obtidos na Tabela 42, observou-se que após seleção considerando-se os caracteres número de dias para a maturidade, valor agronômico e produtividade de grãos ( $\mathrm{PG}+\mathrm{VA}+\mathrm{NDM})$, destacaram-se as populações 21 e 22 com médias pouco maiores que os dois parentais e/ou testemunhas mais produtivos do ensaio. Estes dados aliados a valores agronômicos elevados (Tabelas 26 e 27), ciclos médios (130 a 140 dias), 
presença de segregantes transgressivos para PG nas duas gerações (Tabelas 20 e 21), herdabilidades no sentido amplo e valores de b superiores a unidade (Tabelas 20 e 21), maiores valores de herdabilidades no sentido restrito para VA e PG (Tabela 33), valores altos de correlações de Spearman entre gerações altos para PG e VA (Tabela 32), indicam que estas populações são as de maior potencial para obtenção de linhagens altamente produtivas e com elevado valor agronômico.

Outras populações que também se destacaram neste trabalho foram as de número 20,23 e 24, pois somam várias destas características relacionadas no parágrafo anterior, com médias elevadas antes e após a seleção. Estes dados sugerem que IAC-4 e GO79-1039, possuem boa capacidade de combinação, entre si e com vários outros parentais presentes neste trabalho. Aparentemente, interações do tipo genótipo por ambiente (verificada para os parentais; Tabela 24) e possíveis interações epistáticas do tipo aditiva $x$ dominante e dominante $x$ dominante, além de efeitos de dominância, impediram de identificar com certeza, outras populações que poderiam também apresentar desempenho superior. GOMES (1995), encontrou elevado percentual de progênies $F_{7: 6}$, derivadas de cruzamentos com IAC-4, com ganho genético positivo, destacando-se IAC-4 x IAC-9 na possibilidade de seleção de progênies superiores.

Aparentemente, a maior produtividade do parental GO79-1039 em relação a IAC-4 em Piracicaba (embora com diferenças não significativas), e a inversão deste resultado (com diferenças significativas) em Maracaí, sugerem uma possível existência de genes complementares para produtividade, com expressão diferenciada em cada ambiente, nestes dois cultivares (Tabela 25). 


\section{CONCLUSÕES}

Os resultados obtidos nestas condições experimentais, permitem concluir que:

a) Os parentais mostraram interação de genótipos por ambientes para os seguintes caracteres: ciclo (número de dias para florescimento $=$ NDF e número de dias para maturidade NDM), valor agronômico (VA) e produtividade de grãos (PG). Destacaram-se os parentais: Cristalina, EMGOPA-301, IAC-9 e SS-1, nos dois ambientes avaliados, com elevados valores de PG e VA.

b) O método SHDT ("Single Hill Descent Thinned") foi eficiente para conduzir grande número de populações com tamanho efetivo adequado $(\mathrm{N}=$ 39 plantas em média) e exigência de pequeno número de sementes de cada genótipo e área experimental.

c) Cruzamentos quádruplos entre parentais semi-tardios e tardios proporcionaram elevada variabilidade genética nas populações obtidas, produzindo segregantes superiores em VA e PG.

d) Para a maioria das populações, não houve redução da variabilidade genética entre as gerações $F_{2[4]}$ e $F_{3: 2[4]}$. 
e) Antes e pós-seleção, destacaram as populações obtidas pelos seguintes cruzamentos quádruplos:

$$
\begin{aligned}
& \mathbf{2 0}=(\text { IAC-4 x IAC-8) X (GO79-1039 x Numbaíra }) \\
& \mathbf{2 1}=(\text { IAC-4 } \times \text { IAC-9 }) \times(\text { GO79-1039 } \times \text { Paranagoiana }) \\
& \mathbf{2 2}=(\text { IAC-4 x IAC-11) X (GO79-1039 } \times \text { Timbira }) \\
& \mathbf{2 3}=(\text { IAC-4 } \times \text { Santa Rosa }) \text { X (GO79-1039 x Tropical }) \\
& \mathbf{2 4}=(\text { IAC-4 } \times \text { SS-1 }) \times(\text { GO79-1039 } \times \text { White Biloxi })
\end{aligned}
$$

f) A seleção precoce de plantas em $\mathrm{F}_{2[4]}$, foi mais eficiente quando os caracteres PG, VA e NDM foram combinados em um índice de seleção principalmente para as populações $41,17,22,21,23,32,20,6,34$, e 24, em ordem decrescente de PG. 


\section{REFERÊNCIAS BIBLIOGRÁFICAS}

ALLIPRANDINI, L.F. Estudo dos efeitos ambientais, estabilidade, adaptabilidade e ganho genético em linhagens de soja (Glycine max (L.) Merrill) no Estado do Paraná. Londrina, 1992. 122 p. (Mestrado - Universidade Estadual de Londrina/EMBRAPA/IAPAR).

ALLIPRANDINI, L.F.; TOLEDO, J.F.F.; FONSECA JUNIOR., N.S.; KIIHL, R.A.S.; ALMEIDA, L.A. Ganho genético em soja no Estado do Paraná, via melhoramento, no período de 1985/86 a 1989/90. Pesquisa Agropecuária Brasileira, Brasília, 28 (4): 489-97, 1993.

ALLIPRANDINI, L.F.; TOLEDO, J.F.F.; FONSECA JUNIOR., N.; ALMEIDA, L.A.; KIIHL, R.A.S. Efeitos da interação genótipo $\mathrm{x}$ ambiente sobre a produtividade da soja no Estado do Paraná. Pesquisa Agropecuária Brasileira, Brasília, 29 (9): 1433-1444, 1994.

ALMEIDA, L.A.; KASTER, M.; KIIHL, R.A.S. Caracterização das cultivares de soja recomendadas no Brasil, para o ano agrícola 1991/92. Londrina, EMBRAPA/CNPSo, 1991a.

ALMEIDA, L.A.; KASTER, M.; KIIHL, R.A.S. Informações complementares das cultivares de soja recomendadas no Brasil, para o ano agrícola 1991/92. Londrina, EMBRAPA/CNPSo, $1991 \mathrm{~b}$.

ANAND, S.C. \& TORRIE, J.H. Heritability of yield and other traits and interrelationships among traits in the $F_{3}$ and $F_{4}$ generations of three soybean crosses. Crop Science, Madison, 3: 508-11, 1963.

AVEY, D.P.; OHM, H.W.; PATTERSON, F.L.; NYQUIST, W.E. Three cycles of simple recurrent selection for early heading in winter wheat. Crop Science, Madison, 22: 908-12, 1982. 
BERNARD, R.L. Two genes affecting stem termination in soybeans. Science, Madison, 12: 235-239, 1972.

BOERMA, H.R. \& COOPER, R.L. Effectiveness of early generation yield selection in soybeans using combined generations means. Agronomy Abstracts, Davis, p.23, 1972.

BOERMA, H.R. \& COOPER, R.L. Comparison of three selection procedures for yield in soybeans. Crop Science, Madison, 15:225-29, 1975.

BONETTI, P.L. Cultivares e seu melhoramento genético. In: VERNETTI, F.J., coord., Soja, Genética e Melhoramento. Campinas, Fundação Cargill, 1983. cap. 9 , p.741-800.

BOS, I. More arguments against intermating $\mathrm{F}_{2}$ plants of a self-fertilizing crop. Euphytica, Wageningen, 26: 33-46, 1977.

BRANSON, C.V. \& FREY, K.J. Recurrent selection for great oil content in oats. Crop Science, Madison, 29: 1382-7, 1989.

BRAVO, J.A.; FEHR, W.R.; RODRIGUEZ de CIANZIO, S. Use of pod width for indirect selection of seed weight in soybeans. Crop Science, Madison, 20: 507-10, 1980.

BRIM, C.A. Male sterility in recurrent selection. In: HILL. D., ed. World Soybean Research. Danville, The Interstate Printers \& Publishers, 1976. p.262-5.

BRIM, C.A. Quantitative genetics and breeding. In: CALDWELL, B.E., ed. Soybeans; improvement, production and uses. Madison, American Society of Agronomy, 1973. Cap.5, p.155-86.

BRIM, C.A. \& BURTON, J.W. Recurrent selection in soybeans. II. Selection for increased percent protein in seeds. Crop Science, Madison, 19: 494-8, 1979.

BRIM, C.A. \& COCKERHAM, C.C. Inheritance of quantitative characters in soybeans. Crop Science, Madison, 1: 187-90, 1961.

BRIM, C.A. \& STUBER, C.W. Application of male sterility to recurrent selection schemes in soybeans. Crop Science, Madison, 13: 528-30, 1973. 
BURTON, J.W. Quantitative genetics: results relevant to soybean breeding. In: WILCOX, J.R., ed. Soybeans; improvement, production and uses. 2.ed. Madison, ASA/CSSA/SSSA, 1987. Cap.6, p.211-47.

BURTON, J.W. \& BRIM, C.A. Recurrent selection in soybeans: III. Selection for increased percent oil in seeds. Crop Science, Madison, 21: 31-4, 1981.

BURTON, J.W.; KOINANGE, E.M.K.; BRIM, C.A. Recurrent selfed progeny selection for yield in soybean using male sterility. Crop Science, Madison, 30: $1222-6,1990$.

BURTON, J.W.; WILSON, R.F.; BRIM, C.A. Recurrent selection in soybeans. IV. Selection for increased oleic acid percentage in seed oil. Crop Science, Madison, 23: 744-7, 1983.

BYTH, D.E.; WEBER, C.R.; CALDWELL, B.E. Correlated truncation selection for yield in soybeans. Crop Science, Madison, 9: 699-702, 1969.

CAHANER, A. \& HILLEL, J. Estimating heritability and genetic correlation between traits from generations $F_{2}$ and $F_{3}$ of self-fertilizing species: a comparison of three methods. Theoretical and Applied Genetics, Berlin, 58: $33-8,1980$.

CARNIELLI, A.; VELLO, N.A. Parcelas em fileiras de tamanho reduzido ou em covas na avaliação da produtividade e demais características no melhoramento da soja. Dourados: EMBRAPA-UEPAE Dourados, 1992. 22p. (EMBRAPA-UEPAE Dourados. Boletim de Pesquisa, 6).

CECON, P.R. Herança de alguns caracteres de soja (Glycine max (L.) Merrill), nas gerações $\mathrm{F}_{2}$ e $\mathrm{F}_{3}$ de cruzamentos fatoriais. Viçosa, 1983. 58 p. (MestradoUniversidade Federal de Viçosa).

COCKERHAM, C.C. Covariances of relatives from self-fertilization. Science, Madison, 23: 1177-80, 1983.

Crop

COMPTON, W.A. Recurrent selection in self-pollinated crops without extensive crossing. Crop Science, Madison, 8: 773, 1968. 
COMPTON, W.A. Heterosis and additive $\mathrm{x}$ additive epistasis. Soybean Genetics Newsletter, Ames, 4: 60-2, 1977.

DELANEY, D.E. \& BLISS, F.A. Selection for increased percentage phaseolin in common bean. 1. Comparison of selection for seed protein alleles and $S_{1}$ family recurrent selection. Theoretical and Applied Genetics, Berlin, 81, 301-5, 1991a.

DELANEY, D.E. \& BLISS, F.A. Selection for increased percentage phaseolin in common bean. 2. Changes in frequency of seed protein alleles with $S_{1}$ family recurrent selection. Theoretical and Applied Genetics, Berlin, 81, 306-11, 1991b.

DESTRO, D. Capacidade de combinação de genótipos de soja [Glycine max (L.) Merrill] apropriados para o consumo humano. Piracicaba, 1991. 158 p. (Doutorado - Escola Superior de Agricultura "Luiz de Queiroz" / USP).

DUVICK, D.M. Genetic diversity in major farm crops on the farm and reserve. Economic Botany, New York, 38 (2): 161-178, 1984.

EMBRAPA. Centro Nacional de Pesquisa de Soja (Londrina, PR). Recomendações técnicas para a cultura da soja na região central do Brasil - 1994/95. Londrina, 1994. 127 p. (EMBRAPA-CNPSo. Documentos, 77).

EMBRAPA. Centro Nacional de Pesquisa de Soja (Londrina, PR). Recomendações técnicas para a cultura da soja na região central do Brasil - 1995/96. Londrina, 1995. 149 p. (EMBRAPA-CNPSo. Documentos, 88).

ERICKSON, E.H. Effect of honey bees on yield of three soybean cultivars. Crop Science, Madison, 15: 84-6, 1975.

FALCONER, D.S. Introdução à genética quantitativa. Viçosa, UFV, 1987. 279 p.

FARIAS NETO, J.T. Comportamento e variabilidade de genótipos de soja (Glycine max (L.) Merrill) em cultivos de verão e inverno. Piracicaba, 1987. 87 p. (Mestrado - Escola Superior de Agricultura "Luiz de Queiroz"/USP). 
FEHR, W.R. Recurrent selection for yield in soybeans. American Society Agronomy Abstracts, p. 52, 1974.

FEHR, W.R. Breeding. In: NORMAN, A.G., ed. Soybean, physiology, agronomy and utilization. New York, Academic Press, 1978. p. 119-55.

FEHR, W.R. Breeding methods for cultivar development. In: WILCOX, J.R., ed. Soybeans: improvement, production, and uses. 2.ed. Madison, ASA/CSSA/SSSA, 1987a. cap.7, p.249-93.

FEHR, W.R. Recurrent Selection. In: ___ ed. Principles of cultivar development. New York, Macmillan, 1987b. cap. 15, V.1, p. 172-98.

FEHR, W.R. Soybean. In: ed. Principles of cultivar development. New York, Macmillan, 1987c. cap. 14, V.2, p. 533-76.

FEHR, W.R. \& CAVINESS, C.E. Stages of soybean development. Ames, IOWA State University of Science and Technology, 1977. 12 p. (Special Report, 80).

FEHR, W.R. \& ORTIZ, L.B. Recurrent selection for yield in soybeans. Journal Agriculture of the University of Puerto Rico, Rio Piedras, 59: 222-32, 1975.

FOUILLOUX, G. \& BANNEROT, H. Selection methods in the common bean (Phaseolus vulgaris). In: GEPTS, P., ed. Genetic resources of phaseolus beans. Dordrecht, Kluwer, 1988. p.503-42.

FREIRE FILHO, F.R. Análise genética de um dialelo entre genótipos precoces de soja [Glycine max (L.) Merrill]. Piracicaba, 1988. 224p. (Doutorado - Escola Superior de Agricultura "Luiz de Queiroz"/(USP).

FREY, K.J. Breeding concepts and techniques for self-pollinated crops. Egyptian Journal of Genetics and Cytology, Giza, 5: 184-206, 1976.

FREY, K.J. \& HORNER, T. Heritability in standart units. Agronomy Journal, Madison, 49(2): 59-62, 1957.

GALLAIS, A. Amélioration de l'efficacité des schémas de sélection récurrente. Annales Amélioration des Plantes, Paris, 27: 477-81, 1977. 
GARLAND, M.L. \& FEHR, W.R. Selection for agronomic characters in hill and row plots of soybeans. Crop Science, Madison, 21: 591-5, 1981.

GATES, C.E.; WEBER, C.R.; HORNER, T.W. A linkage study of quantitative characters in a soybean cross. Agronomy Journal, Madison, 52: 45-9, 1960.

GILIOLI, J.L.; ALMEIDA, L.A.; KIIHL, R.A.S. Aspectos sobre o melhoramento da soja [Glycine $\max$ (L.) Merrill]. Londrina, EMBRAPA/CNPSo, 1980. 20 p.

GOLDRINGER, I. \& BRABANT, P. Sélection récurrente chez les autogames pour l' amélioration des variétés lignées pures: une revue bibliographique. II. Agronomie, Paris, 13: 561-77, 1993.

GOMES, R.L.F. Análise genética de progênies $F_{6}$ e $F_{7: 6}$ de soja obtidas de cruzamentos dialélicos. Piracicaba, 1995. 140 p. (Doutorado - Escola Superior de Agricultura "Luiz de Queiroz"/USP).

GUIMARAES E.P. \& FEHR, W.R. Alternative strategies of recurrent selection for seed yield of soybean. Euphytica, Wageningen, 40: 111-20, 1989.

GUPTON, C.L. Phenotypic recurrent selection for increased leaf weight and decreased alkaloid content of Burley Tobacco. Crop Science, Madison, 21: 921-5, 1981.

HANSON, W.D. The breakup of initial linkage blocks under selected mating systems. Genetics, Princeton, 44: 857-68, 1959.

HANSON, W.D. Phenotypic recurrent selection for modified reproductive period in soybean. Crop Science, Madison, 32: 968-72, 1992.

HANSON, W.D. \& HAYMAN, B.I. Linkage effects on additive genetic variance among homozygous lines arising from the cross between two homozygous parents. Genetics, Princeton, 48: 755-66, 1963.

HANSON, W.D.; LEFFEL, R.C.; JOHNSON, H.W. Visual discrimination for yield among soybean phenotypes. Crop Science, Madison, 2: 93-6, 1962. 
HANSON, W.D.; PROBST, A.H.; CALDWELL, B.E. Evaluation of a population of soybean genotypes with implications for improving selfpollinated crops. Crop Science, Madison, 7: 99-103, 1967.

HELMS, T.C.; ORF, J.H. \& SCOTT, R.A. Actual yield advance from selection for visual score and yield. Canadian Journal of Plant Science, Ottawa, 75(1): 187-9, 1995.

HIROMOTO, D.M. \& VELLO, N.A. The genetic base of Brazilian soybean (Glycine $\max$ (L.) Merrill) cultivars. Revista Brasileira de Genética, Ribeirão Preto, 9(2): 295-306, 1986.

HOMEM DE MELO, F. Prejuízo no campo é de $21 \%$. Folha de São Paulo, São Paulo, 28 mar, 1995. Guia da safra, p.3.

JENSEN, N.F. A diallel selective mating system for cereal breeding. Crop Science, Madison, 10: 629-35, 1970.

JOHNSON, H.W.; ROBINSON, H.F.; COMSTOCK, R.E. Genotypic and Phenotypic correlations in soybeans and their implications in selection. Agronomy Journal, Madison, 47: 477-83, 1955.

KENWORTHY, W.J. \& BRIM, C.A. Recurrent selection in soybeans. I. Seed Yield. Crop Science, Madison, 19:315-8, 1979.

KHADR, F.H. \& FREY, K.J. Effectiveness of recurrent selection in oat breeding (Avena sativa L.). Crop Science, Madison, 5: 349-54, 1965.

KMHL, R.A.S. \& GARCIA, A. The use of long-juvenile trait in breeding soybean cultivars. In: WORLD SOYBEAN RESEARCH CONFERENCE, 4., Buenos Aires, 1989. Proceedings. Buenos Aires, AASOJA, 1989. V.2, p.994-1000.

KWON, S.H. \& TORRIE, J.H. Heritability of and interrelationships among traits of two soybean populations. Crop Science, Madison, 4: 196-8, 1964.

LEFFEL, R.C. \& HANSON, W.D. Early generation testing of diallel crosses of soybeans. Crop Science, Madison, 1(3): 169-74, 1961. 
LÖFFLER, C.M.; BUSCH, R.H.; WIERSMA, J.V. Recurrent selection for grain protein percentage in hard red spring wheat. Crop Science, Madison, 23: 1097-101, 1983.

LUEDDERS, V.D.; DUCLOS, L.A.; MATSON, A.L. Bulk, pedigree, and early generation testing breeding methods compared in soybeans. Crop Science, Madison, 13: 363-4, 1973.

MACHADO, E.C. Disponibilidade de Água como fator de crescimento da planta. In: MIYASAKA, S. \& MEDINA, J.C., ed. A soja no Brasil. Campinas, ITAL, 1981. p.153-6.

MACNEAL, F.H.; McGUIRE, C.F.; BERG, M.A. Recurrent selection for grain protein content in spring wheat. Crop Science, Madison, 18: 779-82, 1978.

MAHMUD, I. \& KRAMER, H.H. Segregation for yield, height and maturity following a soybean cross. Agronomy Journal, Madison, 43: 605-9, 1951.

MATZINGER, D.F. \& WERNSMAN, E.A. Four cycles of mass selection in a synthetic variety of an autogamous species Nicotiniana tabacum L. Crop Science, Madison, 8: 239-43, 1968.

MLLER, J.E. \& FEHR, W.R. Direct and Indirect recurrent selection for protein in soybeans. Crop Science, Madison, 19: 101-6, 1979.

MIRANDA, M.A.C. Seleção recorrente divergente para peso de sementes e porcentagem de óleo em soja com o uso de machoesterilidade genética. Piracicaba, 1994. 112 p. (Doutorado - Escola Superior de Agricultura "Luiz de Queiroz"/USP).

MIYASAKA, S. \& MEDINA, J.C. A soja no Brasil. Campinas, ITAL, 1981. p.17-64.

MOREIRA, R.M.P. Predição do comportamento de cruzamentos dialélicos de soja avaliados na geração $F_{3}$ em cultivo de inverno. Piracicaba, 1992. 95 p. (Mestrado - Escola Superior de Agricultura "Luiz de Queiroz"/USP).

MÜLLER, L. Morfologia Anatomia e Desenvolvimento. In: MIYASAKA, S. \& MEDINA, J.C., ed. A soja no Brasil. Campinas, ITAL, 1981. p.73-108, 
NASS, L.L. Potencialidade de genótipos de soja (Glycine max (L.) Merrill) para cultivo de inverno avaliada por cruzamentos dialélicos. Piracicaba, 1989. 112 p. (Mestrado - Escola Superior de Agricultura "Luiz de Queiroz"/USP).

NELSON, R.L. Defining the seed-filling period in soybeans to predict yield. Crop Science, Madison, 26: 132-5, 1986.

PACOVA, B.E.V. Análise genética de progênies segregantes de soja apropriada para o consumo humano. Piracicaba, 1992. 217 p. (Doutorado - Escola Superior de Agricultura "Luiz de Queiroz"/USP).

PAVONI, J.C. Desarrolo de poblaciones de trigo con base genética amplia intensamente recombinada. Boletin Genético, Castelar, 15: 59-61, 1989.

PEDERSON, D.G. Arguments against intermating before selection in a selffertilising species. Theoretical and Applied Genetics, Berlin, 45: 157-62, 1974.

PEREIRA, M.B. Progresso imediato e fixação de genes em um método de seleção. Piracicaba, 1980. 125 p. (Mestrado - Escola Superior de Agricultura "Luiz de Queiroz"/USP).

PFEIFFER, T.W. \& VOGT, S.D. Recombination rate and the selfing environment. Soybean Genetics Newsletter, Ames, 6: 138-40, 1989.

PFEIFFER T.W. \& VOGT, S.D. Variability for recombination frequencies in the AP12 soybean population. Crop Science, Madison, 30: 545-9, 1990.

PIMENTEL GOMES, F. Curso de Estatística Experimental. 10 ed. Piracicaba, Nobel, 1982. $430 \mathrm{p}$.

PIPER, T.E. \& FEHR, W.R. Yield improvement in a soybean population by utilizing alternative strategies of recurrent selection. Crop Science, Madison, 27:172-8, 1987.

PROHASKA, K.R. \& FEHR, W.R. Recurrent selection for resistance to iron deficiency chlorosis in soybeans. Crop Science, Madison, 21: 524-6, 1981. 
RAMALHO, M.A.P.; SANTOS, J.B. dos; ZIMMERMANM, M.J.O. Uso da hibridação no melhoramento. In: plantas autógamas. Goiânia, UFG, 1993. cap.9, p.207-40.

RANGEL, P.H.N.; NEVES, P.C.F. Seleção recorrente em arroz irrigado no Brasil. TALLER INTERNATIONAL SOBRE SELEÇÃO RECORRENTE EM ARROZ. Goiânia, 1995. Trabalhos apresentados. Goiânia: EMBRAPA/CNPAF - CIAT/CIRAD-CA/INGER, 1995, p. 114-28.

RAY, J.D.; HINSON, K.; MANKONO, J.E.B.; MALO, M.F. Genetic Control of a Long-Juvenile Trait in Soybean. Crop Science, Madison, 35: 1001-1006, 1995.

ROESSING, A.C. \& GUEDES, L.C.A. Aspectos econômicos do complexo soja: sua participação na economia brasileira e evolução na região do Brasil Central. In: ARANTES, N.E. \& SOUZA, P.I.M., ed. Cultura da soja nos cerrados. Piracicaba, POTAFOS, 1993. p. 1-69.

ROSE, J.L.; BUTLER, D.J.; RYLEY, M.J. Yield improvement in soybeans using recurrent selection. Australian Journal Agricultural Research, 43: 135-44, 1992.

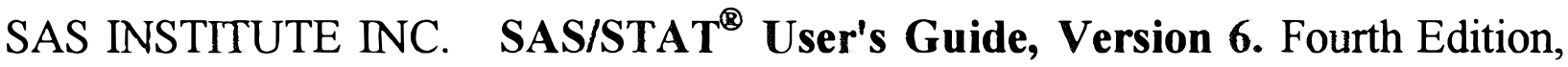
Vol.2, Cary, NC:SAS Institute Inc., 1989. 846 pp.

SCHAPAUGH JUNIOR., W.T. \& WILCOX, J.R. Relationships between harvest indices and other plant characteristics in soybeans. Crop Science, Madison, 20: 529-33, 1980.

SCOTT, A.J. \& KNOTT, M. A cluster analysis method for grouping means in the analysis of variance. Biometrics, Washington, 30: 507-12, 1974.

SMITH, J.D. \& KINMAM, M.L. The use of parent-offspring regression as an estimator of heritability. Crop Science, Madison, 5: 595-6, 1965.

SILVELA, L. \& DIEZ-BARRA, R. Recurrent selection in autogamous species under forced randim mating. Euphytica, Wageningen, 34: 817-32, 1985. 
SOLDINI, D.O. Interação genótipos $\mathrm{x}$ locais e correlações entre caracteres com ênfase na produtividade de óleo em soja. Piracicaba, 1993. 136 p. (MestradoEscola Superior de Agricultura "Luiz de Queiroz"/(USP).

SOUSA, E.L.L. de O Agribusiness da Soja. In: Curso de Comercialização de Commodities Agropecuárias, 6. Piracicaba, S.P., FEALQ, 1995. p. 83-96.

SOUZA JÚNIOR, C.L. Aplicações da covariância entre parentes no melhoramento. In: Componentes da variância genética e suas implicações no melhoramento vegetal. Piracicaba, FEALQ, 1989. cap.8, p.79-130.

SOUZA, E.A.; RAMALHO, A.P. Estimates of genetic and phenotypic variance of same traits of dry bean using a segregant population from the cross "Jalo $\mathrm{x}$ Small White". Revista Brasileira de Genética, Ribeirão Preto, 18 (1): 8991, 1985.

SPEHAR, C.R. Breeding soybeans to the low latitudes of Brazilian cerrados (savannahs). Pesquisa Agropecuária Brasileira, Brasília, 29(8): 1167-80, 1994.

SPEHAR, C.R.; MONTEIRO, P.M.F.O.; ZUFFO, N.L. Melhoramento genético das soja na região Centro-Oeste. In: ARANTES, N.E. \& SOUZA, P.I.M., ed. Cultura da soja nos cerrados. Piracicaba, POTAFOS, 1993. p. 229-53.

SPECHT, J.E. \& GRAEF, G.L. Breeding methodologies for Chickpea: New avenues to greater productivity. In: INTERNATIONAL WORKSHOP ON CHICKPEA IMPROVEMENT, 2. Proceedings, India, ICRISAT, 1990, p. 217-23.

SPECHT, J.E. \& WILLIAMS, J.H. Contribution of genetic technology to soybean productivity - retrospect and prospect. In: FEHR, W.R., ed. Genetic contributions to yield gains in five major crop plants. Madison, Crop Science Society of America, 1984. p.49-74.

ST. MARTIN, S.K. \& EHOUNOU, N.E. Randomness of intermating in soybean populations containing male-sterile plants. Crop Science, Madison, 29: 69$71,1989$. 
STEEL, R.G.D. \& TORRIE, J.H. Principles and procedures of statistics. 2.ed. New York, McGraw-Hill, 1980. 633 p.

SUMARNO \& FEHR, W.R. Response to recurrent selection for yield in soybeans. Crop Science, Madison, 22: 295-9, 1982.

TEDFORD, E.C. \& NIELSEN, M.T. Recurrent selection for black shank resistance in a synthetic tobacco population. Tobacco Science, New York, 34: 70-3, 1990.

TINIUS, C.N.; BURTON, J.W.; CARTER JUNIOR., T.E. Recurrent selection for seed size in soybean: II. Indirect Effects on seed growth rate. Crop Science, Madison, 32: 1480-3, 1992.

TOLEDO, J.F.F. Quantitative genetics in soybean breeding. In: WORLD SOYBEAN RESEARCH CONFERENCE, 4., 1989. Proceedings. Buenos Aires. AASOJA, 1989. v.2, p. 904-14.

TOLEDO, J.F.F.; ALMEIDA, L.A.; KUHL, R.A.; MENOSSO, O.G. Ganho genético em soja no Estado do Paraná, via melhoramento. Pesquisa Agropecuária Brasileira, Brasília, 25(1): 89-94, 1990.

TOLEDO, J.F.F.; OLIVEIRA, M.F.; TSUTIDA, A.C.; KIIHL, R.A.S. Genetic analysis of growth of determinate soybean genotypes under three photoperiods. Revista Brasileira de Genética, Ribeirão Preto, 16(3): 713-48, 1993.

TOLEDO, J.F.F.; TRILLER, C.; DONATO, L.T. OLIVEIRA, M.F.; TSUTIDA, A.C. Genetic control of flowering in determinate soybean genotypes under diverse photoperiods. Revista Brasileira de Genética, Ribeirão Preto, 17(2): 187-95, 1994.

VELLO, N.A. Ampliação da base genética do germoplasma e melhoramento da soja na ESALQ/USP. In: CÂMARA, G.M.S.; MARCOS FILHO, J.; OLIVEIRA, E.A.M., ed. Simpósio sobre a cultura e produtividade da soja. Piracicaba, FEALQ, 1992, p. 60-81.

VÉLLO, N.A. Base genética, fontes de genes e métodos de melhoramento para resistência a doenças. In: BANDEL, G.; VELLO, N.A.; MIRANDA FILHO, J.B., ed. Encontro sobre Temas de Genética e Melhoramento, 12. Piracicaba, ESALQ, 1995, p.11-23. 
VELLO, N.A.; FEHR, W.R.; BAHRENFUS, J.B. Genetic variability and agronomic performance of soybean populations developed from plant introductions. Crop Science, Madison, 24: 511-4, 1984.

VELLO, N.A.; HIROMOTO, D.M.; AZEVEDO FILHO, J.B.V. Coefficient of parentage and breeding of Brazilian soybean germplasm. Revista Brasileira de Genética, Ribeirão Preto, 11(3): 679-97, 1988.

VELLO, N.A. \& PIRES, C.E.L.S. Estratégias para a seleção de parentais. Revista Brasileira de Genética, Ribeirão Preto, 15(1): 45-9, 1992.

VENCOVSKY, R. Herança quantitativa. In: PATERNIANI, E. \& VIEGAS, G.P., ed. Melhoramento e produção de milho. 2a. ed. Campinas, Fundação Cargill, 1987. v. 1., p. 135-214.

VENCOVSKY, R. \& BARRIGA, P. Componentes da variação fenotípica: análise em um ambiente. In: Genética biométrica no fitomelhoramento. Ribeirão Preto, Sociedade Brasileira de Genética, 1992a. cap.3, p.83-227.

VENCOVSKY, R. \& BARRIGA, P. Associação entre caracteres. In: Genética biométrica no fitomelhoramento. Ribeirão Preto, Sociedade Brasileira de Genética, 1992b. cap.5, p.335-434.

VOIGT, R.L. \& WEBER, C.R. Effectiveness of selection methods for yield in soybean crosses. Agronomy Journal, Madison, 52: 527-30, 1960.

ZHIHONG, H. \& JUNZHENG, Z. Study on soybean recurrent selection applied to male-sterelity. Soybean Genetics Newsletter, Ames, 18: 86-9, 1991.

WALKER, A.K. \& SCHMITTHENNER, A.F. Recurrent selection for tolerance to Phytophthora rot in soybean. Crop Science, Madison, 24: 495-7, 1984.

WEISS, M.G.; WEBER, C.R.; KALTON, R.R. Early generation testing in soybeans. Journal of the American Society of Agronomy, Washington, 39: 791-811, 1947.

WEBER, C.R. \& MOORTHY, B.R. Hereditable and nonhereditable relationships and variability of oil content and agronomic characters in the F2 generation of soybean crosses. Agronomy Journal, Madison, 44: 202-9, 1952. 
WEBER, W.E.; QUALSET, C.O.; WRICKE, G. Selection strategies for the improvement of autogamous species. In: BROWN, A.H.D.; CLEEG, M.T.; KAHLER, A.L. WEIR, B.S., ed. Plant Population Genetics, Breeding and Genetic Resources. Sunderland: Sinauer Associates, 1990. cap. 17, p. 229316.

WERNER, B.K. \& WILCOX, J.R. Recurrent selection for yield in Glycine max using genetic male-sterility. Euphytica, Wageningen, 50: 19-26, 1990.

WILCOX, J.R. \& MAY, M.L. Evaluation of $\mathrm{S}_{0}$ progenies from pollinations of male-sterile soybeans. Eurosoya, 4: 5-9, 1986.

WILCOX, J.R. \& SCHAPAUGH JUNIOR., W.T. Effectiveness of single plant selection during successive generations of inbreeding in soybeans. Crop Science, Madison, 20: 809-11, 1980.

YORINORI, J.T.; CHARCHAR, M.J.d'A.; NASSER, L.C.B. \& HENNING, A.A. Doenças da soja e seu controle. In: ARANTES, N.E. \& SOUZA, P.I.M., ed. Cultura da soja nos cerrados. Piracicaba, POTAFOS. 1993. p. 334-97. 
TABELAS 
Tabela 1 Análise de variância (ANAVA) em blocos ao acaso, apresentando as esperanças matemáticas dos quadrados módios.

\begin{tabular}{|c|c|c|c|}
\hline F. VARIAÇÃO & G.L. & Q.M. & $\mathrm{E}(\mathrm{Q} \cdot \mathrm{M})$ \\
\hline Repetições (R) & $r-1$ & Q.M.1 & $-\cdots$ \\
\hline Genótipos (G) & $g-1$ & Q.M.2 & $(1 / N) \sigma_{d}^{2}+\sigma_{e}^{2}+r \sigma_{g}^{2}$ \\
\hline Testemunhas $(\mathrm{T})$ & $t-1$ & Q.M.3 & $(1 / N) \sigma_{d}^{2}+\sigma_{e}^{2}+r \sigma_{t}^{2}$ \\
\hline Populações (P) & $\mathrm{p}-1$ & Q.M.4 & $(1 / N) \sigma_{d}^{2}+\sigma_{e}^{2}+r \sigma_{p}^{2}$ \\
\hline Testem. vs. Popul. & 1 & Q.M.5 & - \\
\hline Resíduo & $(\mathrm{r}-1)(\mathrm{g}-1)$ & Q.M.6 & $(1 / N) \sigma_{d}^{2}+\sigma_{e}^{2}$ \\
\hline TOTAL & (r.g) -1 & $-\ldots$ & $\cdots$ \\
\hline
\end{tabular}

$\mathrm{N}$ : Número médio de plantas da parcela

$\sigma_{d}^{2}:$ Variância dentro das parcelas

$\sigma_{\mathrm{e}}^{2}$ : Variância ambiental entre parcelas

Tabela 2 Análise de covariancia (ANCOVA) em blocos ao acaso, apresentando as esperanças matemáticas dos produtos médios, para o par de caracteres $(\mathrm{X}, \mathrm{Y})$.

\begin{tabular}{lllll}
\hline F. VARIAÇÃO & G.L. & Q.M. & P.M.(X,Y) & E(P.M.) \\
\cline { 2 - 4 } & & X Y Y & \\
\hline
\end{tabular}

\begin{tabular}{|c|c|c|c|c|c|}
\hline Repetições (R) & $\mathrm{R}-1$ & $\cdots$ & $\cdots$ & -- & $\cdots$ \\
\hline Genótipos (G) & $\mathrm{G}-1$ & - & -- & - & $-\cdots$ \\
\hline Testemunhas $(\mathrm{T})$ & $T-1$ & $V_{F(x)}$ & $\mathrm{V}_{\mathrm{F}(\mathrm{v})}$ & $\operatorname{COV}_{\mathrm{f}(\mathrm{x}, \mathrm{v})}$ & $(1 / N) C O V_{d(x, y)}+\operatorname{COV}_{e(x, y)}+r C V_{g(x, y)}$ \\
\hline Populações (P) & P - 1 & $V_{F(x)}$ & $\mathrm{V}_{\mathrm{F}(\mathrm{y})}$ & $\operatorname{COV}_{\mathrm{f}(\mathrm{x}, \mathrm{y})}$ & $(1 / N) \operatorname{COV}_{d(x, y)}+\operatorname{COV}_{e(x, y)}+r \operatorname{COV}_{g(x, y)}$ \\
\hline Resíduo & $(\mathrm{R}-1)(\mathrm{T}-1)$ & $V_{E(x)}$ & $V_{E(v)}$ & $\operatorname{COV}_{\mathrm{e}(\mathrm{x}, \mathrm{y})}$ & $(1 / N) \operatorname{COV}_{d(x, y)}+\operatorname{COV}_{e(x, y)}$ \\
\hline
\end{tabular}

Tabela 3 Análise de variância conjunta de ambientes (ANAVA) em blocos ao acaso, apresentando as esperanças matemáticas dos quadrados médios.

\begin{tabular}{|c|c|c|c|}
\hline F. VARIAÇĀO & G.L. & Q.M. & E(Q.M.) \\
\hline Rep/Amb.(R/A) & $(r-1) \cdot a$ & Q.M.1 & - \\
\hline Genótipos (G) & $\mathrm{g}-1$ & Q.M.2 & $(1 / N) \sigma_{d}^{2}+\sigma_{e}^{2}+$ r.a $\sigma_{g}^{2}$ \\
\hline Ambientes (A) & $a-1$ & Q.M.3 & $(1 / N) \sigma_{d}^{2}+\sigma_{e}^{2}+g \sigma_{b}^{2}+$ r.a/a-1 $\sigma_{g a}^{2}+$ r.g. $\sigma_{a}^{2}$ \\
\hline$G \times A$ & $(a-1)(g-1)$ & Q.M.4 & $(1 / N) \sigma_{d}^{2}+\sigma_{e}^{2}+r \cdot a / a-1 \cdot \sigma_{g a}^{2}$ \\
\hline Resíduo médio & a. $(r-1)(g-1)$ & Q.M.5 & $(1 / N) \sigma_{d}^{2}+\sigma_{e}^{2}$ \\
\hline TOTAL & (r.g.a) -1 & - & $\cdots$ \\
\hline
\end{tabular}

$\mathrm{N}=$ Número de plantas da parcela

$\sigma_{d}^{2}$ : Variância dentro das parcelas

$\sigma_{\mathrm{e}}^{2}$ : Variância ambiental entre parcelas

Ambientes foram considerados efeitos fixos e Genótipos aleatórios. 
Tabela 4 NDF: Número de dias para o florescimento de 20 parentais. Número de plantas (N), média $\left(\bar{Y}_{i}\right)$, porcentagem em relação à média geral (\%), valores minimos (Min.) e máximos (Max.), amplitude $\left(\right.$ Ampl. $=$ Max. - Min.) e variância fenotípica entre plantas $\left(\mathrm{S}_{\mathrm{d}}^{2}\right)$. Soja, Piracicaba - SP ( semeadura 04/12/1992) e Maracai - SP (semeadura 02/12/1993).

\begin{tabular}{|c|c|c|c|c|c|c|c|}
\hline GENOTIPO & $\mathrm{N}$ & $\overline{\bar{Y}}_{i}^{a}$ & $(\%)$ & Min. & Max. & Ampl. & $\mathrm{S}_{\mathrm{d}}^{2 b}$ \\
\hline & & & Piracicaba & $1992 / 93$ & & & \\
\hline Cristalina & 9 & 67 & 99 & 64 & 71 & 7 & 6,39 \\
\hline EMGOPA-301 & 10 & 73 & 107 & 68 & 75 & 7 & 4,93 \\
\hline IAC-4 & 10 & 60 & 88 & 54 & 64 & 10 & 6,79 \\
\hline IAC-5 & 11 & 58 & 85 & 57 & 60 & 3 & 1,23 \\
\hline IAC-6 & 5 & 73 & 107 & 71 & 78 & 7 & 11,20 \\
\hline IAC-8 & 9 & 63 & 93 & 60 & 69 & 9 & 9,04 \\
\hline IAC-9 & 11 & 70 & 103 & 60 & 74 & 14 & 11,82 \\
\hline IAC-11 & 9 & 63 & 93 & 61 & 64 & 3 & 0,00 \\
\hline Santa Rosa & 11 & 59 & 87 & 57 & 66 & 9 & 12,96 \\
\hline SS-1 & 10 & 60 & 88 & 57 & 66 & 9 & 3,60 \\
\hline BR-11 & 7 & 80 & 118 & 77 & 81 & 4 & 2,86 \\
\hline BR79-63 & 9 & 75 & 110 & 66 & 78 & 12 & 11,15 \\
\hline G079-1039 & 10 & 78 & 115 & 77 & 89 & 12 & 14,40 \\
\hline Tropical & 6 & 78 & 115 & 77 & 80 & 3 & 0,22 \\
\hline Numbaíra & 11 & 68 & 100 & 64 & 69 & 5 & 3,72 \\
\hline Paranagoiana & 9 & 68 & 100 & 66 & 69 & 3 & 1,50 \\
\hline Timbira & 7 & 82 & 121 & 81 & 86 & 5 & 0,29 \\
\hline IAC-2 & 10 & 56 & 82 & 54 & 57 & 3 & 0,00 \\
\hline IAC80-3006 & 9 & 64 & 94 & 64 & 66 & 2 & 0,44 \\
\hline White Biloxi & 4 & 65 & 96 & 64 & 66 & 2 & 1,00 \\
\hline \multirow[t]{2}{*}{ MÉDIA GERAL } & 9 & 68 & 100 & - & - & - & 5,18 \\
\hline & & & Maracaí & $1993 / 94$ & & & \\
\hline Cristalina & 12 & 66 & 97 & 64 & 68 & 4 & 1,47 \\
\hline EMGOPA-301 & 10 & 73 & 108 & 70 & 75 & 5 & 2,05 \\
\hline IAC-4 & 11 & 64 & 95 & 63 & 65 & 2 & 0,18 \\
\hline IAC-5 & 10 & 58 & 87 & 58 & 61 & 3 & 0,90 \\
\hline IAC-6 & 10 & 72 & 107 & 70 & 75 & 5 & 2,98 \\
\hline IAC-8 & 9 & 60 & 89 & 59 & 60 & 1 & 0,11 \\
\hline IAC-9 & 11 & 68 & 102 & 67 & 69 & 2 & 0,18 \\
\hline IAC-11 & 7 & 64 & 95 & 63 & 67 & 4 & 1,86 \\
\hline Santa Rosa & 11 & 63 & 93 & 61 & 64 & 3 & 0,26 \\
\hline SS-1 & 12 & 56 & 83 & 56 & 56 & 0 & 0,00 \\
\hline BR-11 & 7 & 80 & 119 & 75 & 81 & 6 & 4,43 \\
\hline BR79-63 & 12 & 75 & 111 & 74 & 75 & 1 & 0,22 \\
\hline G079-1039 & 11 & 74 & 111 & 74 & 75 & 1 & 0,30 \\
\hline Tropical & 10 & 75 & 111 & 73 & 75 & 2 & 0,40 \\
\hline Numbaíra & 8 & 67 & 100 & 64 & 68 & 4 & 0,88 \\
\hline Paranagoiana & 11 & 66 & 98 & 64 & 69 & 5 & 1,36 \\
\hline Timbira & 10 & 79 & 118 & 78 & 82 & 4 & 2,88 \\
\hline IAC-2 & 7 & 58 & 86 & 56 & 59 & 3 & 1,71 \\
\hline IAC80-3006 & 12 & 65 & 97 & 64 & 66 & 2 & 0,62 \\
\hline White Biloxi & 10 & 64 & 95 & 64 & 65 & 1 & 0,23 \\
\hline MÉDIA GERAL & 10 & 67 & 100 & - & - & - & 1,15 \\
\hline
\end{tabular}

${ }^{3}$ Média aritmética de todos os valores individuais $(i=1,2, \ldots, N)$.

${ }^{b}$ Variância ponderada, conforme a frequência de plantas $(n=1,2, \ldots, 6)$ e respectiva variância por repetição, com as duas repetições. 
Tabela 5 APF: Altura da planta no florescimento $(\mathrm{cm})$ de 20 parentais. Número de plantas $(\mathrm{N})$, média $\left(\bar{Y}_{i}\right)$, porcentagem em relação à média geral $(\%)$, valores mínimos (Min.) e máximos (Max.), amplitude $($ Ampl $=$ Max. - Min. $)$ e variância fenotípica entre plantas $\left(\mathbf{S}_{d}{ }_{d}\right)$. Soja , Piracicaba - SP (sem. 04/12/1992) e Maracaí - SP (sem. 02/12/1993).

\begin{tabular}{|c|c|c|c|c|c|c|c|}
\hline GENOTPO & $\mathbf{N}$ & $\overline{\bar{Y}_{i}^{\mathrm{a}}}$ & $(\%)$ & Min. & Max. & Ampl. & $\mathrm{S}_{\mathrm{d}}^{2 b}$ \\
\hline & & & Piracicaba & $1992 / 93$ & & & \\
\hline Cristalina & 9 & 58,89 & 90 & 49 & 72 & 23 & 69,96 \\
\hline EMGOPA-301 & 10 & 79,10 & 121 & 58 & 94 & 36 & 68,26 \\
\hline IAC- 4 & 10 & 50,40 & 77 & 37 & 61 & 24 & 41,35 \\
\hline IAC-5 & 11 & 59,09 & 90 & 43 & 68 & 25 & 41,21 \\
\hline IAC- 6 & 5 & 78,40 & 119 & 75 & 85 & 10 & 26,20 \\
\hline IAC-8 & 9 & 61,44 & 94 & 40 & 79 & 39 & 222,87 \\
\hline IAC-9 & 11 & 72,82 & 111 & 57 & 85 & 28 & 98,04 \\
\hline IAC-11 & 9 & 59,33 & 90 & 50 & 67 & 17 & 20,67 \\
\hline Santa Rosa & 11 & 54,27 & 83 & 46 & 65 & 19 & 33,18 \\
\hline SS-1 & 10 & 47,80 & 73 & 36 & 61 & 25 & 57,25 \\
\hline BR-11 & 7 & 73,14 & 111 & 62 & 91 & 29 & 117,38 \\
\hline BR79-63 & 9 & 76,33 & 116 & 64 & 97 & 33 & 84,69 \\
\hline G079-1039 & 10 & 81,70 & 124 & 48 & 94 & 46 & 171,90 \\
\hline Tropical & 6 & 88,50 & 135 & 77 & 95 & 18 & 23,50 \\
\hline Numbaíra & 11 & 64,64 & 98 & 58 & 76 & 18 & 20,64 \\
\hline Paranagoiana & 9 & 60,44 & 92 & 48 & 75 & 27 & 46,57 \\
\hline Timbira & 7 & 71,57 & 109 & 50 & 86 & 36 & 11,21 \\
\hline IAC-2 & 10 & 60,00 & 91 & 48 & 70 & 22 & 62,20 \\
\hline IAC80-3006 & 9 & 56,78 & 87 & 49 & 63 & 14 & 19,57 \\
\hline White Biloxi & 4 & 58,25 & 89 & 50 & 71 & 21 & 65,25 \\
\hline \multirow[t]{2}{*}{ MÉDIA GERAL } & 9 & 65,64 & 100 & - & - & - & 65,1 \\
\hline & & & Maracai & 1993/94 & & & \\
\hline Cristalina & 12 & 55,42 & 87 & 45 & 64 & 19 & 22,42 \\
\hline EMGOPA-301 & 10 & 69,10 & 109 & 40 & 82 & 42 & 124,00 \\
\hline IAC-4 & 11 & 55,45 & 87 & 49 & 66 & 17 & 25,97 \\
\hline IAC-5 & 10 & 52,70 & 83 & 44 & 61 & 17 & 21,65 \\
\hline IAC- 6 & 10 & 64,90 & 102 & 55 & 72 & 17 & 26,02 \\
\hline IAC-8 & 9 & 70,67 & 111 & 46 & 96 & 50 & 191,96 \\
\hline IAC-9 & 11 & 62,91 & 99 & 50 & 75 & 25 & 42,83 \\
\hline IAC-11 & 7 & 60,00 & 94 & 55 & 64 & 9 & 1,19 \\
\hline Santa Rosa & 10 & 51,60 & 81 & 48 & 60 & 12 & 10,87 \\
\hline SS-1 & 12 & 52,58 & 83 & 48 & 59 & 11 & 12,88 \\
\hline BR-11 & 7 & 78,71 & 124 & 66 & 88 & 22 & 97,14 \\
\hline BR79-63 & 12 & 75,33 & 119 & 60 & 86 & 26 & 59,63 \\
\hline G079-1039 & 11 & 82,82 & 130 & 72 & 91 & 19 & 13,05 \\
\hline Tropical & 10 & 75,50 & 119 & 44 & 95 & 51 & 149,70 \\
\hline Numbaíra & 8 & 66,25 & 104 & 63 & 72 & 9 & 14,94 \\
\hline Paranagoiana & 11 & 55,27 & 87 & 43 & 62 & 19 & 38,26 \\
\hline Timbira & 10 & 75,90 & 120 & 63 & 87 & 24 & 51,14 \\
\hline IAC-2 & 7 & 49,00 & 77 & 45 & 56 & 11 & 13,67 \\
\hline IAC80-3006 & 12 & 52,08 & 82 & 46 & 58 & 12 & 11,48 \\
\hline White Biloxi & 10 & 64,00 & 101 & 43 & 78 & 35 & 122,17 \\
\hline MÉDIA GERAL & 10 & 63,51 & 100 & - & - & - & 52,55 \\
\hline
\end{tabular}

${ }^{2}$ Média aritmética de todos os valores individuais $(i=1,2, \ldots, N)$.

${ }^{b}$ Variância ponderada, conforme a freqüência de plantas $(n=1,2, \ldots, 6)$ e respectiva variância por repetição, com as duas repetições. 
Tabela 6 NDM: Número de dias para a maturidade de 20 parentais. Número de plantas (N), média $\left(\overline{\mathrm{Y}}_{\mathrm{i}}\right)$, porcentagem em relação à média geral $(\%)$, valores mínimos (Min.) e máximos (Max.), amplitude $\left(\mathrm{Ampl}=\mathrm{Max}\right.$ - Min.) e variância fenotípica entre plantas $\left(\mathrm{S}_{\mathrm{d}}^{2}\right)$. Soja , Piracicaba - SP ( semeadura 04/12/1992) e Maracaí - SP (semeadura 02/12/1993).

\begin{tabular}{|c|c|c|c|c|c|c|c|}
\hline GENOTIPO & $\mathrm{N}$ & $\overline{\bar{Y}_{i}^{a}}$ & $(\%)$ & Min. & Max. & Ampl. & $\mathrm{S}_{\mathrm{d}}^{2 \mathrm{~b}}$ \\
\hline & & & Piracicaba & $1992 / 93$ & & & \\
\hline Cristalina & 9 & 155 & 106 & 144 & 161 & 17 & 47,30 \\
\hline EMGOPA-301 & 10 & 156 & 107 & 144 & 161 & 17 & 41,30 \\
\hline IAC-4 & 10 & 135 & 92 & 131 & 139 & 8 & 16,64 \\
\hline IAC-5 & 10 & 132 & 90 & 131 & 139 & 8 & 6,40 \\
\hline IAC- 6 & 5 & 154 & 105 & 151 & 161 & 10 & 23,20 \\
\hline IAC-8 & 8 & 141 & 97 & 131 & 151 & 20 & 20,17 \\
\hline IAC-9 & 11 & 147 & 101 & 131 & 151 & 20 & 52,45 \\
\hline IAC-11 & 9 & 135 & 92 & 131 & 139 & 8 & 13,44 \\
\hline Santa Rosa & 10 & 139 & 95 & 131 & 151 & 20 & 29,44 \\
\hline SS-1 & 10 & 131 & 90 & 131 & 131 & 0 & 0,00 \\
\hline BR-11 & 7 & 161 & 110 & 144 & 178 & 34 & 73,90 \\
\hline BR79-63 & 9 & 157 & 108 & 139 & 161 & 22 & 65,11 \\
\hline G079-1039 & 9 & 159 & 109 & 151 & 161 & 10 & 16,67 \\
\hline Tropical & 6 & 153 & 105 & 151 & 161 & 10 & 16,67 \\
\hline Numbaíra & 11 & 143 & 98 & 139 & 144 & 5 & 5,91 \\
\hline Paranagoiana & 9 & 149 & 102 & 144 & 151 & 7 & 8,17 \\
\hline Timbira & 7 & 156 & 107 & 151 & 168 & 17 & 0,00 \\
\hline IAC-2 & 10 & 133 & 91 & 131 & 139 & 8 & 14,93 \\
\hline IAC80-3006 & 9 & 135 & 92 & 131 & 139 & 8 & 20,15 \\
\hline White Biloxi & 4 & 140 & 96 & 131 & 149 & 18 & 41,00 \\
\hline \multirow[t]{2}{*}{ MÉDIA GERAL } & 9 & 145 & 100 & - & - & - & 25,64 \\
\hline & & & Maracaí & 1993/94 & & & \\
\hline Cristalina & 12 & 137 & 101 & 134 & 139 & 5 & 0,00 \\
\hline EMGOPA-301 & 10 & 140 & 104 & 139 & 142 & 3 & 0,60 \\
\hline IAC-4 & 11 & 127 & 94 & 126 & 129 & 3 & 0,00 \\
\hline IAC-5 & 10 & 129 & 96 & 129 & 133 & 4 & 1,60 \\
\hline IAC- 6 & 9 & 138 & 102 & 137 & 139 & 2 & 0,44 \\
\hline IAC-8 & 9 & 128 & 95 & 126 & 135 & 9 & 4,00 \\
\hline IAC-9 & 11 & 140 & 104 & 139 & 144 & 5 & 1,45 \\
\hline IAC-11 & 7 & 126 & 93 & 123 & 129 & 6 & 5,29 \\
\hline Santa Rosa & 11 & 133 & 98 & 123 & 139 & 16 & 1,23 \\
\hline SS-1 & 12 & 117 & 87 & 117 & 119 & 2 & 0,33 \\
\hline BR-11 & 4 & 144 & 107 & 140 & 146 & 6 & 6,50 \\
\hline BR79-63 & 12 & 151 & 112 & 145 & 154 & 9 & 3,75 \\
\hline G079-1039 & 11 & 154 & 114 & 154 & 154 & 0 & 0,00 \\
\hline Tropical & 10 & 149 & 111 & 144 & 154 & 10 & 0,15 \\
\hline Numbaíra & 8 & 135 & 100 & 129 & 139 & 10 & 0,00 \\
\hline Paranagoiana & 11 & 128 & 95 & 127 & 129 & 2 & 0,00 \\
\hline Timbira & 10 & 142 & 105 & 139 & 145 & 6 & 1,62 \\
\hline IAC-2 & 7 & 139 & 103 & 139 & 139 & 0 & 0,00 \\
\hline IAC80-3006 & 12 & 124 & 92 & 123 & 126 & 3 & 0,75 \\
\hline White Biloxi & 10 & 127 & 94 & 123 & 129 & 6 & 4,80 \\
\hline MEEDIA GERAL & 10 & 135 & 100 & - & - & - & 1,63 \\
\hline
\end{tabular}

${ }^{2}$ Média aritmética de todos os valores individuais $(\mathrm{i}=1,2, \ldots, \mathrm{N})$.

${ }^{b}$ Variância ponderada, conforme a freqüência de plantas $(n=1,2, \ldots, 6)$ e respectiva variância por repetição, com as duas repetições. 
Tabela 7 APM: Altura da Planta na Maturidade de 20 parentais $(\mathrm{cm})$. Número de Plantas $(\mathrm{N})$, média $\left(\bar{Y}_{i}\right)$, porcentagem em relação à média geral (\%), valores mínimos (Min.) e máximos (Max.), amplitude $($ Ampl $=$ Max. - Min. $)$ e variância fenotípica entre plantas $\left(S_{d}^{2}\right)$. Soja, Piracicaba SP (semeadura 04/12/1992) e Maracai - SP (semeadura 02/12/1993).

\begin{tabular}{|c|c|c|c|c|c|c|c|}
\hline GENOTIPO & $\bar{N}$ & $\overline{\bar{Y}_{i}^{2}}$ & $(\%)$ & Min & Max. & Ampl. & $\mathrm{S}_{\mathrm{d}}^{2 \mathrm{~b}}$ \\
\hline & & & Piracicaba & $1992 / 93$ & & & \\
\hline Cristalina & 9 & 75,89 & 88 & 57 & 95 & 38 & 101,19 \\
\hline EMGOPA-301 & 10 & 102,80 & 120 & 85 & 125 & 40 & 124,07 \\
\hline IAC-4 & 10 & 68,70 & 80 & 55 & 75 & 20 & 29,30 \\
\hline IAC-5 & 10 & 89,00 & 104 & 75 & 110 & 35 & 36,00 \\
\hline IAC-6 & 5 & 90,80 & 106 & 87 & 95 & 8 & 19,40 \\
\hline IAC-8 & 8 & 75,00 & 87 & 62 & 85 & 23 & 85,92 \\
\hline IAC-9 & 11 & 83,64 & 97 & 65 & 96 & 31 & 65,50 \\
\hline IAC-11 & 9 & 86,67 & 101 & 80 & 95 & 15 & 47,22 \\
\hline Santa Rosa & 10 & 69,80 & 81 & 55 & 85 & 30 & 83,59 \\
\hline SS-1 & 10 & 75,00 & 87 & 55 & 85 & 30 & 67,50 \\
\hline BR-11 & 7 & 90,71 & 106 & 80 & 120 & 40 & 179,38 \\
\hline BR79-63 & 9 & 90,78 & 106 & 70 & 110 & 40 & 56,19 \\
\hline GO79-1039 & 9 & 97,33 & 113 & 85 & 105 & 20 & 32,33 \\
\hline Tropical & 6 & 103,67 & 121 & 81 & 120 & 39 & 168,33 \\
\hline Numbaira & 11 & 78,82 & 92 & 70 & 94 & 24 & 34,88 \\
\hline Paranagoiana & 9 & 87,89 & 102 & 75 & 106 & 31 & 82,61 \\
\hline Timbira & 7 & 83,71 & 97 & 50 & 105 & 55 & 36,21 \\
\hline IAC-2 & 10 & 107,00 & 125 & 80 & 120 & 40 & 166,00 \\
\hline IAC80-3006 & 9 & 78,67 & 92 & 70 & 90 & 20 & 53,41 \\
\hline White Biloxi & 4 & 82,50 & 96 & 65 & 95 & 30 & 62,50 \\
\hline \multirow[t]{2}{*}{ MEDIA GERAL } & 9 & 85,92 & 100 & - & - & - & 76,58 \\
\hline & & & Maracaí & $1993 / 94$ & & & \\
\hline Cristalina & 12 & 65,67 & 84 & 55 & 75 & 20 & 34,97 \\
\hline EMGOPA-301 & 10 & 81,80 & 105 & 55 & 97 & 42 & 108,40 \\
\hline LAC-4 & 10 & 63,30 & 81 & 59 & 71 & 12 & 16,25 \\
\hline IAC-5 & 10 & 87,20 & 112 & 79 & 95 & 16 & 32,44 \\
\hline IAC-6 & 9 & 73,33 & 94 & 64 & 80 & 16 & 49,29 \\
\hline IAC-8 & 9 & 75,78 & 97 & 54 & 100 & 46 & 294,18 \\
\hline IAC-9 & 11 & 68,91 & 89 & 61 & 74 & 13 & 25,75 \\
\hline IAC-11 & 7 & 76,00 & 98 & 70 & 81 & 11 & 4,67 \\
\hline Santa Rosa & 11 & 56,36 & 72 & 49 & 61 & 12 & 21,23 \\
\hline SS-1 & 12 & 65,83 & 85 & 59 & 74 & 15 & 18,13 \\
\hline BR-11 & 4 & 87,25 & 112 & 84 & 93 & 9 & 18,25 \\
\hline BR79-63 & 12 & 87,08 & 112 & 73 & 98 & 25 & 50,08 \\
\hline GO79-1039 & 11 & 93,73 & 121 & 83 & 103 & 20 & 13,63 \\
\hline Tropical & 10 & 92,10 & 118 & 80 & 109 & 29 & 64,35 \\
\hline Numbaira & 8 & 72,25 & 93 & 70 & 81 & 11 & 14,63 \\
\hline Paranagoiana & 11 & 70,55 & 91 & 54 & 80 & 26 & 43,19 \\
\hline Timbira & 10 & 83,20 & 107 & 71 & 94 & 23 & 40,72 \\
\hline IAC-2 & 7 & 102,43 & 132 & 94 & 112 & 18 & 34,14 \\
\hline IAC80-3006 & 12 & 63,75 & 82 & 58 & 72 & 14 & 10,02 \\
\hline White Biloxi & 10 & 88,30 & 114 & 68 & 106 & 38 & 180,34 \\
\hline MÉDIA GERAL & 10 & 77,74 & 100 & - & - & - & 53,73 \\
\hline
\end{tabular}

${ }^{2}$ Média aritmética de todos os valores individuais $(\mathrm{i}=1,2, \ldots, \mathrm{N})$.

'Variância ponderada, conforme a frequência de plantas $(n=1,2, \ldots, 6)$ e respectiva variância por repetição, com as duas repetições. 
Tabela 8 VA : Valor Agronômico $(1$ = péssimo a $5=$ excelente) de 20 parentais. Número de plantas $(\mathrm{N})$, média $\left(\bar{Y}_{i}\right)$, porcentagem em relação à média geral (\%), valores mínimos (Min.) e máximos (Max.), amplitude $($ Ampl $=$ Max. - Min. $)$ e variância fenotípica entre plantas $\left(S_{d}^{2}\right)$. Soja, Piracicaba - SP (semeadura 04/12/1992) e Maracaí - SP (semeadura 02/12/1993).

\begin{tabular}{|c|c|c|c|c|c|c|c|}
\hline GENÓTIPO & $\mathrm{N}$ & $\overline{Y_{i}^{a}}$ & $(\%)$ & Min. & Max. & Ampl & $\mathrm{S}_{\mathrm{d}}^{2 \mathrm{~T}}$ \\
\hline & & & Piracicaba & $1992 / 93$ & & & \\
\hline Cristalina & 9 & 4,22 & 93 & 2 & 5 & 3 & 1,06 \\
\hline EMGOPA-301 & 10 & 5,00 & 110 & 5 & 5 & 0 & 0,00 \\
\hline IAC-4 & 10 & 4,00 & 88 & 3 & 5 & 2 & 0,29 \\
\hline IAC-5 & 10 & 4,70 & 104 & 4 & 5 & 1 & 0,26 \\
\hline IAC-6 & 5 & 4,60 & 101 & 4 & 5 & 1 & 0,40 \\
\hline IAC-8 & 8 & 4,50 & 99 & 4 & 5 & 1 & 0,25 \\
\hline IAC-9 & 11 & 4,73 & 104 & 3 & 5 & 2 & 0,45 \\
\hline IAC-11 & 9 & 4,89 & 108 & 4 & 5 & I & 0,11 \\
\hline Santa Rosa & 10 & 4,40 & 97 & 3 & 5 & 2 & 0,44 \\
\hline SS-1 & 10 & 4,40 & 97 & 3 & 5 & 2 & 0,80 \\
\hline BR-11 & 7 & 4,14 & 91 & 3 & 5 & 2 & 0,29 \\
\hline BR79-63 & 9 & 4,56 & 100 & 3 & 5 & 2 & 0,30 \\
\hline G079-1039 & 9 & 4,89 & 108 & 4 & 5 & 1 & 0,11 \\
\hline Tropical & 6 & 4,83 & 106 & 4 & 5 & 1 & 0,17 \\
\hline Numbaíra & 11 & 4,81 & 106 & 4 & 5 & 1 & 0,15 \\
\hline Paranagoiana & 9 & 4,89 & 108 & 4 & 5 & 1 & 0,11 \\
\hline Timbira & 7 & 4,00 & 88 & 3 & 5 & 2 & 0,64 \\
\hline IAC-2 & 10 & 4,30 & 95 & 3 & 5 & 2 & 0,77 \\
\hline IAC80-3006 & 9 & 4,78 & 105 & 3 & 5 & 2 & 0,44 \\
\hline White Biloxi & 4 & 4,25 & 94 & 3 & 5 & 2 & 1,25 \\
\hline \multirow[t]{2}{*}{ MÉDIA GERAL } & 9 & 4,54 & 100 & $=$ & - & - & 0,41 \\
\hline & & & Maracaí & $1993 / 94$ & & & \\
\hline Cristalina & 12 & 4,08 & 96 & 3 & 5 & 2 & 0,28 \\
\hline EMGOPA-301 & 10 & 4,40 & 103 & 3 & 5 & 2 & 0,35 \\
\hline IAC- 4 & 11 & 4,82 & 113 & 4 & 5 & 1 & 0,18 \\
\hline IAC-5 & 10 & 4,20 & 99 & 3 & 5 & 2 & 0,68 \\
\hline IAC- 6 & 9 & 4,22 & 99 & 3 & 5 & 2 & 1,04 \\
\hline IAC-8 & 9 & 3,44 & 81 & 3 & 5 & 2 & 0,89 \\
\hline IAC-9 & 11 & 4,45 & 105 & 4 & 5 & 1 & 0,30 \\
\hline IAC-11 & 7 & 4,57 & 107 & 3 & 5 & 2 & 0,71 \\
\hline Santa Rosa & 11 & 3,64 & 85 & 2 & 5 & 3 & 0,54 \\
\hline SS-1 & 12 & 5,00 & 117 & 5 & 5 & 0 & 0,00 \\
\hline BR-11 & 4 & 4,00 & 94 & 4 & 4 & 0 & 0,00 \\
\hline BR79-63 & 12 & 4,08 & 96 & 3 & 5 & 2 & 0,62 \\
\hline GO79-1039 & 11 & 3,73 & 87 & 3 & 4 & 1 & 0,16 \\
\hline Tropical & 10 & 4,10 & 96 & 3 & 5 & 2 & 0,50 \\
\hline Numbaíra & 8 & 4,38 & 103 & 3 & 5 & 2 & 0,25 \\
\hline Paranagoiana & 11 & 4,36 & 102 & 3 & 5 & 2 & 0,93 \\
\hline Timbira & 10 & 4,40 & 103 & 3 & 5 & 2 & 0,52 \\
\hline IAC-2 & 7 & 4,86 & 114 & 4 & 5 & 1 & 0,14 \\
\hline IAC80-3006 & 12 & 4,50 & 106 & 4 & 5 & 1 & 0,17 \\
\hline White Biloxi & 10 & 3,90 & 92 & 2 & 5 & 3 & 0,77 \\
\hline MEDIA GERAL & 10 & 4,26 & 100 & - & - & - & 0,45 \\
\hline
\end{tabular}

${ }^{3}$ Média aritmética de todos os valores individuais $(\mathrm{i}=1,2, \ldots, \mathrm{N})$.

${ }^{b}$ Variância ponderada, conforme a freqüência de plantas $(n=1,2, \ldots, 6)$ e respectiva variância por repetição, com as duas repetições. 
Tabela 9 PG: Produtividade de Grãos (g/planta) de 20 parentais. Número de plantas $(\mathrm{N})$, média $\left(\overline{\mathrm{Y}}_{\mathrm{i}}\right)$, porcentagem em relação à média geral (\%), valores mínimos (Min.) e máximos (Max.), amplitude (Ampl. = Max. - Min.) e variância fenotipica entre plantas $\left(\mathbf{S}^{2}{ }_{\mathrm{d}}\right)$. Soja, Piracicaba - SP (semeadura 04/12/1992) e Maracai - SP (semeadura 02/12/1993).

\begin{tabular}{|c|c|c|c|c|c|c|c|}
\hline GENOTIPO & $\bar{N}$ & $\overline{\bar{Y}_{i}^{2}}$ & $(\%)$ & Min. & Max. & Ampl. & $\mathrm{S}_{d}^{26}$ \\
\hline & & & Piracicaba & $1992 / 93$ & & & \\
\hline Cristalina & 6 & 155,57 & 139 & 54,27 & 202,20 & 147,93 & 2395,51 \\
\hline EMGOPA-301 & 5 & 139,11 & 124 & 95,85 & 178,28 & 82,43 & 1040,57 \\
\hline IAC-4 & 7 & 87,66 & 78 & 65,81 & 110,72 & 44,91 & 141,25 \\
\hline IAC-5 & 5 & 111,58 & 100 & 85,24 & 157,48 & 72,24 & 1353,83 \\
\hline IAC-6 & 4 & 84,85 & 76 & 44,95 & 130,21 & 85,20 & 3199,30 \\
\hline IAC-8 & 6 & 124,77 & 111 & 93,52 & 158,10 & 64,58 & 913,50 \\
\hline IAC-9 & 9 & 134,66 & 120 & 99,02 & 168,01 & 68,99 & 451,11 \\
\hline IAC-11 & 9 & 127,28 & 114 & 91,06 & 175,78 & 84,72 & 767,47 \\
\hline Santa Rosa & 9 & 105,30 & 94 & 84,33 & 134,43 & 50,10 & 389,30 \\
\hline SS-1 & 7 & 113,14 & 101 & 83,90 & 134,92 & 51,02 & 78,08 \\
\hline BR-11 & 6 & 42,73 & 38 & 19,08 & 96,69 & 77,61 & 459,21 \\
\hline BR79-63 & 5 & 139,70 & 125 & 106,30 & 177,98 & 71,68 & 517,31 \\
\hline G079-1039 & 7 & 131,96 & 118 & 90,90 & 157,97 & 67,07 & 520,75 \\
\hline Tropical & 6 & 129,68 & 116 & 81,86 & 152,65 & 70,79 & 951,70 \\
\hline Numbaira & 10 & 106,94 & 95 & 86,29 & 146,93 & 60,64 & 372,45 \\
\hline Paranagoiana & 5 & 125,81 & 112 & 99,27 & 160,67 & 61,40 & 818,47 \\
\hline Timbira & 7 & 98,71 & 88 & 71,34 & 133,87 & 62,53 & 569,22 \\
\hline IAC-2 & 8 & 82,41 & 74 & 61,78 & 124,56 & 62,78 & 486,23 \\
\hline IAC80-3006 & 5 & 114,79 & 102 & 91,22 & 122,84 & 31,62 & 180,16 \\
\hline White Biloxi & 4 & 83,71 & 75 & 32,40 & 118,02 & 85,62 & 494,13 \\
\hline \multirow[t]{2}{*}{ MÉDIA GERAL } & 7 & 112,02 & 100 & - & - & - & 804,98 \\
\hline & & & Maracaí & $1993 / 94$ & & & \\
\hline Cristalina & 11 & 100,48 & 150 & 64,05 & 143,59 & 79,54 & 255,19 \\
\hline EMGOPA-301 & 7 & 89,84 & 134 & 46,35 & 132,16 & 85,81 & 255,73 \\
\hline IAC-4 & 11 & 81,92 & 122 & 61,04 & 104,61 & 43,57 & 70,48 \\
\hline IAC-5 & 10 & 63,64 & 95 & 42,39 & 96,92 & 54,53 & 395,84 \\
\hline IAC- 6 & 9 & 63,24 & 94 & 40,84 & 90,47 & 49,63 & 353,84 \\
\hline IAC-8 & 7 & 60,92 & 9] & 32,02 & 90,22 & 58,20 & 652,53 \\
\hline IAC-9 & 11 & 81,95 & 122 & 51,63 & 111,27 & 59,64 & 330,40 \\
\hline IAC-11 & 7 & 71,82 & 107 & 45,44 & 99,50 & 54,06 & 112,01 \\
\hline Santa Rosa & 8 & 64,99 & 97 & 43,35 & 82,66 & 39,31 & 267,97 \\
\hline SS-1 & 10 & 87,24 & 130 & 67,69 & 102,44 & 34,75 & 178,57 \\
\hline BR-11 & 4 & 46,62 & 70 & 43,22 & 50,15 & 6,93 & 18,92 \\
\hline BR79-63 & 12 & 56,04 & 84 & 33,48 & 76,61 & 43,13 & 177,66 \\
\hline G079-1039 & 9 & 55,33 & 83 & 39,17 & 71,34 & 32,17 & 132,05 \\
\hline Tropical & 9 & 39,96 & 60 & 29,22 & 61,12 & 31,90 & 100,57 \\
\hline Numbaira & 8 & 55,52 & 83 & 35,73 & 76,95 & 41,22 & 161,46 \\
\hline Paranagoiana & 11 & 66,62 & 99 & 43,02 & 85,64 & 42,62 & 238,38 \\
\hline Timbira & 10 & 56,43 & 84 & 45,18 & 68,65 & 23,47 & 73,17 \\
\hline IAC-2 & 7 & 65,82 & 98 & 41,93 & 99,90 & 57,97 & 236,29 \\
\hline IAC80-3006 & 12 & 58,19 & 87 & 37,22 & 94,96 & 57,74 & 147,36 \\
\hline White Biloxi & 8 & 73,96 & 110 & 40,40 & 107,83 & 67,43 & 359,17 \\
\hline MEDIA GERAL & 9 & 67,03 & 100 & - & - & - & 225,88 \\
\hline
\end{tabular}

${ }^{2}$ Média aritmética de todos os valores individuais $(\mathrm{i}=1,2, \ldots, \mathrm{N})$.

${ }^{b}$ Variância ponderada, conforme a freqüência de plantas $(n=1,2, \ldots, 6)$ e respectiva variância por repetição, com as duas repetições. 
Tabela 10 NDF: Número de Dias para o Florescimento da geração $\mathbf{F}_{2[4]}$ de 45 cruzamentos quádruplos, e de 4 testemunhas. Número de plantas $(\mathrm{N})$, média $\left(\bar{Y}_{\mathrm{i}}\right)$, porcentagem em relação à média $(\%)$, valores minimos (Mín.) e máximos (Max.), amplitude (Max. - Min.), variância fenotípica entre plantas $\left(S_{d}^{2}\right)$, variância genotípica $\left(\mathrm{S}_{\mathrm{g}}^{2}\right)$, herdabilidade no sentido amplo $\left(\mathrm{h}_{\mathrm{a}}^{2}\right)$ e relação entre os coeficientes de variação genética e ambiental (b). Soja, Piracicaba - SP (sem. 04/12/92). VARIÂNCIA AMBIENTAL $\left(\mathbf{S}^{2}{ }_{\mathrm{a}}\right)=11,33$.

\begin{tabular}{|c|c|c|c|c|c|c|c|c|c|c|}
\hline $\begin{array}{c}\text { POPULAÇÃO } \\
F_{2141}\end{array}$ & $\mathrm{~N}$ & $\overline{Y_{i}^{2}}$ & $(\%)$ & Min. & Max. & Ampl. & $\mathrm{S}_{\mathrm{d}}^{2}$ & $\mathrm{~S}_{\mathrm{g}}^{2}$ & $\overrightarrow{\mathrm{h}_{\mathrm{a}}^{2}}$ & b \\
\hline 1 & 34 & 68 & 103 & 54 & 96 & 42 & 195,89 & 184,56 & 0,94 & 4,04 \\
\hline 2 & 42 & 67 & 102 & 54 & 113 & 59 & 105,57 & 94,24 & 0,89 & 2,88 \\
\hline 3 & 37 & 61 & 92 & 54 & 90 & 36 & 69,47 & 58,14 & 0,84 & 2,27 \\
\hline 4 & 37 & 70 & 106 & 54 & 105 & 51 & 105,39 & 94,07 & 0,89 & 2,88 \\
\hline 5 & 42 & 77 & 117 & 54 & 100 & 46 & 221,78 & 210,46 & 0,95 & 4,31 \\
\hline 6 & 41 & 77 & 117 & 54 & 102 & 48 & 119,72 & 108,40 & 0,91 & 3,09 \\
\hline 7 & 35 & 72 & 109 & 54 & 110 & 56 & 215,18 & 203,85 & 0,95 & 4,24 \\
\hline 8 & 39 & 69 & 105 & 54 & 107 & 53 & 162,54 & 151,22 & 0,93 & 3,65 \\
\hline 9 & 25 & 86 & 130 & 57 & 114 & 57 & 248,14 & 236,82 & 0,95 & 4,57 \\
\hline 10 & 42 & 66 & 100 & 54 & 98 & 44 & 111,22 & 99,90 & 0,90 & 2,97 \\
\hline 11 & 46 & 60 & 91 & 54 & 88 & 34 & 58,17 & 46,84 & 0,81 & 2,03 \\
\hline 12 & 39 & 71 & 108 & 54 & 108 & 54 & 208,82 & 197,49 & 0,95 & 4,18 \\
\hline 13 & 41 & 65 & 98 & 54 & 90 & 36 & 129,42 & 118,10 & 0,91 & 3,23 \\
\hline 14 & 24 & 73 & 111 & 57 & 99 & 42 & 87,46 & 76,13 & 0,87 & 2,59 \\
\hline 15 & 41 & 64 & 97 & 54 & 74 & 20 & 28,88 & 17,56 & 0,61 & 1,24 \\
\hline 16 & 38 & 69 & 105 & 54 & 96 & 42 & 161,57 & 150,25 & 0,93 & 3,64 \\
\hline 17 & 28 & 77 & 117 & 57 & 107 & 50 & 229,30 & 217,97 & 0,95 & 4,39 \\
\hline 18 & 42 & 62 & 94 & 54 & 74 & 20 & 32,67 & 21,35 & 0,65 & 1,37 \\
\hline 19 & 39 & 69 & 105 & 57 & 77 & 20 & 16,97 & 5,65 & 0,33 & 0,71 \\
\hline 20 & 44 & 60 & 91 & 54 & 78 & 24 & 30,56 & 19,23 & 0,63 & 1,30 \\
\hline 21 & 38 & 65 & 98 & 54 & 95 & 41 & 94,97 & 83,65 & 0,88 & 2,72 \\
\hline 22 & 42 & 64 & 97 & 54 & 79 & 25 & 55,56 & 44,23 & 0,80 & 1,98 \\
\hline 23 & 42 & 63 & 95 & 54 & 87 & 33 & 52,43 & 41,11 & 0,78 & 1,90 \\
\hline 24 & 44 & 61 & 92 & 54 & 82 & 28 & 55,38 & 44,05 & 0,80 & 1,97 \\
\hline 25 & 37 & 64 & 97 & 54 & 81 & 27 & 75,61 & 64,29 & 0,85 & 2,38 \\
\hline 26 & 45 & 64 & 97 & 54 & 81 & 27 & 43,48 & 32,16 & 0,74 & 1,68 \\
\hline 27 & 41 & 67 & 102 & 54 & 109 & 55 & 82,12 & 70,80 & 0,86 & 2,50 \\
\hline 28 & 44 & 65 & 98 & 54 & 81 & 27 & 57,20 & 45,87 & 0,80 & 2,01 \\
\hline 29 & 41 & 61 & 92 & 54 & 79 & 25 & 60,72 & 49,39 & 0,81 & 2,09 \\
\hline 30 & 43 & 58 & 88 & 51 & 71 & 20 & 27,36 & 16,03 & 0,59 & 1,19 \\
\hline 31 & 39 & 66 & 100 & 54 & 96 & 42 & 40,08 & 28,75 & 0,72 & 1,59 \\
\hline 32 & 43 & 61 & 92 & 51 & 110 & 59 & 146,04 & 134,71 & 0,92 & 3,45 \\
\hline 33 & 41 & 64 & 97 & 54 & 80 & 26 & 52,21 & 40,89 & 0,78 & 1,90 \\
\hline 34 & 44 & 60 & 91 & 54 & 72 & 18 & 22,93 & 11,60 & 0,51 & 1,01 \\
\hline 35 & 45 & 61 & 92 & 54 & 95 & 41 & 64,96 & 53,63 & 0,83 & 2,18 \\
\hline 36 & 44 & 69 & 105 & 54 & 110 & 56 & 226,48 & 215,16 & 0,95 & 4,36 \\
\hline 37 & 42 & 69 & 105 & 54 & 104 & 50 & 175,86 & 164,53 & 0,94 & 3,81 \\
\hline 38 & 40 & 60 & 91 & 51 & 98 & 47 & 122,17 & 110,85 & 0,91 & 3,13 \\
\hline 39 & 41 & 62 & 94 & 54 & 81 & 27 & 57,55 & 46,23 & 0,80 & 2,02 \\
\hline 40 & 42 & 69 & 105 & 54 & 87 & 33 & 58,68 & 47,36 & 0,81 & 2,04 \\
\hline 41 & 42 & 61 & 92 & 54 & 89 & 35 & 72,71 & 61,39 & 0,84 & 2,33 \\
\hline 42 & 43 & 59 & 89 & 54 & 78 & 24 & 45,33 & 34,00 & 0,75 & 1,73 \\
\hline 43 & 39 & 62 & 94 & 54 & 78 & 24 & 53,38 & 42,06 & 0,79 & 1,93 \\
\hline 44 & 44 & 66 & 100 & 54 & 95 & 41 & 123,22 & 111,90 & 0,91 & 3,14 \\
\hline 45 & 43 & 57 & 86 & 54 & 69 & 15 & 17,75 & 6,43 & 0,36 & 0,75 \\
\hline MEDIA $F_{2[4]}$ & - & 66 & 100 & $=$ & $=$ & - & 98,29 & 86,96 & 0,88 & 2,77 \\
\hline Cristalina & 46 & 67 & 104 & 62 & 72 & 10 & 5,18 & - & - & - \\
\hline IAC-8 & 40 & 60 & 94 & 57 & 78 & 21 & 17,77 & - & - & - \\
\hline EMGOPA-301 & 37 & 72 & 113 & 54 & 81 & 27 & 18,88 & - & - & - \\
\hline SS-1 & 41 & 58 & 90 & 54 & 68 & 14 & 9,47 & - & - & - \\
\hline MEDIA TESTEM. & - & 64 & 100 & $=$ & - & - & - & - & - & - \\
\hline
\end{tabular}

Tdentificação dos cruzamentos que deram origem à estas populações $\mathrm{F}_{2[4]}$, no Apêndice 6 . " ${ }^{2}$ Média aritmética de todos os valores individuais $(\mathrm{i}=1,2, \ldots, \mathrm{N})$. ${ }^{\mathrm{b}}$ Variância ponderada , conforme a freqüência de plantas $(n=1,2, \ldots, 12) \mathrm{e}$ respectiva variância por repetição, com as 4 repetições. 
Tabela 11 NDF: Número de Dias para o Florescimento da geração $F_{3: 2[4]}$ de 45 cruzamentos quádruplos, e de 4 testemunhas. Número de covas $(\mathrm{N})$, média $\left(\overline{\mathrm{Y}}_{\mathrm{i}}\right)$, porcentagem em relação à média $(\%)$, valores mínimos (Mín.) e máximos (Max.), amplitude (Max. - Min.), variância fenotipica entre plantas $\left(\mathrm{S}_{\mathrm{d}}{ }_{\mathrm{d}}\right.$ ), variância genotipica $\left(\mathrm{S}_{\mathrm{g}}^{2}\right)$, herdabilidade no sentido amplo $\left(\mathrm{h}_{\mathrm{a}}^{2}\right)$ e relação entre os coeficientes de variação genética e ambiental (b). Soja, Maracai - SP (sem. 02/12/1993). VARIÂNCIA AMBIENTAL $\left(\mathrm{S}^{2}{ }_{\mathrm{a}}\right)=6,93$.

\begin{tabular}{|c|c|c|c|c|c|c|c|c|c|c|}
\hline POPULAÇÃO & $\mathrm{N}$ & $Y_{i}^{a}$ & $(\%)$ & Min. & Max. & Ampl. & $S_{d}^{2 b}-$ & $\mathrm{S}_{\mathrm{g}}^{2-}$ & $\mathrm{h}^{2}-$ & t \\
\hline 1 & 40 & 69 & 104 & 55 & 89 & 34 & 119,81 & 112,88 & 0,94 & 4,04 \\
\hline 2 & 36 & 70 & 105 & 59 & 99 & 40 & 84,12 & 77,19 & 0,92 & 3,34 \\
\hline 3 & 33 & 65 & 98 & 55 & 75 & 20 & 25,42 & 18,50 & 0,73 & 1,63 \\
\hline 4 & 38 & 71 & 106 & 60 & 94 & 34 & 38,33 & 31,40 & 0,82 & 2,13 \\
\hline 5 & 40 & 75 & 114 & 55 & 110 & 55 & 227,39 & 220,47 & 0,97 & 5,64 \\
\hline 6 & 36 & 76 & 114 & 60 & 93 & 33 & 43,25 & 36,33 & 0,84 & 2,29 \\
\hline 7 & 33 & 66 & 100 & 57 & 84 & 27 & 26,66 & 19,73 & 0,74 & 1,69 \\
\hline 8 & 37 & 69 & 104 & 57 & 106 & 49 & 126,65 & 119,72 & 0,95 & 4,16 \\
\hline 9 & 35 & 77 & 116 & 55 & 105 & 50 & 96,80 & 89,87 & 0,93 & 3,60 \\
\hline 10 & 36 & 66 & 100 & 51 & 87 & 36 & 56,42 & 49,50 & 0,88 & 2,67 \\
\hline 11 & 40 & 63 & 95 & 51 & 79 & 28 & 63,18 & 56,25 & 0,89 & 2,85 \\
\hline 12 & 41 & 72 & 108 & 54 & 99 & 45 & 121,05 & 114,12 & 0,94 & 4,06 \\
\hline 13 & 42 & 65 & 98 & 53 & 99 & 46 & 73,88 & 66,95 & 0,91 & 3,11 \\
\hline 14 & 42 & 65 & 99 & 44 & 78 & 34 & 59,17 & 52,24 & 0,88 & 2,75 \\
\hline 15 & 35 & 68 & 103 & 58 & 94 & 36 & 43,13 & 36,20 & 0,84 & 2,29 \\
\hline 16 & 41 & 69 & 104 & 55 & 89 & 34 & 74,35 & 67,43 & 0,91 & 3,12 \\
\hline 17 & 36 & 76 & 114 & 47 & 100 & 53 & 166,70 & 159,77 & 0,96 & 4,80 \\
\hline 18 & 41 & 65 & 98 & 49 & 78 & 29 & 29,72 & 22,79 & 0,77 & 1,81 \\
\hline 19 & 46 & 68 & 102 & 61 & 75 & 14 & 9,23 & 2,31 & 0,25 & 0,58 \\
\hline 20 & 38 & 64 & 97 & 54 & 82 & 28 & 30,49 & 23,56 & 0,77 & 1,84 \\
\hline 21 & 39 & 65 & 99 & 49 & 99 & 50 & 107,34 & 100,41 & 0,94 & 3,81 \\
\hline 22 & 38 & 66 & 99 & 57 & 78 & 21 & 32,19 & 25,26 & 0,78 & 1,91 \\
\hline 23 & 36 & 67 & 101 & 57 & 78 & 21 & 21,51 & 14,58 & 0,68 & 1,45 \\
\hline 24 & 37 & 65 & 98 & 53 & 75 & 22 & 31,70 & 24,77 & 0,78 & 1,89 \\
\hline 25 & 36 & 64 & 97 & 54 & 78 & 24 & 43,51 & 36,58 & 0,84 & 2,30 \\
\hline 26 & 35 & 67 & 101 & 57 & 77 & 20 & 26,96 & 20,03 & 0,74 & 1,70 \\
\hline 27 & 41 & 67 & 101 & 47 & 83 & 36 & 48,21 & 41,28 & 0,86 & 2,44 \\
\hline 28 & 41 & 66 & 99 & 54 & 79 & 25 & 36,83 & 29,90 & 0,81 & 2,08 \\
\hline 29 & 38 & 62 & 94 & 47 & 78 & 31 & 30,18 & 23,25 & 0,77 & 1,83 \\
\hline 30 & 39 & 59 & 90 & 47 & 69 & 22 & 27,62 & 20,69 & 0,75 & 1,73 \\
\hline 31 & 31 & 68 & 103 & 59 & 95 & 36 & 39,37 & 32,44 & 0,82 & 2,16 \\
\hline 32 & 42 & 61 & 92 & 47 & 93 & 46 & 90,73 & 83,80 & 0,92 & 3,48 \\
\hline 33 & 42 & 65 & 97 & 45 & 78 & 33 & 66,97 & 60,04 & 0,90 & 2,94 \\
\hline 34 & 43 & 63 & 95 & 51 & 70 & 19 & 13,19 & 6,26 & 0,47 & 0,95 \\
\hline 35 & 42 & 64 & 96 & 57 & 73 & 16 & 22,35 & 15,42 & 0,69 & 1,49 \\
\hline 36 & 36 & 67 & 101 & 51 & 94 & 43 & 163,32 & 156,39 & 0,96 & 4,75 \\
\hline 37 & 36 & 73 & 11.1 & 47 & 113 & 66 & 286,50 & 279,57 & 0,98 & 6,35 \\
\hline 38 & 43 & 60 & 91 & 45 & 83 & 38 & 63,17 & 56,24 & 0,89 & 2,85 \\
\hline 39 & 33 & 62 & 94 & 51 & 95 & 44 & 73,53 & 66,60 & 0,91 & 3,10 \\
\hline 40 & 44 & 68 & 102 & 44 & 82 & 38 & 33,17 & 26,24 & 0,79 & 1,95 \\
\hline 41 & 42 & 60 & 90 & 47 & 88 & 41 & 84,50 & 77,57 & 0,92 & 3,35 \\
\hline 42 & 42 & 61 & 92 & 44 & 79 & 35 & 49,99 & 43,06 & 0,86 & 2,49 \\
\hline 43 & 43 & 65 & 99 & 56 & 74 & 18 & 28,13 & 21,20 & 0,75 & 1,75 \\
\hline 44 & 39 & 67 & 101 & 45 & 95 & 50 & 83,33 & 76,40 & 0,92 & 3,32 \\
\hline 45 & 45 & 59 & 89 & 51 & 69 & 18 & 20,66 & 13,73 & 0,66 & 1,41 \\
\hline MEDIA $F_{3: 2[4]}$ & $=$ & 66 & 100 & $=$ & - & - & 67,57 & 60,64 & 0,90 & 2,96 \\
\hline Cristalina & 35 & 67 & 104 & 53 & 78 & 25 & 10,54 & - & - & - \\
\hline IAC-8 & 42 & 63 & 97 & 60 & 73 & 13 & 7,00 & - & - & - \\
\hline EMGOPA-301 & 30 & 71 & 111 & 60 & 77 & 17 & 9,96 & - & - & - \\
\hline SS-1 & 42 & 59 & 92 & 54 & 63 & 9 & 3,14 & - & - & - \\
\hline MEDIA TESTEM & - & 65 & 100 & $*$ & - & - & - & - & - & - \\
\hline
\end{tabular}


Tabela 12 APF: Altura da Planta no Florescimento $(\mathrm{cm})$ da geração $F_{2[4]}$ de 45 cruzamentos quádruplos, e de 4 testemunhas. Número de plantas $(\mathrm{N})$, Média $\left(\bar{Y}_{i}\right)$, porcentagem em relação à média $(\%)$, valores mínimos (Mín.) e máximos (Max.), amplitude (Max. - Min.), variância fenotípica entre plantas $\left(\mathrm{S}_{\mathrm{d}}^{2}\right)$, variância genotípica $\left(\mathrm{S}_{\mathrm{g}}^{2}\right)$, herdabilidade no sentido amplo $\left(\mathrm{h}^{2}\right)$ e relação entre os coeficientes de variação genética e ambiental (b). Soja, Piracicaba - SP (sem. 04/12/1992). VARIÂNCIA AMBIENTAL $\left(\mathrm{S}_{\mathbf{a}}^{2}\right)=84,28$.

\begin{tabular}{|c|c|c|c|c|c|c|c|c|c|c|}
\hline $\begin{array}{c}\text { POPULAÇAO } \\
F_{2[4]}\end{array}$ & $\mathrm{N}$ & $\bar{Y}_{i}^{a}$ & $(\%)$ & Min. & Max. & Ampl. & $\mathrm{S}_{\mathrm{d}}^{2}$ & $\mathrm{~S}_{\mathrm{g}}^{2}$ & $\mathrm{~h}_{\mathrm{a}}^{2}$ & $\bar{b}$ \\
\hline 1 & 34 & 68,26 & 102 & 34 & 110 & 76 & 528,01 & 443,73 & 0,84 & 2,29 \\
\hline 2 & 42 & 67,17 & 100 & 44 & 92 & 48 & 152,14 & 67,86 & 0,45 & 0,90 \\
\hline 3 & 37 & 62,57 & 94 & 37 & 102 & 65 & 191,85 & 107,58 & 0,56 & 1,13 \\
\hline 4 & 37 & 69,51 & 104 & 52 & 115 & 63 & 194,68 & 110,41 & 0,57 & 1,14 \\
\hline 5 & 42 & 80,74 & 121 & 37 & 125 & 88 & 489,78 & 405,50 & 0,83 & 2,19 \\
\hline 6 & 41. & 81,85 & 122 & 50 & 110 & 60 & 289,04 & 204,77 & 0,71 & 1,56 \\
\hline 7 & 35 & 74,57 & 112 & 40 & 125 & 85 & 495,87 & 411,59 & 0,83 & 2,21 \\
\hline 8 & 39 & 71,82 & 107 & 40 & 126 & 86 & 467,38 & 383,10 & 0,82 & 2,13 \\
\hline 9 & 25 & 98,52 & 147 & 40 & 150 & 110 & 745,92 & 661,64 & 0,89 & 2,80 \\
\hline 10 & 42 & 63,45 & 95 & 34 & 100 & 66 & 172,88 & 88,60 & 0,51 & 1,03 \\
\hline 11 & 45 & 57,42 & 86 & 31 & 95 & 64 & 156,76 & 72,49 & 0,46 & 0,93 \\
\hline 12 & 39 & 75,10 & 112 & 43 & 136 & 93 & 668,92 & 584,64 & 0,87 & 2,63 \\
\hline 13 & 41 & 71,51 & 107 & 47 & 123 & 76 & 376,05 & 291,77 & 0,78 & 1,86 \\
\hline 14 & 24 & 71,92 & 108 & 38 & 130 & 92 & 357,07 & 272,79 & 0,76 & 1,80 \\
\hline 15 & 41 & 59,46 & 89 & 39 & 79 & 40 & 104,58 & 20,30 & 0,19 & 0,49 \\
\hline 16 & 38 & 71,50 & 107 & 37 & 123 & 86 & 469,50 & 385,22 & 0,82 & 2,14 \\
\hline 17 & 28 & 80,82 & 121 & 41 & 125 & 84 & 550,68 & 466,40 & 0,85 & 2,35 \\
\hline 18 & 42 & 57,95 & 87 & 40 & 93 & 53 & 141,77 & 57,49 & 0,41 & 0,83 \\
\hline 19 & 39 & 72,56 & 109 & 54 & 95 & 41 & 93,70 & 9,42 & 0,10 & 0,33 \\
\hline 20 & 44 & 61,34 & 92 & 34 & 86 & 52 & 124,29 & 40,01 & 0,32 & 0,69 \\
\hline 21 & 38 & 65,92 & 99 & 43 & 116 & 73 & 227,46 & 143,18 & 0,63 & 1,30 \\
\hline 22 & 42 & 61,67 & 92 & 46 & 82 & 36 & 123,79 & 39,52 & 0,32 & 0,68 \\
\hline 23 & 42 & 65,79 & 98 & 42 & 121 & 79 & 265,43 & 181,15 & 0,68 & 1,47 \\
\hline 24 & 44 & 64,16 & 96 & 34 & 101 & 67 & 169,78 & 85,50 & 0,50 & 1,01 \\
\hline 25 & 37 & 63,19 & 94 & 39 & 99 & 60 & 253,15 & 168,87 & 0,67 & 1,42 \\
\hline 26 & 45 & 67,18 & 100 & 40 & 102 & 62 & 280,10 & 195,82 & 0,70 & 1,52 \\
\hline 27 & 41 & 66,95 & 100 & 39 & 115 & 76 & 234,75 & 150,47 & 0,64 & 1,34 \\
\hline 28 & 44 & 65,02 & 97 & 39 & 99 & 60 & 173,76 & 89,48 & 0,51 & 1,03 \\
\hline 29 & 41 & 60,10 & 90 & 37 & 98 & 61 & 186,92 & 102,64 & 0,55 & 1,10 \\
\hline 30 & 43 & 58,91 & 88 & 39 & 84 & 45 & 103,74 & 19,46 & 0,19 & 0,48 \\
\hline 31 & 39 & 64,44 & 96 & 37 & 98 & 61 & 154,79 & 70,51 & 0,46 & 0,91 \\
\hline 32 & 43 & 59,33 & 89 & 39 & 120 & 81 & 299,79 & 215,51 & 0,72 & 1,60 \\
\hline 33 & 41 & 69,20 & 103 & 39 & 102 & 63 & 240,54 & 156,26 & 0,65 & 1,36 \\
\hline 34 & 44 & 56,50 & 84 & 34 & 77 & 43 & 85,82 & 1,55 & 0,02 & 0,14 \\
\hline 35 & 45 & 63,29 & 95 & 40 & 115 & 75 & 153,89 & 69,61 & 0,45 & 0,91 \\
\hline 36 & 44 & 77,45 & 116 & 37 & 121 & 84 & 623,44 & 539,17 & 0,86 & 2,53 \\
\hline 37 & 42 & 70,67 & 106 & 42 & 130 & 88 & 518,12 & 433,84 & 0,84 & 2,27 \\
\hline 38 & 40 & 65,85 & 98 & 47 & 132 & 85 & 293,21 & 208,93 & 0,71 & 1,57 \\
\hline 39 & 41 & 64,63 & 97 & 41 & 86 & 45 & 121,51 & 37,23 & 0,31 & 0,66 \\
\hline 40 & 42 & 67,95 & 102 & 38 & 101 & 63 & 196,01 & 111,73 & 0,57 & 1,15 \\
\hline 41 & 42 & 62,07 & 93 & 42 & 100 & 58 & 130,23 & 45,95 & 0,35 & 0,74 \\
\hline 42 & 43 & 53,35 & 80 & 30 & 89 & 59 & 140,79 & 56,51 & 0,40 & 0,82 \\
\hline 43 & 39 & 60,33 & 90 & 42 & 83 & 41 & 131,79 & 47,51 & 0,36 & 0,75 \\
\hline 44 & 44 & 61,86 & 93 & 37 & 110 & 73 & 250,04 & 165,76 & 0,66 & 1,40 \\
\hline 45 & 43 & 55,47 & 83 & 42 & 79 & 37 & 73,59 & $-10,69^{*}$ & $-0,15^{*}$ & $-*$ \\
\hline MEDIA F $2[4]$ & - & 66,87 & 100 & - & - & - & 271,18 & 187,14 & 0.69 & 1.49 \\
\hline Cristalina & 46 & 62,28 & 96 & 44 & $\overline{86}$ & 42 & 63,95 & - & - & - \\
\hline IAC-8 & 40 & 63,28 & 98 & 44 & 102 & 58 & 172,69 & - & - & - \\
\hline EMGOPA-301 & 38 & 78,03 & 120 & 46 & 100 & 54 & 132,30 & - & - & - \\
\hline SS-1 & 41 & 55,76 & 86 & 43 & 69 & 26 & 34,53 & - & $=$ & $=$ \\
\hline
\end{tabular}

$\begin{array}{llll}\text { TEDIA TESTEM } & - & 64,84 & 100\end{array}$ cálculo da média. ${ }^{a}$ Média aritmética de todos os valores individuais $(\mathrm{i}=1,2, \ldots, \mathrm{N})$. bVariância ponderada , conforme a freqüência de plantas $(n=1,2, \ldots, 12)$ e respectiva variância por repetição, com as quatro repetições. 
Tabela 13 APF: Altura da Planta no Florescimento $(\mathrm{cm})$ da geração $\mathbf{F}_{3: 2[4]}$ de 45 cruzamentos quádruplos, e de 4 testemunhas. Número de plantas $(N)$, média $\left(\bar{Y}_{i}\right)$, porcentagem em relação à média $(\%)$, valores minimos (Min.) e máximos (Max.), amplitude (Max. - Min.), variância fenotípica entre plantas $\left(\mathrm{S}_{\mathrm{d}}{ }_{\mathrm{d}}\right.$ ), variância genotípica $\left(\mathrm{S}_{\mathrm{g}}^{2}\right)$, herdabilidade no sentido amplo $\left(\mathrm{h}_{\mathrm{a}}^{2}\right)$ e relação entre os coeficientes de variação genética e ambiental (b). Soja Maracaí - SP (sem. 02/12/1993). VARIÂNCIA AMBIENTAL $\left(\mathrm{S}_{\mathrm{a}}^{2}\right)=59,12$.

\begin{tabular}{|c|c|c|c|c|c|c|c|c|c|c|}
\hline $\begin{array}{c}\text { POPULAÇÃO } \\
F_{3 \cdot 2141} \\
\end{array}$ & $\mathrm{~N}$ & $\bar{Y}_{i}^{a}$ & $(\%)$ & Min. & Max. & Ampl. & $\overline{\mathrm{S}^{2}{ }_{\mathrm{d}}}$ & $\bar{S}_{g}^{2-}$ & $\mathrm{h}_{\mathrm{a}}^{2-}$ & b \\
\hline 1 & 40 & 64,13 & 106 & 41 & 100 & 59 & 202,27 & 143,15 & 0,71 & 1,56 \\
\hline 2 & 36 & 62,11 & 103 & 41 & 89 & 48 & 160,80 & 101,68 & 0,63 & 1,31 \\
\hline 3 & 33 & 62,48 & 103 & 47 & 98 & 51 & 101,94 & 42,82 & 0,42 & 0,85 \\
\hline 4 & 38 & 62,45 & 103 & 40 & 98 & 58 & 191,00 & 131,88 & 0,69 & 1,49 \\
\hline 5 & 40 & 73,65 & 122 & 33 & 106 & 73 & 331,57 & 272,45 & 0,82 & 2,15 \\
\hline 6 & 36 & 72,39 & 120 & 43 & 111 & 68 & 126,44 & 67,32 & 0,53 & 1,07 \\
\hline 7 & 33 & 61,97 & 103 & 42 & 85 & 43 & 75,68 & 16,56 & 0,22 & 0,53 \\
\hline 8 & 37 & 70,97 & 117 & 32 & 125 & 93 & 395,63 & 336,51 & 0,85 & 2,39 \\
\hline 9 & 35 & 92,86 & 154 & 58 & 142 & 84 & 301,29 & 242,17 & 0,80 & 2,02 \\
\hline 10 & 36 & 58,08 & 96 & 26 & 86 & 60 & 184,58 & 125,46 & 0,68 & 1,46 \\
\hline 11 & 40 & 54,30 & 90 & 31 & 80 & 49 & 181,86 & 122,74 & 0,67 & 1,44 \\
\hline 12 & 41 & 69,10 & 114 & 32 & 110 & 78 & 323,04 & 263,92 & 0,82 & 2,11 \\
\hline 13 & 42 & 59,74 & 99 & 38 & 89 & 51 & 179,73 & 120,61 & 0,67 & 1,43 \\
\hline 14 & 42 & 56,48 & 93 & 25 & 110 & 85 & 248,44 & 189,32 & 0,76 & 1,79 \\
\hline 15 & 35 & 63,23 & 105 & 25 & 90 & 65 & 160,06 & 100,94 & 0,63 & 1,31 \\
\hline 16 & 41 & 61,93 & 102 & 33 & 115 & 82 & 259,39 & 200,27 & 0,77 & 1,84 \\
\hline 17 & 36 & 69,42 & 115 & 23 & 108 & 85 & 276,34 & 217,22 & 0,79 & 1,92 \\
\hline 18 & 41 & 56,15 & 93 & 25 & 88 & 63 & 152,28 & 93,16 & 0,61 & 1,26 \\
\hline 19 & 46 & 57,43 & 95 & 40 & 80 & 40 & 74,07 & 14,95 & 0,20 & 0,50 \\
\hline 20 & 38 & 59,50 & 98 & 38 & 100 & 62 & 136,31 & 77,19 & 0,57 & 1,14 \\
\hline 21 & 39 & 57,44 & 95 & 22 & 102 & 80 & 278,01 & 218,89 & 0,79 & 1,92 \\
\hline 22 & 38 & 56,11 & 93 & 40 & 77 & 37 & 96,15 & 37,03 & 0,39 & 0,79 \\
\hline 23 & 36 & 63,89 & 106 & 43 & 90 & 47 & 106,15 & 47,03 & 0,44 & 0,89 \\
\hline 24 & 37 & 61,68 & 102 & 38 & 91 & 53 & 204,52 & 145,40 & 0,71 & 1,57 \\
\hline 25 & 36 & 59,00 & 98 & 32 & 97 & 65 & 197,95 & 138,83 & 0,70 & 1,53 \\
\hline 26 & 35 & 59,34 & 98 & 38 & 79 & 41 & 151,83 & 92,71 & 0,61 & 1,25 \\
\hline 27 & 41 & 60,20 & 100 & 25 & 92 & 67 & 246,08 & 186,96 & 0,76 & 1,78 \\
\hline 28 & 41 & 61,68 & 102 & 35 & 96 & 61 & 205,90 & 146,78 & 0,71 & 1,58 \\
\hline 29 & 38 & 57,74 & 96 & 35 & 112 & 77 & 193,16 & 134,04 & 0,69 & 1,51 \\
\hline 30 & 39 & 47,59 & 79 & 28 & 66 & 38 & 96,47 & 37,35 & 0,39 & 0,79 \\
\hline 31 & 31 & 63,42 & 105 & 40 & 90 & 50 & 158,74 & 99,62 & 0,63 & 1,30 \\
\hline 32 & 42 & 49,36 & 82 & 20 & 97 & 77 & 324,46 & 265,34 & 0,82 & 2,12 \\
\hline 33 & 41 & 60,51 & 100 & 16 & 100 & 84 & 334,02 & 274,90 & 0,82 & 2,16 \\
\hline 34 & 43 & 53,77 & 89 & 23 & 70 & 47 & 88,10 & 28,98 & 0,33 & 0,70 \\
\hline 35 & 42 & 57,48 & 95 & 26 & 84 & 58 & 160,08 & 100,96 & 0,63 & 1,31 \\
\hline 36 & 36 & 62,36 & 103 & 27 & 99 & 72 & 420,33 & 361,21 & 0,86 & 2,47 \\
\hline 37 & 36 & 71,53 & 118 & 38 & 122 & 84 & 476,21 & 417,09 & 0,88 & 2,66 \\
\hline 38 & 43 & 51,88 & 86 & 30 & 89 & 59 & 156,10 & 96,98 & 0,62 & 1,28 \\
\hline 39 & 33 & 59,91 & 99 & 32 & 123 & 91 & 372,39 & 313,27 & 0,84 & 2,30 \\
\hline 40 & 44 & 60,07 & 99 & 27 & 86 & 59 & 118,38 & 59,26 & 0,50 & 1,00 \\
\hline 41 & 42 & 46,67 & 77 & 20 & 101 & 81 & 245,06 & 185,94 & 0,76 & 1,77 \\
\hline 42 & 42 & 49,52 & 82 & 18 & 92 & 74 & 258,63 & 199,51 & 0,77 & 1,84 \\
\hline 43 & 43 & 56,51 & 94 & 38 & 78 & 40 & 94,85 & 35,73 & 0,38 & 0,78 \\
\hline 44 & 39 & 57,51 & 95 & 36 & 94 & 58 & 185,72 & 126,60 & 0,68 & 1,46 \\
\hline 45 & 45 & 45,42 & 75 & 23 & 75 & 52 & 118,88 & 59,76 & 0,50 & 1,01 \\
\hline MEDIA F $_{3: 2[4]}$ & - & 60,42 & 100 & - & - & - & 207,80 & 148,68 & 0,72 & 1,58 \\
\hline Cristalina & 35 & 54,69 & 91 & 33 & 67 & 34 & 50,58 & - & - & - \\
\hline IAC-8 & 42 & 62,93 & 105 & 46 & 80 & 34 & 66,49 & - & - & - \\
\hline EMGOPA-301 & 30 & 70,93 & 118 & 47 & 90 & 43 & 94,18 & - & - & - \\
\hline SS-I & 42 & 52,24 & 87 & 30 & 63 & 33 & 38,56 & - & - & - \\
\hline MEDIA TESTEM & - & 60,20 & 100 & - & - & - & - & - & - & - \\
\hline
\end{tabular}

'Para identificar os cruzamentos que deram origem à estas populações $\mathrm{F}_{3 \mathrm{z}^{2}[4]}$, consultar o Apêndice 6 .

${ }^{2}$ Média aritmética de todos os valores individuais $(i=1,2, \ldots, N)$. Variância ponderada, conforme a freqüência de plantas $(n=1,2, \ldots, 12)$ e respectiva variância por repetição, com as quatro repetições. 
Tabela 14 NDM: Número de Dias para a Maturidade da geração $F_{2[4]}$ de 45 cruzamentos quádruplos, e de 4 testemunhas. Número de plantas $(N)$, média $\left(\bar{Y}_{\mathrm{i}}\right)$, porcentagem em relação à média $(\%)$, valores minimos $($ Mín.) e máximos (Max.), amplitude (Max. - Min.), variância fenotípica entre plantas $\left(\mathrm{S}_{\mathrm{d}}^{2}\right)$, variância genotipica $\left(\mathrm{S}_{\mathrm{g}}^{2}\right)$, herdabilidade no sentido amplo $\left(\mathrm{h}^{2}{ }_{\mathrm{a}}\right)$ e relação entre os coeficientes de variação genética e ambiental (b). Soja, Piracicaba - SP (sem. 04/12/92). VARIÂNCIA AMBIENTAL $\left(S_{a}^{2}\right)=41,31$.

\begin{tabular}{|c|c|c|c|c|c|c|c|c|c|c|}
\hline $\begin{array}{l}\text { POPULAÇÃO } \\
F_{2[4]} 1\end{array}$ & $\overline{\mathrm{N}}$ & $\overline{\bar{Y}_{i}^{\mathrm{a}}}$ & $(\%)$ & Min. & Max. & Ampl & $\mathrm{S}_{\mathrm{d}}^{2}$ & $\mathrm{~S}_{\mathrm{g}}^{2}$ & $\overline{\mathrm{h}_{\mathrm{a}}^{2}}$ & $\bar{b}$ \\
\hline 1 & 33 & 152 & 106 & 123 & 207 & $\overline{84}$ & 583,98 & 542,67 & 0,93 & 3,62 \\
\hline 2 & 42 & 143 & 100 & 117 & 178 & 61 & 168,62 & 127,31 & 0,76 & 1,76 \\
\hline 3 & 36 & 141 & 99 & 117 & 188 & 71 & 195,48 & 154,17 & 0,79 & 1,93 \\
\hline 4 & 36 & 149 & 104 & 117 & 195 & 78 & 255,51 & 214,20 & 0,84 & 2,28 \\
\hline 5 & 38 & 168 & 117 & 123 & 208 & 85 & 790,81 & 749,50 & 0,95 & 4,26 \\
\hline 6 & 40 & 160 & 112 & 123 & 195 & 72 & 302,87 & 261,56 & 0,86 & 2,52 \\
\hline 7 & 30 & 148 & 103 & 131 & 207 & 76 & 324,99 & 283,68 & 0,87 & 2,62 \\
\hline 8 & 38 & 149 & 104 & 123 & 207 & 84 & 459,80 & 418,49 & 0,91 & 3,18 \\
\hline 9 & 24 & 172 & 120 & 123 & 214 & 91 & 719,98 & 678,67 & 0,94 & 4,05 \\
\hline 10 & 42 & 146 & 102 & 119 & 205 & 86 & 276,44 & 235,13 & 0,85 & 2,39 \\
\hline 11 & 46 & 141 & 99 & 117 & 193 & 76 & 184,65 & 143,34 & 0,78 & 1,86 \\
\hline 12 & 38 & 148 & 103 & 117 & 205 & 88 & 372,67 & 331,36 & 0,89 & 2,83 \\
\hline 13 & 37 & 143 & 100 & 121 & 168 & 47 & 165,08 & 123,77 & 0,75 & 1,73 \\
\hline 14 & 23 & 149 & 104 & 119 & 188 & 69 & 210,34 & 169,03 & 0,80 & 2,02 \\
\hline 15 & 41 & 143 & 100 & 123 & 168 & 45 & 90,91 & 49,60 & 0,55 & 1,10 \\
\hline 16 & 36 & 146 & 102 & 13] & 199 & 68 & 321,91 & 280,60 & 0,87 & 2,61 \\
\hline 17 & 26 & 161 & 113 & 123 & 208 & 85 & 661,60 & 620,29 & 0,94 & 3.87 \\
\hline 18 & 39 & 143 & 100 & 131 & 162 & 31 & 90,15 & 48,84 & 0,54 & 1,09 \\
\hline 19 & 38 & 141 & 99 & 123 & 151 & 28 & 40,20 & $-1,11^{*}$ & $-0,03^{\circ}$ & $-{ }^{*}$ \\
\hline 20 & 42 & 137 & 96 & 123 & 168 & 45 & 66,87 & 25,56 & 0,38 & 0,79 \\
\hline 21 & 37 & 139 & 97 & 119 & 188 & 69 & 189,34 & 148,03 & 0,78 & 1,89 \\
\hline 22 & 42 & 139 & 97 & 123 & 161 & 38 & 89,86 & 48,55 & 0,54 & 1,08 \\
\hline 23 & 40 & 137 & 96 & 123 & 168 & 45 & 68,99 & 27,68 & 0,40 & 0,82 \\
\hline 24 & 44 & 135 & 94 & 110 & 214 & 104 & 199,91 & 158,60 & 0,79 & 1,96 \\
\hline 25 & 35 & 140 & 98 & 121 & 172 & 51 & 169,50 & 128,19 & 0,76 & 1,76 \\
\hline 26 & 44 & 140 & 98 & 123 & 168 & 45 & 73,80 & 32,49 & 0,44 & 0,89 \\
\hline 27 & 41 & 141 & 99 & 123 & 209 & 86 & 170,44 & 129,13 & 0,76 & 1,77 \\
\hline 28 & 43 & 142 & 99 & 119 & 161 & 42 & 122,76 & 81,45 & 0,66 & 1,40 \\
\hline 29 & 40 & 136 & 95 & 119 & 151 & 32 & 73,91 & 32,60 & 0,44 & 0,89 \\
\hline 30 & 42 & 129 & 90 & 110 & 151 & 41 & 116,80 & 75,49 & 0,65 & 1,35 \\
\hline 31 & 39 & 141 & 99 & 131 & 205 & 74 & 119,21 & 77,90 & 0,65 & 1,37 \\
\hline 32 & 43 & 135 & 94 & 117 & 199 & 82 & 399,15 & 357,84 & 0,90 & 2,94 \\
\hline 33 & 39 & 139 & 97 & 117 & 161 & 44 & 140,59 & 99,28 & 0,71 & 1,55 \\
\hline 34 & 40 & 133 & 93 & 123 & 151 & 28 & 56,05 & 14,74 & 0,26 & 0,60 \\
\hline 35 & 43 & 135 & 94 & 117 & 205 & 88 & 268,16 & 226,85 & 0,85 & 2,34 \\
\hline 36 & 44 & 148 & 103 & 117 & 205 & 88 & 508,68 & 467,37 & 0,92 & 3,36 \\
\hline 37 & 40 & 148 & 103 & 123 & 199 & 76 & 515,00 & 473,69 & 0,92 & 3,39 \\
\hline 38 & 40 & 135 & 94 & 117 & 205 & 88 & 339,32 & 298,01 & 0,88 & 2,69 \\
\hline 39 & 41 & 136 & 95 & 117 & 168 & 51 & 127,91 & 86,60 & 0,68 & 1,45 \\
\hline 40 & 42 & 144 & 101 & 123 & 168 & 45 & 97,69 & 56,38 & 0,58 & 1,17 \\
\hline 41 & 42 & 136 & 95 & 117 & 161 & 44 & 169,05 & 127,74 & 0,76 & 1,76 \\
\hline 42 & 41 & 133 & 93 & 117 & 168 & 51 & 180,68 & 139,37 & 0,77 & 1,84 \\
\hline 43 & 38 & 141 & 99 & 117 & 161 & 44 & 79,85 & 38,54 & 0,48 & 0,97 \\
\hline 44 & 41 & 140 & 98 & 119 & 195 & 76 & 277,49 & 236,18 & 0,85 & 2,39 \\
\hline 45 & 41 & 130 & 91 & 112 & 161 & 49 & 60,94 & 19,63 & 0,32 & 0,69 \\
\hline MEDIA $F_{2[4]}$ & - & 143 & 100 & - & - & - & 242,18 & 200,89 & 0,83 & 2.21 \\
\hline Cristalina & 45 & 149 & 105 & 139 & 178 & 39 & 46,13 & 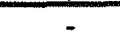 & - & - \\
\hline IAC-8 & 38 & 139 & 98 & 123 & 161 & 38 & 56,12 & - & - & - \\
\hline EMGOPA-301 & 36 & 151 & 106 & 131 & 168 & 37 & 57,11 & - & - & - \\
\hline SS-1 & 41 & 127 & 89 & 119 & 139 & 20 & 19,70 & - & - & - \\
\hline MEDIA TESTEM. & - & 142 & 100 & & & - & - & - & - & - \\
\hline
\end{tabular}

Para identificar os cruzamentos que deram origem à estas populações $F_{2[4]}$, consultar o Apêndice 6 . "Foi considerado valor 0 no cáteujo da média. ${ }^{\mathrm{a}}$ Média aritmética de todos os valores individuais $(\mathrm{i}=1,2, \ldots, \mathrm{N})$. ${ }^{\mathrm{b}} \mathrm{V}$ ariância ponderada, conforme a frequência de plantas $(n=1,2, \ldots 12)$ e respectiva variância por repetição, com as quatro repetições. 
Tabela 15 NDM: Número de Dias para a Maturidade da geração $\mathbf{F}_{3: 2[4]}$ de 45 cruzamentos quádruplos, e de 4 testemunhas. Número de plantas $(\mathrm{N})$, média $\left(\overline{\mathrm{Y}}_{\mathrm{i}}\right)$, porcentagem em relação à média $(\%)$, valores minimos (Min.) e máximos (Max.), amplitude (Max. - Min.), variância fenotipica entre plantas $\left(\mathrm{S}_{\mathrm{d}}{ }_{\mathrm{d}}\right.$ ), variância genotípica $\left(\mathrm{S}_{\mathrm{g}}^{2}\right)$, herdabilidade no sentido amplo $\left(\mathrm{h}_{\mathrm{a}}^{2}\right)$ e relação entre os coeficientes de variação genética e ambiental (b). Soja, Maracai - SP (sem. 02/12/1993). VARIÂNCIA AMBIENTAL $\left(\mathrm{S}^{2}{ }_{\mathrm{a}}\right)=13,97$.

\begin{tabular}{|c|c|c|c|c|c|c|c|c|c|c|}
\hline $\begin{array}{c}\text { POPULAÇẦO } \\
F_{3,224}\end{array}$ & $\mathrm{~N}$ & $\overline{Y_{i}^{2}}$ & $(\%)$ & Min. & Max. & Ampl. & $\mathrm{S}_{\mathrm{d}}^{2}$ & $\overrightarrow{\mathrm{S}}_{\mathrm{g}}^{2}$ & $\mathrm{~h}_{\mathrm{a}}^{2}$ & $\mathrm{~b}$ \\
\hline 1 & 41 & 143 & 107 & 117 & 203 & 86 & 674,01 & 660,04 & 0,98 & 6,87 \\
\hline 2 & 35 & 137 & 103 & 118 & 206 & 88 & 356,05 & 342,08 & 0,96 & 4,95 \\
\hline 3 & 33 & 132 & 99 & 117 & 166 & 49 & 83,60 & 69,63 & 0,83 & 2,23 \\
\hline 4 & 38 & 137 & 103 & 117 & 193 & 76 & 221,37 & 207,40 & 0,94 & 3,85 \\
\hline 5 & 40 & 156 & 117 & 117 & 217 & 100 & 1114,84 & 1100,87 & 0,99 & 8,88 \\
\hline 6 & 36 & 149 & 112 & 113 & 192 & 79 & 260,30 & 246,33 & 0,95 & 4,20 \\
\hline 7 & 34 & 132 & 99 & 117 & 170 & 53 & 107,05 & 93,08 & 0,87 & 2,58 \\
\hline 8 & 37 & 139 & 105 & 113 & 205 & 92 & 666,07 & 652,10 & 0,98 & 6,83 \\
\hline 9 & 35 & 156 & 117 & 121 & 199 & 78 & 408,32 & 394,35 & 0,97 & 5,31 \\
\hline 10 & 35 & 137 & 103 & 107 & 192 & 85 & 335,56 & 321,59 & 0,96 & 4,80 \\
\hline 11 & 40 & 132 & 99 & 109 & 190 & 81 & 317,58 & 303,61 & 0,96 & 4,66 \\
\hline 12 & 42 & 142 & 107 & 117 & 203 & 86 & 537,26 & 523,29 & 0,97 & 6,12 \\
\hline 13 & 42 & 135 & 101 & 113 & 204 & 91 & 363,97 & 350,00 & 0,96 & 5,01 \\
\hline 14 & 42 & 133 & 100 & 113 & 174 & 61 & 236,68 & 222,71 & 0,94 & 3,99 \\
\hline 15 & 35 & 135 & 101 & 117 & 202 & 85 & 233,57 & 219,60 & 0,94 & 3,96 \\
\hline 16 & 41 & 136 & 102 & 117 & 202 & 85 & 310,10 & 296,13 & 0,95 & 4,60 \\
\hline 17 & 36 & 148 & 111 & 117 & 203 & 86 & 684,01 & 670,04 & 0,98 & 6,93 \\
\hline 18 & 41 & 134 & 101 & 117 & 161 & 44 & 69,26 & 55,29 & 0,80 & 1,99 \\
\hline 19 & 46 & 132 & 99 & 117 & 174 & 57 & 102,37 & 88,40 & 0,86 & 2,52 \\
\hline 20 & 38 & 131 & 98 & 110 & 190 & 80 & 213,12 & 199,15 & 0,93 & 3,78 \\
\hline 21 & 39 & 130 & 98 & 109 & 172 & 63 & 158,84 & 144,87 & 0,91 & 3,22 \\
\hline 22 & 40 & 130 & 98 & 117 & 145 & 28 & 75,35 & 61,38 & 0,81 & 2,10 \\
\hline 23 & 36 & 131 & 98 & 117 & 154 & 37 & 71,48 & 57,51 & 0,80 & 2,03 \\
\hline 24 & 37 & 127 & 95 & 117 & 152 & 35 & 81,50 & 67,53 & 0,83 & 2,20 \\
\hline 25 & 36 & 135 & 101 & 117 & 182 & 65 & 290,62 & 276,65 & 0,95 & 4,45 \\
\hline 26 & 35 & 132 & 99 & 117 & 176 & 59 & 135,92 & 121,95 & 0,90 & 2,95 \\
\hline 27 & 41 & 129 & 97 & 107 & 193 & 86 & 216,82 & 202,85 & 0,94 & 3,81 \\
\hline 28 & 41 & 135 & 101 & 113 & 192 & 79 & 225,31 & 211,34 & 0,94 & 3,89 \\
\hline 29 & 38 & 127 & 95 & 117 & 149 & 32 & 43,09 & 29,12 & 0,68 & 1,44 \\
\hline 30 & 39 & 119 & 89 & 105 & 130 & 25 & 36,35 & 22,38 & 0,62 & 1,27 \\
\hline 31 & 31 & 132 & 99 & 117 & 190 & 73 & 228,35 & 214,38 & 0,94 & 3,92 \\
\hline 32 & 42 & 123 & 92 & 107 & 193 & 86 & 278,46 & 264,49 & 0,95 & 4,35 \\
\hline 33 & 41 & 127 & 95 & 102 & 160 & 58 & 136,80 & 122,83 & 0,90 & 2,97 \\
\hline 34 & 42 & 130 & 98 & 117 & 167 & 50 & 93,67 & 79,70 & 0,85 & 2,39 \\
\hline 35 & 42 & 125 & 94 & 113 & 168 & 55 & 111,53 & 97,56 & 0,87 & 2,64 \\
\hline 36 & 37 & 135 & 101 & 102 & 202 & 100 & 570,24 & 556,27 & 0,98 & 6,31 \\
\hline 37 & 36 & 143 & 107 & 102 & 217 & 115 & 898,68 & 884,71 & 0,98 & 7,96 \\
\hline 38 & 43 & 121 & 91 & 107 & 180 & 73 & 245,48 & 231,51 & 0,94 & 4,07 \\
\hline 39 & 33 & 125 & 94 & 109 & 161 & 52 & 118,76 & 104,79 & 0,88 & 2,74 \\
\hline 40 & 44 & 135 & 102 & 117 & 173 & 56 & 180,38 & 166,41 & 0,92 & 3,45 \\
\hline 41 & 43 & 125 & 94 & 100 & 193 & 93 & 179,63 & 165,66 & 0,92 & 3,44 \\
\hline 42 & 42 & 123 & 92 & 102 & 168 & 66 & 138,76 & 124,79 & 0,90 & 2,99 \\
\hline 43 & 43 & 134 & 101 & 113 & 163 & 50 & 104,80 & 90,83 & 0,87 & 2,55 \\
\hline 44 & 39 & 132 & 99 & 102 & 204 & 102 & 407,39 & 393,42 & 0,97 & 5,31 \\
\hline 45 & 45 & 124 & 93 & 107 & 137 & 30 & 44,55 & 30,58 & 0,69 & 1,48 \\
\hline MEDIA F $_{3: 2[4]}$ & - & 133 & 100 & - & - & - & 274,84 & 260,87 & 0,95 & 4,32 \\
\hline Cristalina & 35 & 135 & 103 & 126 & 148 & 22 & 15,60 & - & $=$ & - \\
\hline IAC-8 & 42 & 128 & 98 & 123 & 137 & 14 & 16,87 & - & - & - \\
\hline EMGOPA-301 & 30 & 143 & 109 & 126 & 168 & 42 & 109,57 & - & - & - \\
\hline SS-1 & 43 & 117 & 89 & 113 & 117 & 4 & 1,32 & - & - & - \\
\hline MEDIA TESTEM & - & 131 & 100 & - & - & - & - & - & $=$ & - \\
\hline
\end{tabular}

'Para identificar os cruzamentos que deram origem à estas populaçōes $\mathrm{F}_{3: 2[4]}$, consultar o Apêndice 6 .

Média aritmética de todos os valores individuais $(\mathrm{i}=1,2, \ldots, \mathrm{N})$. plantas $(n=1,2, \ldots, 12)$ e respectiva variância por repetição, com as quatro repetições. 
Tabela 16 APM: Altura da Planta na Maturidade $(\mathrm{cm})$ da geração $\mathbf{F}_{2[4]}$ de 45 cruzamentos quádruplos, e de 4 testemunhas. Número de plantas $(\mathrm{N})$, média $\left(\overline{\mathrm{Y}}_{\mathrm{i}}\right)$, porcentagem em relação à média $(\%)$, valores minimos (Mín.) e máximos (Max.), amplitude (Max. - Min.), variância fenotípica entre plantas $\left(\mathrm{S}_{\mathrm{d}}^{2}\right.$ ), variância genotipica $\left(\mathrm{S}_{\mathrm{g}}^{2}\right)$, herdabilidade no sentido amplo $\left(\mathrm{h}^{2}{ }_{\mathrm{a}}\right)$ e relação entre os coeficientes de variação genética $\mathrm{e}$ ambiental (b). Soja, Piracicaba - SP (sem. 04/12/1992). VARIÂNCIA AMBIENTAL $\left(\mathrm{S}^{2}{ }_{\mathrm{a}}\right)=75,38$.

\begin{tabular}{|c|c|c|c|c|c|c|c|c|c|c|}
\hline $\begin{array}{c}\text { POPULAÇÁO } \\
F_{2[4]}\end{array}$ & $\mathbf{N}$ & $\bar{Y}_{i}^{2}$ & (\%) & Min. & Max. & Ampl. & $\mathrm{S}_{\mathrm{d}}^{2} \mathrm{~b}$ & $\overline{\mathrm{S}_{g}^{2}}$ & $\overline{h^{2}}$ & $\mathrm{~b}$ \\
\hline 1 & 33 & 80,27 & 92 & 50 & 120 & 70 & 506,52 & 431,14 & 0,85 & 2,39 \\
\hline 2 & 42 & 85,45 & 98 & 60 & 110 & 50 & 229,78 & 154,40 & 0,67 & 1,43 \\
\hline 3 & 36 & 98,22 & 113 & 60 & 130 & 70 & 308,22 & 232,84 & 0,76 & 1,76 \\
\hline 4 & 36 & 84,89 & 97 & 60 & 130 & 70 & 221,90 & 146,52 & 0,66 & 1,39 \\
\hline 5 & 38 & 95,63 & 110 & 51 & 131 & 80 & 564,66 & 489,28 & 0,87 & 2,55 \\
\hline 6 & 40 & 95,70 & 110 & 65 & 124 & 59 & 165,67 & 90,29 & 0,54 & 1,09 \\
\hline 7 & 30 & 85,47 & 98 & 50 & 130 & 80 & 334,91 & 259,53 & 0,77 & 1,86 \\
\hline 8 & 38 & 88,63 & 102 & 50 & 135 & 85 & 421,79 & 346,41 & 0,82 & 2,14 \\
\hline 9 & 24 & 124,71 & 143 & 60 & 185 & 125 & 728,53 & 653,15 & 0,90 & 2,94 \\
\hline 10 & 42 & 78,81 & 90 & 45 & 120 & 75 & 211,96 & 136,58 & 0,64 & 1,35 \\
\hline 11 & 45 & 79,71 & 91 & 45 & 130 & 85 & 415,60 & 340,22 & 0,82 & 2,12 \\
\hline 12 & 38 & 85,79 & 98 & 55 & 145 & 90 & 453,41 & 378,03 & 0,83 & 2,24 \\
\hline 13 & 37 & 88,19 & 101 & 50 & 160 & 110 & 516,41 & 441,03 & 0,85 & 2,42 \\
\hline 14 & 23 & 81,78 & 94 & 42 & 115 & 73 & 266,87 & 191,49 & 0,72 & 1,59 \\
\hline 15 & 41 & 80,98 & 93 & 50 & 125 & 75 & 216,28 & 140,90 & 0,65 & 1,37 \\
\hline 16 & 36 & 92,47 & 106 & 60 & 140 & 80 & 385,48 & 310,10 & 0,80 & 2,03 \\
\hline 17 & 26 & 101,50 & 116 & 45 & 145 & 100 & 715,25 & 639,87 & 0,89 & 2,91 \\
\hline 18 & 39 & 94,90 & 109 & 65 & 120 & 55 & 233,50 & 158,12 & 0,68 & 1,45 \\
\hline 19 & 39 & 89,26 & 102 & 67 & 113 & 46 & 131,32 & 55,94 & 0,43 & 0,86 \\
\hline 20 & 42 & 77,05 & 88 & 55 & 110 & 55 & 154,54 & 79,16 & 0,51 & 1,02 \\
\hline 21 & 37 & 78,14 & 90 & 56 & 110 & 54 & 215,62 & 140,24 & 0,65 & 1,36 \\
\hline 22 & 42 & 79,69 & 91 & 50 & 105 & 55 & 222,29 & 146,91 & 0,66 & 1,40 \\
\hline 23 & 40 & 86,30 & 99 & 60 & 187 & 127 & 462,48 & 387,10 & 0,84 & 2,27 \\
\hline 24 & 44 & 91,21 & 105 & 55 & 131 & 76 & 451,03 & 375,65 & 0,83 & 2,23 \\
\hline 25 & 35 & 95,09 & 109 & 47 & 140 & 93 & 629,91 & 554,53 & 0,88 & 2,71 \\
\hline 26 & 44 & 98,52 & 113 & 45 & 135 & 90 & 485,57 & 410,19 & 0,84 & 2,33 \\
\hline 27 & 41 & 82,07 & 94 & 48 & 130 & 82 & 352,11 & 276,73 & 0,79 & 1,92 \\
\hline 28 & 43 & 92,79 & 106 & 51 & 140 & 89 & 565,35 & 489,97 & 0,87 & 2,55 \\
\hline 29 & 40 & 92,03 & 105 & 45 & 140 & 95 & 552,58 & 477,20 & 0,86 & 2,52 \\
\hline 30 & 42 & 79,91 & 92 & 47 & 115 & 68 & 296,46 & 221,08 & 0,75 & 1,71 \\
\hline 31 & 39 & 79,10 & 91 & 45 & 135 & 90 & 316,42 & 241,04 & 0,76 & 1,79 \\
\hline 32 & 43 & 81,33 & 93 & 44 & 140 & 96 & 746,71 & 671,33 & 0,90 & 2,98 \\
\hline 33 & 39 & 96,56 & 111 & 55 & 140 & 85 & 563,17 & 487,79 & 0,87 & 2,54 \\
\hline 34 & 41 & 92,05 & 106 & 55 & 130 & 75 & 468,92 & 393,54 & 0,84 & 2,28 \\
\hline 35 & 43 & 83,65 & 96 & 41 & 130 & 89 & 412,31 & 336,93 & 0,82 & 2,11 \\
\hline 36 & 44 & 91,21 & 105 & 44 & 140 & 96 & 715,07 & 639,69 & 0,89 & 2,91 \\
\hline 37 & 40 & 87,65 & 100 & 55 & 135 & 80 & 430,42 & 355,04 & 0,82 & 2,17 \\
\hline 38 & 40 & 75,20 & 86 & 50 & 120 & 70 & 245,62 & 170,24 & 0,69 & 1,50 \\
\hline 39 & 41 & 86,51 & 99 & 46 & 130 & 84 & 535,12 & 459,74 & 0,86 & 2,47 \\
\hline 40 & 42 & 83,48 & 96 & 60 & 110 & 50 & 216,76 & 141,38 & 0,65 & 1,37 \\
\hline 41 & 42 & 77,50 & 89 & 43 & 130 & 87 & 430,76 & 355,38 & 0,83 & 2,17 \\
\hline 42 & 42 & 69,12 & 79 & 35 & 135 & 100 & 509,66 & 434,28 & 0,85 & 2,40 \\
\hline 43 & 38 & 93,05 & 107 & 51 & 145 & 94 & 578,43 & 503,05 & 0,87 & 2,58 \\
\hline 44 & 43 & 83,54 & 96 & 53 & 115 & 62 & 207,35 & 131,97 & 0,64 & 1,32 \\
\hline 45 & 42 & 81,05 & 93 & 45 & 115 & 70 & 354,88 & 279,50 & 0,79 & 1,93 \\
\hline MEDIA F $_{2[4]}$ & E & 87,25 & 100 & - & - & - & 403,28 & 327,90 & 0,81 & 2,09 \\
\hline Cristalina & 45 & 81,09 & 97 & 58 & 90 & 32 & 43,97 & - & - & - \\
\hline IAC-8 & 38 & 78,84 & 94 & 55 & 100 & 45 & 113,47 & - & - & - \\
\hline EMGOPA-301 & 36 & 96,39 & 115 & 65 & 130 & 65 & 199,87 & - & - & - \\
\hline SS-1 & 41 & 78,05 & 93 & 63 & 95 & 32 & 32,37 & - & - & - \\
\hline MEDIA TESTEM & - & 83,59 & 100 & - & 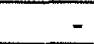 & - & - & - & - & - \\
\hline
\end{tabular}

TPara identificar os cruzamentos que deram origem à estas populações $\mathrm{F}_{2[4]}$, consultar o Apêndice 6 .

${ }^{2}$ Média aritmética de todos os valores individuais $(i=1,2, \ldots, N)$. Variância ponderada, conforme a frequêencia de plantas $(n=1,2, \ldots, 12)$ e respectiva variància por repetição, com as quatro repetições. 
Tabela 17 APM: Altura da Planta na Maturidade $(\mathrm{cm})$ da geração $F_{3: 2[4]}$ de 45 cruzamentos quádruplos, e de 4 testemunhas. Número de plantas $(\mathrm{N})$, média $\left(\overline{\mathrm{Y}}_{\mathrm{i}}\right)$, porcentagem em relação à média $(\%)$, valores minimos (Mín.) e máximos (Max.), amplitude (Max. - Min.), variância fenotípica entre plantas $\left(\mathrm{S}_{\mathrm{d}}^{2}\right.$ ), variância genotipica $\left(\mathrm{S}_{\mathrm{g}}^{2}\right)$, herdabilidade no sentido amplo $\left(\mathrm{h}_{\mathrm{a}}^{2}\right)$ e relação entre os coeficientes de variação genética e ambiental (b). Soja, Maracaí - SP (sem. 02/12/1993). VARIÂNCIA AMBIENTAL $\left(S^{2}{ }_{a}\right)=67,80$.

\begin{tabular}{|c|c|c|c|c|c|c|c|c|c|c|}
\hline $\begin{array}{c}\text { POPULAÇÃO } \\
F_{3: 2141}\end{array}$ & $N$ & $\bar{Y}_{i}^{a}$ & $(\%)$ & Min. & Max. & Ampl. & $\vec{S}_{d}^{2}$ & $\overline{\mathrm{S}}_{\mathrm{g}}^{2-}$ & $\mathrm{h}_{\mathrm{a}}^{2-}$ & b \\
\hline 1 & 41 & 73,63 & 99 & 42 & 123 & 81 & 312,39 & 244,59 & 0,78 & 1,90 \\
\hline 2 & 35 & 71,71 & 97 & 49 & 103 & 54 & 179,83 & 112,03 & 0,62 & 1,29 \\
\hline 3 & 33 & 90,76 & 122 & 56 & 129 & 73 & 340,35 & 272,55 & 0,80 & 2,00 \\
\hline 4 & 38 & 71,11 & 96 & 44 & 103 & 59 & 273,87 & 206,07 & 0,75 & 1,74 \\
\hline 5 & 40 & 80,25 & 108 & 33 & 117 & 84 & 481,35 & 413,55 & 0,86 & 2,47 \\
\hline 6 & 36 & 83,58 & 113 & 43 & 120 & 77 & 176,61 & 108,81 & 0,62 & 1,27 \\
\hline 7 & 34 & 73,68 & 99 & 43 & 106 & 63 & 155,16 & 87,36 & 0,56 & 1,14 \\
\hline 8 & 37 & 84,03 & 113 & 40 & 144 & 104 & 584,33 & 516,53 & 0,88 & 2,76 \\
\hline 9 & 35 & 121,83 & 164 & 79 & 173 & 94 & 732,56 & 664,76 & 0,91 & 3,13 \\
\hline 10 & 35 & 65,83 & 89 & 22 & 99 & 77 & 277,31 & 209,51 & 0,76 & 1,76 \\
\hline 11 & 40 & 71,28 & 96 & 35 & 127 & 92 & 462,04 & 394,24 & 0,85 & 2,41 \\
\hline 12 & 42 & 83,10 & 112 & 43 & 186 & 143 & 878,63 & 810,82 & 0,92 & 3,46 \\
\hline 13 & 42 & 69,05 & 93 & 40 & 107 & 67 & 322,15 & 254,35 & 0,79 & 1,94 \\
\hline 14 & 42 & 67,07 & 90 & 25 & 130 & 105 & 386,22 & 318,41 & 0,82 & 2,17 \\
\hline 15 & 35 & 71,97 & 97 & 26 & 108 & 82 & 237,06 & 169,26 & 0,71 & 1,58 \\
\hline 16 & 41 & 71,44 & 96 & 45 & 132 & 87 & 340,14 & 272,34 & 0,80 & 2,00 \\
\hline 17 & 36 & 84,50 & 114 & 27 & 130 & 103 & 510,40 & 442,60 & 0,87 & 2,55 \\
\hline 18 & 41 & 84,20 & 114 & 40 & 140 & 100 & 492,31 & 424,51 & 0,86 & 2,50 \\
\hline 19 & 46 & 66,96 & 90 & 39 & 84 & 45 & 90,39 & 22,59 & 0,25 & 0,58 \\
\hline 20 & 38 & 66,00 & 89 & 42 & 110 & 68 & 212,85 & 145,05 & 0,68 & 1,46 \\
\hline 21 & 39 & 66,00 & 89 & 30 & 116 & 86 & 353,20 & 285,40 & 0,81 & 2,05 \\
\hline 22 & 40 & 64,70 & 87 & 42 & 89 & 47 & 171,33 & 103,53 & 0,60 & 1,24 \\
\hline 23 & 36 & 74,28 & 100 & 50 & 115 & 65 & 146,16 & 78,36 & 0,54 & 1,08 \\
\hline 24 & 37 & 81,35 & 110 & 41 & 137 & 96 & 613,87 & 546,07 & 0,89 & 2,84 \\
\hline 25 & 36 & 83,11 & 112 & 43 & 135 & 92 & 683,83 & 616,03 & 0,91 & 3,01 \\
\hline 26 & 35 & 72,60 & 98 & 40 & 123 & 83 & 391,45 & 323,65 & 0,83 & 2,18 \\
\hline 27 & 41 & 69,10 & 93 & 29 & 100 & 71 & 403,34 & 335,53 & 0,83 & 2,22 \\
\hline 28 & 41 & 80,39 & 108 & 35 & 157 & 122 & 817,83 & 750,03 & 0,92 & 3,33 \\
\hline 29 & 38 & 82,37 & 111 & 38 & 162 & 124 & 642,47 & 574,67 & 0,89 & 2,91 \\
\hline 30 & 39 & 64,21 & 87 & 31 & 99 & 68 & 290,78 & 222,98 & 0,77 & 1,81 \\
\hline 31 & 31 & 68,39 & 92 & 42 & 110 & 68 & 267,35 & 199,55 & 0,75 & 1,72 \\
\hline 32 & 42 & 59,76 & 81 & 22 & 139 & 117 & 670,79 & 602,99 & 0,90 & 2,98 \\
\hline 33 & 41 & 76,93 & 104 & 20 & 128 & 108 & 705,23 & 637,43 & 0,90 & 3,07 \\
\hline 34 & 42 & 81,98 & 111 & 35 & 126 & 91 & 483,29 & 415,49 & 0,86 & 2,48 \\
\hline 35 & 42 & 72,02 & 97 & 26 & 114 & 88 & 389,53 & 321,73 & 0,83 & 2,18 \\
\hline 36 & 37 & 68,70 & 93 & 27 & 110 & 83 & 582,98 & 515,18 & 0,88 & 2,76 \\
\hline 37 & 36 & 80,56 & 109 & 40 & 146 & 106 & 615,22 & 547,41 & 0,89 & 2,84 \\
\hline 38 & 43 & 59,30 & 80 & 25 & 106 & 81 & 210,32 & 142,52 & 0,68 & 1,45 \\
\hline 39 & 33 & 73,79 & 99 & 40 & 160 & 120 & 866,72 & 798,92 & 0,92 & 3,43 \\
\hline 40 & 44 & 70,14 & 95 & 47 & 110 & 63 & 166,06 & 98,26 & 0,59 & 1,20 \\
\hline 41 & 43 & 63,47 & 86 & 20 & 159 & 139 & 794,09 & 726,29 & 0,91 & 3,27 \\
\hline 42 & 42 & 55,48 & 75 & 22 & 119 & 97 & 492,71 & 424,91 & 0,86 & 2,50 \\
\hline 43 & 43 & 83,12 & 112 & 40 & 125 & 85 & 445,72 & 377,92 & 0,85 & 2,36 \\
\hline 44 & 39 & 71,72 & 97 & 40 & 115 & 75 & 277,81 & 210,01 & 0,76 & 1,76 \\
\hline 45 & 45 & 62,13 & 84 & 26 & 123 & 97 & 432,36 & 364,56 & 0,84 & 2,32 \\
\hline MEDIA F $_{3: 2[4]}$ & - & 74,17 & 100 & - & - & - & 430,23 & 362,43 & 0,84 & 2,31 \\
\hline Cristalina & 35 & 65,60 & 94 & 44 & 80 & 36 & 66,37 & - & - & - \\
\hline IAC-8 & 41 & 71,10 & 102 & 51 & 91 & 40 & 85,99 & - & - & - \\
\hline ENGOPA-301 & 30 & 79,80 & 115 & 57 & 98 & 41 & 94,01 & - & - & - \\
\hline SS-1 & 43 & 61,91 & 89 & 37 & 74 & 37 & 39,39 & - & - & - \\
\hline MÉDIA TESTEM & - & 69,60 & 100 & - & $=$ & - & & - & - & - \\
\hline
\end{tabular}

TPara identificar os cruzamentos que deram origem à estas populações $\mathrm{F}_{3: 2[4]}$, consultar o Apêndice 6 .

${ }^{a}$ Média aritmética de todos os valores individuais $(i=1,2, \ldots, N)$. Variância ponderada, conforme a frequência de plantas $(n=1,2, \ldots, 12)$ e respectiva variância por repetição, com as quatro repetições. 
Tabela 18 VA: Valor Agronòmico (nota $1=$ péssimo a $S=$ excelente) da geração $\mathbf{F}_{2[4]}$ de 45 cruzamentos quádruplos, e de 4 testemunhas. Número de plantas $(\mathrm{N})$, média $\left(\bar{Y}_{\mathrm{i}}\right)$, porcentagem em relação à média $(\%)$, valores mínimos (Min.) e máximos (Max.), amplitude (Max .- Min.), variância fenotípica entre plantas $\left(\mathrm{S}_{\mathrm{d}}^{2}\right)$, variância genotípica $\left(\mathrm{S}_{\mathrm{g}}^{2}\right)$, herdabilidade no sentido amplo $\left(\mathrm{h}_{\mathrm{a}}^{2}\right)$ e relação entre os coeficientes de variação genética e ambiental (b). Soja, Piracicaba (sem. 04/12/1992). VARIÂNCIA AMBIENTAL $\left(\mathrm{S}_{\mathrm{a}}^{2}\right)=0,58$.

\begin{tabular}{|c|c|c|c|c|c|c|c|c|c|c|}
\hline $\begin{array}{c}\text { POPULAÇÃO } \\
F_{2|4|} \\
\end{array}$ & $\bar{N}$ & $\overline{\bar{Y}_{i}^{2}}$ & $(\%)$ & Min. & Max. & Ampl. & $\mathrm{S}_{\mathrm{d}}^{2 \mathrm{~b}}$ & $\mathrm{~S}_{\mathrm{g}}^{2}$ & $\overline{h^{2}}$ & $\mathrm{~b}$ \\
\hline 1 & 33 & 3,52 & 90 & 2 & 5 & 3 & 1,19 & 0,60 & 0,50 & 1,02 \\
\hline 2 & 42 & 4,17 & 107 & 2 & 5 & 3 & 0,91 & 0,32 & 0,35 & 0,74 \\
\hline 3 & 35 & 3,69 & 95 & 2 & 5 & 3 & 1,06 & 0,47 & 0,44 & 0,90 \\
\hline 4 & 36 & 4,03 & 104 & 3 & 5 & 2 & 0,75 & 0,17 & 0,23 & 0,54 \\
\hline 5 & 38 & 4,26 & 110 & 3 & 5 & 2 & 0,53 & $-0,06^{*}$ & $-0,11^{*}$ & - \\
\hline 6 & 40 & 4,45 & 114 & 2 & 5 & 3 & 0,61 & 0,02 & 0,03 & 0,19 \\
\hline 7 & 29 & 3,83 & 98 & 2 & 5 & 3 & 0,98 & 0,40 & 0,41 & 0,83 \\
\hline 8 & 38 & 4,16 & 107 & 2 & 5 & 3 & 0,84 & 0,26 & 0,31 . & 0,67 \\
\hline 9 & 24 & 3,50 & 90 & 2 & 5 & 3 & 0,34 & $-0,24^{*}$ & $-0,71^{*}$ & $\because$ \\
\hline 10 & 42 & 3,86 & 99 & 2 & 5 & 3 & 0,75 & 0,17 & 0,23 & 0,54 \\
\hline 11 & 45 & 3,56 & 91 & 2 & 5 & 3 & 0,97 & 0,39 & 0,40 & 0,82 \\
\hline 12 & 38 & 4,00 & 103 & 1 & 5 & 4 & 0,91 & 0,32 & 0,35 & 0,74 \\
\hline 13 & 37 & 3,95 & 101 & 2 & 5 & 3 & 0,90 & 0,31 & 0,34 & 0,73 \\
\hline 14 & 23 & 4,13 & 106 & 2 & 5 & 3 & 0,74 & 0,16 & 0,22 & 0,53 \\
\hline 15 & 41 & 3,85 & 99 & 2 & 5 & 3 & 1,13 & 0,55 & 0,49 & 0,97 \\
\hline 16 & 36 & 4,31 & 111 & 3 & 5 & 2 & 0,41 & $-0,17^{*}$ & $-0,41^{*}$ & $\because$ \\
\hline 17 & 26 & 4,04 & 104 & 2 & 5 & 3 & 1,14 & 0,56 & 0,49 & 0,98 \\
\hline 18 & 39 & 3,69 & 95 & 2 & 5 & 3 & 0,76 & 0,18 & 0,24 & 0,56 \\
\hline 19 & 38 & 4,53 & 116 & 3 & 5 & 2 & 0,34 & $-0,25^{*}$ & $-0,74^{*}$ & - \\
\hline 20 & 42 & 4,07 & 105 & 2 & 5 & 3 & 0,67 & 0,08 & 0,12 & 0,37 \\
\hline 21 & 37 & 4,22 & 108 & 2 & 5 & 3 & 0,51 & $-0,07^{*}$ & $-0,14^{*}$ & - \\
\hline 22 & 42 & 4,24 & 109 & 2 & 5 & 3 & 0,73 & 0,15 & 0,21 & 0,51 \\
\hline 23 & 39 & 4,15 & 107 & 2 & 5 & 3 & 1,13 & 0,54 & 0,48 & 0,96 \\
\hline 24 & 43 & 3,58 & 92 & 2 & 5 & 3 & 0,83 & 0,24 & 0,29 & 0,64 \\
\hline 25 & 34 & 3,71 & 95 & 2 & 5 & 3 & 0,60 & 0,01 & 0,02 & 0,13 \\
\hline 26 & 44 & 4,07 & 105 & 2 & 5 & 3 & 0,77 & 0,18 & 0,23 & 0,56 \\
\hline 27 & 41 & 3,90 & 100 & 2 & 5 & 3 & 0,71 & 0,13 & 0,18 & 0,47 \\
\hline 28 & 43 & 3,93 & 101 & 2 & 5 & 3 & 0,88 & 0,30 & 0,34 & 0,72 \\
\hline 29 & 40 & 3,88 & 100 & 2 & 5 & 3 & 0,95 & 0,37 & 0,39 & 0,80 \\
\hline 30 & 42 & 3,48 & 89 & 2 & 5 & 3 & 0,75 & 0,16 & 0,21 & 0,53 \\
\hline 31 & 38 & 4,13 & 106 & 3 & 5 & 2 & 0,69 & 0,11 & 0,16 & 0,44 \\
\hline 32 & 43 & 3,42 & 88 & 2 & 5 & 3 & 0,99 & 0,40 & 0,40 & 0,83 \\
\hline 33 & 39 & 3,82 & 98 & 2 & 5 & 3 & 0,97 & 0,39 & 0,40 & 0,82 \\
\hline 34 & 40 & 3,53 & 91 & 2 & 5 & 3 & 1,07 & 0,49 & 0,46 & 0,92 \\
\hline 35 & 43 & 3,67 & 94 & 2 & 5 & 3 & 1,15 & 0,56 & 0,49 & 0,98 \\
\hline 36 & 44 & 4,23 & 109 & 2 & 5 & 3 & 0,79 & 0,21 & 0,27 & 0,60 \\
\hline 37 & 40 & 4,38 & 112 & 1 & 5 & 4 & 0,94 & 0,36 & 0,38 & 0,79 \\
\hline 38 & 39 & 3,38 & 87 & 2 & 5 & 3 & 0,96 & 0,38 & 0,40 & 0,81 \\
\hline 39 & 40 & 3,68 & 94 & 2 & 5 & 3 & 0,95 & 0,36 & 0,38 & 0,79 \\
\hline 40 & 42 & 4,33 & 111 & 3 & 5 & 2 & 0,60 & 0,02 & 0,03 & 0,19 \\
\hline 41 & 42 & 3,45 & 89 & 2 & 5 & 3 & 1,13 & 0,54 & 0,48 & 0,96 \\
\hline 42 & 41 & 3,20 & 82 & 2 & 5 & 3 & 1,07 & 0,48 & 0,45 & 0,91 \\
\hline 43 & 38 & 3,84 & 99 & 2 & 5 & 3 & 0,95 & 0,37 & 0,39 & 0,80 \\
\hline 44 & 43 & 3,86 & 99 & 2 & 5 & 3 & 1,11 & 0,53 & 0,48 & 0,96 \\
\hline 45 & 41 & 3,37 & 87 & 2 & 5 & 3 & 0,64 & 0,06 & 0,09 & 0,32 \\
\hline MEDIA F $_{2[4]}$ & - & 3,89 & 100 & - & - & - & 0,84 & 0,27 & 0,32 & 0,68 \\
\hline Cristalina & 45 & 4,38 & 105 & 2 & 5 & 3 & 0,47 & - & - & - \\
\hline IAC-8 & 38 & 3,74 & 89 & 2 & 5 & 3 & 0,82 & - & - & - \\
\hline EMGOPA-301 & 36 & 4,56 & 109 & 2 & 5 & 3 & 0,57 & - & - & - \\
\hline SS-1 & 41 & 4,02 & 96 & 2 & 5 & 3 & 0,53 & - & - & - \\
\hline
\end{tabular}


Tabela 19 VA: Valor Agronòmico (nota $l=$ péssimo a $5=$ excelente) da geração $\mathbf{F}_{3: 2[4]}$ de 45 cruzamentos quádruplos, e de 4 testemunhas. Número de plantas $(\mathrm{N})$, média $\left(\overline{\mathrm{Y}}_{\mathrm{i}}\right)$, porcentagem em relação à média $(\%)$, valores mínimos (Min.) e máximos (Max.), amplitude (Max - Min.), variância fenotípica entre plantas $\left(\mathrm{S}_{\mathrm{d}}^{2}\right.$ ), variância genotípica $\left(\mathrm{S}_{\mathrm{g}}^{2}\right)$, herdabilidade no sentido amplo $\left(\mathrm{h}_{\mathrm{a}}{ }_{\mathrm{a}}\right)$ e relação entre os coeficientes de variação genética e ambiental (b). Soja, Maracai-SP (sem. 02/12/1993). VARIÂNCIA AMBIENTAL $\left(\mathrm{S}_{\mathrm{a}}^{2}\right)=0,54$.

\begin{tabular}{|c|c|c|c|c|c|c|c|c|c|c|}
\hline $\begin{array}{c}\text { POPULAÇÃO } \\
F_{3: 2[4]} \\
\end{array}$ & $\bar{N}$ & $\overline{Y_{i}^{a}}$ & $(\%)$ & Min. & Max. & Ampl. & $\mathrm{S}_{\mathrm{d}}^{2}$ & $\mathrm{~S}_{\mathrm{g}}^{2}$ & $\mathrm{~h}_{\mathrm{a}}^{2}$ & $\bar{b}$ \\
\hline 1 & 40 & 3,40 & 90 & 2 & $\overline{5}$ & 3 & 0,55 & 0,01 & 0,02 & 0,14 \\
\hline 2 & 35 & 3,77 & 100 & 2 & 5 & 3 & 0,90 & 0,36 & 0,40 & 0,82 \\
\hline 3 & 33 & 3,79 & 100 & 2 & 5 & 3 & 0,68 & 0,13 & 0,19 & 0,49 \\
\hline 4 & 38 & 3,89 & 103 & 2 & 5 & 3 & 0,69 & 0,15 & 0,22 & 0,53 \\
\hline 5 & 40 & 3,78 & 100 & 2 & 5 & 3 & 0,79 & 0,25 & 0,32 & 0,68 \\
\hline 6 & 36 & 4,06 & 107 & 2 & 5 & 3 & 0,75 & 0,20 & 0,27 & 0,61 \\
\hline 7 & 34 & 3,82 & 101 & 2 & 5 & 3 & 0,97 & 0,43 & 0,44 & 0,89 \\
\hline 8 & 37 & 3,89 & 103 & 2 & 5 & 3 & 0,53 & $-0,02^{*}$ & $-0,04^{*}$ & $\therefore$ \\
\hline 9 & 35 & 3,63 & 96 & 2 & 5 & 3 & 0,69 & 0,15 & 0,22 & 0,53 \\
\hline 10 & 35 & 3,54 & 93 & 1 & 5 & 4 & 0,97 & 0,43 & 0,44 & 0,89 \\
\hline 11 & 40 & 3,73 & 98 & 2 & 5 & 3 & 0,72 & 0,18 & 0,25 & 0,58 \\
\hline 12 & 42 & 3,62 & 95 & 2 & 5 & 3 & 0,92 & 0,37 & 0,40 & 0,83 \\
\hline 13 & 42 & 3,38 & 89 & 2 & 5 & 3 & 0,58 & 0,04 & 0,07 & 0,27 \\
\hline 14 & 42 & 4,02 & 106 & 2 & 5 & 3 & 0,77 & 0,23 & 0,30 & 0,65 \\
\hline 15 & 35 & 4,06 & 107 & 1 & 5 & 4 & 1,15 & 0,60 & 0,52 & 1,05 \\
\hline 16 & 41 & 3,93 & 104 & 2 & 5 & 3 & 0,85 & 0,30 & 0,35 & 0,75 \\
\hline 17 & 36 & 3,50 & 92 & 2 & 5 & 3 & 0,87 & 0,33 & 0,38 & 0,78 \\
\hline 18 & 41 & 3,78 & 100 & 3 & 5 & 2 & 0,53 & $-0,02^{*}$ & $-0,04^{*}$ & 0,00 \\
\hline 19 & 46 & 4,15 & 110 & 2 & 5 & 3 & 0,57 & 0,03 & 0,05 & 0,24 \\
\hline 20 & 38 & 4,00 & 106 & 3 & 5 & 2 & 0,54 & $-0,01^{*}$ & $-0,02^{*}$ & - \\
\hline 21 & 39 & 3,97 & 105 & 2 & 5 & 3 & 1,04 & 0,50 & 0,48 & 0,96 \\
\hline 22 & 40 & 4,00 & 106 & 2 & 5 & 3 & 0,87 & 0,32 & 0,37 & 0,77 \\
\hline 23 & 36 & 4,39 & 116 & 3 & 5 & 2 & 0,50 & $-0,05^{*}$ & $-0,10^{*}$ & - \\
\hline 24 & 37 & 3,92 & 103 & 2 & 5 & 3 & 0,78 & 0,24 & 0,31 & 0,67 \\
\hline 25 & 36 & 3,56 & 94 & 2 & 5 & 3 & 0,75 & 0,21 & 0,28 & 0,62 \\
\hline 26 & 35 & 3,69 & 97 & 1 & 5 & 4 & 0,95 & 0,41 & 0,43 & 0,87 \\
\hline 27 & 41 & 3,71 & 98 & 1 & 5 & 4 & 1,42 & 0,87 & 0,61 & 1,27 \\
\hline 28 & 41 & 3,88 & 102 & 2 & 5 & 3 & 0,82 & 0,27 & 0,33 & 0,71 \\
\hline 29 & 38 & 3,95 & 104 & 2 & 5 & 3 & 0,54 & $-0,01^{*}$ & $-0,02^{\circ}$ & - \\
\hline 30 & 39 & 3,95 & 104 & 2 & 5 & 3 & 0,89 & 0,35 & 0,39 & 0,81 \\
\hline 31 & 29 & 3,62 & 96 & 2 & 5 & 3 & 0,75 & 0,20 & 0,27 & 0,61 \\
\hline 32 & 42 & 3,62 & 95 & I & 5 & 4 & 1,06 & 0,51 & 0,48 & 0,97 \\
\hline 33 & 41 & 3,71 & 98 & 1 & 5 & 4 & 0,88 & 0,33 & 0,38 & 0,78 \\
\hline 34 & 42 & 3,79 & 100 & 3 & 5 & 2 & 0,60 & 0,05 & 0,08 & 0,30 \\
\hline 35 & 42 & 3,95 & 104 & 2 & 5 & 3 & 1,00 & 0,46 & 0,46 & 0,92 \\
\hline 36 & 37 & 3,54 & 93 & 2 & 5 & 3 & 0,84 & 0,29 & 0,35 & 0,73 \\
\hline 37 & 36 & 3,94 & 104 & 2 & 5 & 3 & 0,72 & 0,18 & 0,25 & 0,58 \\
\hline 38 & 43 & 3,35 & 88 & 2 & 5 & 3 & 0,79 & 0,24 & 0,30 & 0,67 \\
\hline 39 & 33 & 3,76 & 99 & 2 & 5 & 3 & 0,57 & 0,03 & 0,05 & 0,24 \\
\hline 40 & 44 & 3,89 & 103 & 3 & 5 & 2 & 0,47 & $-0,08^{*}$ & $-0,17^{*}$ & - \\
\hline 41 & 42 & 3,76 & 99 & 1 & 5 & 4 & 1,37 & 0,82 & 0,60 & 1,23 \\
\hline 42 & 42 & 3,24 & 85 & 1 & 5 & 4 & 1,26 & 0,72 & 0,57 & 1,15 \\
\hline 43 & 43 & 3,65 & 96 & 2 & 5 & 3 & 0,58 & 0,03 & 0,05 & 0,24 \\
\hline 44 & 39 & 4,08 & 108 & 2 & 5 & 3 & 0,93 & 0,38 & 0,41 & 0,84 \\
\hline 45 & 45 & 3,62 & 96 & 1 & 5 & 4 & 0,91 & 0,37 & 0,41 & 0,83 \\
\hline MEDIA F $3: 2[4]$ & - & 3,78 & 100 & - & - & - & 0,81 & 0,27 & 0,33 & 0,71 \\
\hline Cristalina & 35 & 4,14 & 99 & 2 & 5 & 3 & 0,71 & - & $\overline{-}$ & 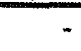 \\
\hline IAC- 8 & 42 & 3,90 & 93 & 2 & 5 & 3 & 0,46 & - & - & - \\
\hline EMGOPA-301 & 30 & 4,40 & 105 & 3 & 5 & 2 & 0,50 & - & - & - \\
\hline SS-1 & 43 & 4,35 & 104 & 2 & 5 & 3 & 0,53 & - & - & - \\
\hline MEDIA TESTEM. & - & 4,20 & 100 & - & - & - & - & - & - & - \\
\hline
\end{tabular}

'Para identificar os cruzamentos que deram origem à estas populações $\mathrm{F}_{3: 2 \text { [4] }}$, consultar o Apêndice 6. "Foi considerado = 0 no cálculo da média. ${ }^{2}$ Média aritmética de todos os valores individuais $(\mathrm{i}=1,2, \ldots, \mathrm{N})$. Variância ponderada , conforme a freqüência de plantas $(n=1,2, \ldots, 12)$ e respectiva variância por repetição, com as quatro repetições. 
131

Tabela 20 PG: Produtividade de Grãos (g/planta) da geração $\mathbf{F}_{2[4]}$ de 45 cruzamentos quádruplos, e de 4 testemunhas. Número de plantas $(N)$, média $\left(\vec{Y}_{i}\right)$, porcentagem em relação à média (\%), valores minimos (Min.) e máximos (Max), amplitude (Max. - Min.), variància fenotípica entre plantas $\left(S^{2}\right)$, variância genotípica $\left(S^{2} g\right)$, herdabilidade no sentido amplo $\left(\mathrm{h}_{\mathrm{a}}^{2}\right)$ e relação entre os coeficientes de variação genética e ambiental (b). Soja, Piracicaba - SP (semeadura 04/12/1992). VARIÂNCIA AMBIENTAL $\left(\mathrm{S}_{\mathrm{a}}^{2}\right)=661,84$.

\begin{tabular}{|c|c|c|c|c|c|c|c|c|c|c|}
\hline $\begin{array}{c}\text { POPULAÇÃO } \\
F_{2[4]}\end{array}$ & $\bar{N}$ & $\overline{\bar{Y}}_{i}^{\mathrm{a}}$ & $(\%)$ & Min. & Max. & Ampl. & $\mathrm{S}_{\mathrm{d}}^{2}$ & $\overline{\mathrm{S}_{\mathrm{g}}^{2}}$ & $\overline{\mathrm{h}^{2}}$ & $\bar{b}$ \\
\hline 1 & 34 & 105,38 & 95 & 37,65 & 220,88 & 183,23 & 1872,20 & 1210,36 & 0,65 & 1,35 \\
\hline 2 & 42 & 117,64 & 106 & 17,91 & 217,43 & 199,52 & 1936,04 & 1274,20 & 0,66 & 1,39 \\
\hline 3 & 35 & 114,01 & 103 & 31,69 & 201,42 & 169,73 & 2469,20 & 1807,36 & 0,73 & 1,65 \\
\hline 4 & 36 & 113,08 & 102 & 33,27 & 190,68 & 157,41 & 1528,92 & 867,08 & 0,57 & 1,14 \\
\hline 5 & 38 & 114,12 & 103 & 34,00 & 223,07 & 189,07 & 2032,63 & 1370,79 & 0,67 & 1,44 \\
\hline 6 & 41 & 111,97 & 101 & 27,78 & 222,74 & 194,96 & 2590,28 & 1928,44 & 0,74 & 1,71 \\
\hline 7 & 30 & 98,37 & 89 & 35,55 & 184,32 & 148,77 & 2014,31 & 1352,47 & 0,67 & 1,43 \\
\hline 8 & 37 & 118,19 & 106 & 42,27 & 196,10 & 153,83 & 1637,73 & 975,89 & 0,60 & 1,21 \\
\hline 9 & 24 & 85,37 & 77 & 24,72 & 202,83 & 178,11 & 1696,79 & 1034,95 & 0,61 & 1,25 \\
\hline 10 & 42 & 118,10 & 106 & 33,10 & 219,89 & 186,79 & 1589,92 & 928,08 & 0,58 & 1,18 \\
\hline 11 & 46 & 101,08 & 91 & 23,76 & 213,74 & 189,98 & 2175,10 & 1513,26 & 0,70 & 1,51 \\
\hline 12 & 38 & 113,20 & 102 & 31,24 & 228,93 & 197,69 & 1890,08 & 1228,24 & 0,65 & 1,36 \\
\hline 13 & 36 & 105,42 & 95 & 51,61 & 256,52 & 204,91 & 2587,49 & 1925,65 & 0,74 & 1,71 \\
\hline 14 & 24 & 105,55 & 95 & 29,26 & 216,29 & 187,03 & 1417,84 & 756,00 & 0,53 & 1,07 \\
\hline 15 & 41 & 109,38 & 98 & 23,28 & 205,56 & 182,28 & 1811,66 & 1149,82 & 0,63 & 1,32 \\
\hline 16 & 37 & 132,08 & 119 & 34,59 & 210,22 & 175,63 & 1462,78 & 800,94 & 0,55 & 1,10 \\
\hline 17 & 25 & 98,35 & 88 & 21,94 & 217,56 & 195,62 & 2414,54 & 1752,70 & 0,73 & 1,63 \\
\hline 18 & 39 & 107,26 & 97 & 39,72 & 216,57 & 176,85 & 1485,63 & 823,79 & 0,55 & 1,12 \\
\hline 19 & 39 & 137,63 & 124 & 57,03 & 246,57 & 189,54 & 1717,48 & 1055,64 & 0,61 & 1,26 \\
\hline 20 & 43 & 118,51 & 107 & 30,86 & 198,45 & 167,59 & 1787,30 & 1125,46 & 0,63 & 1,30 \\
\hline 21 & 37 & 147,31 & 133 & 48,75 & 231,85 & 183,10 & 1568,70 & 906,86 & 0,58 & 1,17 \\
\hline 22 & 42 & 133,91 & 120 & 20,69 & 224,69 & 204,00 & 2211,96 & 1550,12 & 0,70 & 1,53 \\
\hline 23 & 40 & 140,38 & 126 & 29,57 & 239,01 & 209,44 & 3225,54 & 2563,70 & 0,79 & 1,97 \\
\hline 24 & 43 & 110,45 & 99 & 26,77 & 177,09 & 150,32 & 1320,05 & 658,21 & 0,50 & 1,00 \\
\hline 25 & 34 & 102,99 & 93 & 32,78 & 204,67 & 171,89 & 1523,75 & 861,91 & 0,57 & 1,14 \\
\hline 26 & 44 & 116,81 & 105 & 33,58 & 218,21 & 184,63 & 1701,64 & 1039,80 & 0,61 & 1,25 \\
\hline 27 & 41 & 111,31 & 100 & 22,01 & 215,01 & 193,00 & 2423,22 & 1761,38 & 0,73 & 1,63 \\
\hline 28 & 43 & 94,80 & 85 & 27,53 & 197,72 & 170,19 & 2322,07 & 1660,23 & 0,71 & 1,58 \\
\hline 29 & 40 & 115,45 & 104 & 42,57 & 178,85 & 136,28 & 1420,32 & 758,48 & 0,53 & 1,07 \\
\hline 30 & 43 & 101,49 & 91 & 11,81 & 205,55 & 193,74 & 1677,48 & 1015,64 & 0,61 & 1,24 \\
\hline 31 & 38 & 116,31 & 105 & 53,80 & 186,56 & 132,76 & 1351,85 & 690,01 & 0,51 & 1,02 \\
\hline 32 & 43 & 99,63 & 90 & 23,49 & 186,22 & 162,73 & 1408,87 & 747,03 & 0,53 & 1,06 \\
\hline 33 & 38 & 110,01 & 99 & 26,17 & 200,10 & 173,93 & 2304,20 & 1642,36 & 0,71 & 1,58 \\
\hline 34 & 42 & 109,02 & 98 & 21,30 & 201,18 & 179,88 & 1627,56 & 965,72 & 0,59 & 1,21 \\
\hline 35 & 45 & 107,33 & 97 & 15,38 & 251,14 & 235,76 & 2830,00 & 2168,16 & 0,77 & 1,81 \\
\hline 36 & 45 & 117,09 & 105 & 18,30 & 196,85 & 178,55 & 1892,12 & 1230,28 & 0,65 & 1,36 \\
\hline 37 & 39 & 104,56 & 94 & 27,41 & 203,66 & 176,25 & 2104,25 & 1442,41 & 0,69 & 1,48 \\
\hline 38 & 40 & 107,46 & 97 & 23,16 & 216,24 & 193,08 & 1296,34 & 634,50 & 0,49 & 0,98 \\
\hline 39 & 41 & 115,38 & 104 & 45,24 & 216,75 & 171,51 & 1919,19 & 1257,35 & 0,66 & 1,38 \\
\hline 40 & 42 & 118,68 & 107 & 46,40 & 208,47 & 162,07 & 1848,28 & 1186,44 & 0,64 & 1,34 \\
\hline 41 & 41 & 105,04 & 95 & 18,60 & 272,42 & 253,82 & 2053,29 & 1391,45 & 0,68 & 1,45 \\
\hline 42 & 43 & 99,12 & 89 & 20,92 & 174,96 & 154,04 & 1294,81 & 632,97 & 0,49 & 0,98 \\
\hline 43 & 36 & 94,04 & 85 & 26,03 & 206,44 & 180,41 & 1777,01 & 1115,17 & 0,63 & 1,30 \\
\hline 44 & 43 & 97,30 & 88 & 31,33 & 178,06 & 146,73 & 1330,14 & 668,30 & 0,50 & 1,00 \\
\hline 45 & 42 & 100,67 & 91 & 40,39 & 168,65 & 128,26 & 802,99 & 141,15 & 0,18 & 0,46 \\
\hline MÉDIA F $_{2[4]}$ & - & 111,14 & 100 & - & - & - & 1852,30 & 1190,46 & 0,64 & 1,34 \\
\hline Cristalina & 40 & 141,12 & 107 & 99,37 & 187,64 & 88,27 & 689,01 & - & 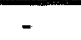 & - \\
\hline IAC-8 & 21 & 128,14 & 97 & 77,12 & 178,32 & 101,20 & 843,30 & - & - & - \\
\hline EMGOPA-301 & 21 & 138,72 & 105 & 79,86 & 202,51 & 122,65 & 905,12 & - & - & - \\
\hline SS-I & 31 & 119,08 & 90 & 81,71 & 167,65 & 85,94 & 364,83 & - & - & - \\
\hline MEDIA TESTEM & - & 131,77 & 100 & - & - & - & - & - & - & - \\
\hline
\end{tabular}

T'Para identificar os cruzamentos que deram origem à estas populações $F_{2[4]}$, consultar o Apêndice 6 .

${ }^{2}$ Média aritmética de todos os valores individuais $(\mathrm{i}=1,2, \ldots, \mathrm{N})$. VVariância ponderada, conforme a freqüência de plantas $(\mathrm{n}=1,2, \ldots, 12)$ e respectiva variância por repetição, com as quatro repetições. 
Tabela 21 PG: Produtividade de Grãos (g/planta) da geração $\mathbf{F}_{3: 2[4]}$ de 45 cruzamentos quádruplos, e de 4 testemunhas. Número de plantas $(\mathrm{N})$, média $\left(\bar{Y}_{i}\right)$, porcentagem em relação à média $(\%)$, valores mínimos $($ Mín. $)$ e máximos (Max), amplitude (Max. - Min.), variância fenotípica entre plantas $\left(\mathrm{S}_{\mathrm{d}}^{2}\right)$, variância genotípica $\left(\mathrm{S}_{\mathrm{g}}^{2}\right)$, herdabilidade no sentido amplo $\left(\mathrm{h}_{\mathrm{a}}^{2}\right)$ e relação entre os coeficientes de variaçăo genética e ambiental (b). Soja, Maracaí - SP (semeadura 02/12/1993). VARIÂNCIA AMBIENTAL $\left(\mathrm{S}_{\mathrm{a}}^{2}\right)=267,05$.

\begin{tabular}{|c|c|c|c|c|c|c|c|c|c|c|}
\hline $\begin{array}{c}\text { POPULAÇÃO } \\
\mathrm{F}_{3 \cdot 2141} \\
\end{array}$ & $\mathrm{~N}$ & $Y_{i}^{a}$ & $(\%)$ & Min. & Max. & Ampl. & $S_{d}^{26}$ & $\overline{\mathrm{S}}_{\mathrm{g}}^{2-}$ & $\bar{h}_{a}^{2-}$ & b \\
\hline 1 & 41 & 48,30 & 82 & 9,53 & 125,82 & 116,29 & 544,07 & 277,02 & 0,51 & 1,02 \\
\hline 2 & 35 & 49,19 & 84 & 7,65 & 110,36 & 102,71 & 501,97 & 234,92 & 0,47 & 0,94 \\
\hline 3 & 33 & 73,61 & 125 & 31,64 & 154,31 & 122,67 & 460,83 & 193,78 & 0,42 & 0,85 \\
\hline 4 & 38 & 53,97 & 92 & 13,82 & 102,69 & 88,87 & 424,56 & 157,51 & 0,37 & 0,77 \\
\hline 5 & 41 & 48,66 & 83 & 6,88 & 119,54 & 112,66 & 577,10 & 310,05 & 0,54 & 1,08 \\
\hline 6 & 36 & 72,36 & 123 & 13,37 & 142,69 & 129,32 & 972,27 & 705,22 & 0,73 & 1,63 \\
\hline 7 & 34 & 58,62 & 100 & 15,30 & 121,55 & 106,25 & 673,00 & 405,95 & 0,60 & 1,23 \\
\hline 8 & 37 & 63,56 & 108 & 16,43 & 119,12 & 102,69 & 490,73 & 223,68 & 0,46 & 0,92 \\
\hline 9 & 35 & 63,82 & 109 & 20,36 & 142,53 & 122,17 & 540,10 & 273,05 & 0,51 & 1,01 \\
\hline 10 & 37 & 56,86 & 97 & 13,41 & 159,87 & 146,46 & 883,64 & 616,59 & 0,70 & 1,52 \\
\hline 11 & 40 & 58,60 & 100 & 8,40 & 115,52 & 107,12 & 491,97 & 224,92 & 0,46 & 0,92 \\
\hline 12 & 42 & 54,01 & 92 & 13,38 & 100,62 & 87,24 & 814,62 & 547,57 & 0,67 & 1,43 \\
\hline 13 & 42 & 52,45 & 89 & 11,27 & 106,55 & 95,28 & 498,52 & 231,47 & 0,46 & 0,93 \\
\hline 14 & 42 & 55,76 & 95 & 11,79 & 106,65 & 94,86 & 506,99 & 239,94 & 0,47 & 0,95 \\
\hline 15 & 35 & 61,19 & 104 & 17,45 & 129,40 & 111,95 & 697,92 & 430,87 & 0,62 & 1,27 \\
\hline 16 & 41 & 57,53 & 98 & 11,24 & 117,00 & 105,76 & 566,77 & 299,72 & 0,53 & 1,06 \\
\hline 17 & 36 & 40,56 & 69 & 8,33 & 94,66 & 86,33 & 663,44 & 396,39 & 0,60 & 1,22 \\
\hline 18 & 41 & 56,17 & 96 & 10,90 & 122,82 & 111,92 & 480,06 & 213,01 & 0,44 & 0,89 \\
\hline 19 & 46 & 66,49 & 113 & 17,98 & 123,15 & 105,17 & 465,01 & 197,96 & 0,43 & 0,86 \\
\hline 20 & 38 & 64,33 & 109 & 23,93 & 104,57 & 80,64 & 351,95 & 84,90 & 0,24 & 0,56 \\
\hline 21 & 39 & 73,89 & 126 & 12,10 & 135,88 & 123,78 & 1056,03 & 788,98 & 0,75 & 1,72 \\
\hline 22 & 40 & 66,95 & 114 & 19,49 & 128,75 & 109,26 & 774,69 & 507,64 & 0,66 & 1,38 \\
\hline 23 & 36 & 73,77 & 126 & 13,40 & 141,90 & 128,50 & 655,70 & 388,65 & 0,59 & 1,21 \\
\hline 24 & 37 & 63,87 & 109 & 23,17 & 140,00 & 116,83 & 379,92 & 112,87 & 0,30 & 0,65 \\
\hline 25 & 36 & 45,65 & 78 & 8,06 & 74,47 & 66,41 & 226,31 & $-40,74^{*}$ & $-0,18^{\circ}$ & $\therefore$ \\
\hline 26 & 35 & 48,56 & 83 & 10,40 & 112,00 & 101,60 & 476,08 & 209,03 & 0,44 & 0,88 \\
\hline 27 & 41 & 59,67 & 102 & 8,54 & 122,00 & 113,46 & 650,65 & 383,60 & 0,59 & 1,20 \\
\hline 28 & 41 & 59,36 & 101 & 16,03 & 120,10 & 104,07 & 541,46 & 274,41 & $0,5]$ & 1,01 \\
\hline 29 & 38 & 68,79 & 117 & 25,89 & 124,23 & 98,34 & 532,66 & 265,61 & 0,50 & 1,00 \\
\hline 30 & 39 & 56,92 & 97 & 20,40 & 116,66 & 96,26 & 463,48 & 196,43 & 0,42 & 0,86 \\
\hline 31 & 31 & 50,39 & 86 & 17,40 & 97,76 & 80,36 & 233,45 & $-33,60^{\circ}$ & $-0,14^{*}$ & $=*$ \\
\hline 32 & 42 & 56,98 & 97 & 9,27 & 159,29 & 150,02 & 757,84 & 490,79 & 0,65 & 1,36 \\
\hline 33 & 41 & 57,74 & 98 & 17,34 & 101,04 & 83,70 & 436,83 & 169,78 & 0,39 & 0,80 \\
\hline 34 & 43 & 70,57 & 120 & 30,68 & 125,87 & 95,19 & 498,93 & 231,88 & 0,46 & 0,93 \\
\hline 35 & 42 & 60,97 & 104 & 15,18 & 124,10 & 108,92 & 531,06 & 264,01 & 0,50 & 0,99 \\
\hline 36 & 37 & 60,08 & 102 & 10,21 & 148,41 & 138,20 & 1027,82 & 760,77 & 0,74 & 1,69 \\
\hline 37 & 36 & 54,62 & 93 & 8,16 & 134,09 & 125,93 & 700,92 & 433,87 & 0,62 & 1,27 \\
\hline 38 & 43 & 45,41 & 77 & 14,55 & 113,55 & 99,00 & 258,66 & $-8,39^{*}$ & $-0,03^{\circ}$ & $=$ \\
\hline 39 & 33 & 62,21 & 106 & 10,37 & 118,23 & 107,86 & 380,08 & 113,03 & 0,30 & 0,65 \\
\hline 40 & 44 & 55,28 & 94 & 21,80 & 97,73 & 75,93 & 260,49 & $-6,56^{*}$ & $-0,03^{*}$ & $\therefore$ \\
\hline 41 & 43 & 70,29 & 120 & 21,65 & 134,14 & 112,49 & 893,41 & 626,36 & 0,70 & 1,53 \\
\hline 42 & 42 & 55,50 & 94 & 18,68 & 134,57 & 115,89 & 806,73 & 539,68 & 0,67 & 1,42 \\
\hline 43 & 43 & 53,04 & 90 & 11,42 & 130,18 & 118,76 & 487,21 & 220,16 & 0,45 & 0,91 \\
\hline 44 & 39 & 59,86 & 102 & 11,59 & 108,93 & 97,34 & 497,87 & 230,82 & 0,46 & 0,93 \\
\hline 45 & 45 & 57,99 & 99 & 10,88 & 107,66 & 96,78 & 608,87 & 341,82 & 0,56 & 1,13 \\
\hline MEDIA F $_{3: 24\}}$ & - & 58,76 & 100 & - & - & - & 572,06 & 306,99 & 0,54 & 1,07 \\
\hline Cristalina & 28 & 79,25 & 109 & 51,35 & 123,00 & 71,65 & 271,40 & - & - & - \\
\hline IAC-8 & 31 & 66,00 & 90 & 31,72 & 124,50 & 92,78 & 257,39 & - & - & - \\
\hline EMGOPA-301 & 24 & 80,96 & 111 & 47,41 & 128,33 & 80,92 & 446,42 & - & - & - \\
\hline SS-I & 36 & 65,83 & 90 & 42,34 & 96,38 & 54,04 & 163,10 & - & - & - \\
\hline
\end{tabular}

MEDIA TESTEM - $\quad 73,01 \quad 100$

'Para identificar os cruzamentos que deram origem à estas populações $\mathrm{F}_{3: 2[4]}$, consultar o Apêndice 6 . Foi considerado = 0 no cálculo da média. ${ }^{\mathrm{a}}$ Média aritmética de todos os valores individuais $(\mathrm{i}=1,2, \ldots, \mathrm{N})$. bariância ponderada, conforme a frequêencia de plantas $(n=1,2, \ldots, 12)$ e respectiva variância por repetição, com as quatro repetições. 
Tabela 22 Resumos das análises de variância, com os quadrados médios, niveis de significância, médias e coeficientes de variação do experimento de 20 parentais e do experimento com 45 populações $F_{2[4]}$ de cruzamentos quádruplos e 4 testemunhas. Soja. Piracicaba-SP (semeadura 04/12/92).

\begin{tabular}{lccccccc}
\hline \multicolumn{10}{c}{ PARENTAIS $^{1}$} \\
\hline & & \multicolumn{7}{c}{ Q. M. dos Caracteres } \\
\cline { 2 - 8 } F. V. & G.L. & NDF (dias) & APF (cm) & NDM (dias) & APM (cm) & VA (nota) & PG \\
\hline Genótipos & 19 & $131,97^{* *}$ & $250,99^{* *}$ & $228,08^{* *}$ & $248,04^{*}$ & $0,21^{\text {n.s. }}$ & $1241,20^{*}$ \\
Repetições & 1 & $0,18^{\text {ns. }}$ & $37,47^{\text {n.* }}$ & $146,94^{*}$ & $184,26^{\text {n. }}$ & $0,17^{\text {n.s. }}$ & $6,70^{\text {n.s. }}$ \\
Resíduo & 19 & 3,70 & 48,85 & 20,61 & 107,60 & 0,13 & 460,34 \\
\hline Média & - & 68,11 & 65,44 & 145,73 & 85,71 & 4,55 & 112,11 \\
C.V. & $(\%)$ & 2,82 & 10,68 & 3,12 & 12,10 & 7,95 & 19,14 \\
\hline
\end{tabular}

\section{POPULAÇÕES $F_{2[4]}+$ TESTEMUNHAS}

\begin{tabular}{lccccccc}
\hline & & \multicolumn{7}{c}{ Q.M. dos Caracteres } \\
\cline { 3 - 8 } F. V. & G.L. & NDF (dias) & APF (cm) & NDM & APM $(\mathrm{cm})$ & VA (nota) & PG \\
\hline Genótipos & 48 & $165,25^{* *}$ & $276,48^{* *}$ & $368,23^{* *}$ & $294,61^{* *}$ & $0,45^{* *}$ & $638,84^{* *}$ \\
Testemunhas & 3 & $185,64^{* *}$ & $345,24^{* *}$ & $479,69^{* *}$ & $296,68^{* *}$ & $0,51^{*}$ & $378,69^{\text {n.s. }}$ \\
Populações & 44 & $166,53^{* *}$ & $276,34^{* *}$ & $367,81^{* *}$ & $297,02^{* *}$ & $0,43^{* *}$ & $556,15^{* *}$ \\
Test vs Popul. & 1 & $47,68^{\text {ns. }}$ & $76,47^{\text {n.s. }}$ & $52,24^{\text {n.s. }}$ & $182,29^{\text {n.s. }}$ & $1,07^{* *}$ & $5057,27^{* *}$ \\
Repetições & 3 & $12,71^{\text {n.s }}$ & $256,72^{* *}$ & $105,82^{*}$ & $110,46^{\text {ns. }}$ & $1,03^{* *}$ & $136,86^{\text {n.s. }}$ \\
Resíduo & 144 & 12,53 & 38,70 & 39,32 & 53,27 & 0,15 & 287,06 \\
\hline Média Test. & - & 64,21 & 64,72 & 141,43 & 83,67 & 4,16 & 130,13 \\
Média Popul. & - & 66,01 & 67,00 & 143,31 & 87,20 & 3,89 & 111,58 \\
Média Geral & - & 65,86 & 66,81 & 143,16 & 86,91 & 3,92 & 113,10 \\
C.V. & $(\%)$ & 5,37 & 9,31 & 4,38 & 8,40 & 9,75 & 14,98 \\
\hline
\end{tabular}

${ }^{1}$ Para identificar os caracteres, parentais e testemunhas, consultar o Apêndice 1.

${ }^{2}$ Os cruzamentos que deram origem à estas populações $\mathrm{F}_{2[4]}$ encontram-se descritos no Apêndice 6 .

* $\mathrm{e}^{* *}$ Significativo ao nível de $5 \%$ e $1 \%$ de probabilidade pelo teste "F", respectivamente.

ns. Não significativo. 
Tabela 23 Resumos das análises de variância, com os quadrados médios, níveis de significância, médias e coeficientes de variação do experimento de 20 parentais e do experimento de 45 populações $\mathrm{F}_{3: 2[4]}$ de cruzamentos quádruplos e 4 testemunhas. Soja. Maracaí-SP (semeadura em $02 / 12 / 92$ ).

\section{PARENTAIS ${ }^{1}$}

\begin{tabular}{lccccccc}
\hline & & \multicolumn{7}{c}{ Q.M. dos Caracteres } \\
\cline { 3 - 8 } F. V. & G.L. & NDF (dias) & APF (cm) & NDM (dias) & APM (cm) & VA (nota) PG (g/planta) \\
\hline Genótipos & 19 & $97,22^{* *}$ & $210,72^{* *}$ & $189,29^{* *}$ & $295,31^{* *}$ & $0,33^{*}$ & $475,32^{*}$ \\
Repetições & 1 & $0,06^{\text {n. }}$ & $15,36^{\text {n. }}$ & $83,81^{* *}$ & $31,12^{\text {ns. }}$ & $0,70^{*}$ & $842,83^{*}$ \\
Resíduo & 19 & 0,79 & 32,64 & 10,60 & 25,26 & 0,15 & 190,20 \\
\hline Média & - & 67,38 & 63,26 & 135,26 & 77,58 & 4,24 & 67,09 \\
C.V. & $(\%)$ & 1,32 & 9,03 & 2,41 & 6,48 & 9,00 & 20,56 \\
\hline
\end{tabular}

\section{POPULAÇÕES $F_{3: 2[4]}+$ TESTEMUNHAS}

\begin{tabular}{lccccccc}
\hline & & \multicolumn{7}{c}{ Q. M. dos Caracteres } \\
\cline { 3 - 7 } F. V. & G.L. & NDF (dias) & APF $(\mathrm{cm})$ & NDM (dias) & APM $(\mathrm{cm})$ & VA (nota) & PG (g/planta) \\
\hline Genótipos & 48 & $78,41^{* *}$ & $267,51^{* *}$ & $276,00^{* *}$ & $457,51^{* *}$ & $0,25^{* *}$ & $332,10^{* *}$ \\
Testemunhas & 3 & $108,19^{* *}$ & $291,71^{* *}$ & $495,50^{* *}$ & $247,03^{* *}$ & $0,22^{\text {n.s. }}$ & $365,10^{\text {n.s. }}$ \\
Populações & 44 & $78,24^{* *}$ & $271,91^{* *}$ & $265,35^{* *}$ & $476,75^{* *}$ & $0,20^{* *}$ & $260,91^{* *}$ \\
Test vs & 1 & $22,48^{\text {n.s. }}$ & $0,70^{\text {n.s. }}$ & $130,31^{\text {n.s. }}$ & $307,85^{* *}$ & $2,58^{* *}$ & $3232,01^{* *}$ \\
Repetições & 3 & $3,74^{\text {n. }}$ & $48,69^{\text {n.s. }}$ & $137,37^{*}$ & $100,06^{\text {n.s. }}$ & $0,01^{\text {n.s. }}$ & $1683,31^{* *}$ \\
Resíduo & 144 & 8,98 & 28,43 & 40,36 & 50,75 & 0,11 & 146,82 \\
\hline Média Test. & - & 65,14 & 60,19 & 130,35 & 69,52 & 4,20 & 73,84 \\
Média Pop. & - & 66,38 & 60,41 & 133,33 & 74,10 & 3,79 & 59,01 \\
Média Geral & - & 66,28 & 60,40 & 133,09 & 73,75 & 3,82 & 60,25 \\
C.V. & $(\%)$ & 4,52 & 8,83 & 4,77 & 9,66 & 8,65 & 20,11 \\
\hline
\end{tabular}

${ }^{1}$ Para identificar os caracteres, parentais e testemunhas consultar o Apêndice 1.

${ }^{2}$ Para identificar os cruzamentos que deram origem à estas populações $F_{3: 2[4]}$, consultar o Apêndice 6 .

* e ** Significativo ao nivel de $5 \%$ e $1 \%$ de probabilidade pelo teste "F", respectivamente.

ns. Não significativo. 
Tabela 24 Resumos das análises de variància conjunta em dois ambientes, com os quadrados médios, niveis de significància, médias e coeficientes de variação do experimento de 20 parentais e de 4 testemunhas. Soja. Piracicaba - SP (semeadura 04/12/92) e Maracaí - SP (semeadura 02/12/93).

PARENTAIS $^{1}$

\begin{tabular}{lccccccc}
\hline & & \multicolumn{7}{c}{ Q.M.dos Caracteres } \\
\cline { 3 - 7 } F. V. & G.L. & NDF (dias) & APF $(\mathrm{cm})$ & NDM (dias) & APM $(\mathrm{cm})$ & VA (nota) & PG (g/planta) \\
\hline Ambientes & 1 & $10,72^{\text {n.s. }}$ & $95,05^{\text {n. }}$ & $2191,37^{*}$ & $1323,84^{* *}$ & $1,91^{\text {n.s. }}$ & $40527,09^{* *}$ \\
Genótipos & 19 & $222,93^{* *}$ & $409,59^{* *}$ & $373,79^{* *}$ & $483,82^{* *}$ & $0,25^{\text {n.s. }}$ & $1102,51^{* *}$ \\
Gx A & 19 & $6,25^{* *}$ & $52,12^{\text {n.s. }}$ & $43,58^{* *}$ & $59,53^{\text {n.s. }}$ & $0,29^{*}$ & $614,02^{*}$ \\
Rep(Amb.) & 2 & $0,12^{\text {n.s. }}$ & $26,41^{\text {n.s. }}$ & $115,38^{* *}$ & $107,69^{\text {n.s. }}$ & $0,44^{*}$ & $424,77^{\text {n.s. }}$ \\
Resíduo & 38 & 2,24 & 40,74 & 15,60 & 66,43 & 0,14 & 325,27 \\
\hline Média & - & 67,75 & 64,35 & 140,49 & 81,64 & 4,40 & 89,60 \\
C.V. & $(\%)$ & 2,21 & 9,92 & 2,81 & 9,98 & 8,46 & 20,13 \\
\hline
\end{tabular}

TESTEMUNHAS $^{1}$

\begin{tabular}{lccccccc}
\hline & & \multicolumn{7}{c}{ Q. M.dos Caracteres } \\
\cline { 3 - 8 } F. V. & G.L. & NDF (dias) & APF $(\mathrm{cm})$ & NDM (dias) & APM $(\mathrm{cm})$ & VA & PG (g/planta) \\
\hline Ambientes & 1 & $7,00^{\text {n.s. }}$ & $164,26^{\text {n.s }}$ & $981,36^{* *}$ & $1602,32^{* *}$ & $0,01^{\text {n.s. }}$ & $25352,24^{* *}$ \\
Genótipos & 3 & $287,66^{* *}$ & $615,40^{* *}$ & $962,60^{* *}$ & $512,07^{* *}$ & $0,60^{\text {n.s. }}$ & $732,66^{*}$ \\
G x A & 3 & $6,17^{\text {n.s. }}$ & $21,54^{\text {n.s. }}$ & $12,60^{* *}$ & $31,65^{\text {n.s. }}$ & $0,13^{\text {n.s. }}$ & $11,13^{\text {n.s. }}$ \\
Rep(Amb. & 6 & $1,07^{\text {n. }}$ & $37,89^{* *}$ & $16,25^{\text {n.s. }}$ & $44,13^{*}$ & $0,12^{\text {n.s. }}$ & $427,21^{\text {n. }}$ \\
Resíduo & 18 & 3,37 & 8,92 & 8,51 & 13,74 & 0,20 & 181,89 \\
\hline Média & - & 64,67 & 62,45 & 135,89 & 76,60 & 4,18 & 101,99 \\
C.V. & $(\%)$ & 2,84 & 4,78 & 2,15 & 4,84 & 10,62 & 13,22 \\
\hline
\end{tabular}

${ }^{1}$ Para identificar os caracteres, parentais e testemunhas consultar o Apêndice 1.

* e ** Significativo ao nível de $5 \%$ e $1 \%$ de probabilidade pelo teste "F", respectivamente.

ns. Não significativo. 
Tabela 25 Médias e classificações de seis caracteres ${ }^{1}$ para 20 parentais, utilizados nos cruzamentos quádruplos de soja, em Piracicaba - SP (sem. 04/12/92) e Maracai - SP (sem. 02/12/93).

\begin{tabular}{|c|c|c|c|c|c|c|}
\hline \multirow[b]{2}{*}{ GENÖTIPOS } & \multicolumn{6}{|c|}{$\overrightarrow{M E}$ DIAS DOS CARACTERES ${ }^{23}$} \\
\hline & $\begin{array}{l}\text { NDF } \\
\text { dias }\end{array}$ & $\begin{array}{l}\mathrm{APF} \\
\mathrm{cm}\end{array}$ & $\begin{array}{l}\text { NDM } \\
\text { dias }\end{array}$ & $\begin{array}{c}\mathrm{APM} \\
\mathrm{cm}\end{array}$ & $\begin{array}{l}\text { VA } \\
\text { nota }\end{array}$ & $\begin{array}{c}\text { PG } \\
\text { g/planta }\end{array}$ \\
\hline & \multicolumn{6}{|c|}{ PIRACICABA - 1992/93 } \\
\hline Cristalina & $68 \mathrm{~d}$ & $58,78 \mathrm{~b}$ & $155 \mathrm{a}$ & $76,80 \mathrm{a}$ & $4,28 \mathrm{a}$ & $155,57 \mathrm{a}$ \\
\hline EMGOPA-301 & $73 \mathrm{c}$ & $77,75 \mathrm{a}$ & $157 \mathrm{a}$ & $101,21 \mathrm{a}$ & $5,00 \mathrm{a}$ & $139,18 \mathrm{a}$ \\
\hline IAC-9 & $70 \mathrm{c}$ & $72,95 \mathrm{a}$ & $147 \mathrm{a}$ & 83,88 a & $4,72 \mathrm{a}$ & $135,34 \mathrm{a}$ \\
\hline Tropical & $79 \mathrm{~b}$ & $90,00 \mathrm{a}$ & $154 \mathrm{a}$ & $105,88 \mathrm{a}$ & $4,88 \mathrm{a}$ & $130,47 \mathrm{a}$ \\
\hline GO79-1039 & $78 \mathrm{~b}$ & $81,70 \mathrm{a}$ & 159 a & $97,10 \mathrm{a}$ & $4,90 \mathrm{a}$ & $130,26 \mathrm{a}$ \\
\hline Paranagoiana & $68 \mathrm{~d}$ & $61,03 \mathrm{~b}$ & 149 a & $88,50 \mathrm{a}$ & $4,90 \mathrm{a}$ & $127,84 \mathrm{a}$ \\
\hline IAC-11 & $63 \mathrm{e}$ & $59,05 \mathrm{~b}$ & $135 \mathrm{~b}$ & $86,50 \mathrm{a}$ & $4,90 \mathrm{a}$ & $127,28 \mathrm{a}$ \\
\hline BR79-63 & $75 \mathrm{c}$ & $75,85 \mathrm{a}$ & $157 \mathrm{a}$ & 89,75 a & $4,50 \mathrm{a}$ & $127,17 \mathrm{a}$ \\
\hline IAC-8 & $63 \mathrm{e}$ & $61,05 \mathrm{~b}$ & $141 \mathrm{~b}$ & $75,00 \mathrm{a}$ & $4,50 \mathrm{a}$ & $124,77 \mathrm{a}$ \\
\hline IAC80-3006 & $64 \mathrm{e}$ & $56,73 \mathrm{~b}$ & $135 \mathrm{~b}$ & $78,93 \mathrm{a}$ & $4,80 \mathrm{a}$ & $115,71 \mathrm{a}$ \\
\hline SS-1 & $60 \mathrm{f}$ & $47,80 \mathrm{~b}$ & $131 \mathrm{~b}$ & $75,00 \mathrm{a}$ & $4,40 \mathrm{a}$ & $115,34 \mathrm{a}$ \\
\hline IAC-5 & $58 \mathrm{f}$ & $59,52 \mathrm{~b}$ & $132 \mathrm{~b}$ & 90,83 a & $4,71 \mathrm{a}$ & $113,21 \mathrm{a}$ \\
\hline Numbaira & $68 \mathrm{~d}$ & $64,88 \mathrm{~b}$ & $143 \mathrm{~b}$ & $78,58 \mathrm{a}$ & $4,83 \mathrm{a}$ & $107,93 \mathrm{a}$ \\
\hline Santa Rosa & $59 \mathrm{f}$ & $54,27 \mathrm{~b}$ & $138 \mathrm{~b}$ & $70,88 \mathrm{a}$ & $4,46 \mathrm{a}$ & $105,23 \mathrm{a}$ \\
\hline Timbira & $83 \mathrm{a}$ & $65,10 b$ & $160 \mathrm{a}$ & $74,35 \mathrm{a}$ & $3,85 \mathrm{a}$ & 95,75 a \\
\hline IAC-4 & $60 \mathrm{f}$ & $51,13 \mathrm{~b}$ & $135 \mathrm{~b}$ & $69,54 \mathrm{a}$ & $4,08 \mathrm{a}$ & $89,05 \mathrm{a}$ \\
\hline IAC- 6 & $74 \mathrm{c}$ & $78,67 \mathrm{a}$ & $154 \mathrm{a}$ & 90,75 a & $4,58 \mathrm{a}$ & $84,85 \mathrm{a}$ \\
\hline White Biloxi & $65 \mathrm{e}$ & $58,25 \mathrm{~b}$ & $140 \mathrm{~b}$ & $82,50 \mathrm{a}$ & $4,25 \mathrm{a}$ & 83,71 a \\
\hline IAC -2 & $56 \mathrm{f}$ & $60,38 \mathrm{~b}$ & $134 \mathrm{~b}$ & $106,67 \mathrm{a}$ & $4,29 \mathrm{a}$ & $83,16 \mathrm{a}$ \\
\hline BR-11 & $80 \mathrm{~b}$ & 73,92 a & $162 \mathrm{a}$ & $91,58 \mathrm{a}$ & $4,21 \mathrm{a}$ & $50,29 a$ \\
\hline Média Geral & 68 & 65,44 & 146 & 85,71 & 4,55 & 112,11 \\
\hline \multirow[t]{2}{*}{ C.V. $(\%)$} & 2,82 & 10,68 & 3,12 & 12,10 & 7,95 & 19,14 \\
\hline & \multicolumn{6}{|c|}{ MARACAÍ - 1993/94 } \\
\hline Cristalina & $66 \mathrm{e}$ & $55,42 \mathrm{c}$ & $137 \mathrm{~b}$ & $65,67 \mathrm{~b}$ & $4,08 \mathrm{a}$ & $102,04 \mathrm{a}$ \\
\hline SS-1 & $56 \mathrm{~h}$ & $52,58 \mathrm{c}$ & $117 \mathrm{c}$ & $65,83 \mathrm{~b}$ & $5,00 \mathrm{a}$ & $87,24 \mathrm{a}$ \\
\hline EMGOPA-301 & $73 \mathrm{c}$ & $69,10 \mathrm{~b}$ & $140 \mathrm{~b}$ & $81,80 \mathrm{a}$ & $4,40 \mathrm{a}$ & $85,66 \mathrm{a}$ \\
\hline IAC-4 & $64 \mathrm{f}$ & $55,65 \mathrm{c}$ & $128 \mathrm{c}$ & $63,30 \mathrm{~b}$ & $4,82 \mathrm{a}$ & 83,03 a \\
\hline IAC-9 & $68 d$ & $62,82 \mathrm{c}$ & $140 \mathrm{~b}$ & $68,95 \mathrm{~b}$ & $4,45 \mathrm{a}$ & $81,95 \mathrm{a}$ \\
\hline White Biloxi & $64 \mathrm{f}$ & $63,29 c$ & $126 \mathrm{c}$ & 87,29 a & $3,79 \mathrm{a}$ & $81,44 \mathrm{a}$ \\
\hline IAC-11 & $64 \mathrm{f}$ & $59,50 \mathrm{c}$ & $125 \mathrm{c}$ & $75,46 \mathrm{~b}$ & $4,58 \mathrm{a}$ & $69,76 b$ \\
\hline IAC-2 & $58 \mathrm{~g}$ & $49,21 \mathrm{c}$ & $139 \mathrm{~b}$ & $102,75 \mathrm{a}$ & $4,88 \mathrm{a}$ & $67,23 \mathrm{~b}$ \\
\hline Paranagoiana & $66 \mathrm{e}$ & $55,10 \mathrm{c}$ & $128 \mathrm{c}$ & $70,07 \mathrm{~b}$ & $4,35 \mathrm{a}$ & $66,31 \mathrm{~b}$ \\
\hline IAC -5 & $58 \mathrm{~g}$ & $52,21 \mathrm{c}$ & $130 \mathrm{c}$ & $86,46 \mathrm{a}$ & $4,21 \mathrm{a}$ & $63,98 \mathrm{~b}$ \\
\hline Santa Rosa & $63 \mathrm{f}$ & $51,88 \mathrm{c}$ & $132 \mathrm{c}$ & $56,35 \mathrm{~b}$ & $3,58 \mathrm{a}$ & $63,51 \mathrm{~b}$ \\
\hline IAC-6 & $72 \mathrm{c}$ & $65,00 \mathrm{~b}$ & $138 \mathrm{~b}$ & $73,58 \mathrm{~b}$ & $4,17 \mathrm{a}$ & $63,11 b$ \\
\hline IAC-8 & $60 \mathrm{~g}$ & $67,42 b$ & $129 \mathrm{c}$ & $74,58 \mathrm{~b}$ & $3,50 \mathrm{a}$ & $59,71 \mathrm{~b}$ \\
\hline IAC80-3006 & $65 \mathrm{e}$ & $52,08 \mathrm{c}$ & $124 \mathrm{c}$ & $63,75 \mathrm{~b}$ & $4,50 \mathrm{a}$ & $58,19 \mathrm{~b}$ \\
\hline Timbira & $79 a$ & 76,54 a & $141 \mathrm{~b}$ & $83,58 \mathrm{a}$ & $4,38 \mathrm{a}$ & $56,14 \mathrm{~b}$ \\
\hline BR79-63 & $75 \mathrm{~b}$ & $75,33 \mathrm{a}$ & $151 \mathrm{a}$ & $87,08 \mathrm{a}$ & $4,08 \mathrm{a}$ & $56,04 \mathrm{~b}$ \\
\hline G079-1039 & $74 \mathrm{~b}$ & 82,32 a & $154 \mathrm{a}$ & $93,05 \mathrm{a}$ & $3,75 \mathrm{a}$ & $55,63 \mathrm{~b}$ \\
\hline Numbaira & $67 \mathrm{e}$ & $66,33 \mathrm{~b}$ & $134 \mathrm{c}$ & $72,60 \mathrm{~b}$ & $4,23 a$ & $53,88 \mathrm{~b}$ \\
\hline BR-11 & $80 a$ & $77,90 \mathrm{a}$ & $144 b$ & 87,25 a & $4,00 \mathrm{a}$ & $46,62 \mathrm{~b}$ \\
\hline Tropical & $75 \mathrm{~b}$ & $75,50 \mathrm{a}$ & $149 a$ & $92,10 \mathrm{a}$ & $4,10 \mathrm{a}$ & $40,35 \mathrm{~b}$ \\
\hline Média Geral & 67 & 63,26 & 135 & 77,58 & 4,24 & 67,09 \\
\hline C.V. $(\%)$ & 1,32 & 9,03 & 2,41 & 6,48 & 9,00 & 20,56 \\
\hline
\end{tabular}

T Para a identificação dos caracteres e das unidades, consultar o Apêndice l. ${ }^{2}$ Médias calculadas com base em 2 repetições de 6 covas. ${ }^{3}$ Médias seguidas de mesma letra, na coluna, não diferem entre si pelo método de agrupamento de Scott-Knott $(\mathrm{P} \leq 0,05)$. 
Tabela 26 Médias e classi ficações para seis caracteres ${ }^{2}$, de 45 populações $\mathbf{F}_{2[4]}$ de cruzamentos quádruplos e de 4 testemunhas, com base em quatro repetições. Soja, Piracicaba - SP (semeadura 04/12/1992).

\begin{tabular}{|c|c|c|c|c|c|c|}
\hline \multirow[b]{2}{*}{ GENÓTIPOS ${ }^{1}$} & \multicolumn{5}{|c|}{ MEDIAS DOS CARACTERES } & \multirow[b]{2}{*}{$\begin{array}{c}\text { PG } \\
\text { g/planta }\end{array}$} \\
\hline & $\begin{array}{l}\text { NDF } \\
\text { dias }\end{array}$ & $\begin{array}{l}\mathrm{APF} \\
\mathrm{cm}\end{array}$ & $\begin{array}{l}\text { NDM } \\
\text { dias }\end{array}$ & $\begin{array}{c}\mathrm{APM} \\
\mathrm{cm}\end{array}$ & $\begin{array}{l}\text { VA } \\
\text { nota }\end{array}$ & \\
\hline 21 & $65 \mathrm{~d}$ & $66,34 \mathrm{c}$ & $140 \mathrm{~d}$ & $78,34 \mathrm{c}$ & $4,23 \mathrm{a}$ & $1 4 7 \longdiv { 7 , 9 8 a }$ \\
\hline Cristalina & $67 \mathrm{~d}$ & $62,26 \mathrm{c}$ & $149 \mathrm{c}$ & $81,19 \mathrm{c}$ & $4,37 \mathrm{a}$ & $140,57 \mathrm{a}$ \\
\hline 23 & $63 \mathrm{~d}$ & $65,86 \mathrm{c}$ & $137 \mathrm{e}$ & $86,04 \mathrm{c}$ & $4,12 \mathrm{a}$ & $139,02 \mathrm{a}$ \\
\hline 19 & $70 \mathrm{c}$ & $72,41 \mathrm{~b}$ & $141 \mathrm{~d}$ & $89,09 \mathrm{~b}$ & $4,54 \mathrm{a}$ & 137,96 a \\
\hline EMGOPA-301 & $72 \mathrm{c}$ & $77,77 \mathrm{~b}$ & $151 \mathrm{c}$ & $96,45 \mathrm{~b}$ & $4,53 \mathrm{a}$ & $135,56 \mathrm{a}$ \\
\hline 22 & $64 \mathrm{~d}$ & $61,66 \mathrm{c}$ & $139 \mathrm{~d}$ & $79,62 \mathrm{c}$ & $4,23 \mathrm{a}$ & $135,34 \mathrm{a}$ \\
\hline 16 & $69 c$ & $71,80 \mathrm{~b}$ & $146 \mathrm{c}$ & $92,10 \mathrm{~b}$ & $4,29 \mathrm{a}$ & $131,67 \mathrm{a}$ \\
\hline IAC-8 & $60 \mathrm{e}$ & $63,05 \mathrm{c}$ & $139 \mathrm{~d}$ & $78,94 \mathrm{c}$ & $3,74 \mathrm{~b}$ & $125,36 \mathrm{a}$ \\
\hline 10 & $67 d$ & $63,94 \mathrm{c}$ & $147 \mathrm{c}$ & $79,39 \mathrm{c}$ & $3,89 \mathrm{~b}$ & $119,41 \mathrm{~b}$ \\
\hline 20 & $60 \mathrm{e}$ & $61,34 \mathrm{~d}$ & $137 \mathrm{e}$ & $77,06 \mathrm{c}$ & $4,07 \mathrm{a}$ & $119,11 \mathrm{~b}$ \\
\hline SS-1 & $58 \mathrm{e}$ & $55,79 \mathrm{~d}$ & $127 \mathrm{e}$ & $78,13 \mathrm{c}$ & $4,01 \mathrm{a}$ & $119,05 \mathrm{~b}$ \\
\hline 40 & $69 c$ & $67,83 \mathrm{c}$ & $144 d$ & $83,40 \mathrm{c}$ & $4,33 \mathrm{a}$ & $118,79 \mathrm{~b}$ \\
\hline 8 & $69 c$ & $72,29 \mathrm{~b}$ & $149 \mathrm{c}$ & $88,76 \mathrm{~b}$ & $4,15 \mathrm{a}$ & $117,89 \mathrm{~b}$ \\
\hline 31 & $66 d$ & $64,63 \mathrm{c}$ & $142 \mathrm{~d}$ & $79,37 \mathrm{c}$ & $4,15 \mathrm{a}$ & $117,15 \mathrm{~b}$ \\
\hline 2 & $68 \mathrm{~d}$ & $67,01 \mathrm{c}$ & $143 \mathrm{~d}$ & $85,65 \mathrm{c}$ & $4,18 \mathrm{a}$ & $117,14 \mathrm{~b}$ \\
\hline 36 & $69 c$ & $77,54 \mathrm{~b}$ & $148 \mathrm{c}$ & $91,23 \mathrm{~b}$ & $4,23 \mathrm{a}$ & $116,26 \mathrm{~b}$ \\
\hline 26 & $64 \mathrm{~d}$ & $67,00 \mathrm{c}$ & $141 \mathrm{~d}$ & $98,47 \mathrm{~b}$ & $4,05 \mathrm{a}$ & $116,01 \mathrm{~b}$ \\
\hline 39 & $62 \mathrm{e}$ & $64,58 \mathrm{c}$ & $136 \mathrm{e}$ & $86,41 \mathrm{c}$ & $3,67 \mathrm{~b}$ & $115,55 \mathrm{~b}$ \\
\hline 29 & $60 \mathrm{e}$ & $60,02 \mathrm{~d}$ & $136 \mathrm{e}$ & $92,56 \mathrm{~b}$ & $3,89 \mathrm{~b}$ & $115,48 b$ \\
\hline 3 & $61 \mathrm{e}$ & $62,43 c$ & $141 \mathrm{~d}$ & $98,22 \mathrm{~b}$ & $3,68 \mathrm{~b}$ & $114,19 b$ \\
\hline 4 & $70 \mathrm{c}$ & $69,67 \mathrm{c}$ & $149 \mathrm{c}$ & $84,82 \mathrm{c}$ & $4,03 \mathrm{a}$ & $112,44 b$ \\
\hline 5 & $77 \mathrm{~b}$ & $81,13 \mathrm{~b}$ & $169 \mathrm{a}$ & $97,01 \mathrm{~b}$ & $4,29 \mathrm{a}$ & $112,37 \mathrm{~b}$ \\
\hline 6 & $77 \mathrm{~b}$ & $81,65 \mathrm{~b}$ & $160 \mathrm{~b}$ & $95,64 \mathrm{~b}$ & $4,45 \mathrm{a}$ & $111,85 \mathrm{~b}$ \\
\hline 12 & $71 \mathrm{c}$ & $74,72 \mathrm{~b}$ & $147 \mathrm{c}$ & $85,27 \mathrm{c}$ & $3,95 \mathrm{~b}$ & $111,58 \mathrm{~b}$ \\
\hline 15 & $64 d$ & $59,58 \mathrm{~d}$ & $142 \mathrm{~d}$ & $80,55 \mathrm{c}$ & $3,83 b$ & $110,97 b$ \\
\hline 33 & $64 \mathrm{~d}$ & $68,95 \mathrm{c}$ & $139 \mathrm{~d}$ & $96,60 \mathrm{~b}$ & $3,78 \mathrm{~b}$ & $109,94 \mathrm{~b}$ \\
\hline 27 & $67 \mathrm{~d}$ & $67,46 \mathrm{c}$ & $142 \mathrm{~d}$ & $82,59 \mathrm{c}$ & $3,88 \mathrm{~b}$ & $109,83 \mathrm{~b}$ \\
\hline 24 & $61 \mathrm{e}$ & $64,03 \mathrm{c}$ & $135 \mathrm{e}$ & $90,87 \mathrm{~b}$ & $3,56 \mathrm{~b}$ & $109,74 \mathrm{~b}$ \\
\hline 34 & $60 \mathrm{e}$ & $56,46 \mathrm{~d}$ & $133 \mathrm{e}$ & 91,72 b & $3,52 \mathrm{~b}$ & $108,21 \mathrm{~b}$ \\
\hline 38 & $60 \mathrm{e}$ & $65,27 \mathrm{c}$ & $135 \mathrm{e}$ & $74,78 \mathrm{c}$ & $3,40 \mathrm{~b}$ & $108,00 \mathrm{~b}$ \\
\hline 18 & $61 \mathrm{e}$ & $58,16 \mathrm{~d}$ & $143 \mathrm{~d}$ & $94,51 \mathrm{~b}$ & $3,70 \mathrm{~b}$ & $107,72 \mathrm{~b}$ \\
\hline 35 & $61 \mathrm{e}$ & $63,14 \mathrm{c}$ & $135 \mathrm{e}$ & $83,55 \mathrm{c}$ & $3,67 b$ & $107,43 \mathrm{~b}$ \\
\hline 1 & $69 c$ & $68,52 \mathrm{c}$ & $153 \mathrm{c}$ & $80,19 c$ & $3,51 \mathrm{~b}$ & $106,36 \mathrm{~b}$ \\
\hline 13 & $65 \mathrm{~d}$ & $71,09 \mathrm{~b}$ & $142 \mathrm{~d}$ & $87,58 \mathrm{c}$ & $3,92 \mathrm{~b}$ & $105,95 \mathrm{~b}$ \\
\hline 41 & $61 \mathrm{e}$ & $61,82 \mathrm{c}$ & $136 \mathrm{e}$ & $77,16 \mathrm{c}$ & $3,46 \mathrm{~b}$ & $104,69 \mathrm{~b}$ \\
\hline 14 & $76 \mathrm{~b}$ & $76,56 \mathrm{~b}$ & $154 \mathrm{c}$ & $86,07 \mathrm{c}$ & $4,27 \mathrm{a}$ & $104,19 \mathrm{~b}$ \\
\hline 37 & $69 c$ & $71,68 b$ & $149 \mathrm{c}$ & $88,48 \mathrm{~b}$ & $4,39 a$ & $103,88 \mathrm{~b}$ \\
\hline 9 & $90 \mathrm{a}$ & 96,95 a & $176 \mathrm{a}$ & $119,11 \mathrm{a}$ & $3,96 \mathrm{~b}$ & $103,08 \mathrm{~b}$ \\
\hline 25 & $64 d$ & $63,04 \mathrm{c}$ & $140 \mathrm{~d}$ & $94,86 \mathrm{~b}$ & $3,64 \mathrm{~b}$ & $102,45 \mathrm{~b}$ \\
\hline 30 & $58 \mathrm{e}$ & $58,77 \mathrm{~d}$ & $129 \mathrm{e}$ & $79,57 \mathrm{c}$ & $3,49 \mathrm{~b}$ & $101,44 \mathrm{~b}$ \\
\hline 32 & $61 \mathrm{e}$ & $59,74 \mathrm{~d}$ & $135 \mathrm{e}$ & $81,94 \mathrm{c}$ & $3,44 \mathrm{~b}$ & $101,43 \mathrm{~b}$ \\
\hline 45 & $57 \mathrm{e}$ & $55,36 \mathrm{~d}$ & $130 \mathrm{e}$ & $80,60 \mathrm{c}$ & $3,33 \mathrm{~b}$ & $100,80 \mathrm{~b}$ \\
\hline 11 & $60 \mathrm{e}$ & $57,33 \mathrm{~d}$ & $141 \mathrm{~d}$ & $79,60 \mathrm{c}$ & $3,54 \mathrm{~b}$ & $100,74 \mathrm{~b}$ \\
\hline 17 & $78 \mathrm{~b}$ & $80,89 \mathrm{~b}$ & $164 \mathrm{~b}$ & $99,98 \mathrm{~b}$ & $3,86 \mathrm{~b}$ & 99,78 b \\
\hline 42 & $59 \mathrm{e}$ & $53,45 \mathrm{~d}$ & $133 \mathrm{e}$ & $69,22 \mathrm{c}$ & $3,19 \mathrm{~b}$ & $99,14 \mathrm{~b}$ \\
\hline 44 & $66 \mathrm{~d}$ & $62,24 \mathrm{c}$ & $140 \mathrm{~d}$ & $84,24 \mathrm{c}$ & $3,86 \mathrm{~b}$ & $98,01 \mathrm{~b}$ \\
\hline 7 & $72 \mathrm{c}$ & $75,33 \mathrm{~b}$ & $149 \mathrm{c}$ & $85,97 \mathrm{c}$ & $3,85 \mathrm{~b}$ & $97,82 \mathrm{~b}$ \\
\hline 43 & $62 \mathrm{e}$ & $60,29 d$ & $141 \mathrm{~d}$ & $93,33 \mathrm{~b}$ & $3,90 \mathrm{~b}$ & $96,99 \mathrm{~b}$ \\
\hline 28 & $65 \mathrm{~d}$ & $65,00 \mathrm{c}$ & $141 \mathrm{~d}$ & $92,33 \mathrm{~b}$ & $3,91 \mathrm{~b}$ & $95,42 \mathrm{~b}$ \\
\hline MEDIA GERAL & 66 & 67,00 & 143 & 86,91 & 3,92 & 113,10 \\
\hline C.V. (\%) & 5,37 & 9,31 & 4,38 & 8,40 & 9,75 & 14,98 \\
\hline
\end{tabular}

Para identificar os cruzamentos que originaram estas populações $F_{2[4]}$ consultar o Apêndice 6 .

${ }^{2}$ Para identificar os caracteres e unidades, consultar o Apêndice 1. ${ }^{2(4)}$ Médias seguidas de mesma letra, na coluna, pertencem a um grupo comum, e não diferem pelo método do agnupamento de $\operatorname{Scott-knott}(\mathrm{P} \leq 0,05)$. 
Tabela 27 Médias e classificações de seis caracteres ${ }^{2}$, para 45 populaçōes $\mathbf{F}_{3: 2[4]}$ de cruzamentos quádruplos e de 4 testemunhas, com base em quatro repetições. Soja. Maracaí - SP (semeadura 02/12/1993).

\begin{tabular}{|c|c|c|c|c|c|c|}
\hline \multirow[b]{2}{*}{ GENÓTIPOS ${ }^{1}$} & \multicolumn{6}{|c|}{ MÉDIAS DOS CARACTERES ${ }^{2,3}$} \\
\hline & $\begin{array}{r}\text { NDF } \\
\text { dias }\end{array}$ & $\begin{array}{l}\mathrm{APF} \\
\mathrm{cm}\end{array}$ & $\begin{array}{l}\text { NDM } \\
\text { dias }\end{array}$ & $\begin{array}{c}\mathrm{APM} \\
\mathrm{cm}\end{array}$ & $\begin{array}{l}\text { VAG } \\
\text { nota }\end{array}$ & $\begin{array}{c}\mathrm{PG} \\
\mathrm{g} / \text { plant a }\end{array}$ \\
\hline Cristalina & $67 \mathrm{c}$ & $54,75 \mathrm{~d}$ & $134 \mathrm{c}$ & $65,65 \mathrm{~d}$ & $4,17 \mathrm{a}$ & $82,17 a$ \\
\hline EMGOPA-301 & $71 \mathrm{~b}$ & $71,07 \mathrm{~b}$ & $143 \mathrm{~b}$ & $79,95 \mathrm{~b}$ & $4,40 \mathrm{a}$ & 81,91 a \\
\hline 23 & $67 \mathrm{c}$ & $64,51 \mathrm{c}$ & $132 \mathrm{c}$ & $74,79 \mathrm{c}$ & $4,36 \mathrm{a}$ & $75,23 \mathrm{a}$ \\
\hline 3 & $65 \mathrm{c}$ & $62,32 \mathrm{c}$ & $132 \mathrm{c}$ & $90,12 \mathrm{~b}$ & $3,79 \mathrm{~b}$ & $74,98 \mathrm{a}$ \\
\hline 6 & $75 \mathrm{a}$ & $72,26 \mathrm{~b}$ & $147 \mathrm{a}$ & $83,05 \mathrm{~b}$ & 4,12 a & 74,67 a \\
\hline 21 & $66 \mathrm{c}$ & $57,73 \mathrm{c}$ & $130 \mathrm{c}$ & $66,35 \mathrm{~d}$ & 3,96 a & $73,38 \mathrm{a}$ \\
\hline 34 & $63 \mathrm{~d}$ & $53,75 \mathrm{~d}$ & $130 \mathrm{c}$ & $81,78 \mathrm{~b}$ & $3,80 \mathrm{~b}$ & $71,12 \mathrm{a}$ \\
\hline 41 & $59 \mathrm{~d}$ & $46,72 \mathrm{~d}$ & $125 \mathrm{~d}$ & $63,34 \mathrm{~d}$ & $3,75 \mathrm{~b}$ & 70,11 a \\
\hline 29 & $62 \mathrm{~d}$ & $57,56 \mathrm{c}$ & $127 \mathrm{~d}$ & $81,76 \mathrm{~b}$ & $3,94 \mathrm{a}$ & $68,33 \mathrm{a}$ \\
\hline 22 & $66 \mathrm{c}$ & $56,01 \mathrm{c}$ & $130 \mathrm{c}$ & $64,57 \mathrm{~d}$ & 3,99 a & $67,62 \mathrm{a}$ \\
\hline IAC-8 & $63 \mathrm{~d}$ & $62,75 \mathrm{c}$ & $127 \mathrm{~d}$ & $70,72 \mathrm{c}$ & 3,89 a & $67,18 \mathrm{a}$ \\
\hline 19 & $68 \mathrm{c}$ & $57,52 \mathrm{c}$ & $132 \mathrm{c}$ & $66,99 \mathrm{~d}$ & $4,15 \mathrm{a}$ & 66,85 a \\
\hline SS-1 & $59 \mathrm{~d}$ & $52,18 \mathrm{~d}$ & $117 \mathrm{~d}$ & $61,77 \mathrm{~d}$ & $4,36 \mathrm{a}$ & $64,10 \mathrm{a}$ \\
\hline 9 & $77 \mathrm{a}$ & $92,54 \mathrm{a}$ & $155 \mathrm{a}$ & $121,58 \mathrm{a}$ & $3,60 \mathrm{~b}$ & $63,79 a$ \\
\hline 20 & $64 \mathrm{c}$ & $58,67 \mathrm{c}$ & $130 \mathrm{c}$ & $65,14 \mathrm{~d}$ & $3,97 \mathrm{a}$ & $63,79 a$ \\
\hline 8 & $69 \mathrm{~b}$ & $71,24 \mathrm{~b}$ & $139 \mathrm{~b}$ & 84,19 b & $3,89 a$ & $63,56 a$ \\
\hline 24 & $65 \mathrm{c}$ & $61,69 \mathrm{c}$ & $127 \mathrm{~d}$ & $81,33 \mathrm{~b}$ & $3,89 \mathrm{a}$ & 62,61 a \\
\hline 44 & $67 c$ & $57,68 \mathrm{c}$ & $131 \mathrm{c}$ & $71,93 \mathrm{c}$ & $4,10 \mathrm{a}$ & $61,85 \mathrm{~b}$ \\
\hline 35 & $63 \mathrm{~d}$ & $57,22 \mathrm{c}$ & $124 \mathrm{~d}$ & $71,81 \mathrm{c}$ & $3,95 \mathrm{a}$ & $61,49 b$ \\
\hline 36 & $67 \mathrm{c}$ & $62,86 \mathrm{c}$ & $135 \mathrm{c}$ & $69,25 \mathrm{c}$ & $3,61 \mathrm{~b}$ & $61,10 \mathrm{~b}$ \\
\hline 39 & $62 \mathrm{~d}$ & $60,11 \mathrm{c}$ & $124 \mathrm{~d}$ & $73,99 \mathrm{c}$ & $3,71 b$ & $61,00 \mathrm{~b}$ \\
\hline 15 & $68 \mathrm{c}$ & $64,06 \mathrm{c}$ & $134 \mathrm{c}$ & $72,40 \mathrm{c}$ & $4,04 \mathrm{a}$ & $60,67 b$ \\
\hline 27 & $67 c$ & $60,33 \mathrm{c}$ & $129 \mathrm{c}$ & $69,28 \mathrm{c}$ & $3,74 b$ & $59,96 \mathrm{~b}$ \\
\hline 28 & $66 \mathrm{c}$ & $61,20 \mathrm{c}$ & $134 \mathrm{c}$ & $79,41 \mathrm{~b}$ & $3,90 \mathrm{a}$ & $59,92 \mathrm{~b}$ \\
\hline 7 & $67 \mathrm{c}$ & $62,79 \mathrm{c}$ & $133 \mathrm{c}$ & $74,82 \mathrm{c}$ & $3,85 \mathrm{a}$ & $59,71 \mathrm{~b}$ \\
\hline 33 & $65 \mathrm{c}$ & $60,54 \mathrm{c}$ & $127 \mathrm{~d}$ & $76,96 \mathrm{~b}$ & $3,71 \mathrm{~b}$ & $58,17 \mathrm{~b}$ \\
\hline 45 & $59 \mathrm{~d}$ & $45,51 \mathrm{~d}$ & $124 \mathrm{~d}$ & $62,31 \mathrm{~d}$ & $3,64 b$ & $58,11 \mathrm{~b}$ \\
\hline 30 & $59 \mathrm{~d}$ & $47,23 \mathrm{~d}$ & $119 \mathrm{~d}$ & $64,10 \mathrm{~d}$ & $3,95 \mathrm{a}$ & $57,90 \mathrm{~b}$ \\
\hline 32 & $61 \mathrm{~d}$ & $49,62 \mathrm{~d}$ & $123 \mathrm{~d}$ & $60,04 \mathrm{~d}$ & $3,63 \mathrm{~b}$ & $57,43 \mathrm{~b}$ \\
\hline 16 & $69 \mathrm{~b}$ & $62,23 \mathrm{c}$ & $137 \mathrm{c}$ & $71,80 \mathrm{c}$ & $3,91 \mathrm{a}$ & $57,25 b$ \\
\hline 42 & $60 \mathrm{~d}$ & $48,79 \mathrm{~d}$ & $123 \mathrm{~d}$ & $54,44 \mathrm{~d}$ & $3,27 \mathrm{~b}$ & $57,16 \mathrm{~b}$ \\
\hline 18 & $65 \mathrm{c}$ & $56,08 \mathrm{c}$ & $134 \mathrm{c}$ & $84,43 \mathrm{~b}$ & $3,79 \mathrm{~b}$ & $56,94 \mathrm{~b}$ \\
\hline 10 & $66 \mathrm{c}$ & $57,55 \mathrm{c}$ & $137 \mathrm{c}$ & $65,53 \mathrm{~d}$ & $3,57 \mathrm{~b}$ & $56,49 \mathrm{~b}$ \\
\hline 11 & $63 \mathrm{~d}$ & $53,56 \mathrm{~d}$ & $132 \mathrm{c}$ & $69,72 \mathrm{c}$ & $3,69 \mathrm{~b}$ & $56,15 \mathrm{~b}$ \\
\hline 40 & $68 \mathrm{c}$ & $60,02 \mathrm{c}$ & $135 \mathrm{c}$ & $70,03 \mathrm{c}$ & $3,89 a$ & $55,66 \mathrm{~b}$ \\
\hline 14 & $65 \mathrm{c}$ & $56,42 \mathrm{c}$ & $132 \mathrm{c}$ & $66,86 \mathrm{~d}$ & $4,02 \mathrm{a}$ & $55,37 \mathrm{~b}$ \\
\hline 37 & $73 a$ & $71,53 \mathrm{~b}$ & $143 \mathrm{~b}$ & $80,56 \mathrm{~b}$ & $3,94 \mathrm{a}$ & $54,62 \mathrm{~b}$ \\
\hline 4 & $71 \mathrm{~b}$ & $62,80 \mathrm{c}$ & $138 \mathrm{c}$ & $71,36 \mathrm{c}$ & $3,90 \mathrm{a}$ & $54,11 \mathrm{~b}$ \\
\hline 43 & $65 \mathrm{c}$ & $56,60 \mathrm{c}$ & $135 \mathrm{c}$ & $83,27 \mathrm{~b}$ & $3,68 b$ & $53,85 b$ \\
\hline 12 & $72 b$ & $69,22 \mathrm{~b}$ & $143 \mathrm{~b}$ & $83,95 \mathrm{~b}$ & $3,60 \mathrm{~b}$ & $53,85 \mathrm{~b}$ \\
\hline 13 & $65 \mathrm{c}$ & $60,00 \mathrm{c}$ & $135 \mathrm{c}$ & $69,37 \mathrm{c}$ & $3,40 \mathrm{~b}$ & $53,77 b$ \\
\hline 2 & $70 \mathrm{~b}$ & $61,78 \mathrm{c}$ & $137 \mathrm{c}$ & $71,30 \mathrm{c}$ & $3,75 \mathrm{~b}$ & $50,03 \mathrm{~b}$ \\
\hline 31 & $69 \mathrm{~b}$ & $62,92 \mathrm{c}$ & $132 \mathrm{c}$ & $68,25 \mathrm{c}$ & $3,63 \mathrm{~b}$ & $49,44 \mathrm{~b}$ \\
\hline 5 & $75 \mathrm{a}$ & $74,44 \mathrm{~b}$ & $156 \mathrm{a}$ & $81,01 \mathrm{~b}$ & $3,77 \mathrm{~b}$ & $49,43 \mathrm{~b}$ \\
\hline 26 & $66 \mathrm{c}$ & $58,86 \mathrm{c}$ & $130 \mathrm{c}$ & $71,18 \mathrm{c}$ & $3,74 \mathrm{~b}$ & $49,14 b$ \\
\hline 1 & $69 \mathrm{~b}$ & $63,89 \mathrm{c}$ & $142 \mathrm{~b}$ & $73,17 \mathrm{c}$ & $3,37 \mathrm{~b}$ & $47,51 \mathrm{~b}$ \\
\hline 25 & $64 \mathrm{c}$ & $58,13 \mathrm{c}$ & $135 \mathrm{c}$ & $82,71 \mathrm{~b}$ & $3,59 \mathrm{~b}$ & $46,17 b$ \\
\hline 38 & $60 \mathrm{~d}$ & $52,07 d$ & $121 \mathrm{~d}$ & $59,56 \mathrm{~d}$ & $3,35 \mathrm{~b}$ & $45,72 \mathrm{~b}$ \\
\hline 17 & $76 \mathrm{a}$ & $70,49 b$ & $149 \mathrm{a}$ & $85,74 \mathrm{~b}$ & $3,52 \mathrm{~b}$ & $41,02 b$ \\
\hline MÉDIA GERAL & 66 & 60,40 & 133 & 73,75 & 3,82 & 60,25 \\
\hline C.V. $(\%)$ & 4,52 & 8,83 & 4,77 & 9,66 & 8,65 & 20,11 \\
\hline
\end{tabular}

7 Para identificar os cruzamentos que originaram estas populações $F_{3: 2[4]}$, consultar o Apêndice 6 .

${ }^{2}$ Para identificar os caracteres consultar o Apêndice $1 .{ }^{3}$ Médias seguidas de mesma letra, na coluna, pertencem a um grupo comum, e não diferem pelo método do agrupamento de Scott-knott $(\mathrm{P} \leq 0,05)$. 
Tabela 28 Estimativas de covariâncias fenotípicas (COV F), residuais (COV E) e genotipicas (COV G), entre seis caracteres ${ }^{1}$ combinados dois a dois, com base em quatro repetições, de testemunhas ${ }^{2}$ e populações $\mathbf{F}_{2[4]}$ e $\mathbf{F}_{3: 2[4]}$ de 45 cruzamentos quádruplos ${ }^{3}$. Soja, Piracicaba - SP (semeadura 04/12/1992) e Maracaí - SP (semeadura 02/12/1993).

\begin{tabular}{|c|c|c|c|c|c|c|}
\hline \multirow[b]{2}{*}{ CARACTERES $^{1}$} & \multicolumn{6}{|c|}{ COVARIANNCIAS } \\
\hline & COVF & COVE & $\mathrm{COVG}$ & $\mathrm{COVF}$ & COVE & COV G \\
\hline & \multirow{2}{*}{\multicolumn{6}{|c|}{$\begin{array}{l}\text { PIRACICABA }-1992 / 93 \\
\text { TESTEMUNHAS }\end{array}$}} \\
\hline & \multicolumn{2}{|c|}{ TESTEMUNAAS } & & & \multicolumn{2}{|c|}{ POPULAÇÖES ${ }^{3} F_{2[4]}$} \\
\hline NDFXAPF & 222,85 & 0,32 & 55,63 & 202,69 & 14,26 & 47,11 \\
\hline NDFxNDM & 276,66 & 1,39 & 68,82 & 233,06 & 18,49 & 53,64 \\
\hline NDFxAPM & 207,44 & $-0,50$ & 51,99 & 129,01 & 10,40 & 29,65 \\
\hline NDFxVA & 8,68 & $-0,34$ & 2,26 & 4,77 & 0,54 & 1,06 \\
\hline NDFxPG & 225,50 & $-0,92$ & 56,61 & 3,12 & 7,68 & $-1,14$ \\
\hline APFxNDM & 322,12 & $-0,31$ & 80,61 & 280,10 & 22,37 & 64,43 \\
\hline APFxAPM & 306,95 & 2,62 & 76,08 & 177,28 & 34,86 & 35,61 \\
\hline APFxVA & 8,52 & 0,08 & 2,11 & 6,14 & 0,84 & 1,33 \\
\hline APFxPG & 202,95 & $-16,54$ & 54,87 & 25,90 & 9,03 & 4,22 \\
\hline NDMxAPM & 263,82 & 7,28 & 64,14 & 195,55 & 22,28 & 43,32 \\
\hline NDMxVA & 11,22 & 0,53 & 2,67 & 6,05 & 0,65 & 1,35 \\
\hline NDMxPG & 399,74 & 6,82 & 98,23 & $-29,88$ & $-4,75$ & $-6,28$ \\
\hline APMxVA & 9,40 & 1,48 & 1,98 & 3,16 & 0,86 & 0,58 \\
\hline APMxPG & 169,99 & $-12,40$ & 45,60 & $-41,93$ & 3,37 & $-11,33$ \\
\hline \multirow[t]{3}{*}{ VA $\times P G$} & 10,57 & 0,73 & 2,46 & 8,74 & 3,23 & 1,38 \\
\hline & \multicolumn{6}{|c|}{ MARACAİ - 1993/94 } \\
\hline & \multicolumn{3}{|c|}{ TESTEMUNHAS $^{2}$} & \multicolumn{3}{|c|}{ POPULAÇÕES ${ }^{3} F_{3: 2[4]}$} \\
\hline NDFxAPF & 129,23 & $-0,49$ & 32,43 & 130,62 & 10,53 & 30,02 \\
\hline NDFxNDM & 228,57 & 1,96 & 56,65 & 133,20 & 17,00 & 29,05 \\
\hline NDFxAPM & 132,00 & $-0,97$ & 33,24 & 115,17 & 13,07 & 25,53 \\
\hline NDFxVA & 1,47 & $-0,33$ & 0,45 & 0,51 & 0,05 & 0,12 \\
\hline NDFxPG & 184,14 & 1,90 & 45,56 & $-23,65$ & $-5,83$ & $-4,46$ \\
\hline APFxNDM & 290,28 & 1,01 & 72,32 & 229,32 & 20,05 & 52,32 \\
\hline APFxAPM & 266,29 & 11,39 & 63,73 & 282,38 & 33,20 & 62,30 \\
\hline APFxVA & 0,39 & 0,07 & 0,08 & 0,60 & 0,52 & 0,02 \\
\hline APFxPG & 138,00 & 7,72 & 32,57 & $-9,30$ & 15,87 & $-6,29$ \\
\hline NDMxAPM & 291,62 & 0,97 & 72,66 & 232,59 & 27,40 & 51,30 \\
\hline NDMxVA & 1,54 & $-0,26$ & 0,45 & $-0,17$ & 0,04 & $-0,05$ \\
\hline NDMxPG & 384,14 & $-12,20$ & 99,09 & $-53,58$ & $-13,56$ & $-10,00$ \\
\hline APMxVAG & 0,83 & 0,38 & 0,11 & 0,53 & 0,59 & $-0,02$ \\
\hline APMxPG & 159,37 & 9,70 & 37,42 & 36,58 & 18,93 & 4,41 \\
\hline VA $\times P G$ & 2,59 & 2,41 & 0,05 & 4,31 & 2,70 & 0,40 \\
\hline
\end{tabular}

${ }^{1}$ Para identificar os caracteres, consultar o Apêndice 1.

${ }^{2}$ Testemunhas = Cristalina, EMGOPA-301, IAC-8 e SS-1 (OCEPAR-9).

${ }^{3}$ Para identificar os cruzamentos que deram origem a estas populações, consultar o Apêndice 6. 
Tabela 29 Estimativas de correlações fenotípicas $\left(\mathrm{r}_{\mathrm{F}}\right)$, residuais $\left(\mathrm{I}_{\mathrm{E}}\right)$ e genotípicas $\left(\mathrm{r}_{\mathrm{G}}\right)$, entre seis caracteres ${ }^{1}$, combinados dois a dois, com base em quatro repetições de testemunhas ${ }^{2}$ e de populaçōes $\mathbf{F}_{2[4]}$ e $\mathbf{F}_{3: 2[4]}$ de 45 cruzamentos quádruplos ${ }^{3}$. Soja, Piracicaba - SP (semeadura 04/12/92) e Maracaí - SP (semeadura 02/12/93).

\begin{tabular}{|c|c|c|c|c|c|c|}
\hline \multirow[t]{2}{*}{ CARACTERES $^{1}$} & \multicolumn{6}{|c|}{ CORRELAÇÕES } \\
\hline & $\mathrm{r}_{\mathrm{F}}$ & $\mathrm{r}_{\mathrm{E}}$ & $\mathrm{r}_{\mathrm{G}}$ & $\overline{\mathrm{r}_{\mathrm{F}}}$ & $\mathrm{r}_{\mathrm{E}}$ & $\overline{I_{G}}$ \\
\hline & \multicolumn{6}{|c|}{ PIRACICABA - 1992/93 } \\
\hline & \multicolumn{3}{|c|}{ TESTEMUNHAS $^{2}$} & \multicolumn{3}{|c|}{ POPULAÇÕES ${ }^{3} F_{2\lceil 4\rceil}$} \\
\hline NDFxAPF & $0,88^{* *}$ & 0,08 & $0,89^{* *}$ & $0,94^{* *}$ & 0,61 & $0,99 *$ \\
\hline NDFxNDM & $0,93^{* *}$ & 0,23 & $0,94^{* *}$ & $0,94^{* *}$ & 0,78 & $0,96^{* *}$ \\
\hline NDFXAPM & $0,88^{* *}$ & $-0,07$ & $0,92^{* *}$ & $0,58^{* *}$ & 0,38 & $0,62^{* *}$ \\
\hline NDFxVA & $0,89^{* *}$ & $-0,37$ & $1,24^{* *}$ & $0,56^{* *}$ & 0,39 & $0,64^{* *}$ \\
\hline NDFxPG & $0,85^{* *}$ & $-0,03$ & $1,33^{* *}$ & $0,01^{\mathrm{ns}}$ & 0,12 & $-0,02^{\mathrm{ns}}$ \\
\hline APFXNDM & $0,79^{* *}$ & $-0,05$ & $0,80^{* *}$ & $0,88^{* *}$ & 0,54 & $0,93^{* *}$ \\
\hline APFXAPM & $0,96^{* *}$ & 0,34 & $0,98_{* *}^{* *}$ & $0,62_{* *}^{* *}$ & 0,72 & $0,60^{* *}$ \\
\hline APFxVA & $0,64^{* *}$ & 0,08 & $0,85^{* *}$ & $0,56^{* *}$ & 0,35 & $0,64^{* *}$ \\
\hline APFxPG & $0,56^{* *}$ & $-0,55$ & $0,94^{* *}$ & $0,07^{\text {ns }}$ & 0,08 & $0,07^{\mathrm{ns}}$ \\
\hline NDMXAPM & $0,70^{* *}$ & 0,63 & $0,70^{* *}$ & $0,59^{* *}$ & 0,46 & $0,62^{* *}$ \\
\hline NDMxVA & $0,72^{* *}$ & 0,38 & $0,91^{* *}$ & $0,48^{* *}$ & 0,27 & $0,56^{* *}$ \\
\hline NDMxPG & $0,94^{* *}$ & 0,15 & $1,43^{* *}$ & $-0,07^{\mathrm{ns}}$ & $-0,04$ & $-0,09^{\text {ns }}$ \\
\hline APMxVA & $0,76^{* *}$ & 0,82 & $0,88^{* *}$ & $0,28^{\text {ns }}$ & 0,31 & $0,28^{\text {ns }}$ \\
\hline $\mathrm{APMxPG}$ & $0,51^{* *}$ & $-0,22$ & $0,86^{* *}$ & $-0,10^{\text {ns }}$ & 0,03 & $-0,18^{\mathrm{ns}}$ \\
\hline$V A \times P G$ & $0,76^{* *}$ & 0,11 & $1,45^{* *}$ & $0,57^{* *}$ & 0,51 & $0,64^{* *}$ \\
\hline
\end{tabular}

\section{TESTEMUNHAS $^{2}$ MARACAÍ - 1993/94 POPULAÇÕES ${ }^{3} F_{3: 2\{4]}$}

\begin{tabular}{llrlrrr} 
NDFXAPF & $0,73^{* *}$ & $-0,08$ & $0,76^{* *}$ & $0,90^{* *}$ & 0,62 & $0,93^{* *}$ \\
NDFxNDM & $0,99^{* *}$ & 0,41 & $1,00^{* *}$ & $0,92^{* *}$ & 0,84 & $0,94^{* *}$ \\
NDFXAPM & $0,81^{* * *}$ & $-0,16$ & $0,85^{* *}$ & $0,60^{* *}$ & 0,58 & $0,60^{* *}$ \\
NDFXVA & $0,30^{* *}$ & $-0,48$ & $0,78^{* *}$ & $0,13^{\text {ns }}$ & 0,05 & $0,20^{\text {ns }}$ \\
NDFXPG & $0,93^{* *}$ & 0,09 & $1,20^{* *}$ & $-0,17^{\text {ns }}$ & $-0,16$ & $-0,20^{\text {ns }}$ \\
APFxNDM & $0,76^{* *}$ & 0,10 & $0,79^{* *}$ & $0,85^{* *}$ & 0,56 & $0,90^{* *}$ \\
APFxAPM & $0,99^{* *}$ & 0,87 & $1,00^{* *}$ & $0,78^{* *}$ & 0,83 & $0,78^{* *}$ \\
APFXVA & $0,05^{\text {ns }}$ & 0,05 & $0,10^{\text {ns }}$ & $0,08^{\text {ns }}$ & 0,29 & $0,02^{\text {ns }}$ \\
APFxPG & $0,42^{* *}$ & 0,17 & $0,53^{* *}$ & $-0,03^{\text {ns }}$ & 0,24 & $-0,15^{\text {ns }}$ \\
NDMXAPM & $0,83^{* *}$ & 0,10 & $0,86^{* *}$ & $0,65^{* *}$ & 0,57 & $0,67^{* *}$ \\
NDMxVA & $0,15^{\text {ns }}$ & $-0,22$ & $0,36^{* *}$ & $-0,02^{\text {ns }}$ & 0,02 & $-0,01^{\text {ns }}$ \\
NDMxPG & $0,90^{* *}$ & $-0,36$ & $1,21^{* *}$ & $-0,20^{\text {ns }}$ & $-0,17$ & $-0,25^{\text {ns }}$ \\
APMxVA & $0,11^{\text {ns }}$ & 0,26 & $0,13^{\text {ns }}$ & $0,05^{\text {ns }}$ & 0,25 & $-0,01^{\text {ns }}$ \\
APMxPG & $0,53^{* * *}$ & 0,23 & $0,66^{* *}$ & $0,10^{\text {ns }}$ & 0,21 & $0,08^{\text {ns }}$ \\
VAx PG & $0,29^{* *}$ & 0,49 & $0,06^{\text {ns }}$ & $0,60^{* *}$ & 0,68 & $0,53^{* *}$ \\
\hline
\end{tabular}

** , Significativo ao nivel de le $5 \%$ pelo teste "t", respectivamente.

${ }^{\text {ns }}$ Não significativo.

${ }^{1}$ Para identificação dos caracteres, consultar o Apêndice 1.

${ }^{2}$ Testemunhas: Cristalina, EMGOPA-301, IAC-8 e SS-1 (OCEPAR-9).

${ }^{3}$ Para identificação dos cruzamentos, consultar o Apêndice 6. 
Tabela 30 Estimativas de correlações fenotípicas de Pearson, entre seis caracteres, combinados dois a dois, com N plantas dentro de cada população $F_{2[4]}$ e $F_{3: 2[4]}$ de cruzamentos quádruplos. Soja. Piracicaba S P. (semeadura 04/12/92) e Maracaí - S P (semeadura 02/12/93).

\begin{tabular}{|c|c|c|c|c|c|c|c|c|c|c|}
\hline \multirow[t]{2}{*}{ CARACTERES $^{1}$} & \multicolumn{10}{|c|}{ POPULAÇÕES ${ }^{2}$} \\
\hline & 1 & 2 & 3 & 4 & 5 & 6 & 7 & 8 & 9 & 10 \\
\hline & \multicolumn{10}{|c|}{ GERAÇÃO $F_{2\lceil 4\rceil}$ - PIRACICABA -1992/93 } \\
\hline NDF $\times$ APF & 0,87 & 0,69 & 0,70 & 0,81 & 0,89 & 0,84 & 0,91 & 0,86 & 0,76 & 0,72 \\
\hline NDF $x$ NDM & 0,91 & 0,80 & 0,83 & 0,88 & 0,93 & 0,86 & 0,91 & 0,88 & 0,91 & 0,90 \\
\hline NDF x APM & 0,79 & 0,60 & $0,31^{\text {ns }}$ & 0,60 & 0,85 & 0,60 & 0,72 & 0,86 & 0,72 & 0,69 \\
\hline NDF $x$ VA & 0,55 & $0,25^{\text {ns }}$ & $-0,17^{\text {ns }}$ & $-0,02^{\text {ns }}$ & $0,28^{\mathrm{ns}}$ & 0,40 & 0,37 & $0,29^{\text {ns }}$ & $0,17^{\text {ns }}$ & $0,24^{\text {ns }}$ \\
\hline NDF $\times$ PG & $0,09^{\text {ns }}$ & $0,04^{n s}$ & $-0,10^{\text {ns }}$ & $-0,23^{n s}$ & $-0,08^{\text {ns }}$ & $-0,21^{\mathrm{ns}}$ & $0,01^{\mathrm{ns}}$ & $0,20^{\text {ns }}$ & $-0,09^{\text {ns }}$ & $0,14^{\text {ns }}$ \\
\hline APF x NDM & 0,85 & 0,62 & 0,51 & 0,77 & 0,81 & 0,73 & 0,75 & 0,73 & 0,72 & 0,73 \\
\hline APF $\times$ APM & 0,89 & 0,75 & 0,37 & 0,85 & 0,87 & 0,75 & 0,85 & 0,80 & 0,77 & 0,85 \\
\hline APF $x$ VA & 0,60 & 0,45 & $-0,18^{\mathrm{ns}}$ & $0,06^{\text {ns }}$ & 0,32 & 0,45 & 0,51 & $0,30^{\mathrm{ns}}$ & $0,22^{\text {ns }}$ & 0,46 \\
\hline APF $\times$ PG & $0,25^{\mathrm{ns}}$ & $0,29^{\text {ns }}$ & $-0,11^{\text {ns }}$ & $0,00^{\text {ns }}$ & $-0,07^{\text {ns }}$ & $-0,05^{\mathrm{ns}}$ & $0,22^{\text {ns }}$ & $0,20^{\text {ns }}$ & $0,10^{\text {ns }}$ & 0,50 \\
\hline NDM $\times$ APM & 0,86 & 0,50 & $0,23^{\text {ns }}$ & 0,72 & 0,75 & 0,52 & 0,61 & 0,74 & 0,70 & 0,71 \\
\hline NDM $x$ VA & 0,54 & 0,34 & $-0,19^{\text {ns }}$ & $0,17^{\text {ns }}$ & $0,28^{\text {ns }}$ & 0,31 & $0,31^{\mathrm{ns}}$ & $0,31^{\mathrm{ns}}$ & $0,12^{\mathrm{ns}}$ & $0,27^{\text {ns }}$ \\
\hline NDM x PG & $0,13^{\mathrm{ns}}$ & $0,16^{\text {ns }}$ & $-0,11^{\mathrm{ns}}$ & $-0,05^{\text {ns }}$ & $-0,10^{\text {ns }}$ & $-0,10^{\mathrm{ns}}$ & $0,08^{\text {ns }}$ & $0,08^{\mathrm{ns}}$ & $-0,30^{\text {ns }}$ & $0,26^{\text {ns }}$ \\
\hline APM $\times$ VA & 0,64 & 0,45 & $0,10^{\mathrm{ns}}$ & $0,15^{\text {ns }}$ & 0,44 & 0,56 & 0,59 & 0,44 & $0,17^{\text {ns }}$ & 0,66 \\
\hline$A P M \times P G$ & 0,37 & 0,32 & $0,27^{\text {ns }}$ & $0,15^{\text {ns }}$ & $0,09^{\text {ns }}$ & $0,02^{\text {ns }}$ & 0,43 & $0,19^{\text {ns }}$ & $-0,14^{\text {ns }}$ & 0,55 \\
\hline VA $\times P G$ & 0,63 & 0,69 & 0,72 & $0,22^{\text {ns }}$ & 0,49 & 0,42 & 0,50 & 0,46 & $0,38^{\text {ns }}$ & 0,67 \\
\hline \multirow[t]{2}{*}{$\mathbf{N}$} & 33 & 42 & 36 & 36 & 38 & 40 & 30 & 38 & 24 & 42 \\
\hline & \multicolumn{10}{|c|}{ 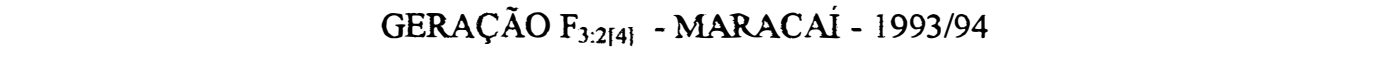 } \\
\hline NDF $\times$ APF & 0,67 & 0,82 & $0,32^{\text {ns }}$ & 0,70 & 0,75 & 0,57 & 0,56 & 0,73 & 0,65 & 0,58 \\
\hline NDF $\times$ NDM & 0,91 & 0,90 & 0,73 & 0,91 & 0,94 & 0,70 & 0,83 & 0,91 & 0,78 & 0,90 \\
\hline NDF $x$ APM & 0,64 & 0,74 & $-0,09^{\text {ns }}$ & 0,63 & 0,72 & 0,58 & 0,60 & 0,73 & $0,30^{\text {ns }}$ & 0,65 \\
\hline NDF $x$ VA & $-0,15^{\text {ns }}$ & $-0,34$ & $-0,17^{\text {ns }}$ & $0,21^{\mathrm{ns}}$ & $-0,21^{\text {ns }}$ & $-0,12^{\text {ns }}$ & $-0,18^{\text {ns }}$ & $-0,06^{\text {ns }}$ & $-0,09^{\text {ns }}$ & $0,17^{\text {ns }}$ \\
\hline NDF $x$ PG & $-0,49$ & $-0,50$ & $-0,18^{\text {ns }}$ & $-0,25^{\text {ns }}$ & $-0,48$ & $-0,39$ & $-0,17^{\text {ns }}$ & $-0,40$ & $-0,40$ & $-0,33$ \\
\hline APF x NDM & 0,61 & 0,78 & 0,58 & 0,71 & 0,72 & 0,54 & 0,68 & 0,75 & 0,49 & 0,57 \\
\hline APF $x$ APM & 0,96 & 0,93 & 0,60 & 0,96 & 0,90 & 0,91 & 0,90 & 0,97 & 0,66 & 0,96 \\
\hline APF $x$ VA & 0,35 & $0,03^{\text {ns }}$ & $0,14^{\text {ns }}$ & 0,51 & $-0,03^{\text {ns }}$ & $0,20^{\text {ns }}$ & $-0,04^{\text {ns }}$ & $0,15^{\text {ns }}$ & $-0,05^{\mathrm{ns}}$ & 0,60 \\
\hline APF $\times P G$ & $0,00^{\text {ns }}$ & $-0,13^{\text {ns }}$ & $0,13^{\text {ns }}$ & $0,13^{\text {ns }}$ & $-0,06^{\text {ns }}$ & $0,02^{\text {ns }}$ & $0,14^{\text {ns }}$ & $-0,12^{n \mathrm{ss}}$ & $0,03^{\text {ns }}$ & $0,20^{\text {ns }}$ \\
\hline NDM $\times$ APM & 0,61 & 0,73 & 0,39 & 0,63 & 0,72 & 0,66 & 0,75 & 0,79 & $0,22^{\text {ns }}$ & 0,66 \\
\hline NDM $\times$ VA & $-0,20^{\text {ns }}$ & $-0,35$ & $-0,21^{\text {ns }}$ & $0,15^{n s}$ & $-0,22^{\text {ns }}$ & $-0,35$ & $-0,28^{\mathrm{ns}}$ & $0,03^{\mathrm{ns}}$ & $0,13^{\mathrm{ns}}$ & $0,22^{\mathrm{ns}}$ \\
\hline NDM $x$ PG & $-0,49$ & $-0,51$ & $-0,08^{\text {ns }}$ & $-0,27^{n s}$ & $-0,49$ & $-0,47$ & $-0,18^{\text {ns }}$ & $-0,36$ & $-0,44$ & $-0,16^{\text {ns }}$ \\
\hline APM $\times$ VA & $0,30^{\text {ns }}$ & $0,08^{\text {ns }}$ & $-0,23^{\text {ns }}$ & 0,59 & $0,11^{\mathrm{ns}}$ & $0,13^{\text {ns }}$ & $0,06^{\mathrm{ns}}$ & $0,19^{n s}$ & $-0,05^{\text {ns }}$ & 0,56 \\
\hline APM $\times$ PG & $-0,07^{\text {ns }}$ & $-0,07^{n s}$ & $0,03^{\text {ns }}$ & $0,19^{\text {ns }}$ & $-0,09^{n s}$ & $-0,02^{n s}$ & $0,22^{\text {ns }}$ & $-0,10^{\text {ns }}$ & $0,18^{\mathrm{ns}}$ & $0,19^{\text {ns }}$ \\
\hline VA $x$ PG & 0,65 & 0,67 & 0,60 & 0,55 & 0,52 & 0,75 & 0,68 & 0,61 & $0,28^{\text {ns }}$ & 0,68 \\
\hline $\mathrm{N}$ & 40 & 35 & 33 & 38 & 40 & 36 & 33 & 37 & 35 & 35 \\
\hline
\end{tabular}

${ }^{1}$ Para identificação dos caracteres, consultar o Apêndice 1.

${ }^{2}$ Para identificação dos cruzamentos que deram origem à estas progênies, consultar o Apêndice 6.

${ }^{n s}$ Não Significativo. As correlações não assinaladas são todas significativas $(P \leq 0,05)$. 
Tabela 30 CONTINUAÇÃO...

CARACTERES ${ }^{1}$

POPULAÇÕES ${ }^{2}$

\begin{tabular}{llllllllll}
11 & 12 & 13 & 14 & 15 & 16 & 17 & 18 & 19 & 20 \\
\hline
\end{tabular}

GERAÇÃO $F_{2[4]}$ - PIRACICABA -1992/93

$\begin{array}{lllllllllll}\text { NDF x APF } & 0,69 & 0,89 & 0,80 & 0,86 & 0,77 & 0,89 & 0,67 & 0,61 & 0,55 & 0,48 \\ \text { NDF x NDM } & 0,85 & 0,83 & 0,78 & 0,90 & 0,30^{\text {ns }} & 0,88 & 0,83 & 0,42 & 0,77 & 0,66 \\ \text { NDF x APM } & 0,48 & 0,85 & 0,69 & 0,78 & 0,34 & 0,81 & 0,63 & 0,27^{\text {ns }} & 0,55 & 0,42 \\ \text { NDF x VA } & 0,44 & 0,49 & 0,21^{\text {ns }} & 0,68 & 0,19^{\text {ns }} & 0,31^{\text {ns }} & 0,15^{\text {ns }} & 0,08^{\text {ns }} & 0,45 & 0,48 \\ \text { NDF x PG } & 0,23^{\text {ns }} & 0,12^{\text {ns }} & 0,00^{\text {ns }} & -0,03^{\text {ns }} & 0,06^{\text {ns }} & -0,03^{\text {ns }} & 0,06^{\text {ns }} & 0,13^{\text {ns }} & 0,35 & 0,09^{\text {ns }} \\ \text { APF x NDM } & 0,60 & 0,79 & 0,62 & 0,66 & 0,12^{\text {ns }} & 0,75 & 0,75 & 0,30^{\text {ns }} & 0,43 & 0,29^{\text {ns }} \\ \text { APF x APM } & 0,64 & 0,93 & 0,67 & 0,91 & 0,46 & 0,81 & 0,92 & 0,38 & 0,68 & 0,68 \\ \text { APF x VA } & 0,45 & 0,48 & 0,37 & 0,73 & 0,09^{\text {ns }} & 0,23^{\text {ns }} & 0,50 & 0,25^{\text {ns }} & 0,41 & 0,49 \\ \text { APF x PG } & 0,39 & 0,17^{\text {ns }} & 0,07^{\text {ns }} & 0,10^{\text {ns }} & 0,02^{\text {ns }} & -0,08^{\text {ns }} & 0,16^{\text {ns }} & 0,19^{\text {ns }} & 0,62 & 0,41 \\ \text { NDM x APM } & 0,55 & 0,77 & 0,74 & 0,64 & 0,44 & 0,78 & 0,81 & 0,22^{\text {ns }} & 0,56 & 0,40 \\ \text { NDM x VA } & 0,57 & 0,51 & 0,35 & 0,58 & 0,48 & 0,31^{\text {ns }} & 0,27^{\text {ns }} & -0,05^{\text {ns }} & 0,61 & 0,56 \\ \text { NDM x PG } & 0,32 & 0,21^{\text {ns }} & 0,00^{\text {ns }} & 0,00^{\text {ns }} & 0,32 & -0,02^{\text {ns }} & 0,10^{\text {ns }} & 0,01^{\text {ns }} & 0,30^{\text {ns }} & 0,38 \\ \text { APM x VA } & 0,51 & 0,53 & 0,24^{\text {ns }} & 0,79 & 0,41 & 0,38 & 0,51 & 0,29^{\text {ns }} & 0,49 & 0,55 \\ \text { APM x PG } & 0,31 & 0,29^{\text {ns }} & 0,06^{\text {ns }} & 0,32^{\text {ns }} & 0,29^{\text {ns }} & 0,02^{\text {ns }} & 0,08^{\text {ns }} & 0,15^{\text {ns }} & 0,56 & 0,57 \\ \text { VA x PG } & 0,66 & 0,72 & 0,57 & 0,28^{\text {ns }} & 0,68 & 0,50 & 0,53 & 0,64 & 0,55 & 0,52 \\ \quad \text { N } & 45 & 38 & 37 & 23 & 41 & 36 & 26 & 39 & 38 & 42\end{array}$

GERAÇÃO $F_{3: 214]}$ - MARACAÍ - 1993/94

\begin{tabular}{lllllllllll} 
NDF x APF & 0,58 & 0,74 & 0,64 & 0,60 & 0,42 & 0,58 & 0,78 & 0,55 & $0,21^{\text {ns }}$ & 0,51 \\
NDF x NDM & 0,83 & 0,86 & 0,85 & 0,72 & 0,88 & 0,91 & 0,82 & 0,47 & 0,60 & 0,78 \\
NDF x APM & 0,31 & 0,75 & 0,52 & 0,68 & $0,26^{\text {ns }}$ & 0,62 & 0,78 & $0,21^{\text {ns }}$ & $0,11^{\text {ns }}$ & 0,51 \\
NDF x VA & $-0,20^{\text {ns }}$ & $-0,12^{\text {ns }}$ & $0,12^{\text {ns }}$ & $0,21^{\text {ns }}$ & $-0,30^{\text {ns }}$ & $-0,31$ & $-0,20^{\text {ns }}$ & $-0,20^{\text {ns }}$ & $-0,31$ & 0,40 \\
NDF x PG & $-0,29^{\text {ss }}$ & $-0,35$ & $-0,08^{\text {ns }}$ & $0,07^{\text {ns }}$ & $-0,39$ & $-0,27^{\text {ns }}$ & $-0,42$ & $-0,28^{\text {ns }}$ & $-0,37$ & $0,23^{\text {ns }}$ \\
APF x NDM & 0,52 & 0,70 & 0,54 & 0,52 & $0,31^{\text {ns }}$ & 0,53 & 0,61 & 0,30 & 0,45 & 0,41 \\
APF x APM & 0,80 & 0,93 & 0,78 & 0,94 & 0,75 & 0,96 & 0,93 & 0,53 & 0,83 & 0,96 \\
APF x VA & $0,23^{\text {ns }}$ & $0,06^{\text {ns }}$ & 0,38 & 0,52 & $0,18^{\text {ns }}$ & $0,17^{\text {ns }}$ & $0,12^{\text {ns }}$ & $0,11^{\text {ns }}$ & $0,01^{\text {ns }}$ & 0,34 \\
APF x PG & $0,23^{\text {ns }}$ & $-0,08^{\text {ns }}$ & 0,33 & 0,46 & $-0,09^{\text {ns }}$ & 0,36 & $-0,04^{\text {ns }}$ & $-0,02^{\text {ss }}$ & $0,27^{\text {ns }}$ & 0,36 \\
NDM x APM & 0,33 & 0,68 & 0,65 & 0,59 & $0,29^{\text {ns }}$ & 0,59 & 0,67 & 0,46 & 0,39 & 0,38 \\
NDM x VA & $-0,15^{\text {ns }}$ & $-0,09^{\text {ns }}$ & $-0,06^{\text {ns }}$ & $0,00^{\text {ns }}$ & $-0,23^{\text {ns }}$ & $-0,25^{\text {ns }}$ & $-0,14^{\text {ns }}$ & $-0,10^{\text {ns }}$ & $-0,19^{\text {ns }}$ & 0,35 \\
NDM x PG & $-0,12^{\text {ns }}$ & $-0,36$ & $-0,08^{\text {ns }}$ & $0,12^{\text {ns }}$ & $-0,36$ & $-0,30^{\text {ns }}$ & $-0,47$ & $-0,05^{\text {ns }}$ & $-0,22^{\text {ns }}$ & $0,05^{\text {ns }}$ \\
APM x VA & 0,42 & $0,08^{\text {ns }}$ & $0,23^{\text {ns }}$ & 0,52 & 0,33 & $0,18^{\text {ns }}$ & $0,12^{\text {ns }}$ & $0,06^{\text {ns }}$ & $0,28^{\text {ss }}$ & 0,36 \\
APM x PG & 0,44 & $-0,07^{\text {ns }}$ & $0,26^{\text {ss }}$ & 0,50 & $0,06^{\text {ns }}$ & 0,34 & $0,02^{\text {ns }}$ & $0,28^{\text {ns }}$ & $0,23^{\text {ns }}$ & 0,39 \\
VA x PG & 0,77 & 0,74 & 0,60 & 0,68 & 0,65 & 0,70 & 0,73 & 0,59 & 0,49 & 0,60 \\
\multicolumn{1}{c}{ N } & 40 & 41 & 42 & 42 & 35 & 41 & 36 & 41 & 46 & 38 \\
\hline
\end{tabular}

${ }^{1}$ Para identificação dos caracteres, consultar o Apêndice 1.

${ }^{2}$ Para identificação dos cruzamentos que deram origem à estas populações, consultar o Apêndice 6 .

${ }^{n s}$ Não Significativo. As correlações não assinaladas são todas significativas $(P \leq 0,05)$.

Continua... 
Tabela 30 CONTINUAÇÃO...

\begin{tabular}{|c|c|c|c|c|c|c|c|c|c|c|}
\hline \multirow{2}{*}{ CARACTERES $^{1}$} & \multicolumn{10}{|c|}{ POPULAÇÕES ${ }^{2}$} \\
\hline & 21 & 22 & 23 & 24 & 25 & 26 & 27 & 28 & 29 & 30 \\
\hline & & \multicolumn{9}{|c|}{ GERAÇÃO $F_{2|4|}$ - PIRACICABA -1992/93 } \\
\hline NDF $\times$ APF & 0,83 & 0,73 & 0,78 & 0,65 & 0,72 & 0,80 & 0,84 & 0,75 & 0,75 & 0,48 \\
\hline NDF $\times$ NDM & 0,93 & 0,75 & 0,75 & 0,51 & 0,72 & 0,43 & 0,87 & 0,73 & 0,68 & 0,46 \\
\hline NDF $\times$ APM & 0,72 & 0,64 & 0,71 & 0,64 & 0,54 & 0,54 & 0,63 & 0,67 & 0,41 & 0,44 \\
\hline NDF $\times$ VA & 0,60 & 0,47 & 0,41 & 0,45 & 0,37 & $0,10^{\text {ns }}$ & $0,26^{\mathrm{ns}}$ & $0,28^{\mathrm{ns}}$ & 0,48 & $0,14^{\text {ns }}$ \\
\hline NDF $\times$ PG & 0,38 & $-0,05^{\text {ns }}$ & $0,15^{\text {ns }}$ & 0,30 & $0,18^{\text {ns }}$ & $-0,12^{\text {ns }}$ & $0,09^{\text {ns }}$ & $0,17^{\mathrm{ns}}$ & $0,19^{\text {ns }}$ & $0,08^{\text {ns }}$ \\
\hline APF $\times$ NDM & 0,82 & 0,64 & 0,73 & $0,28^{\text {ns }}$ & 0,52 & 0,29 & 0,73 & 0,48 & 0,59 & 0,38 \\
\hline APF $\times$ APM & 0,75 & 0,79 & 0,83 & 0,53 & 0,63 & 0,58 & 0,78 & 0,67 & 0,44 & 0,52 \\
\hline APF $x$ VA & 0,61 & 0,35 & $0,12^{\text {ns }}$ & 0,34 & 0,36 & $0,23^{\text {ns }}$ & 0,51 & 0,30 & 0,41 & $0,08^{\text {ns }}$ \\
\hline $\mathrm{APF} \times \mathrm{PG}$ & 0,43 & $0,07^{\mathrm{ns}}$ & $-0,03^{\text {ns }}$ & 0,30 & $0,16^{\mathrm{ns}}$ & $0,04^{\mathrm{ns}}$ & 0,34 & $0,25^{\text {ns }}$ & $0,24^{\text {ns }}$ & $0,14^{\text {ns }}$ \\
\hline NDM $\times$ APM & 0,76 & 0,63 & 0,76 & 0,30 & 0,48 & 0,54 & 0,51 & 0,59 & 0,44 & $0,25^{\text {ns }}$ \\
\hline NDM x VA & 0,60 & 0,53 & $0,12^{\mathrm{ns}}$ & $0,19^{\text {ns }}$ & 0,50 & $-0,11^{\text {ns }}$ & $0,13^{\text {ns }}$ & 0,35 & 0,44 & $0,24^{\text {ns }}$ \\
\hline NDM $\times$ PG & 0,46 & 0,31 & $-0,06^{\mathrm{ns}}$ & $0,07^{\text {ns }}$ & $0,08^{\text {ns }}$ & $-0,16^{\mathrm{ns}}$ & $-0,01^{\mathrm{ns}}$ & 0,33 & $0,06^{\mathrm{ns}}$ & $0,22^{\text {ns }}$ \\
\hline APM $x$ VA & 0,65 & 0,51 & $0,21^{\text {ns }}$ & 0,41 & 0,60 & $-0,02^{\text {ns }}$ & 0,36 & 0,41 & 0,57 & 0,42 \\
\hline $\mathrm{APM} \times \mathrm{PG}$ & 0,53 & $0,16^{\mathrm{ns}}$ & $0,09^{\text {ns }}$ & 0,43 & 0,49 & $-0,02^{\text {ns }}$ & 0,40 & $0,22^{\text {ns }}$ & 0,43 & 0,35 \\
\hline VA $x$ PG & 0,63 & 0,45 & 0,73 & 0,62 & 0,57 & 0,69 & 0,76 & 0,50 & 0,57 & 0,56 \\
\hline $\mathrm{N}$ & 37 & 42 & 40 & 43 & 35 & 44 & 41 & 43 & 40 & 42 \\
\hline
\end{tabular}

GERAÇÃO F $F_{3: 2[4]}$ - MARACAÍ - 1993/94

\begin{tabular}{lllllllllll} 
NDF x APF & 0,84 & 0,60 & 0,36 & 0,65 & 0,77 & 0,50 & 0,73 & 0,66 & 0,56 & 0,72 \\
NDF x NDM & 0,91 & 0,77 & 0,76 & 0,76 & 0,73 & 0,52 & 0,74 & 0,77 & 0,66 & 0,71 \\
NDF x APM & 0,83 & 0,47 & $0,28^{\text {ns }}$ & 0,47 & 0,75 & 0,54 & 0,67 & 0,59 & 0,48 & $0,26^{\text {ns }}$ \\
NDF x VA & $-0,06^{\text {ns }}$ & $0,21^{\text {ns }}$ & $-0,17^{\text {ns }}$ & $-0,07^{\text {ns }}$ & $-0,25^{\text {ns }}$ & $-0,19^{\text {ns }}$ & 0,34 & $-0,21^{\text {ns }}$ & $0,11^{\text {ns }}$ & $-0,11^{\text {ns }}$ \\
NDF x PG & $-0,04^{\text {ns }}$ & $0,08^{\text {ns }}$ & $-0,01^{\text {ns }}$ & $-0,04^{\text {ns }}$ & $-0,41$ & $-0,20^{\text {ns }}$ & $0,19^{\text {ns }}$ & $-0,24^{\text {ns }}$ & $-0,03^{\text {ns }}$ & $0,01^{\text {ns }}$ \\
APF x NDM & 0,83 & 0,49 & $0,28^{\text {ns }}$ & 0,54 & 0,67 & 0,35 & 0,64 & 0,69 & 0,61 & 0,57 \\
APF x APM & 0,96 & 0,89 & 0,88 & 0,83 & 0,80 & 0,79 & 0,95 & 0,87 & 0,77 & 0,45 \\
APF x VA & $0,19^{\text {ns }}$ & 0,69 & $-0,04^{\text {ns }}$ & $0,01^{\text {ns }}$ & $-0,13^{\text {ns }}$ & 0,34 & 0,60 & $0,01^{\text {ns }}$ & $0,00^{\text {ns }}$ & 0,34 \\
APF x PG & $0,20^{\text {ns }}$ & 0,48 & $0,21^{\text {ns }}$ & $0,25^{\text {ns }}$ & $-0,25^{\text {ns }}$ & 0,53 & 0,52 & $0,00^{\text {ns }}$ & $0,18^{\text {ns }}$ & 0,44 \\
NDM x APM & 0,82 & 0,44 & $0,25^{\text {ns }}$ & 0,48 & 0,74 & 0,60 & 0,60 & 0,73 & 0,62 & 0,45 \\
NDM x VA & $0,04^{\text {ns }}$ & $0,22^{\text {ns }}$ & $-0,16^{\text {ns }}$ & $-0,21^{\text {ns }}$ & $-0,25^{\text {ns }}$ & $-0,11^{\text {ns }}$ & $0,22^{\text {ns }}$ & $-0,24^{\text {ns }}$ & $0,04^{\text {ns }}$ & $0,10^{\text {ns }}$ \\
NDM x PG & $0,03^{\text {ns }}$ & $0,08^{\text {ns }}$ & $0,01^{\text {ns }}$ & $-0,01^{\text {ns }}$ & $-0,41$ & $-0,04^{\text {ns }}$ & $0,15^{\text {ns }}$ & $-0,17^{\text {ns }}$ & $0,20^{\text {ns }}$ & $0,20^{\text {ns }}$ \\
APM x VA & $0,18^{\text {ns }}$ & 0,69 & $-0,03^{\text {ns }}$ & $-0,16^{\text {ns }}$ & $-0,07^{\text {ns }}$ & $0,23^{\text {ns }}$ & 0,64 & $-0,03^{\text {ns }}$ & 0,33 & 0,60 \\
APM x PG & $0,17^{\text {ns }}$ & 0,52 & $0,07^{\text {ns }}$ & $0,16^{\text {ns }}$ & $-0,26^{\text {ns }}$ & $0,30^{\text {ns }}$ & 0,57 & $-0,04^{\text {ns }}$ & 0,46 & 0,34 \\
VA x PG & 0,82 & 0,72 & 0,55 & 0,50 & 0,62 & 0,57 & 0,83 & 0,68 & 0,49 & 0,67 \\
\multicolumn{1}{c}{ N } & 0,59 & 39 & 36 & 37 & 36 & 35 & 41 & 41 & 38 & 40 \\
\hline
\end{tabular}

${ }^{1}$ Para identificação dos caracteres, consultar o Apêndice 1.

${ }^{2}$ Para identificação dos cruzamentos que deram origem à estas populações, consultar o Apêndice 6.

${ }^{n s}$ Não Significativo. As correlações não assinaladas são todas significativas $(P \leq 0,05)$. 
Tabela 30 CONTINUAÇÃO...

\begin{tabular}{|c|c|c|c|c|c|c|c|c|c|c|}
\hline \multirow[t]{2}{*}{ CARACTERES } & \multicolumn{10}{|c|}{ POPULAÇÕES ${ }^{2}$} \\
\hline & 31 & 32 & 33 & 34 & 35 & 36 & 37 & 38 & 39 & 40 \\
\hline & & \multicolumn{9}{|c|}{ GERAÇÃO F ${ }_{2[4]}$ - PIRACICABA -1992/93 } \\
\hline NDF $\times$ APF & 0,50 & 0,87 & 0,79 & 0,31 & 0,78 & 0,88 & 0,92 & 0,80 & 0,49 & 0,79 \\
\hline NDF $\times$ NDM & 0,74 & 0.87 & 0,81 & $0,29^{\text {ns }}$ & 0,83 & 0,82 & 0,93 & 0,90 & 0,78 & 0.83 \\
\hline NDF $\times A P M$ & 0,40 & 0,65 & 0,46 & $-0,02^{\text {ns }}$ & 0,39 & 0,83 & 0,85 & 0,78 & 0,41 & 0,49 \\
\hline NDF $\times$ VA & $0,20^{\text {ns }}$ & 0,51 & $0,30^{\text {ns }}$ & $0,23^{\text {ns }}$ & 0,48 & 0,31 & 0,33 & 0,51 & 0,45 & $0,16^{\mathrm{ns}}$ \\
\hline NDF $x$ PG & $0,21^{\text {ns }}$ & $-0,14^{\text {ns }}$ & $0,01^{\text {ns }}$ & $0,01^{\text {ns }}$ & 0,36 & $-0,11^{\mathrm{ns}}$ & $-0,48$ & $0,16^{n s}$ & $0,14^{\text {ns }}$ & $0,03^{\text {ns }}$ \\
\hline$A P F \times N D M$ & 0,46 & 0,79 & 0,61 & 0,37 & 0,72 & 0,73 & 0,84 & 0,74 & 0,63 & 0,70 \\
\hline APF $x$ APM & 0,64 & 0,75 & 0,50 & 0,57 & 0,53 & 0,91 & 0,90 & 0,82 & 0,65 & 0,69 \\
\hline $\mathrm{APF} \times \mathrm{VA}$ & $0,27^{\text {ns }}$ & 0,63 & $0,25^{\text {ns }}$ & 0,41 & 0,60 & 0,35 & $0,28^{\mathrm{ns}}$ & 0,36 & 0,58 & $0,22^{\text {ns }}$ \\
\hline APF $\times$ PG & $0,13^{\text {ns }}$ & $0,00^{\text {ns }}$ & $0,05^{\text {ns }}$ & 0,33 & 0,36 & $-0,11^{\text {ns }}$ & $-0,46$ & $0,14^{\text {ns }}$ & $0,26^{n s}$ & $0,16^{\mathrm{ns}}$ \\
\hline NDM $\times$ APM & 0,36 & 0,47 & 0,39 & 0,47 & 0,49 & 0,70 & 0,81 & 0,75 & 0,54 & 0,56 \\
\hline NDM $x$ VA & $0,26^{\text {ns }}$ & 0,47 & $0,15^{\text {ns }}$ & 0,36 & 0,50 & $0,26^{\mathrm{ns}}$ & 0,33 & 0,54 & 0,63 & 0,36 \\
\hline$N D M \times P G$ & 0,33 & $-0,36$ & $0,01^{\text {ns }}$ & $0,24^{\text {ns }}$ & $0,24^{\text {ns }}$ & $-0,22^{\text {ns }}$ & $-0,53$ & $0,15^{\mathrm{ns}}$ & 0,33 & $0,24^{\text {ns }}$ \\
\hline APM $x$ VA & 0,41 & 0,53 & $0,28^{\text {ns }}$ & 0,51 & 0,37 & 0,53 & 0,47 & 0,60 & 0,55 & 0,40 \\
\hline$A P M \times P G$ & 0,40 & $0,22^{\text {ns }}$ & 0,38 & 0,50 & 0,31 & $0,13^{\text {ns }}$ & $-0,37$ & 0,31 & $0,22^{\text {ns }}$ & 0,51 \\
\hline$V A \times P G$ & 0,71 & 0,37 & 0,67 & 0,68 & 0,75 & 0,44 & $0,27^{n s}$ & 0,44 & 0,62 & 0,64 \\
\hline \multirow[t]{2}{*}{$\mathrm{N}$} & 38 & 42 & 39 & 40 & 43 & 44 & 40 & 40 & 41 & 42 \\
\hline & \multicolumn{10}{|c|}{ GERAÇÃO F $3: 2[4]$ - MARACAÍ - 1993/94 } \\
\hline NDF $x$ APF & $0,22^{\text {ns }}$ & 0,83 & 0,66 & 0,41 & 0,44 & 0,89 & 0,89 & 0,64 & 0,80 & 0,57 \\
\hline NDF $\times$ NDM & 0,78 & 0,89 & 0,81 & 0,39 & 0,73 & 0,93 & 0,97 & 0,92 & 0,77 & 0,68 \\
\hline NDF $\times A P M$ & $0,24^{\text {ns }}$ & 0,78 & 0,59 & $0,08^{\text {ns }}$ & $0,29^{\text {ns }}$ & 0,85 & 0,89 & 0,58 & 0,77 & 0,34 \\
\hline NDF $x$ VA & $-0,22^{\text {ns }}$ & $0,24^{\text {ns }}$ & $0,02^{\text {ns }}$ & $-0,05^{n s}$ & $0,15^{\text {ns }}$ & $0,19^{\text {ns }}$ & $0,10^{\text {ns }}$ & 0,37 & $0,20^{\text {ns }}$ & $0,12^{\text {ns }}$ \\
\hline NDF $\times$ PG & $-0,25^{\mathrm{ns}}$ & $0,01^{\mathrm{ns}}$ & $0,04^{\text {ns }}$ & $-0,07^{\text {ns }}$ & $0,03^{\text {ns }}$ & $0,08^{\text {ns }}$ & $-0,16^{\text {ns }}$ & 0,40 & $0,24^{\text {ns }}$ & $-0,05^{\text {ns }}$ \\
\hline APF $\times$ NDM & $0,14^{\text {ns }}$ & 0,69 & 0,46 & 0,46 & $0,27^{\text {ns }}$ & 0,82 & 0,91 & 0,62 & 0,68 & 0,43 \\
\hline APF $\times$ APM & 0,82 & 0,90 & 0,81 & 0,65 & 0,77 & 0,98 & 0,97 & 0,94 & 0,92 & 0,86 \\
\hline APF x VA & $0,08^{\text {ns }}$ & 0,55 & $0,25^{\text {ns }}$ & $0,11^{\text {ns }}$ & 0,64 & $0,32^{\text {ns }}$ & 0,34 & 0,57 & $0,24^{\text {ns }}$ & 0,39 \\
\hline APF $\times$ PG & $0,26^{\text {ns }}$ & $0,26^{\mathrm{ns}}$ & $0,30^{\text {ns }}$ & $0,19^{\text {ns }}$ & 0,63 & $0,29^{\text {ns }}$ & $0,06^{\mathrm{ns}}$ & 0,64 & $0,21^{\text {ns }}$ & $0,21^{\text {ns }}$ \\
\hline NDM $\times$ APM & $0,09^{\text {ns }}$ & 0,63 & 0,48 & 0,45 & $0,23^{\text {ns }}$ & 0,77 & 0,91 & 0,57 & 0,75 & 0,40 \\
\hline NDM x VA & $-0,48$ & $0,13^{\text {ns }}$ & $-0,08^{\text {ns }}$ & $-0,30$ & $-0,02^{\mathrm{ns}}$ & $0,10^{\text {ns }}$ & $0,18^{\text {ns }}$ & 0,36 & $0,23^{\text {ns }}$ & $0,11^{\text {ns }}$ \\
\hline NDM x PG & $-0,20^{\text {ns }}$ & $0,00^{\text {ns }}$ & $0,02^{\mathrm{ns}}$ & $-0,21^{\mathrm{ns}}$ & $-0,10^{\text {ns }}$ & $0,12^{\text {ns }}$ & $-0,13^{\text {ns }}$ & 0,41 & $0,17^{\text {ns }}$ & $-0,25^{n s}$ \\
\hline APM x VA & $0,27^{\text {ns }}$ & 0,59 & 0,33 & $0,09^{\text {ns }}$ & 0,61 & 0,33 & 0,33 & 0,68 & $0,27^{\text {ns }}$ & 0,33 \\
\hline APM $\times$ PG & $0,33^{\text {ns }}$ & 0,39 & 0,49 & $0,08^{\text {ns }}$ & 0,64 & 0,32 & $0,07^{\text {ns }}$ & 0,78 & $0,22^{\text {ns }}$ & $0,26^{n s}$ \\
\hline VA $x$ PG & 0,54 & 0,73 & 0,65 & 0,64 & 0,72 & 0,50 & 0,54 & 0,78 & 0,73 & 0,49 \\
\hline $\mathrm{N}$ & 30 & 42 & 41 & 42 & 42 & 36 & 36 & 43 & 33 & 44 \\
\hline
\end{tabular}

${ }^{1}$ Para identificação dos caracteres, consultar o Apêndice 1.

${ }^{2}$ Para identificação dos cruzamentos que deram origem à estas progênies, consultar o Apêndice 6.

${ }^{n s}$ Não Significativo. As correlações não assinaladas são todas significativas $(P \leq 0,05)$. 
Tabela 30 CONTINUAÇÃO...

\begin{tabular}{|c|c|c|c|c|c|c|c|c|c|}
\hline \multirow[t]{2}{*}{ CARACTERES $^{1}$} & \multicolumn{5}{|c|}{ POPULAÇÕES ${ }^{2}$} & \multicolumn{4}{|c|}{ TESTEMUNHAS } \\
\hline & 41 & 42 & 43 & 44 & 45 & Cristalina & IAC-8 & E. $-301^{2}$ & SS-1 \\
\hline & & \multicolumn{4}{|c|}{ GERAÇÃO $F_{2[4]}$} & \multicolumn{4}{|c|}{ PIRACICABA -1992/93 } \\
\hline NDF $\times$ APF & 0,71 & 0,62 & 0,67 & 0,78 & 0,65 & 0,44 & $0,30^{\text {ns }}$ & 0,58 & $-0,08^{\text {ns }}$ \\
\hline NDF $\times$ NDM & 0,84 & 0,72 & 0,73 & 0,84 & 0,33 & $0,25^{\text {ns }}$ & 0,45 & 0,46 & 0,47 \\
\hline NDF x APM & 0,40 & 0,51 & $0,29^{\text {ns }}$ & 0,70 & $0,27^{\mathrm{ns}}$ & $0,08^{\text {ns }}$ & $0,21^{\text {ns }}$ & 0,39 & $-0,05^{\text {ns }}$ \\
\hline NDF $x$ VA & 0,41 & 0,57 & $0,15^{\text {ns }}$ & 0,37 & $0,22^{\text {ns }}$ & 0,29 & $-0,06^{\text {ns }}$ & $-0,04^{\text {ns }}$ & $-0,11^{\text {ns }}$ \\
\hline NDF $\times$ PG & $0,09^{\text {ns }}$ & $0,28^{\text {ns }}$ & 0,37 & $0,00^{\text {ns }}$ & $-0,08^{n s}$ & $0,26^{\text {ns }}$ & $-0,03^{\text {ns }}$ & $-0,05^{\text {ns }}$ & $0,26^{\text {ns }}$ \\
\hline APF $\times$ NDM & 0,60 & 0,49 & $0,25^{\text {ns }}$ & 0,71 & 0,41 & $0,12^{\text {ns }}$ & $0,04^{\text {ns }}$ & 0,35 & $0,02^{\text {ns }}$ \\
\hline APF $x$ APM & 0,65 & 0,68 & 0,48 & 0,75 & 0,44 & 0,49 & 0,65 & 0,80 & 0,61 \\
\hline APF $\times$ VA & 0,30 & 0,51 & $0,21^{\text {ns }}$ & 0,30 & 0,34 & 0,35 & $0,06^{\text {ns }}$ & 0,42 & $0,08^{\text {ns }}$ \\
\hline APF $\times P G$ & $0,27^{\text {ns }}$ & 0,43 & 0,40 & $0,00^{\text {ns }}$ & $0,17^{\text {ns }}$ & 0,34 & $0,09^{\text {ns }}$ & $0,11^{\text {ns }}$ & $0,19^{\text {rs }}$ \\
\hline NDM $\times$ APM & 0,30 & 0,60 & $0,09^{\text {ns }}$ & 0,57 & 0,31 & $0,09^{\text {ns }}$ & $0,28^{\text {ns }}$ & $0,27^{\text {ns }}$ & $-0,02^{\text {ns }}$ \\
\hline NDM $\times$ VA & 0,62 & 0,55 & $0,04^{\mathrm{ns}}$ & $0,15^{\text {ns }}$ & 0,39 & $0,05^{\text {ns }}$ & 0,50 & $-0,18^{\mathrm{ns}}$ & $-0,16^{\mathrm{ns}}$ \\
\hline NDM $\times$ PG & $0,21^{\text {ns }}$ & $0,23^{\text {ns }}$ & $0,16^{\text {ns }}$ & $-0,27^{\text {ns }}$ & $0,13^{\text {ns }}$ & $0,07^{\text {ns }}$ & $0,41^{\text {ns }}$ & $-0,24^{n s}$ & $0,09^{\text {ns }}$ \\
\hline APM $\times$ VA & $0,29^{\text {ns }}$ & 0,62 & 0,35 & 0,35 & 0,46 & 0,45 & $0,26^{\mathrm{ns}}$ & 0,54 & 0,42 \\
\hline APM $\times$ PG & 0,31 & 0,43 & 0,37 & $0,13^{\text {ns }}$ & $0,25^{\text {ns }}$ & $0,16^{\text {ns }}$ & $0,33^{\text {ns }}$ & $0,12^{\text {ns }}$ & 0,39 \\
\hline VA $x$ PG & 0,45 & 0,55 & 0,64 & 0,57 & 0,60 & $0,22^{\text {ns }}$ & 0,58 & $0,35^{\text {ns }}$ & $0,18^{\text {ns }}$ \\
\hline \multirow[t]{2}{*}{$\mathrm{N}$} & 42 & 42 & 38 & 42 & 42 & 45 & 38 & 36 & 41 \\
\hline & & \multicolumn{4}{|c|}{ GERAÇÃO $F_{3: 2\lceil 4 \mid}$} & \multicolumn{4}{|c|}{ MARACAÍ - 1993/94 } \\
\hline NDF $\times$ APF & 0,86 & 0,80 & 0,42 & 0,75 & $0,20^{\text {ns }}$ & $-0,22^{\text {ns }}$ & $-0,11^{\text {ns }}$ & $0,34^{\text {ns }}$ & $-0,29^{\text {ns }}$ \\
\hline NDF $\times$ NDM & 0,78 & 0,88 & 0,67 & 0,84 & 0,62 & $0,31^{\text {ns }}$ & 0,66 & 0,45 & $-0,11^{\mathrm{ns}}$ \\
\hline NDF $\times$ APM & 0,68 & 0,71 & $0,22^{\mathrm{ns}}$ & 0,50 & $0,06^{n s}$ & $-0,48$ & $-0,07^{\text {ns }}$ & $0,24^{\text {ns }}$ & $-0,18^{\text {ns }}$ \\
\hline NDF x VA & 0,37 & 0,33 & $-0,18^{\mathrm{ns}}$ & $-0,16^{\text {ns }}$ & $-0,08^{\text {ns }}$ & $-0,48$ & $0,17^{\text {ns }}$ & $-0,14^{\mathrm{ms}}$ & $-0,22^{\mathrm{ns}}$ \\
\hline NDF $\times$ PG & 0,46 & $0,21^{\text {ns }}$ & $-0,45$ & $-0,26^{\text {ns }}$ & $-0,16^{\text {ns }}$ & $-0,31^{\text {ns }}$ & $0,07^{\text {ns }}$ & $0,18^{\text {ns }}$ & $-0,57$ \\
\hline APF $\times$ NDM & 0,69 & 0,73 & 0,37 & 0,71 & $0,17^{\text {ns }}$ & $-0,54$ & $-0,04^{\text {ns }}$ & 0,41 & $0,29^{\text {ns }}$ \\
\hline APF $\times$ APM & 0,71 & 0,91 & 0,52 & 0,77 & 0,59 & 0,86 & 0,76 & 0,88 & 0,81 \\
\hline APF $\times$ VA & 0,42 & 0,54 & $0,18^{\text {rs }}$ & $0,02^{\text {ns }}$ & 0,65 & 0,40 & $0,21^{\text {ns }}$ & $0,17^{\text {ns }}$ & 0,64 \\
\hline APF $\times P G$ & 0,50 & 0,43 & $0,05^{\text {ns }}$ & $-0,10^{\text {ns }}$ & 0,61 & 0,43 & $0,29^{\text {ns }}$ & $0,23^{\text {ns }}$ & 0,36 \\
\hline NDM $\times$ APM & 0,43 & 0,67 & 0,39 & 0,54 & 0,32 & $-0,44$ & $-0,08^{\text {ns }}$ & 0,36 & $0,26^{\text {ns }}$ \\
\hline NDM $\times$ VA & $0,27^{\mathrm{ns}}$ & $0,23^{n s}$ & $-0,19^{\text {ns }}$ & $-0,28^{n s}$ & $-0,08^{\text {ns }}$ & $-0,25^{\text {ns }}$ & 0,40 & $-0,57$ & 0,34 \\
\hline NDM $\times$ PG & $0,22^{\mathrm{ns}}$ & $0,15^{\text {ns }}$ & $-0,31$ & $-0,36$ & $0,11^{\text {ns }}$ & $-0,25^{\text {ns }}$ & 0,39 & $0,13^{\text {ns }}$ & $0,03^{\text {ns }}$ \\
\hline APM $\times$ VA & 0,58 & 0,52 & $0,22^{\mathrm{ns}}$ & $0,14^{\text {ns }}$ & 0,54 & 0,58 & 0,33 & $0,24^{\text {ns }}$ & 0,66 \\
\hline APM $\times$ PG & 0,53 & 0,40 & $0,19^{\text {ns }}$ & $0,00^{\mathrm{ns}}$ & 0,43 & 0,62 & $0,29^{\text {ns }}$ & $0,36^{\text {ns }}$ & 0,50 \\
\hline VA $\times$ PG & 0,82 & 0,88 & 0,72 & 0,75 & 0,78 & $0,35^{\text {ns }}$ & 0,55 & 0,42 & 0,59 \\
\hline $\mathrm{N}$ & 42 & 42 & 43 & 39 & 46 & 35 & 41 & 30 & 42 \\
\hline
\end{tabular}

${ }_{2}^{1}$ Para identificação dos caracteres, consultar o Apêndice 1 .

${ }^{2}$ Para identificação dos cruzamentos que deram origem à estas populações, consultar o Apêndice 6 .

${ }^{n s}$ Não Significativo. As correlações não assinaladas são todas significativas $(P \leq 0,05)$.

* EMGOPA-301 
Tabela 31 Estimativas de correlações fenotípicas de Pearson $\left(r_{\mathrm{p}}\right)$, valores mínimos (MIN.) e máximos (MAX.), entre seis caracteres combinados dois a dois, para um número médio de 39 plantas, dentro de cada população $\mathbf{F}_{2[4]}$ ou $\mathbf{F}_{3: 2[4]}$ de 45 cruzamentos quádruplos. Soja. Piracicaba - SP (Semeadura 04/12/92 ) e Maracaí - SP (Semeadura 02/12/93).

\begin{tabular}{|c|c|c|c|}
\hline CARACTERES & $r_{p}$ & MIN. $^{2}$ & MAX. $^{2-}$ \\
\hline & \multicolumn{3}{|c|}{ Populaçōes $F_{2|4|}$} \\
\hline $\begin{array}{l}\text { NDF } \times A P F \\
\text { NDF } \times \text { NDM } \\
\text { NDF } \times A P M \\
\text { NDF } \times \text { VA } \\
\text { NDF } \times \text { PG } \\
A P F \times N D M \\
A P F \times A P M \\
A P F \times V A \\
A P F \times P G \\
\text { NDM } \times A P M \\
N D M \times V A \\
N D M \times P G \\
A P M \times V A \\
A P M \times P G \\
V A \times P G\end{array}$ & 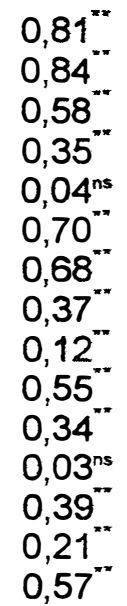 & $\begin{array}{c}0,31^{*} \\
0,29^{\text {ns }} \\
-0,02^{\text {ns }} \\
-0,17^{\text {ns }} \\
-0,48^{*} \\
0,12^{\text {ns }} \\
0,37^{*} \\
-0,18^{\text {ns }} \\
-0,46^{*} \\
0,09^{\text {ns }} \\
-0,19^{\text {ns }} \\
-0,53^{\text {"* }} \\
-0,02^{\text {ns }} \\
-0,37^{*} \\
0,22^{\text {ns }}\end{array}$ & 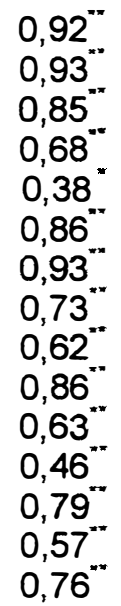 \\
\hline
\end{tabular}

Populações $F_{3: 2[4]}$

\begin{tabular}{|c|c|c|c|}
\hline $\begin{array}{l}\text { NDF } \times A P F \\
\text { NDF } \times N D M \\
N D F \times A P M \\
N D F \times V A \\
N D F \times P G \\
A P F \times N D M \\
A P F \times A P M \\
A P F \times V A \\
A P F \times P G \\
N D M \times A P M \\
N D M \times V A \\
N D M \times P G \\
A P M \times V A \\
A P M \times P G \\
V A \times P G\end{array}$ & 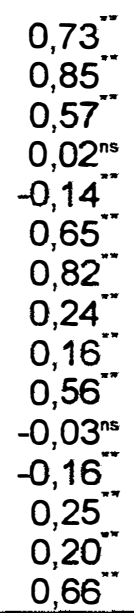 & $\begin{array}{r}0,20^{\text {ns }} \\
0,39^{*} \\
-0,09^{\text {ns }} \\
-0,34^{*} \\
-0,50^{\text {"* }} \\
0,14^{\text {ns }} \\
0,45^{\text {n* }} \\
-0,13^{\text {ns }} \\
-0,25^{\text {ns }} \\
0,09^{\text {ns }} \\
-0,48^{\text {"* }} \\
-0,51^{\text {nt }} \\
-0,23^{\text {ns }} \\
-0,26^{\text {ns }} \\
0,28^{\text {ns }}\end{array}$ & 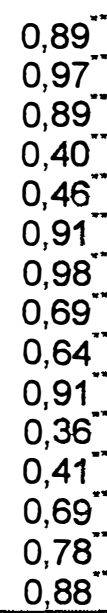 \\
\hline
\end{tabular}

* e* Significativos a $5 \%$ e $1 \%$ de probabilidade.

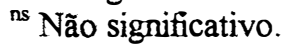

${ }^{1}$ Para identificação dos caracteres, consultar o Apêndice 1 .

${ }^{2}$ Dados tomados da tabela 30 . 
Tabela 32 Estimativas de correlações fenotípicas de Spearman entre as geraçōes $\mathbf{F}_{2[4]}$ e $\mathbf{F}_{3: 2[4]}$, para seis caracteres ${ }^{1}$ de 45 populações de cruzamentos quádruplos e 4 testemunhas. Soja. Piracicaba - SP (Semeadura 04/12/92) e Maracaí - SP ( Semeadura 02/12/93).

\begin{tabular}{|c|c|c|c|c|c|c|c|}
\hline POPULAÇŌES ${ }^{2}$ & $\overline{\mathrm{N}}$ & $\mathrm{NDF}$ & APF & NDM & APM & $\mathrm{VA}$ & PG \\
\hline 1 & 38 & $0,69^{*-}$ & $0,59^{*}$ & $0,71^{*}$ & $0,64^{*-}$ & $0,01^{\text {ns }}$ & $-0,17^{\text {ns }}$ \\
\hline 2 & 35 & $0,59^{*}$ & $0,52^{*}$ & $0,34^{\circ}$ & $0,46^{*}$ & $-0,08^{n s}$ & $-0,05^{n s}$ \\
\hline 3 & 32 & $0,79^{*}$ & $0,62^{*}$ & $0,60^{--}$ & $0,41^{*}$ & $-0,12^{\text {ns }}$ & $-0,21^{\text {ns }}$ \\
\hline 4 & 34 & $0,74^{*}$ & $0,50^{\cdots}$ & $0,63^{*}$ & $0,59^{*}$ & $0,11^{\text {ns }}$ & $0,20^{\mathrm{ns}}$ \\
\hline 5 & 40 & $0,83^{*}$ & $0,69^{*}$ & $0,85^{*}$ & $0,79 *$ & $-0,18^{\mathrm{ns}}$ & $0,17^{\mathrm{ns}}$ \\
\hline 6 & 35 & $0,49^{\circ}$ & $0,19^{\text {ns }}$ & $0,33^{\text {ns }}$ & $0,15^{\mathrm{n}}$ & $-0,21^{\mathrm{nx}}$ & $-0,13^{n s}$ \\
\hline 7 & 32 & $0,35^{*}$ & $0,18^{\text {ne }}$ & $0,45^{-}$ & $0,33^{n s}$ & $0,00^{\mathrm{ns}}$ & $-0,17^{\text {as }}$ \\
\hline 8 & 32 & $0,63^{\cdots}$ & $0,25^{\text {ns }}$ & $0,28^{\text {ns }}$ & $0,62^{*}$ & $-0,21^{\mathrm{ns}}$ & $0,08^{\mathrm{ns}}$ \\
\hline 9 & 34 & $0,84^{-}$ & $0,31^{\text {ns }}$ & $0,87^{-}$ & $0,22^{\text {ns }}$ & $0,24^{\mathrm{ms}}$ & $-0,15^{\mathrm{ns}}$ \\
\hline 10 & 35 & $0,64^{*}$ & $0,30^{\text {ns }}$ & $0,72^{*}$ & $0,46^{*}$ & $0,37^{*}$ & $-0,14^{\mathrm{ns}}$ \\
\hline 11 & 40 & $0,66^{*}$ & $0,33^{\circ}$ & $0,59^{\cdots}$ & $0,69^{*}$ & $0,02^{\text {ns }}$ & $-0,16^{\mathrm{ss}}$ \\
\hline 12 & 41 & $0,74^{*}$ & $0,61^{*}$ & $0,64^{*}$ & $0,66^{*}$ & $0,17^{n s}$ & $0,22^{n s}$ \\
\hline 13 & 41 & $0,81^{*}$ & $0,34^{\circ}$ & $0,56^{*}$ & $0,51^{*}$ & $0,36 \cdots$ & $0,10^{\text {ns }}$ \\
\hline 14 & 38 & $0,68^{*}$ & $0,47^{\cdots}$ & $0,67^{-}$ & $0,53^{*}$ & $0,18^{\mathrm{n}}$ & $0,08^{\text {ns }}$ \\
\hline 15 & 34 & $0,29^{n s}$ & $0,20^{\text {ns }}$ & $0,41^{\circ}$ & $0,36^{\circ}$ & $-0,06^{\mathrm{ns}}$ & $0,10^{\text {ns }}$ \\
\hline 16 & 40 & $0,77^{-}$ & $0,45^{*}$ & $0,56^{\cdots}$ & $0,57^{-}$ & $0,03^{\mathrm{ma}}$ & $0,08^{\mathrm{s}}$ \\
\hline 17 & 33 & $0,70^{-}$ & $0,70^{-}$ & $0,71^{-}$ & $0,74^{-}$ & $0,05^{\text {ms }}$ & $0,06^{\text {ns }}$ \\
\hline 18 & 39 & $0,67^{-}$ & $0,52^{*}$ & $0,57^{-}$ & $0,47^{*}$ & $0,04^{\text {na }}$ & $-0,04^{\mathrm{n}}$ \\
\hline 19 & 44 & $0,53^{*}$ & $0,57^{-}$ & $0,65^{*}$ & $0,47^{-}$ & $-0,30^{\circ}$ & $-0,23^{\text {ns }}$ \\
\hline 20 & 36 & $0,70^{*}$ & $0,54^{--}$ & $0,68^{-*}$ & $0,57^{*}$ & $0,14^{\text {n }}$ & $0,26^{\mathrm{ns}}$ \\
\hline 21 & 38 & $0,84^{*}$ & $0,60^{*}$ & $0,70^{*}$ & $0,74^{*}$ & $0,26^{n s}$ & $0,37^{\circ}$ \\
\hline 22 & 36 & $0,79^{*}$ & $0,42^{*}$ & $0,72^{*}$ & $0,62^{*}$ & $0,35^{*}$ & $0,54^{*-}$ \\
\hline 23 & 36 & $0,71^{*}$ & $0,59^{*}$ & $0,45^{*}$ & $0,28^{\text {ns }}$ & $0,14^{\text {ns }}$ & $0,31^{\text {ns }}$ \\
\hline 24 & 35 & $0,69 *$ & $0,35^{\circ}$ & $0,56^{*}$ & $0,51^{*}$ & $-0,06^{\mathrm{ns}}$ & $0,08^{\text {ns }}$ \\
\hline 25 & 35 & $0,78^{*}$ & $0,57^{\cdots}$ & $0,83^{*}$ & $0,76^{\circ}$ & $-0,08^{n s}$ & $-0,07^{\text {n }}$ \\
\hline 26 & 34 & $0,59^{\circ}$ & $0,38^{\circ}$ & $0,66^{-}$ & $0,30^{\mathrm{m}}$ & $0,18^{\mathrm{m}}$ & $0,06^{\mathrm{ns}}$ \\
\hline 27 & 40 & $0,60^{*}$ & $0,48^{*}$ & $0,50^{-}$ & $0,36^{\circ}$ & $0,31^{\bullet}$ & $0,05^{\text {ns }}$ \\
\hline 28 & 41 & $0,76^{\circ}$ & $0,61^{*}$ & $0,64^{*}$ & $0,67^{-}$ & $-0,09^{\mathrm{m}}$ & $0,05^{\mathrm{ns}}$ \\
\hline 29 & 33 & $0,58^{-}$ & $0,53^{-}$ & $0,58^{-}$ & $0,75^{-}$ & $0,22^{\mathrm{na}}$ & $-0,13^{\mathrm{ns}}$ \\
\hline 30 & 38 & $0,52^{\circ}$ & $0,14^{n s}$ & $0,53^{-\bullet}$ & $0,56^{* *}$ & $0,32^{\circ}$ & $0,02^{n s}$ \\
\hline 31 & 27 & $0,46^{\circ}$ & $0,50 *$ & $0,38^{\circ}$ & $0,60^{\circ}$ & $0,15^{n s}$ & $-0,03^{\mathrm{ns}}$ \\
\hline 32 & 41 & $0,51^{*}$ & $0,17^{\text {ns }}$ & $0,67^{\cdots}$ & $0,52^{*}$ & $0,04^{n s}$ & $0,06^{\text {ns }}$ \\
\hline 33 & 38 & $0,71^{\cdots}$ & $0,62 *$ & $0,74^{--}$ & $0,58^{\circ}$ & $0,22^{\text {ns }}$ & $0,11^{\mathrm{ns}}$ \\
\hline 34 & 38 & $0,32^{\circ}$ & $0,29^{\mathrm{ns}}$ & $0,59^{*}$ & $0,44^{*}$ & $0,17^{\mathrm{n} x}$ & $0,11^{\text {ns }}$ \\
\hline 35 & 40 & $0,69^{\circ}$ & $0,14^{\text {ns }}$ & $0,55^{\circ}$ & $0,39 *$ & $-0,23^{\mathrm{n}}$ & $-0,14^{n s}$ \\
\hline 36 & 35 & $0,78^{-}$ & $0,76^{*}$ & $0,67^{\circ}$ & $0,87^{*}$ & $0,16^{\text {so }}$ & $0,07^{\mathrm{ns}}$ \\
\hline 37 & 34 & $0,79^{--}$ & $0,51^{\cdots}$ & $0,81^{--}$ & $0,57^{*}$ & $-0,29^{\mathrm{ns}}$ & $0,14^{\mathrm{s} s}$ \\
\hline 38 & 42 & $0,70^{-}$ & $0,59^{*}$ & $0,71^{-}$ & $0,54^{*}$ & $0,35^{\circ}$ & $0,32^{\circ}$ \\
\hline 39 & 33 & $0,55^{-}$ & $0,35^{\circ}$ & $0,62^{-}$ & $0,62^{-*}$ & $-0,02^{\mathrm{ns}}$ & $-0,07^{-12}$ \\
\hline 40 & 41 & $0,72^{-}$ & $0,57^{\circ}$ & $0,57^{-}$ & $0,75^{*}$ & $0,15^{n s}$ & $0,28^{n s}$ \\
\hline 41 & 39 & $0,77^{\cdots}$ & $0,43^{*}$ & $0,76^{*}$ & $0,59^{*}$ & $0,11^{n s}$ & $0,19^{\text {ns }}$ \\
\hline 42 & 41 & $0,67^{\circ}$ & $0,40^{*}$ & $0,77^{-}$ & $0,64 *$ & $0,42^{*}$ & $0,07^{n s}$ \\
\hline 43 & 42 & $0,81^{*}$ & $0,17^{\mathrm{ns}}$ & $0,67^{\cdots}$ & $0,61^{*}$ & $0,04^{n s}$ & $0,21^{n s}$ \\
\hline 44 & 38 & $0,76^{\circ}$ & $0,56^{*}$ & $0,63^{*}$ & $0,33^{\circ}$ & $0,25^{\mathrm{ns}}$ & $0,23^{\text {ns }}$ \\
\hline 45 & 42 & $0,50^{\cdots}$ & $0,41^{*}$ & $0,67^{*}$ & $0,76^{*}$ & $-0,01^{\text {ns }}$ & $0,05^{n s}$ \\
\hline TOTAL POP. & 1670 & $0,77^{-}$ & $0,52^{\prime-}$ & $0,70^{--}$ & $0,63^{--}$ & $0,13^{-}$ & $0,10^{\prime-}$ \\
\hline Cristalina & 35 & $0,19^{n s}$ & $-0,09^{n s}$ & $-0,01^{n s}$ & $0,14^{\text {ns }}$ & $-0,15^{\text {ns }}$ & $0,23^{\text {ns }}$ \\
\hline IAC-8 & 41 & $0,11^{n s}$ & $0,34^{\circ}$ & $0,27^{n s}$ & $0,07^{\mathrm{ns}}$ & $0,39^{*}$ & $0,59^{\circ}$ \\
\hline EMGOPA-301 & 28 & $0,46^{\circ}$ & $-0,01^{n s}$ & $0,27^{\text {ns }}$ & $0,16^{\mathrm{ns}}$ & $0,14^{\text {ns }}$ & $0,55^{\mathrm{ns}}$ \\
\hline SS-1 & 40 & $0,06^{\mathrm{na}}$ & $0,10^{\text {ns }}$ & $0,18^{n s}$ & $0,15^{\mathrm{ns}}$ & $-0,02^{\mathrm{ns}}$ & $0,14^{\mathrm{ns}}$ \\
\hline TOTAL TEST. & 144 & $0,76^{-}$ & $0,43^{*}$ & $0,80^{-}$ & $0,36^{*}$ & $0,14^{\text {ns }}$ & $0,41^{-\infty}$ \\
\hline
\end{tabular}

${ }^{n s}$ Não significativo. " e " significativos ao nivel de 1 e $5 \%$ pelo teste " $t$ ", respectivamente.

${ }^{1}$ Para identificar os caracteres, consultar o Apêndice 1.

${ }^{2}$ Para identificar as populacōes, consultar o Apêndice 6. 
Tabela 33 Herdabilidades no sentido "restrito" de seis caracteres ${ }^{2}$, em 45 populações de cruzamentos quádruplos, com base em plantas $F_{2[4]}$, descendente $\mathbf{F}_{3: 2[4]}$. Soja Piracicaba-SP ( Semeadura 04/12/92) e Maracai - SP (Semeadura 02/12/93).

\begin{tabular}{|c|c|c|c|c|c|c|}
\hline \multirow[b]{2}{*}{ POPULAÇȦO ${ }^{3}$} & \multicolumn{5}{|c|}{ CARACTERES $^{2}$} & \multirow[b]{2}{*}{$\mathrm{PG}^{*}$} \\
\hline & NDF & $\overline{\mathrm{APF}}$ & NDM & $\overline{\mathrm{APM}}$ & $\mathrm{VA}^{*}$ & \\
\hline 1 & 0,51 & 0,34 & 0,57 & 0,41 & $-0,02$ & $-0,13$ \\
\hline 2 & 0,22 & 0,24 & 0,08 & 0,28 & $-0,07$ & 0,08 \\
\hline 3 & 0,48 & 0,42 & 0,48 & 0,31 & $-0,07$ & $-0,17$ \\
\hline 4 & 0,44 & 0,30 & 0,41 & 0,39 & 0,07 & 0,18 \\
\hline 5 & 0,55 & 0,44 & 0,58 & 0,53 & $-0,11$ & 0,16 \\
\hline 6 & 0,37 & 0,16 & 0,14 & 0,18 & $-0,14$ & $-0,10$ \\
\hline 7 & 0,15 & 0,12 & 0,28 & 0,20 & 0,01 & $-0,08$ \\
\hline 8 & 0,50 & 0,27 & 0,43 & 0,50 & $-0,12$ & 0,06 \\
\hline 9 & 0,58 & 0,22 & 0,54 & 0,17 & 0,17 & $-0,03$ \\
\hline 10 & 0,47 & 0,25 & 0,57 & 0,33 & 0,23 & $-0,09$ \\
\hline 11 & 0,53 & 0,29 & 0,49 & 0,46 & $-0,01$ & $-0,13$ \\
\hline 12 & 0,47 & 0,41 & 0,39 & 0,37 & 0,13 & 0,13 \\
\hline 13 & 0,58 & 0,26 & 0,38 & 0,39 & 0,25 & 0,03 \\
\hline 14 & 0,48 & 0,36 & 0,40 & 0,45 & 0,13 & 0,13 \\
\hline 15 & 0,12 & 0,12 & 0,04 & 0,29 & 0,01 & $-0,01$ \\
\hline 16 & 0,58 & 0,42 & 0,50 & 0,48 & 0,03 & $-0,05$ \\
\hline 17 & 0,49 & 0,47 & 0,44 & 0,51 & 0,05 & 0,05 \\
\hline 18 & 0,44 & 0,38 & 0,36 & 0,27 & 0,02 & $-0,02$ \\
\hline 19 & 0,37 & 0,37 & 0,32 & 0,30 & $-0,20$ & $-0,12$ \\
\hline 20 & 0,50 & 0,37 & 0,44 & 0,39 & 0,09 & 0,19 \\
\hline 21 & 0,52 & 0,43 & 0,39 & 0,48 & 0,23 & 0,26 \\
\hline 22 & 0,54 & 0,25 & 0,47 & 0,37 & 0,22 & 0,23 \\
\hline 23 & 0,45 & 0,36 & 0,29 & 0,05 & 0,09 & 0,18 \\
\hline 24 & 0,50 & 0,25 & 0,38 & 0,29 & $-0,04$ & 0,17 \\
\hline 25 & 0,54 & 0,44 & 0,45 & 0,51 & $-0,05$ & $-0,05$ \\
\hline 26 & 0,41 & 0,28 & 0,36 & 0,23 & 0,09 & $-0,01$ \\
\hline 27 & 0,33 & 0,36 & 0,26 & 0,30 & 0,20 & 0,01 \\
\hline 28 & 0,49 & 0,41 & 0,39 & 0,47 & $-0,04$ & 0,07 \\
\hline 29 & 0,54 & 0,38 & 0,46 & 0,51 & 0,14 & $-0,04$ \\
\hline 30 & 0,44 & 0,07 & 0,32 & 0,36 & 0,17 & 0,11 \\
\hline 31 & 0,41 & 0,35 & 0,21 & 0,40 & 0,13 & 0,06 \\
\hline 32 & 0,42 & 0,20 & 0,42 & 0,33 & 0,02 & 0,06 \\
\hline 33 & 0,48 & 0,41 & 0,49 & 0,38 & 0,16 & 0,09 \\
\hline 34 & 0,32 & 0,22 & 0,49 & 0,28 & 0,11 & 0,04 \\
\hline 35 & 0,52 & 0,18 & 0,39 & 0,29 & $-0,13$ & $-0,10$ \\
\hline 36 & 0,58 & 0,52 & 0,50 & 0,56 & 0,10 & 0,08 \\
\hline 37 & 0,53 & 0,40 & 0,53 & 0,37 & $-0,15$ & 0,05 \\
\hline 38 & 0,51 & 0,34 & 0,47 & 0,32 & 0,23 & 0,13 \\
\hline 39 & 0,45 & 0,30 & 0,36 & 0,52 & 0,00 & $-0,04$ \\
\hline 40 & 0,40 & 0,33 & 0,40 & 0,49 & 0,10 & 0,16 \\
\hline 41 & 0,58 & 0,39 & 0,50 & 0,43 & 0,10 & 0,04 \\
\hline 42 & 0,43 & 0,34 & 0,52 & 0,47 & 0,28 & 0,02 \\
\hline 43 & 0,54 & 0,11 & 0,46 & 0,38 & 0,02 & 0,13 \\
\hline 44 & 0,49 & 0,33 & 0,45 & 0,15 & 0,11 & 0,15 \\
\hline 45 & 0,31 & 0,33 & 0,39 & 0,49 & 0,01 & $-0,01$ \\
\hline MEDDIA & 0,46 & 0,32 & 0,40 & 0,37 & 0,08 & 0,07 \\
\hline
\end{tabular}


Tabela 34 PG: Ganho genético em g/planta $(\Delta \mathrm{gr})$ e percentual $(\Delta \mathrm{gr} \%)$ obtidos em $\mathbf{F}_{3: 2[4] \text {. }}$ pela seleção de plantas $F_{2[4]}$ em Piracicaba '. Número de plantas $(\mathrm{Np})$ e médias da geração $F_{3: 2[4]}(\mu \mathrm{p})$, número de plantas $F_{2[4]}: F_{3: 2[4]}$ selecionadas $(\mathrm{Ns})$, média da população $\mathrm{F}_{3: 2[4]}$ selecionada $\left(\bar{\mu} \mathrm{s}^{1}\right)$ e percentual de plantas selecionadas (\%s). Soja, cruzamentos quádruplos. Maracaí-SP (sem. 02/12/93).

\begin{tabular}{|c|c|c|c|c|c|c|c|}
\hline POPULAÇ $\tilde{A} O^{3}$ & $\mathrm{~Np}$ & $\mu \mathrm{p}(\mathrm{g} / \mathrm{pl})$ & Ns & $\overline{\mu s}{ }^{1}(\mathrm{~g} / \mathrm{pl})$ & $\% s$ & $\Delta \mathrm{gr}$ & $\Delta \mathrm{gr} \%$ \\
\hline 1 & 41 & 48,30 & 11 & 41,02 & 27 & $-7,28$ & $-15,07$ \\
\hline 2 & 35 & 49,19 & 9 & 47,25 & 26 & $-1,94$ & $-3,94$ \\
\hline 3 & 33 & 73,61 & 14 & 62,47 & 42 & $-11,14$ & $-15,13$ \\
\hline 4 & 38 & 53,97 & 10 & 54,67 & 26 & 0,70 & 1,30 \\
\hline 5 & 41 & 48,66 & 7 & 54,46 & 17 & 5,80 & 11,92 \\
\hline 6 & 36 & 72,36 & 14 & 70,70 & 39 & $-1,66$ & $-2,29$ \\
\hline 7 & 34 & 58,62 & 6 & 59,18 & 18 & 0,56 & 0,96 \\
\hline 8 & 37 & 63,56 & 7 & 62,11 & 19 & $-1,45$ & $-2,28$ \\
\hline 9 & 35 & 63,82 & 11 & 61,53 & 31 & $-2,30$ & $-3,60$ \\
\hline 10 & 37 & 56,86 & 8 & 53,93 & 22 & $-2,94$ & $-5,17$ \\
\hline 11 & 40 & 58,60 & 6 & 49,34 & 15 & $-9,27$ & $-15,82$ \\
\hline 12 & 42 & 54,01 & 17 & 64,27 & 40 & 10,26 & 19,00 \\
\hline 13 & 42 & 52,45 & 9 & 57,04 & 21 & 4,59 & 8,75 \\
\hline 14 & 42 & 55,76 & 9 & 57,25 & 21 & 1,49 & 2,67 \\
\hline 15 & 35 & 61,19 & 6 & 65,26 & 17 & 4,07 & 6,65 \\
\hline 16 & 41 & 57,53 & 17 & 59,94 & 41 & 2,41 & 4,19 \\
\hline 17 & 36 & 40,56 & 5 & 45,55 & 14 & 4,99 & 12,30 \\
\hline 18 & 41 & 56,17 & 7 & 61,61 & 17 & 5,44 & 9,68 \\
\hline 19 & 46 & 66,49 & 17 & 57,70 & 37 & $-8,79$ & $-13,22$ \\
\hline 20 & 38 & 64,33 & 11 & 73,86 & 29 & 9,53 & 14,81 \\
\hline 21 & 39 & 73,89 & 22 & 79,72 & 56 & 5,83 & 7,89 \\
\hline 22 & 40 & 66,95 & 19 & 87,06 & 48 & 20,11 & 30,04 \\
\hline 23 & 36 & 73,77 & 21 & 79,25 & 58 & 5,48 & 7,43 \\
\hline 24 & 37 & 63,87 & 8 & 72,93 & 22 & 9,06 & 14,19 \\
\hline 25 & 36 & 45,65 & 4 & 36,25 & 11 & $-9,40$ & $-20,59$ \\
\hline 26 & 35 & 48,56 & 12 & 49,24 & 34 & 0,68 & 1,40 \\
\hline 27 & 41 & 59,67 & 10 & 66,07 & 24 & 6,40 & 10,73 \\
\hline 28 & 41 & 59,36 & 10 & 61,17 & 24 & 1,81 & 3,05 \\
\hline 29 & 38 & 68,79 & 11 & 65,00 & 29 & $-3,79$ & $-5,51$ \\
\hline 30 & 39 & 56,92 & 5 & 68,99 & 13 & 12,07 & 21,21 \\
\hline 31 & 31 & 50,39 & 3 & 71,80 & 10 & 21,41 & 42,49 \\
\hline 32 & 42 & 56,98 & 4 & 72,47 & 10 & 15,49 & 27,18 \\
\hline 33 & 41 & 57,74 & 12 & 64,43 & 29 & 6,69 & 11,59 \\
\hline 34 & 43 & 70,57 & 13 & 75,58 & 30 & 5,01 & 7,10 \\
\hline 35 & 42 & 60,97 & 11 & 57,90 & 26 & $-3,07$ & $-5,04$ \\
\hline 36 & 37 & 60,08 & 11 & 62,67 & 30 & 2,59 & 4,31 \\
\hline 37 & 36 & 54,62 & 8 & 70,49 & 22 & 15,87 & 29,06 \\
\hline 38 & 43 & 45,41 & 8 & 47,56 & 19 & 2,15 & 4,73 \\
\hline 39 & 33 & 62,21 & 5 & 59,68 & 15 & $-2,53$ & $-4,07$ \\
\hline 40 & 44 & 55,28 & 12 & 60,73 & 27 & 5,45 & 9,86 \\
\hline 41 & 43 & 70,29 & 3 & 83,90 & 7 & 13,61 & 19,36 \\
\hline 42 & 42 & 55,50 & 5 & 51,08 & 12 & $-4,42$ & $-7,96$ \\
\hline 43 & 43 & 53,04 & 12 & 55,41 & 28 & 2,37 & 4,47 \\
\hline 44 & 39 & 59,86 & 3 & 68,17 & 8 & 8,31 & 13,88 \\
\hline 45 & 45 & 57,99 & 5 & 48,10 & 11 & $-9,89$ & $-17,05$ \\
\hline Média $^{2}$ & 39 & 58,74 & 10 & 63,35 & 25 & 4,61 & 7,85 \\
\hline
\end{tabular}

Seleção realizada em $\mathrm{F}_{2[4]}$ em Piracicaba, de plantas com PG > $141 \mathrm{~g} /$ planta.

${ }^{2}$ Médias de produtividade ponderadas pelo número de plantas da população (Np e Ns).

${ }^{3}$ Para identificação dos cruzamentos que originaram estas populações, consultar Apêndice 6. 
Tabela 35 PG: Alterações ${ }^{1}$ ocorridas nas médias de cinco caracteres ${ }^{2}$ das populaçôes $\mathbf{F}_{3: 2[4]}$, proporcionadas pela seleção em $F_{2[4]}$, para o caráter produtividade de grãos ${ }^{4}$ (PG). Soja, cruzamentos quádruplos. Maracaí, SP (semeadura 02/12/93).

\begin{tabular}{|c|c|c|c|c|c|}
\hline POPULAÇŌES & NDF & $\overline{\mathrm{APF}}$ & $\overline{\mathrm{NDM}}$ & $\overline{\mathrm{APM}}$ & VA \\
\hline 1 & 8 & 7,23 & 17 & 10,01 & 0,24 \\
\hline 2 & 3 & 5,00 & 5 & 4,51 & 0,01 \\
\hline 3 & 2 & 1,38 & 2 & 0,81 & $-0,29$ \\
\hline 4 & 1 & 4,25 & 4 & 6,89 & 0,31 \\
\hline 5 & 0 & 6,49 & -3 & 8,32 & 0,08 \\
\hline 6 & 0 & $-0,10$ & -2 & $-1,22$ & $-0,06$ \\
\hline 7 & 2 & 1,70 & 4 & 4,15 & 0,18 \\
\hline 8 & 8 & 18,46 & 15 & 22,97 & $-0,18$ \\
\hline 9 & 9 & 7,14 & 14 & $-5,92$ & $-0,18$ \\
\hline 10 & 5 & 7,30 & 13 & 10,17 & 0,34 \\
\hline 11 & 0 & 1,20 & 4 & $-3,45$ & 0,10 \\
\hline 12 & 0 & 2,08 & -1 & $-1,98$ & 0,38 \\
\hline 13 & 1 & 1,15 & 3 & 3,28 & 0,29 \\
\hline 14 & 2 & 7,63 & 2 & 10,26 & 0,54 \\
\hline 15 & -1 & 1,60 & -6 & 3,36 & $-0,23$ \\
\hline 16 & -1 & $-0,11$ & -3 & 0,15 & 0,01 \\
\hline 17 & 7 & 18,58 & 9 & 18,30 & $-0,10$ \\
\hline 18 & 1 & $-0,01$ & -4 & $-7,06$ & $-0,21$ \\
\hline 19 & 1 & 1,04 & 3 & 0,28 & $-0,39$ \\
\hline 20 & 3 & 6,32 & 8 & 7,36 & 0,18 \\
\hline 21 & 5 & 6,52 & 5 & 8,23 & 0,12 \\
\hline 22 & 0 & 4,52 & 2 & 7,46 & 0,53 \\
\hline 23 & 1 & 1,16 & 0 & $-1,09$ & 0,09 \\
\hline 24 & 3 & 8,70 & 8 & 12,65 & $-0,04$ \\
\hline 25 & 5 & 3,25 & 6 & 13,89 & $-0,31$ \\
\hline 26 & 0 & $-1,67$ & 1 & $-3,77$ & $-0,11$ \\
\hline 27 & 1 & 1,00 & -3 & 3,80 & 0,49 \\
\hline 28 & 2 & 5,12 & 5 & 8,01 & $-0,28$ \\
\hline 29 & -1 & $-1,65$ & -2 & 1,27 & $-0,04$ \\
\hline 30 & 6 & 13,01 & 6 & 17,99 & 0,25 \\
\hline 31 & -1 & $-1,42$ & 6 & $-2,06$ & 0,05 \\
\hline 32 & 2 & 5,39 & 0 & 7,49 & 0,38 \\
\hline 33 & 2 & 0,24 & 1 & $-0,26$ & 0,46 \\
\hline 34 & 0 & $-1,69$ & 3 & $-3,83$ & 0,13 \\
\hline 35 & 4 & 3,52 & 8 & 1,71 & 0,05 \\
\hline 36 & -3 & $-3,63$ & -9 & $-2,61$ & 0,19 \\
\hline 37 & -5 & $-3,66$ & -8 & $-7,31$ & 0,44 \\
\hline 38 & 4 & 5,87 & 7 & 6,33 & 0,28 \\
\hline 39 & I & 4,09 & 8 & 11,01 & 0,04 \\
\hline 40 & 1 & 4,01 & 4 & 4,19 & 0,36 \\
\hline 41 & 1 & $-2,67$ & -7 & 8,86 & 0,24 \\
\hline 42 & 3 & 2,08 & 1 & 1,52 & $-0,04$ \\
\hline 43 & 4 & 4,91 & 6 & 6,96 & 0,43 \\
\hline 44 & -1 & $-4,84$ & -9 & $-6,39$ & $-0,08$ \\
\hline 45 & -1 & $-8,42$ & -1 & $-4,33$ & $-0,82$ \\
\hline MEDIA $^{12}$ & 2 & 3,03 & 3 & 3,34 & 0,12 \\
\hline
\end{tabular}

${ }^{1}$ Alteração média do caráter na população $F_{3: 2[4]}$ selecionada $=\bar{\mu}_{c} F_{3: 2[4]}$ selec. $-\bar{\mu}_{\mathrm{c}} \mathrm{F}_{3: 2[4]}$ original, com $\mathrm{c}=\mathrm{NDF}, \mathrm{APF}, \mathrm{NDM}, \mathrm{APM}, \mathrm{VA} .{ }^{\text {la }}$ Médias ponderadas pelo núm. de plantas selecionadas.

${ }^{2}$ Para identificação dos caracteres, consultar Apêndice 1. ${ }^{3}$ Os cruzamentos constam no Apêndice 6.

${ }^{4}$ Seleção em $F_{2}$ de plantas com PG $>141 \mathrm{~g} /$ planta. (Cristalina = testemunha mais produtiva). 
Tabela 36 VA: Ganho genetico em g/planta $(\Delta \mathrm{gr})$ e percentual $(\Delta \mathrm{Gr} \%)$, obtidos em $\mathbf{F}_{3: 2[4]}$, pela seleção de plantas $F_{2[4]}$, com base no Valor Agronômico. Número de plantas $(\mathrm{Np})$ e médias ( $\left.\bar{\mu} \mathrm{p}\right)$ da

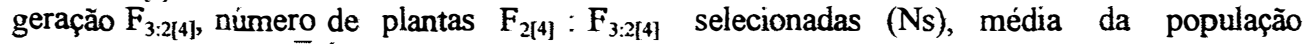
$\mathrm{F}_{3: 2[4]}$ selecionada $\left(\mu \mathrm{s}^{1}\right)$ e percentual da população selecionado $(\% \mathrm{~s})$. Soja, cruzamentos quádruplos. Maracaí - SP (semeadura 02/12/93).

\begin{tabular}{|c|c|c|c|c|c|c|c|}
\hline POPULAÇÓES & $\overline{N p}$ & $\mu \mathrm{p}(\mathrm{g} / \mathrm{pl})$ & $\overline{\mathrm{Ns}}$ & $\bar{\mu} \mathrm{s}^{1}(\mathrm{~g} / \mathrm{pl})$. & $\%$ & $\Delta \mathrm{Gr}$ & $\Delta \mathrm{Gr} \%$ \\
\hline I & 41 & 48,30 & 19 & 39,65 & 46 & $-8,65$ & $-17,91$ \\
\hline 2 & 35 & 49,19 & 30 & 48,73 & 86 & $-0,46$ & $-0,94$ \\
\hline 3 & 33 & 73,61 & 20 & 69,80 & 61 & $-3,81$ & $-5,18$ \\
\hline 4 & 38 & 53,97 & 19 & 53,79 & 50 & $-0,18$ & $-0,33$ \\
\hline 5 & 41 & 48,66 & 32 & 48,58 & 78 & $-0,08$ & $-0,16$ \\
\hline 6 & 36 & 72,36 & 30 & 71,00 & 83 & $-1,36$ & $-1,88$ \\
\hline 7 & 34 & 58,62 & 18 & 61,62 & 53 & 3,00 & 5,12 \\
\hline 8 & 37 & 63,56 & 22 & 59,57 & 59 & $-3,99$ & $-6,28$ \\
\hline 9 & 35 & 63,82 & 15 & 57,50 & 43 & $-6,32$ & $-9,91$ \\
\hline 10 & 37 & 56,86 & 23 & 56,15 & 62 & $-0,71$ & $-1,25$ \\
\hline 11 & 40 & 58,60 & 19 & 58,88 & 48 & 0,28 & 0,48 \\
\hline 12 & 42 & 54,01 & 32 & 55,91 & 76 & 1,90 & 3,52 \\
\hline 13 & 42 & 52,45 & 28 & 52,70 & 67 & 0,25 & 0,47 \\
\hline 14 & 42 & 55,76 & 29 & 57,12 & 69 & 1,36 & 2,44 \\
\hline 15 & 35 & 61,19 & 18 & 57,62 & 51 & $-3,57$ & $-5,83$ \\
\hline 16 & 41 & 57,53 & 38 & 58,85 & 93 & 1,32 & 2,29 \\
\hline 17 & 36 & 40,56 & 21 & 45,75 & 58 & 5,19 & 12,80 \\
\hline 18 & 41 & 56,17 & 23 & 56,21 & 56 & 0,04 & 0,07 \\
\hline 19 & 46 & 66,49 & 41 & 66,90 & 89 & 0,41 & 0,61 \\
\hline 20 & 38 & 64,33 & 26 & 66,56 & 68 & 2,23 & 3,47 \\
\hline 21 & 39 & 73,89 & 30 & 80,17 & 77 & 6,28 & 8,50 \\
\hline 22 & 40 & 66,95 & 26 & 76,08 & 65 & 9,13 & 13,64 \\
\hline 23 & 36 & 73,77 & 28 & 77,58 & 78 & 3,81 & 5,16 \\
\hline 24 & 37 & 63,87 & 19 & 61,11 & 51 & $-2,76$ & $-4,32$ \\
\hline 25 & 36 & 45,65 & 18 & 43,25 & 50 & $-2,40$ & $-5,26$ \\
\hline 26 & 35 & 48,56 & 29 & 49,09 & 83 & 0,53 & 1,10 \\
\hline 27 & 41 & 59,67 & 25 & 60,99 & 61 & 1,32 & 2,21 \\
\hline 28 & 41 & 59,36 & 24 & 60,26 & 59 & 0,90 & 1,52 \\
\hline 29 & 38 & 68,79 & 19 & 67,54 & 50 & $-1,25$ & $-1,81$ \\
\hline 30 & 39 & 56,92 & 16 & 65,67 & 41 & 8,75 & 15,37 \\
\hline 31 & 31 & 50,39 & 17 & 51,84 & 55 & 1,45 & 2,89 \\
\hline 32 & 42 & 56,98 & 16 & 56,39 & 38 & $-0,59$ & $-1,03$ \\
\hline 33 & 41 & 57,74 & 25 & 57,34 & 61 & $-0,40$ & $-0,70$ \\
\hline 34 & 43 & 70,57 & 20 & 78,09 & 47 & 7,52 & 10,65 \\
\hline 35 & 42 & 60,97 & 22 & 56,00 & 52 & $-4,97$ & $-8,15$ \\
\hline 36 & 37 & 60,08 & 28 & 62,74 & 76 & 2,66 & 4,43 \\
\hline 37 & 36 & 54,62 & 29 & 57,04 & 81 & 2,42 & 4,43 \\
\hline 38 & 43 & 45,41 & 15 & 52,73 & 35 & 7,32 & 16,13 \\
\hline 39 & 33 & 62,21 & 11 & 65,25 & 33 & 3,04 & 4,89 \\
\hline 40 & 44 & 55,28 & 34 & 57,75 & 77 & 2,47 & 4,46 \\
\hline 41 & 43 & 70,29 & 12 & 86,08 & 28 & 15,79 & 22,46 \\
\hline 42 & 42 & 55,50 & 17 & 56,20 & 40 & 0,70 & 1,27 \\
\hline 43 & 43 & 53,04 & 28 & 53,53 & 65 & 0,49 & 0,93 \\
\hline 44 & 39 & 59,86 & 24 & 59,39 & 62 & $-0,47$ & $-0,78$ \\
\hline 45 & 45 & 57,99 & 17 & 54,37 & 38 & $-3,62$ & $-6,24$ \\
\hline $\mathrm{MEDIA}^{3}$ & 39 & 58,74 & 23 & 59,78 & 59 & 1,02 & 1,73 \\
\hline
\end{tabular}

Seleção de plantas $\mathrm{F}_{2[4]}$ com VA $\geq 4$ (boas e excelentes).

${ }^{2}$ Para identificação dos cruzamentos, consultar o Apêndice 6.

${ }^{3}$ Médias de produtividade ponderadas pelo número de plantas da população (Np e Ns). 
Tabela 37 VA: Alterações ${ }^{1}$ ocorridas nas médias de cinco caracteres ${ }^{2}$ de populações $\mathbf{F}_{3: 2[4]}$ proporcionadas pela seleção em $F_{2[4]}$ de plantas com Valor Agronômico (VA) igual ou superior a 4 (boas e excelentes). Soja, cruzamentos quádruplos. Maracai - SP (semeadura $02 / 12 / 93$ ).

\begin{tabular}{|c|c|c|c|c|c|}
\hline POPULACOES $^{3}$ & NDF & APF & NDM & APM & VA \\
\hline 1 & 3 & 3,13 & 11 & 5,11 & $-0,03$ \\
\hline 2 & 0 & $-0,21$ & 0 & $-0,24$ & $-0,04$ \\
\hline 3 & 1 & 0,52 & 1 & $-1,31$ & $-0,14$ \\
\hline 4 & 0 & 0,71 & 1 & 1,57 & 0,06 \\
\hline 5 & 3 & 4,44 & 6 & 4,63 & $-0,03$ \\
\hline 6 & 1 & 1,41 & 2 & 1,09 & $-0,06$ \\
\hline 7 & 3 & 0,81 & 3 & 2,21 & 0,18 \\
\hline 8 & 1 & 4,71 & 2 & 5,43 & $-0,12$ \\
\hline 9 & 6 & 4,27 & 16 & $-3,50$ & 0,24 \\
\hline 10 & 2 & 1,66 & 4 & 3,43 & 0,16 \\
\hline 11 & 2 & 3,02 & 7 & 4,40 & 0,01 \\
\hline 12 & 1 & 2,49 & 1 & $-0,19$ & 0,13 \\
\hline 13 & 0 & 1,58 & -1 & 1,56 & 0,12 \\
\hline 14 & 3 & 4,73 & 3 & 6,65 & 0,15 \\
\hline 15 & 1 & 0,99 & 0 & 1,53 & $-0,06$ \\
\hline 16 & 0 & 0,15 & 0 & 0,45 & 0,04 \\
\hline 17 & 3 & 5,91 & 5 & 9,31 & 0,02 \\
\hline 18 & 1 & 2,11 & 0 & 2,58 & 0,05 \\
\hline 19 & 0 & 0,33 & 1 & 0,11 & 0,00 \\
\hline 20 & 2 & 2,88 & 4 & 4,35 & 0,08 \\
\hline 21 & 4 & 4,96 & 4 & 5,60 & 0,20 \\
\hline 22 & 1 & 2,27 & 3 & 3,99 & 0,23 \\
\hline 23 & I & 0,79 & 2 & 0,26 & 0,07 \\
\hline 24 & 1 & 4,37 & 1 & 6,91 & $-0,08$ \\
\hline 25 & 3 & 2,94 & 2 & 5,61 & $-0,06$ \\
\hline 26 & 0 & 0,18 & 0 & $-0,60$ & $-0,03$ \\
\hline 27 & 2 & 2,12 & -1 & 1,98 & 0,25 \\
\hline 28 & 1 & 2,36 & 1 & 5,03 & $-0,05$ \\
\hline 29 & 2 & 1,52 & 2 & 4,63 & 0,16 \\
\hline 30 & 1 & 2,10 & 2 & 6,04 & 0,24 \\
\hline 31 & -1 & $-3,71$ & -3 & $-4,80$ & 0,14 \\
\hline 32 & 5 & 6,27 & 8 & 12,62 & 0,13 \\
\hline 33 & 0 & $-0,47$ & 0 & $-3,69$ & 0,25 \\
\hline 34 & 0 & 0,73 & 2 & $-0,93$ & 0,21 \\
\hline 35 & 1 & $-1,16$ & 3 & $-1,38$ & $-0,13$ \\
\hline 36 & 0 & 1,93 & -1 & 2,09 & 0,10 \\
\hline 37 & 2 & 0,30 & 0 & 0,09 & $-0,01$ \\
\hline 38 & 6 & 3,72 & 10 & 4,57 & 0,32 \\
\hline 39 & 4 & 7,91 & 8 & 10,21 & 0,06 \\
\hline 40 & 0 & 0,90 & 0 & 0,86 & 0,02 \\
\hline 41 & 5 & 4,33 & 8 & 1,53 & 0,41 \\
\hline 42 & 5 & 8,60 & 7 & 11,93 & 0,35 \\
\hline 43 & 1 & 2,28 & 2 & 2,06 & 0,06 \\
\hline 44 & 0 & $-1,51$ & 0 & $-3,35$ & 0,13 \\
\hline 45 & 1 & 2,05 & 3 & 4,87 & $-0,15$ \\
\hline MEDIA $^{1 \mathrm{a}}$ & 1 & 2,03 & 2 & 2,44 & 0,07 \\
\hline
\end{tabular}

${ }^{1}$ Alteração média do caráter na população $F_{3: 2[4]}$ selecionada $=\bar{\mu}_{\mathrm{c}} \mathrm{F}_{3: 2[4]}$ selecionada $-\mu_{\mathrm{c}} \mathrm{F}_{3: 2[4]}$ original, com c = NDF, APF, NDM, APM, VA.

${ }^{2}$ Para identificar os caracteres, consultar Apêndice 1. ${ }^{3}$ Para identificar os cruzamentos ver Apêndice 6. 
Tabela 38 VA + PG: Ganho genético em g/planta $(\Delta \mathrm{gr})$ e percentual $(\Delta \mathrm{Gr} \%)$, obtidos em $\mathbf{F}_{3: 2[4]}$, pela seleção de plantas $F_{2[4]}$, com base no Valor Agronômico e Produtividade de Grãos ${ }^{2}$; número de plantas $(\mathrm{Np})$ e média da geração $\mathrm{F}_{3: 2}(\bar{\mu} p)$, número de plantas $\mathrm{F}_{2[4]}: \mathrm{F}_{3: 2[4]}$ selecionadas (Ns), média da população $F_{3: 2[4]}$ selecionada $\left(\mu \mathrm{s}^{1,2}\right)$ e percentual da população selecionado (\%s). Soja, cruzamentos quádruplos. Maracaí-SP (semeadura em 02/12/93).

\begin{tabular}{|c|c|c|c|c|c|c|c|}
\hline POPULAÇĀ' & $\mathrm{Np}$ & $\bar{\mu} \mathrm{p}(\mathrm{g} / \mathrm{pl})$ & $\overline{\mathrm{Ns}}$ & $\bar{\mu} \mathrm{s}^{1,2}(\mathrm{~g} / \mathrm{pl})$ & $\% s$ & $\Delta \mathrm{GT}$ & $\Delta \mathrm{Gr} \%$ \\
\hline$T$ & 41 & 48,30 & 10 & 41,19 & 24 & $-7,11$ & $-14,73$ \\
\hline 2 & 35 & 49,19 & 9 & 47,25 & 26 & $-1,94$ & $-3,95$ \\
\hline 3 & 33 & 73,61 & 13 & 63,52 & 39 & $-10,09$ & $-13,71$ \\
\hline 4 & 38 & 53,97 & 10 & 54,67 & 26 & 0,70 & 1,30 \\
\hline 5 & 41 & 48,66 & 7 & 54,46 & 17 & 5,80 & 11,93 \\
\hline 6 & 36 & 72,36 & 14 & 70,70 & 39 & $-1,66$ & $-2,30$ \\
\hline 7 & 34 & 58,62 & 6 & 59,18 & 18 & 0,56 & 0,95 \\
\hline 8 & 37 & 63,56 & 7 & 62,11 & 19 & $-1,45$ & $-2,28$ \\
\hline 9 & 35 & 63,82 & 7 & 56,44 & 20 & $-7,38$ & $-11,56$ \\
\hline 10 & 37 & 56,86 & 7 & 50,47 & 19 & $-6,39$ & $-11,25$ \\
\hline 11 & 40 & 58,60 & 5 & 49,95 & 13 & $-8,65$ & $-14,76$ \\
\hline 12 & 42 & 54,01 & 17 & 64,27 & 40 & 10,26 & 18,99 \\
\hline 13 & 42 & 52,45 & 9 & 57,04 & 21 & 4,59 & 8,75 \\
\hline 14 & 42 & 55,76 & 9 & 57,25 & 21 & 1,49 & 2,67 \\
\hline 15 & 35 & 61,19 & 6 & 65,26 & 17 & 4,07 & 6,65 \\
\hline 16 & 41 & 57,53 & 17 & 59,94 & 41 & 2,41 & 4,19 \\
\hline 17 & 36 & 40,56 & 5 & 45,55 & 14 & 4,99 & $12,3]$ \\
\hline 18 & 41 & 56,17 & 5 & 69,16 & 12 & 12,99 & 23,12 \\
\hline 19 & 46 & 66,49 & 17 & 57,70 & 37 & $-8,79$ & $-13,22$ \\
\hline 20 & 38 & 64,33 & 9 & 73,70 & 24 & 9,37 & 14,57 \\
\hline 21 & 39 & 73,89 & 21 & 81,10 & 54 & 7,21 & 9,75 \\
\hline 22 & 40 & 66,95 & 17 & 88,02 & 43 & 21,07 & 31,46 \\
\hline 23 & 36 & 73,77 & 20 & 80,82 & 56 & 7,05 & 9,56 \\
\hline 24 & 37 & 63,87 & 6 & 74,23 & 16 & 10,36 & 16,22 \\
\hline 25 & 36 & 45,65 & 4 & 36,25 & 11 & $-9,40$ & $-20,60$ \\
\hline 26 & 35 & 48,56 & 12 & 49,24 & 34 & 0,68 & 1,41 \\
\hline 27 & 41 & 59,67 & 10 & 66,07 & 24 & 6,40 & 10,73 \\
\hline 28 & 41 & 59,36 & 10 & 61,17 & 24 & 1,81 & 3,05 \\
\hline 29 & 38 & 68,79 & 9 & 66,95 & 24 & $-1,84$ & $-2,67$ \\
\hline 30 & 39 & 56,92 & 3 & 68,85 & 8 & 11,93 & 20,95 \\
\hline 31 & 31 & 50,39 & 3 & 71,80 & 10 & 21,41 & 42,49 \\
\hline 32 & 42 & 56,98 & 3 & 78,67 & 7 & 21,69 & 38,07 \\
\hline 33 & 41 & 57,74 & 12 & 64,43 & 29 & 6,69 & 11,58 \\
\hline 34 & 43 & 70,57 & 12 & 74,76 & 28 & 4,19 & 5,94 \\
\hline 35 & 42 & 60,97 & 11 & 57,90 & 26 & $-3,07$ & $-5,04$ \\
\hline 36 & 37 & 60,08 & 11 & 62,67 & 30 & 2,59 & 4,31 \\
\hline 37 & 36 & 54,62 & 8 & 70,49 & 22 & 15,87 & 29,06 \\
\hline 38 & 43 & 45,41 & 5 & 49,02 & 12 & 3,61 & 7,96 \\
\hline 39 & 33 & 62,21 & 5 & 59,68 & 15 & $-2,53$ & $-4,07$ \\
\hline 40 & 44 & 55,28 & 12 & 60,73 & 27 & 5,45 & 9,85 \\
\hline 41 & 43 & 70,29 & 1 & 125,96 & 2 & 55,67 & 79,20 \\
\hline 42 & 42 & 55,50 & 4 & 59,19 & 10 & 3,69 & 6,64 \\
\hline 43 & 43 & 53,04 & 12 & 55,41 & 28 & 2,37 & 4,47 \\
\hline 44 & 39 & 59,86 & 3 & 68,17 & 8 & 8,31 & 13,88 \\
\hline 45 & 45 & 57,99 & 5 & 48,10 & 11 & $-9,89$ & $-17,06$ \\
\hline MEDIA $^{4}$ & 39 & 58,74 & 9 & 63,61 & 23 & 4,87 & 8,29 \\
\hline
\end{tabular}

${ }^{1}$ Seleção de plantas $F_{2[4]}$ com VA $\geq 4$ (boas e excelentes) e ${ }^{2} P G>141$ g/planta .

${ }^{3}$ Para identificar os cruzamentos que originaram estas populações, consultar o Apêndice 6.

${ }^{4}$ Médias de produtividade ponderadas pelo número de plantas da população (Np e Ns). 
Tabela 39 VA + PG: Alterações ${ }^{1}$ ocorridas nas médias de cinco caracteres ${ }^{2}$ das populações $\mathbf{F}_{3: 2[4]}$, proporcionadas pela seleção em $F_{2[4]}$, para o caráter Produtividade de Grãos ${ }^{3}(\mathrm{PG})$ e Valor Agronômico ${ }^{3}$ (VA). Soja, cruzamentos quádruplos. Maracaí -SP. (semeadura $02 / 12 / 93$ ).

\begin{tabular}{|c|c|c|c|c|c|}
\hline POPULAÇÃO & NDF & $\overline{\mathrm{APF}}$ & $\overline{\mathrm{NDM}}$ & APM & $\mathrm{VA}$ \\
\hline ] & 7 & 4,37 & 17 & 6,07 & $\overline{0,20}$ \\
\hline 2 & 3 & 5,00 & 5 & 4,51 & 0,01 \\
\hline 3 & 2 & 2,60 & 4 & 3,55 & $-0,33$ \\
\hline 4 & 1 & 4,25 & 4 & 6,89 & 0,31 \\
\hline 5 & 0 & 6,49 & -3 & 8,32 & 0,08 \\
\hline 6 & 0 & $-0,10$ & -2 & $-1,22$ & $-0,06$ \\
\hline 7 & 2 & 1,70 & 4 & 4,15 & 0,18 \\
\hline 8 & 8 & 18,46 & 15 & 22,97 & $-0,18$ \\
\hline 9 & 14 & 14,00 & 24 & $-1,97$ & $-0,06$ \\
\hline 10 & 6 & 8,92 & 17 & 13,31 & 0,46 \\
\hline 11 & -1 & 0,70 & 4 & $-7,28$ & $-0,13$ \\
\hline 12 & 0 & 2,08 & -1 & $-1,98$ & 0,38 \\
\hline 13 & 1 & 1,15 & 3 & 3,28 & 0,29 \\
\hline 14 & 2 & 7,63 & 2 & 10,26 & 0,54 \\
\hline 15 & -1 & 1,60 & -6 & 3,36 & $-0,23$ \\
\hline 16 & -1 & $-0,11$ & -3 & 0,15 & 0,01 \\
\hline 17 & 7 & 18,58 & 9 & 18,30 & $-0,10$ \\
\hline 18 & 2 & 2,05 & -2 & 0,80 & $-0,18$ \\
\hline 19 & 1 & 1,04 & 3 & 0,28 & $-0,39$ \\
\hline 20 & 4 & 7,61 & 11 & 9,22 & 0,11 \\
\hline 21 & 5 & 7,85 & 6 & 9,48 & 0,17 \\
\hline 22 & 1 & 4,24 & 3 & 7,18 & 0,53 \\
\hline 23 & 1 & 1,36 & 1 & $-0,68$ & 0,11 \\
\hline 24 & 5 & 8,32 & 8 & 7,32 & 0,25 \\
\hline 25 & 5 & 3,25 & 6 & 13,89 & $-0,31$ \\
\hline 26 & 0 & $-1,67$ & 1 & $-3,77$ & $-0,11$ \\
\hline 27 & 1 & 1,00 & -3 & 3,80 & 0,49 \\
\hline 28 & 2 & 5,12 & 5 & 8,01 & $-0,28$ \\
\hline 29 & 0 & 1,15 & 0 & 9,52 & 0,16 \\
\hline 30 & 4 & 9,74 & 7 & 12,46 & 0,05 \\
\hline 31 & -1 & $-1,42$ & 6 & $-2,06$ & 0,05 \\
\hline 32 & 4 & 4,97 & 5 & 9,24 & 0,38 \\
\hline 33 & 2 & 0,24 & 1 & $-0,26$ & 0,46 \\
\hline 34 & 1 & $-0,60$ & 4 & $-4,15$ & 0,21 \\
\hline 35 & 4 & 3,52 & 8 & 1,71 & 0,05 \\
\hline 36 & -3 & $-3,63$ & -9 & $-2,61$ & 0,19 \\
\hline 37 & -5 & $-3,66$ & -8 & $-7,31$ & 0,44 \\
\hline 38 & 8 & 7,12 & 17 & 6,30 & 0,45 \\
\hline 39 & 1 & 4,09 & 8 & 11,01 & 0,04 \\
\hline 40 & 1 & 4,01 & 4 & 4,19 & 0,36 \\
\hline 41 & 8 & 3,33 & 12 & 1,53 & 1,24 \\
\hline 42 & 6 & 6,73 & 5 & 5,77 & 0,26 \\
\hline 43 & 4 & 4,91 & 6 & 6,96 & 0,43 \\
\hline 44 & -1 & $-4,84$ & -9 & $-6,39$ & $-0,08$ \\
\hline 45 & -1 & $-8,42$ & -1 & $-4,33$ & $-0,82$ \\
\hline MEDIA $^{5}$ & 2 & 3,29 & 3 & 3,65 & 0,14 \\
\hline
\end{tabular}

${ }^{1}$ Alteração média do caráter na população $F_{3: 2[4]}$ selecionada $=\bar{\mu}_{c} F_{3: 2[4]}$ selec. $-\mu_{c} F_{3: 2[4]}$ original, com $\mathrm{c}=\mathrm{NDF}, \mathrm{APF}, \mathrm{NDM}, \mathrm{APM}, \mathrm{VA}$.

${ }^{2}$ Para identificação dos caracteres, consultar Apêndice 1.

${ }^{3}$ Seleção em $F_{2[4]}$ de plantas com $P G>141$ g/planta e VA $\geq 4$.

${ }^{4}$ Para identificar os cruzamentos consultar o Apêndice 6.

${ }^{5}$ Médias ponderadas pelo número de plantas selecionadas. 
Tabela 40 NDM + PG: Ganho genético em g/planta $(\Delta g r)$ e percentual $(\Delta \mathrm{Gr} \%)$, obtidos em $\mathbf{F}_{3: 2[4]}$, pela seleção de plantas $F_{2[4]}$, com base no Número de Dias para a Maturidade ${ }^{\mathrm{i}} \mathrm{e}$ Produtividade de Grãos ${ }^{2}$. Número de plantas $(\mathrm{Np})$ e médias da geração $\mathrm{F}_{3: 2[4]}(\bar{\mu} \mathrm{p})$, número de plantas $\mathrm{F}_{2[4]}: \mathrm{F}_{3: 2[4]}$ selecionadas $(\mathrm{Ns})$, média da população $\mathrm{F}_{3: 2[4]}$ selecionada $\left(\bar{\mu}^{1}\right)$ e percentual da população selecionado (\%s). Soja, Maracaí-SP (sem. 02/12/93).

\begin{tabular}{|c|c|c|c|c|c|c|c|}
\hline POPULAÇÃO ${ }^{3}$ & $\mathrm{~Np}$ & $\overline{\mu p}(\mathrm{~g} / \mathrm{pl})$ & Ns & $\overline{\mu s}(\mathrm{~g} / \mathrm{pl})$ & $\% s$ & $\Delta \mathrm{Gr}$ & $\Delta G \%$ \\
\hline 1 & 41 & 48,30 & 5 & 63,02 & 12 & 14,72 & 30,48 \\
\hline 2 & 35 & 49,19 & 9 & 47,25 & 26 & $-1,94$ & $-3,94$ \\
\hline 3 & 33 & 73,61 & 13 & 64,85 & 39 & $-8,77$ & $-11,91$ \\
\hline 4 & 38 & 53,97 & 10 & 54,67 & 26 & 0,70 & 1,30 \\
\hline 5 & 41 & 48,66 & 4 & 59,39 & 10 & 10,73 & 22,05 \\
\hline 6 & 36 & 72,36 & 10 & 74,62 & 28 & 2,26 & 3,12 \\
\hline 7 & 34 & 58,62 & 6 & 59,18 & 18 & 0,56 & 0,96 \\
\hline 8 & 37 & 63,56 & 6 & 61,48 & 16 & $-2,08$ & $-3,27$ \\
\hline 9 & 35 & 63,82 & 4 & 70,42 & 11 & 6,60 & 10,34 \\
\hline 10 & 37 & 56,86 & 6 & 60,91 & 16 & 4,05 & 7,12 \\
\hline 11 & 40 & 58,60 & 5 & 54,15 & 13 & $-4,45$ & $-7,59$ \\
\hline 12 & 42 & 54,01 & 16 & 67,32 & 38 & 13,31 & 24,64 \\
\hline 13 & 42 & 52,45 & 9 & 57,04 & 21 & 4,59 & 8,75 \\
\hline 14 & 42 & 55,76 & 7 & 65,13 & 17 & 9,37 & 16,80 \\
\hline 15 & 35 & 61,19 & 4 & 72,23 & 11 & 11,04 & 18,04 \\
\hline 16 & 41 & 57,53 & 16 & 60,03 & 39 & 2,50 & 4,35 \\
\hline 17 & 36 & 40,56 & 1 & 94,66 & 3 & 54,10 & 133,38 \\
\hline 18 & 41 & 56,17 & 7 & 61,61 & 17 & 5,44 & 9,68 \\
\hline 19 & 46 & 66,49 & 17 & 57,70 & 37 & $-8,79$ & $-13,22$ \\
\hline 20 & 38 & 64,33 & 10 & 75,83 & 26 & 11,50 & 17,88 \\
\hline 21 & 39 & 73,89 & 19 & 85,11 & 49 & 11,22 & 15,18 \\
\hline 22 & 40 & 66,95 & 19 & 87,06 & 48 & 20,11 & 30,04 \\
\hline 23 & 36 & 73,77 & 21 & 79,25 & 58 & 5,48 & 7,43 \\
\hline 24 & 37 & 63,87 & 8 & 72,93 & 22 & 9,06 & 14,19 \\
\hline 25 & 36 & 45,65 & 4 & 36,25 & 11 & $-9,40$ & $-20,59$ \\
\hline 26 & 35 & 48,56 & 12 & 49,24 & 34 & 0,68 & 1,40 \\
\hline 27 & 41 & 59,67 & 10 & 66,07 & 24 & 6,40 & 10,73 \\
\hline 28 & $4 I$ & 59,36 & 10 & 61,17 & 24 & 1,81 & 3,05 \\
\hline 29 & 38 & 68,79 & 11 & 65,00 & 29 & $-3,79$ & $-5,51$ \\
\hline 30 & 39 & 56,92 & 5 & 68,99 & 13 & 12,07 & 21,21 \\
\hline 31 & 31 & 50,39 & 3 & 71,80 & 10 & 21,41 & 42,49 \\
\hline 32 & 42 & 56,98 & 4 & 72,47 & 10 & 15,49 & 27,18 \\
\hline 33 & 41 & 57,74 & 12 & 64,43 & 29 & 6,69 & 11,59 \\
\hline 34 & 43 & 70,57 & 13 & 75,58 & 30 & 5,01 & 7,10 \\
\hline 35 & 42 & 60,97 & 11 & 57,90 & 26 & $-3,07$ & $-5,04$ \\
\hline 36 & 37 & 60,08 & 11 & 62,67 & 30 & 2,59 & 4,31 \\
\hline 37 & 36 & 54,62 & 8 & 70,49 & 22 & 15,87 & 29,06 \\
\hline 38 & 43 & 45,41 & 8 & 47,56 & 19 & 2,15 & 4,73 \\
\hline 39 & 33 & 62,21 & 5 & 59,68 & 15 & $-2,53$ & $-4,07$ \\
\hline 40 & 44 & 55,28 & 12 & 60,73 & 27 & 5,45 & 9,86 \\
\hline 41 & 43 & 70,29 & 3 & 83,90 & 7 & 13,61 & 19,36 \\
\hline 42 & 42 & 55,50 & 5 & 51,08 & 12 & $-4,42$ & $-7,96$ \\
\hline 43 & 43 & 53,04 & 12 & 55,41 & 28 & 2,37 & 4,47 \\
\hline 44 & 39 & 59,86 & 3 & 68,17 & 8 & 8,31 & 13,88 \\
\hline 45 & 45 & 57,99 & 5 & 48,10 & 11 & $-9,89$ & $-17,05$ \\
\hline MÉDIA $^{4}$ & 39 & 58,74 & 9 & 65,36 & 23 & 6,62 & 11,27 \\
\hline
\end{tabular}

${ }^{1}$ Seleção de plantas $F_{2[4]}$ com NDM $\leq 162 \mathrm{e}^{2}$ com $P G>141 \mathrm{~g} /$ planta.

${ }^{3}$ Para identificação dos cruzamentos, consultar o Apêndice 6 .

${ }^{4}$ Médias de produtividade ponderadas pelo número de plantas da população (Np e Ns) 
Tabela 41 NDM + PG: Diferenças entre as médias de cinco caracteres ${ }^{1}$ das populações $\mathbf{F}_{3: 2[4]}$, selecionada e original (selec. - orig. ), obtidas após seleção em $F_{2[4]}$, para Produtividade de Grãos $^{2}$ (PG) e Número de Dias para a Maturidade ${ }^{3}$ (NDM). Soja, cruzamentos Quádruplos, Maracai - SP (semeadura 02/12/93).

\begin{tabular}{|c|c|c|c|c|c|}
\hline POPULAÇAO $^{7-}$ & NDF & APF & NDM & APM & VA \\
\hline$T$ & -3 & 5,27 & -13 & 7,17 & 1,00 \\
\hline 2 & 3 & 5,00 & 5 & 4,51 & 0,01 \\
\hline 3 & I & $-1,25$ & 0 & $-1,53$ & $-0,25$ \\
\hline 4 & 1 & 4,25 & 4 & 6,89 & 0,31 \\
\hline 5 & -12 & $-0,65$ & -29 & 0,25 & 0,22 \\
\hline 6 & 0 & $-0,79$ & -5 & $-2,18$ & 0,04 \\
\hline 7 & 2 & 1,70 & 4 & 4,15 & 0,18 \\
\hline 8 & 4 & 12,53 & 6 & 17,64 & $-0,22$ \\
\hline 9 & 2 & $-4,86$ & -2 & $-12,83$ & $-0,38$ \\
\hline 10 & 1 & 2,75 & 2 & 4,17 & 0,29 \\
\hline 11 & -3 & $-2,90$ & -7 & $-7,08$ & 0,27 \\
\hline 12 & -1 & 0,03 & -4 & $-4,41$ & 0,44 \\
\hline 13 & 1 & 1,15 & 3 & 3,28 & 0,81 \\
\hline 14 & 1 & 7,95 & -4 & 11,93 & 0,84 \\
\hline 15 & -2 & $-5,23$ & -6 & $-2,72$ & $-0,06$ \\
\hline 16 & -3 & $-3,43$ & -5 & $-3,63$ & 0,07 \\
\hline 17 & -16 & 0,58 & -22 & $-8,50$ & 1,50 \\
\hline 18 & 1 & $-0,01$ & -4 & $-7,06$ & $-0,21$ \\
\hline 19 & 1 & 1,04 & 3 & 0,28 & $-0,39$ \\
\hline 20 & 2 & 5,80 & 3 & 7,10 & 0,20 \\
\hline 21 & 3 & 3,82 & 3 & 5,42 & 0,35 \\
\hline 22 & 0 & 4,52 & 2 & 7,46 & 0,53 \\
\hline 23 & 1 & 1,16 & 0 & $-1,09$ & 0,09 \\
\hline 24 & 3 & 8,70 & 8 & 12,65 & $-0,05$ \\
\hline 25 & 5 & 3,25 & 6 & 13,89 & $-0,31$ \\
\hline 26 & 0 & $-1,67$ & 1 & $-3,77$ & $-0,11$ \\
\hline 27 & 1 & 1,00 & -3 & 3,80 & 0,49 \\
\hline 28 & 2 & 5,12 & 5 & 8,01 & $-0,28$ \\
\hline 29 & -1 & $-1,65$ & -2 & 1,27 & $-0,04$ \\
\hline 30 & 6 & 13,01 & 6 & 17,99 & 0,25 \\
\hline 31 & -1 & $-1,42$ & 6 & $-2,06$ & 0,05 \\
\hline 32 & 2 & 5,39 & 0 & 7,49 & 0,38 \\
\hline 33 & 2 & 0,24 & 1 & $-0,26$ & 0,46 \\
\hline 34 & 0 & $-1,69$ & 3 & $-3,83$ & 0,13 \\
\hline 35 & 4 & 3,52 & 8 & 1,71 & 0,05 \\
\hline 36 & -3 & $-3,63$ & -9 & $-2,61$ & 0,19 \\
\hline 37 & -5 & $-3,66$ & -8 & $-7,31$ & 0,44 \\
\hline 38 & 4 & 5,87 & 7 & 6,33 & 0,28 \\
\hline 39 & 1 & 4,09 & 8 & 11,01 & 0,04 \\
\hline 40 & 1 & 4,01 & 4 & 4,19 & 0,36 \\
\hline 41 & 1 & $-2,67$ & -7 & 8,86 & 0,24 \\
\hline 42 & 3 & 2,08 & 1 & 1,52 & $-0,04$ \\
\hline 43 & 4 & 4,91 & 6 & 6,96 & 0,43 \\
\hline 44 & -1 & $-4,84$ & -9 & $-6,39$ & $-0,08$ \\
\hline 45 & -1 & $-8,42$ & -1 & $-4,33$ & $-0,82$ \\
\hline MEDIA ${ }^{5}$ & 1 & 1,66 & 0 & 2,14 & 0,17 \\
\hline
\end{tabular}

'Tlteração média do caráter na população $F_{3: 2[4]}$ selecionada $=\bar{\mu}_{c} F_{3: 2[4]}$ selec. $-\bar{\mu}_{c} F_{3: 2[4]}$ original, com c = NDF, APF, NDM, APM, VA.

${ }^{1}$ Para identificação dos caracteres, consultar o Apêndice 1.

${ }^{2}$ Seleção em $F_{2}$ de plantas com $P G>141$ g/planta $e^{3} \mathrm{NDM} \leq 162$.

${ }^{4}$ Para identificar os cruzamentos consultar o Apêndice 6.

${ }^{5}$ Médias ponderadas pelo número de plantas selecionadas. 
Tabela 42 NDM + VA + PG: Ganho genético em g/planta $(\Delta \mathrm{gr})$ e percentual $(\Delta \mathrm{Gr} \%)$, obtidos em $F_{3: 2[4]}$, pela seleção plantas $F_{2[4]}$, com base no Número de Dias para a Maturidade ${ }^{1}$, Valor agronômico ${ }^{2}$ e Produtividade de Grãos ${ }^{3}$. Número de plantas $(\mathrm{Np})$ e média da geração $\mathrm{F}_{3: 2[4]}$ ( $\underline{\mu} \mathrm{p}$ ), número de plantas $\mathrm{F}_{2[4]}: \mathrm{F}_{3: 2[4]}$ selecionadas (Ns), média da população $\mathrm{F}_{3: 2[4]}$ selecionada $\left(\overline{\mu s}^{1}\right)$ e percentual da pop. selecionado (\%s). Soja, Maracai - SP (sem. 02/12/93).

\begin{tabular}{|c|c|c|c|c|c|c|c|}
\hline POPULAÇÃO & $\mathrm{Np}$ & $\mu \mathrm{p}(\mathrm{g} / \mathrm{pl})$ & Ns & $\overline{\mu s}(\mathrm{~g} / \mathrm{pl})$ & $\%$ & $\Delta \mathrm{Gr}$ & $\Delta \mathrm{Gr} \%$ \\
\hline 1 & 41 & 48,30 & 4 & 68,93 & 10 & 20,63 & 42,71 \\
\hline 2 & 35 & 49,19 & 9 & 47,25 & 26 & $-1,94$ & $-3,95$ \\
\hline 3 & 33 & 73,61 & 12 & 66,17 & 36 & $-7,44$ & $-10,10$ \\
\hline 4 & 38 & 53,97 & 10 & 54,67 & 26 & 0,70 & 1,30 \\
\hline 5 & 41 & 48,66 & 4 & 59,39 & 10 & 10,73 & 22,05 \\
\hline 6 & 36 & 72,36 & 10 & 74,62 & 28 & 2,26 & 3,12 \\
\hline 7 & 34 & 58,62 & 6 & 59,18 & 18 & 0,56 & 0,95 \\
\hline 8 & 37 & 63,56 & 6 & 61,48 & 16 & $-2,08$ & $-3,28$ \\
\hline 9 & 35 & 63,82 & 0 & 63,82 & 0 & 0,00 & 0,00 \\
\hline 10 & 37 & 56,86 & 5 & 57,46 & 14 & 0,60 & 1,06 \\
\hline 11 & 40 & 58,60 & 4 & 56,12 & 10 & $-2,48$ & $-4,23$ \\
\hline 12 & 42 & 54,01 & 16 & 67,32 & 38 & 13,31 & 24,65 \\
\hline 13 & 42 & 52,45 & 9 & 57,04 & 21 & 4,59 & 8,75 \\
\hline 14 & 42 & 55,76 & 7 & 65,13 & 17 & 9,37 & 16,80 \\
\hline 15 & 35 & 61,19 & 4 & 72,23 & 11 & 11,04 & 18,03 \\
\hline 16 & 41 & 57,53 & 16 & 60,03 & 39 & 2,50 & 4,35 \\
\hline 17 & 36 & 40,56 & 1 & 94,66 & 3 & 54,10 & 133,38 \\
\hline 18 & 41 & 56,17 & 5 & 69,16 & 12 & 12,99 & 23,12 \\
\hline 19 & 46 & 66,49 & 17 & 57,70 & 37 & $-8,79$ & $-13,22$ \\
\hline 20 & 38 & 64,33 & 8 & 76,15 & 21 & 11,82 & 18,37 \\
\hline 21 & 39 & 73,89 & 18 & 87,02 & 46 & 13,13 & 17,77 \\
\hline 22 & 40 & 66,95 & 17 & 88,02 & 43 & 21,07 & 31,46 \\
\hline 23 & 36 & 73,77 & 20 & 80,82 & 56 & 7,05 & 9,56 \\
\hline 24 & 37 & 63,87 & 6 & 74,23 & 16 & 10,36 & 16,22 \\
\hline 25 & 36 & 45,65 & 4 & 36,25 & 11 & $-9,40$ & $-20,60$ \\
\hline 26 & 35 & 48,56 & 12 & 49,24 & 34 & 0,68 & 1,41 \\
\hline 27 & 41 & 59,67 & 10 & 66,07 & 24 & 6,40 & 10,73 \\
\hline 28 & 41 & 59,36 & 10 & 61,17 & 24 & 1,81 & 3,05 \\
\hline 29 & 38 & 68,79 & 9 & 66,95 & 24 & $-1,84$ & $-2,67$ \\
\hline 30 & 39 & 56,92 & 3 & 68,85 & 8 & 11,93 & 20,95 \\
\hline 31 & 31 & 50,39 & 3 & 71,80 & 10 & 21,41 & 42,49 \\
\hline 32 & 42 & 56,98 & 3 & 78,67 & 7 & 21,69 & 38,07 \\
\hline 33 & 41 & 57,74 & 12 & 64,43 & 29 & 6,69 & 11,58 \\
\hline 34 & 43 & 70,57 & 12 & 74,76 & 28 & 4,19 & 5,94 \\
\hline 35 & 42 & 60,97 & 11 & 57,90 & 26 & $-3,07$ & $-5,04$ \\
\hline 36 & 37 & 60,08 & 11 & 62,67 & 30 & 2,59 & 4,31 \\
\hline 37 & 36 & 54,62 & 8 & 70,49 & 22 & 15,87 & 29,06 \\
\hline 38 & 43 & 45,41 & 5 & 49,02 & 12 & 3,61 & 7,96 \\
\hline 39 & 33 & 62,21 & 5 & 59,68 & 15 & $-2,53$ & $-4,07$ \\
\hline 40 & 44 & 55,28 & 12 & 60,73 & 27 & 5,45 & 9,85 \\
\hline 41 & 43 & 70,29 & 1 & 125,96 & 2 & 55,67 & 79,20 \\
\hline 42 & 42 & 55,50 & 4 & 59,19 & 10 & 3,69 & 6,64 \\
\hline 43 & 43 & 53,04 & 12 & 55,41 & 28 & 2,37 & 4,47 \\
\hline 44 & 39 & 59,86 & 3 & 68,17 & 8 & 8,31 & 13,88 \\
\hline 45 & 45 & 57,99 & 5 & 48,10 & 11 & $-9,89$ & $-17,06$ \\
\hline MÉDIA & 39 & 58,74 & 8 & 65,82 & 21 & 7,08 & 12,05 \\
\hline
\end{tabular}

${ }^{1}$ Seleção de plantas $F_{2}$ com NDM $\leq 162,{ }^{2}$ VA $\geq 4$ (bom e excelente) e ${ }^{3} P G>141$ g/ planta ${ }^{4}$ Para identificação dos cruzamentos consultar o Apêndice 6.

${ }^{5}$ Médias de produtividade ponderadas pelo número de plantas da população (Np e Ns). 
Tabela 43 NDM + VA + PG : Alteraçōes $^{1}$ ocorridas nas médias de cinco caracteres $^{2}$ das populaçōes $F_{3: 2[4]}$, proporcionadas pela seleção em $F_{2[4]}$, para os caracteres Número de Dias para a Maturidade (NDM) ${ }^{3}$, Valor Agronômico ${ }^{4}$ (VA) e Produtividade de grãos ${ }^{5}$ (PG). Soja, cruzamentos quádruplos. Maracaí - SP (semeadura 02/12/93).

\begin{tabular}{|c|c|c|c|c|c|}
\hline POPULAÇÃ ${ }^{6}$ & NDF & $\overline{\mathrm{APF}}$ & NDM & APM & VA \\
\hline 1 & -8 & $-2,38$ & -21 & $-3,38$ & 1,10 \\
\hline 2 & 3 & 5,00 & 5 & 4,51 & 0,01 \\
\hline 3 & 2 & $-0,15$ & 1 & 1,24 & $-0,29$ \\
\hline 4 & 1 & 4,25 & 4 & 6,89 & 0,31 \\
\hline 5 & -12 & $-0,65$ & -29 & 0,25 & 0,22 \\
\hline 6 & 0 & $-0,79$ & -5 & $-2,18$ & 0,04 \\
\hline 7 & 2 & 1,70 & 4 & 4,15 & 0,18 \\
\hline 8 & 4 & 12,53 & 6 & 17,64 & $-0,22$ \\
\hline 9 & 0 & 0,00 & 0 & 0,00 & 0,00 \\
\hline 10 & 3 & 4,12 & 5 & 7,37 & 0,46 \\
\hline 11 & -5 & $-4,55$ & -10 & $-12,78$ & 0,02 \\
\hline 12 & -1 & 0,03 & -4 & $-4,41$ & 0,44 \\
\hline 13 & 1 & 1,15 & 3 & 3,28 & $-0,02$ \\
\hline 14 & 1 & 7,95 & -4 & 11,93 & 0,84 \\
\hline 15 & -2 & $-5,23$ & -6 & $-2,72$ & $-0,06$ \\
\hline 16 & -3 & $-3,43$ & -5 & $-3,63$ & 0,07 \\
\hline 17 & -16 & 0,58 & -22 & $-8,50$ & 1,50 \\
\hline 18 & 2 & 2,05 & -2 & 0,80 & $-0,18$ \\
\hline 19 & 1 & 1,04 & 3 & 0,28 & $-0,39$ \\
\hline 20 & 3 & 7,13 & 5 & 9,13 & 0,13 \\
\hline 21 & 4 & 5,23 & 4 & 6,72 & 0,42 \\
\hline 22 & 1 & 4,24 & 3 & 7,18 & 0,53 \\
\hline 23 & 1 & 1,36 & 1 & $-0,68$ & 0,11 \\
\hline 24 & 5 & 8,32 & 8 & 7,32 & 0,25 \\
\hline 25 & 5 & 3,25 & 6 & 13,89 & $-0,31$ \\
\hline 26 & 0 & $-1,67$ & 1 & $-3,77$ & $-0,11$ \\
\hline 27 & 1 & 1,00 & -3 & 3,80 & 0,49 \\
\hline 28 & 2 & 5,12 & 5 & 8,01 & $-0,28$ \\
\hline 29 & 0 & 1,15 & 0 & 9,52 & 0,16 \\
\hline 30 & 4 & 9,74 & 7 & 12,46 & 0,05 \\
\hline 31 & -1 & $-1,42$ & 6 & $-2,06$ & 0,05 \\
\hline 32 & 4 & 4,97 & 5 & 9,24 & 0,38 \\
\hline 33 & 2 & 0,24 & 1 & $-0,26$ & 0,46 \\
\hline 34 & l & $-0,60$ & 4 & $-4,15$ & 0,21 \\
\hline 35 & 4 & 3,52 & 8 & 1,71 & 0,05 \\
\hline 36 & -3 & $-3,63$ & -9 & $-2,61$ & 0,19 \\
\hline 37 & -5 & $-3,66$ & -8 & $-7,31$ & 0,44 \\
\hline 38 & 8 & 7,12 & 17 & 6,30 & 0,45 \\
\hline 39 & 1 & 4,09 & 8 & 11,01 & 0,04 \\
\hline 40 & 1 & 4,01 & 4 & 4,19 & 0,36 \\
\hline 41 & 8 & 3,33 & 12 & 1,53 & 1,24 \\
\hline 42 & 6 & 6,73 & 5 & 5,77 & 0,26 \\
\hline 43 & 4 & 4,91 & 6 & 6,96 & 0,43 \\
\hline 44 & -1 & $-4,84$ & -9 & $-6,39$ & $-0,08$ \\
\hline 45 & -1 & $-8,42$ & -1 & $-4,33$ & $-0,82$ \\
\hline MEDIA & 1 & 1,84 & 1 & 2,39 & 0,19 \\
\hline
\end{tabular}

${ }^{1}$ Alteração média do caráter na população $F_{3: 2[4]}$ selecionada $=\bar{\mu}_{c} F_{3: 2[4]}$ selec. $-\bar{\mu}_{\mathrm{c}} F_{3: 2[4]}$ original, com $\mathrm{c}=\mathrm{NDF}, \mathrm{APF}, \mathrm{NDM}, \mathrm{APM}, \mathrm{VA}$.

${ }^{2}$ Para identificação dos caracteres, consultar o Apêndice 1.

${ }^{3}$ Seleção em $F_{2[4]}$ de plantas com NDM $\leq 162,{ }^{4} \mathrm{VA} \geq 4$ (bom e excelente) e ${ }^{5} \mathrm{PG}>141 \mathrm{~g} /$ planta.

${ }^{6}$ Para identificar os cruzamentos, consultar o Apêndice 6.

${ }^{7}$ Módias ponderadas pelo número de plantas selecionadas. 
FIGURAS 


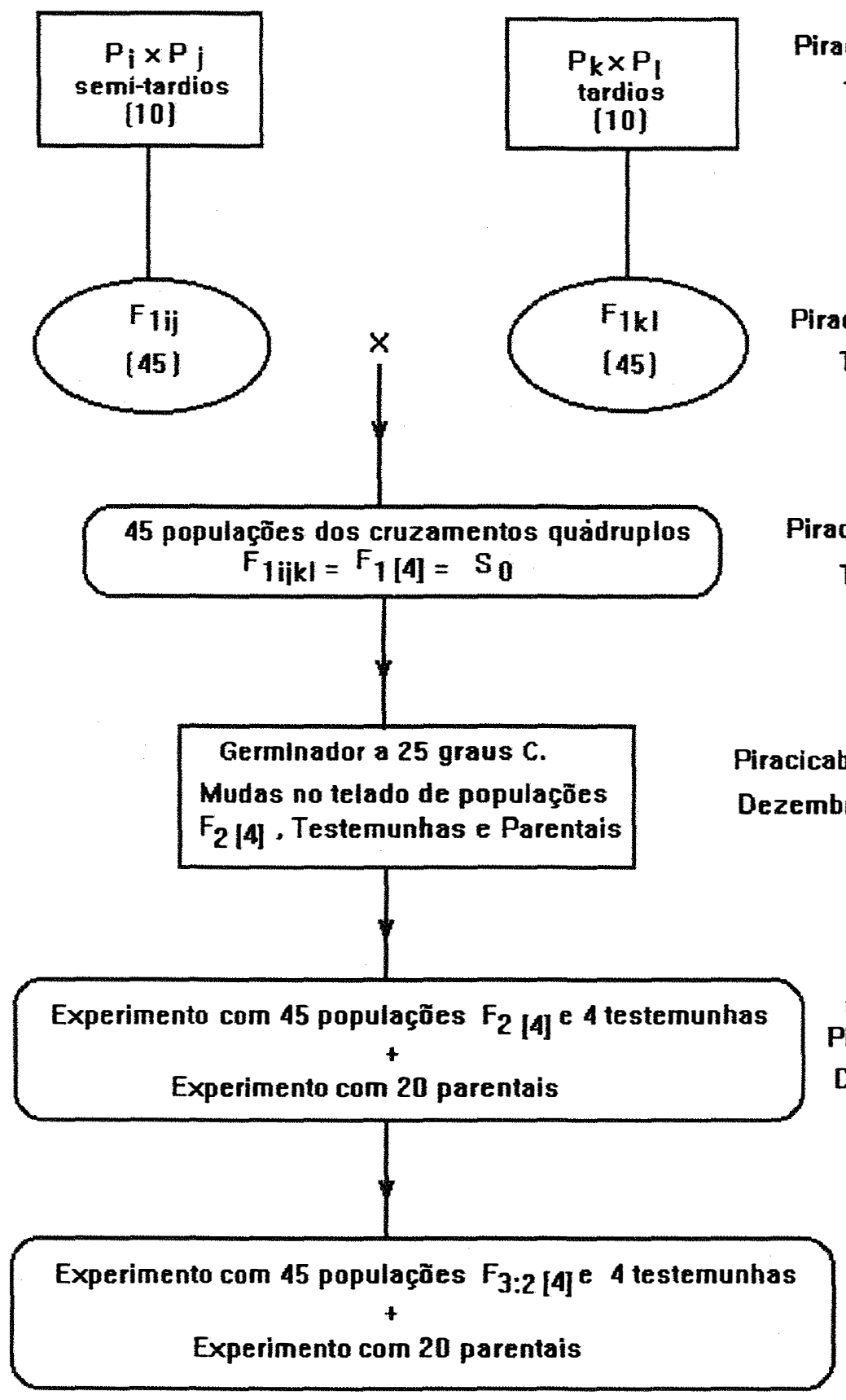

Campo-ESALQ

Piracicaba - $92 / 93$

Dezembro a Julho

Figura 1 Esquema de obtenção das 45 populações a partir de cruzamentos quádruplos de 10 parentais semi-tardios e 10 parentais tardios em soja e condução degerações segregantes em Piracicaba - SP (semeadura 04/12/92) e Maracaí - SP (semeadura 02/12/93). 


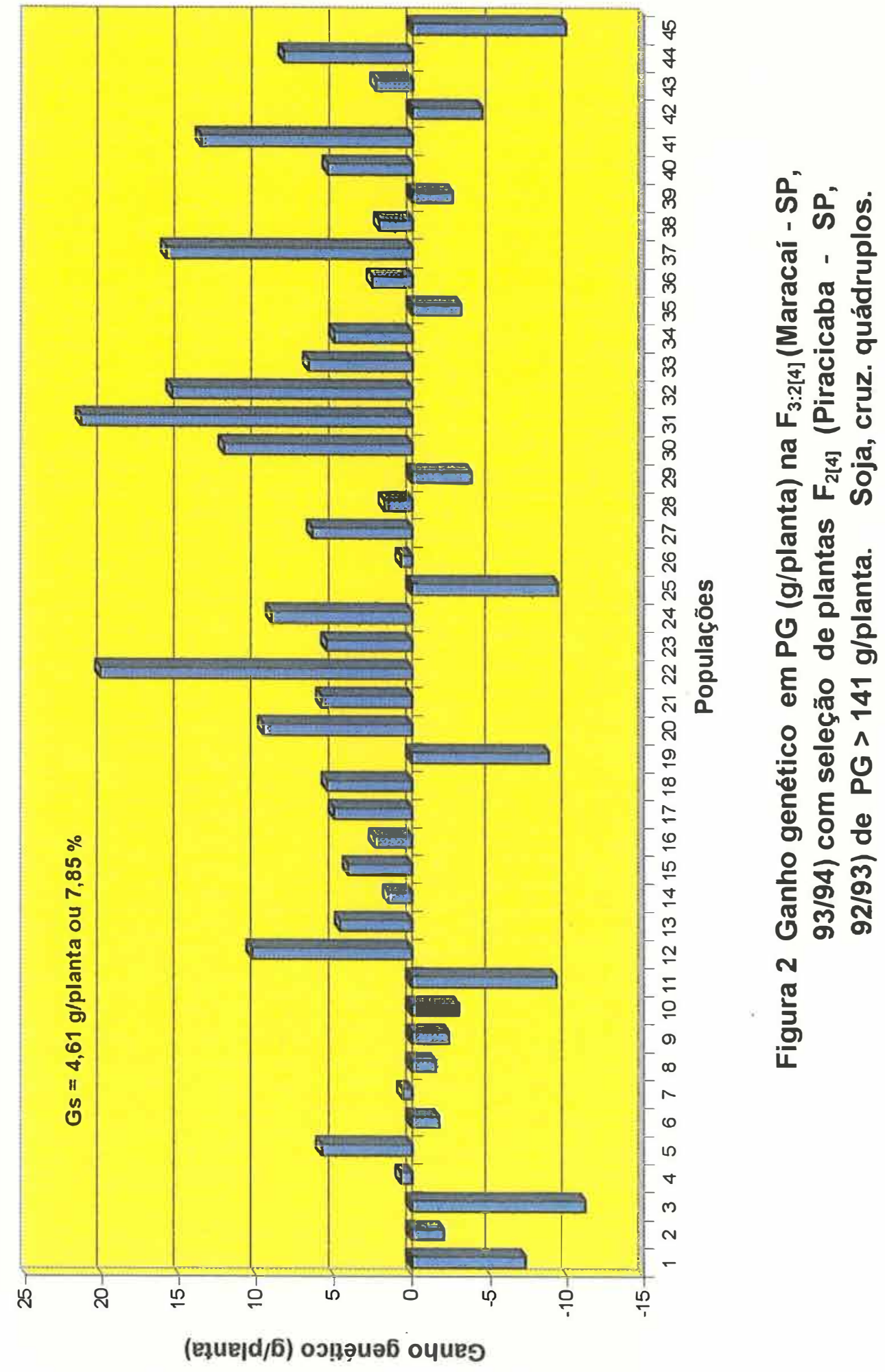




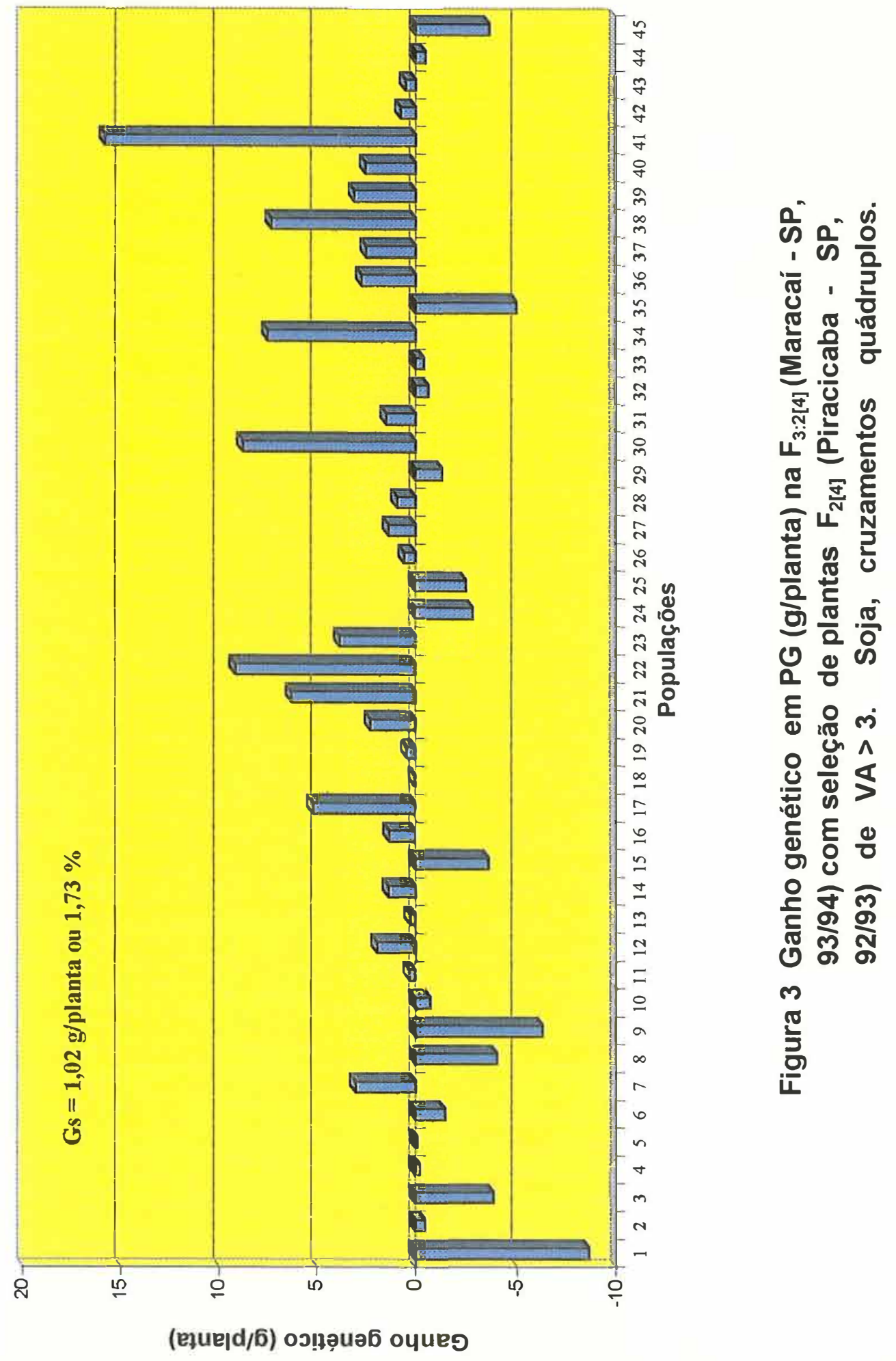




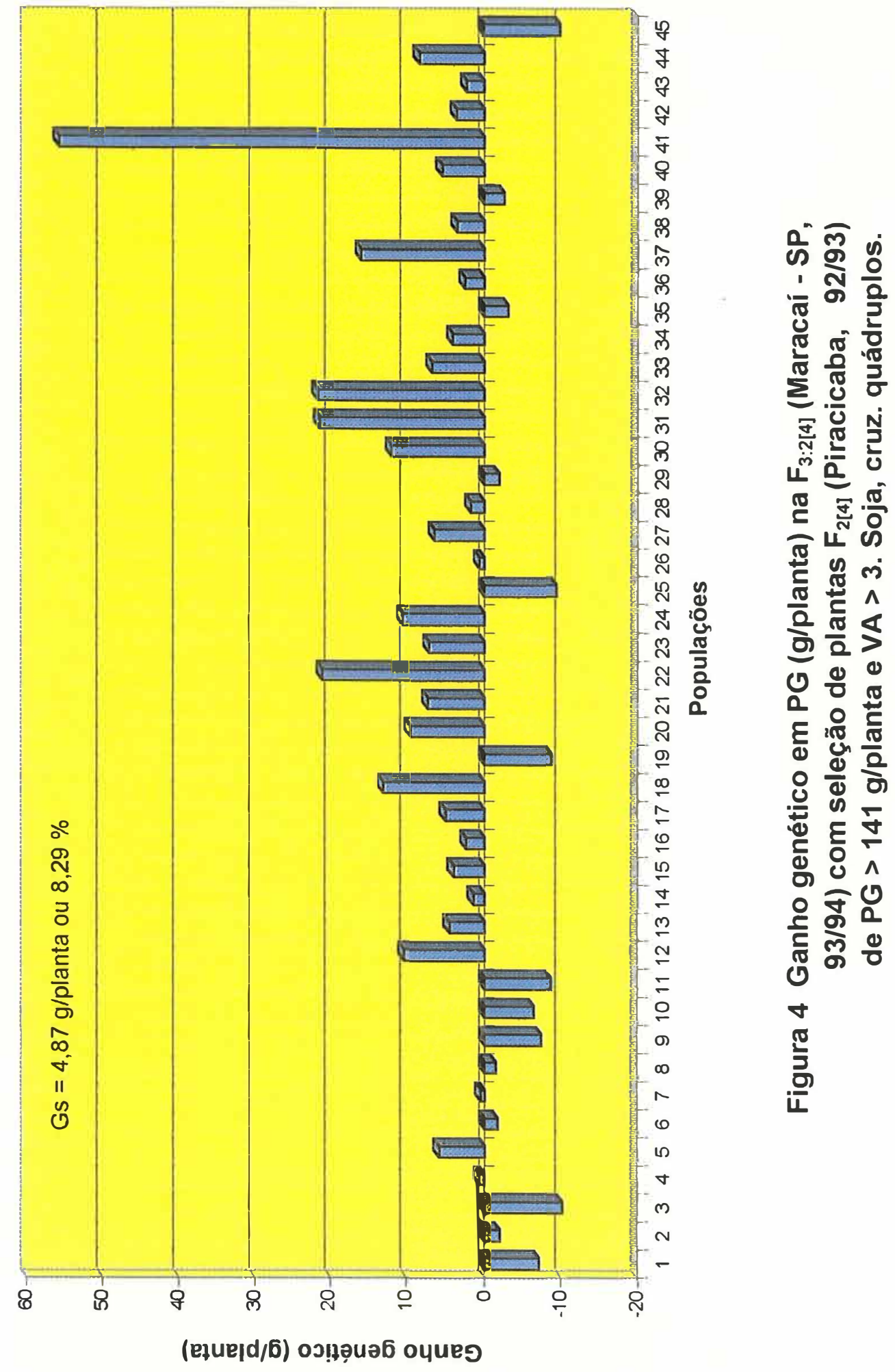




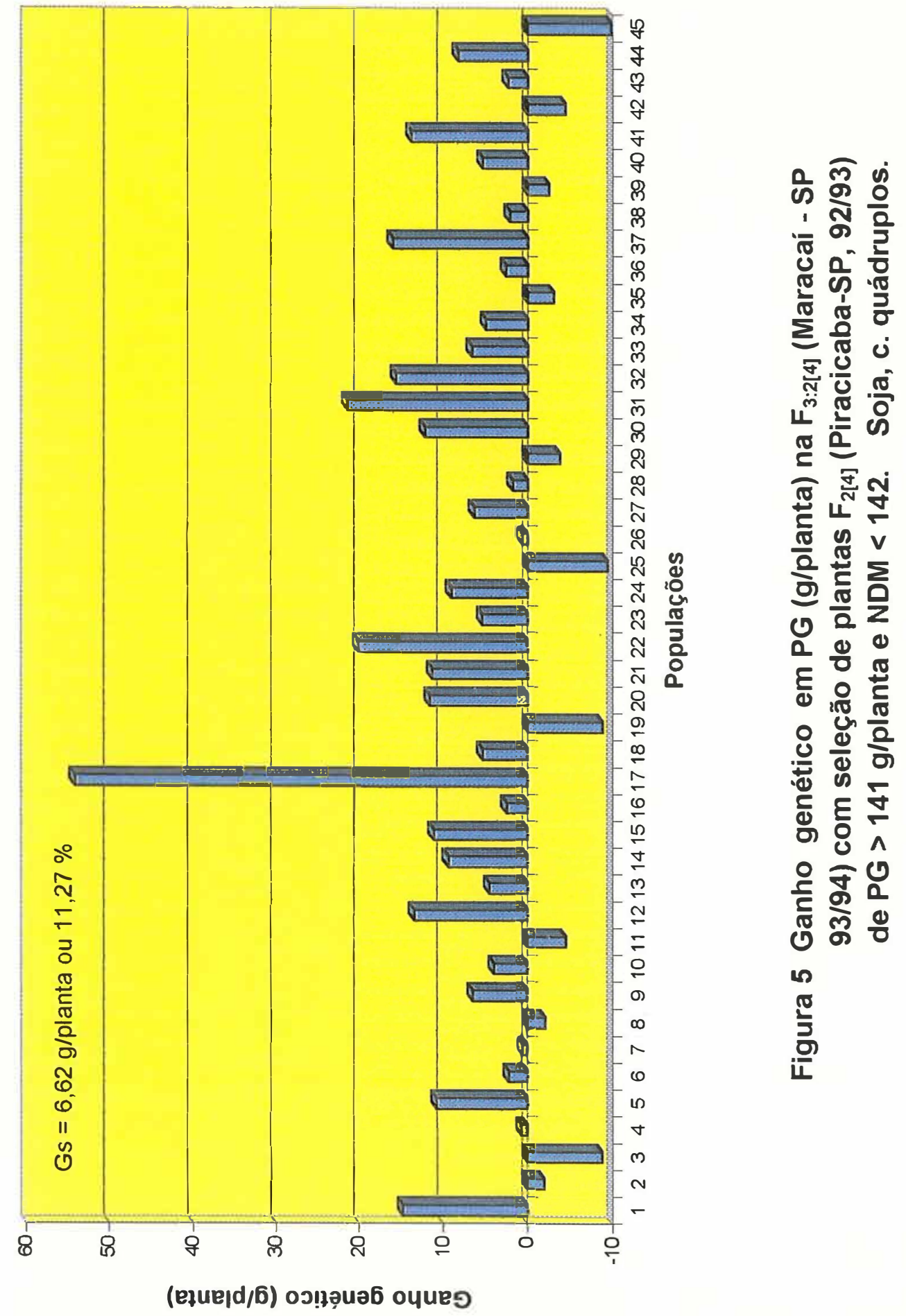




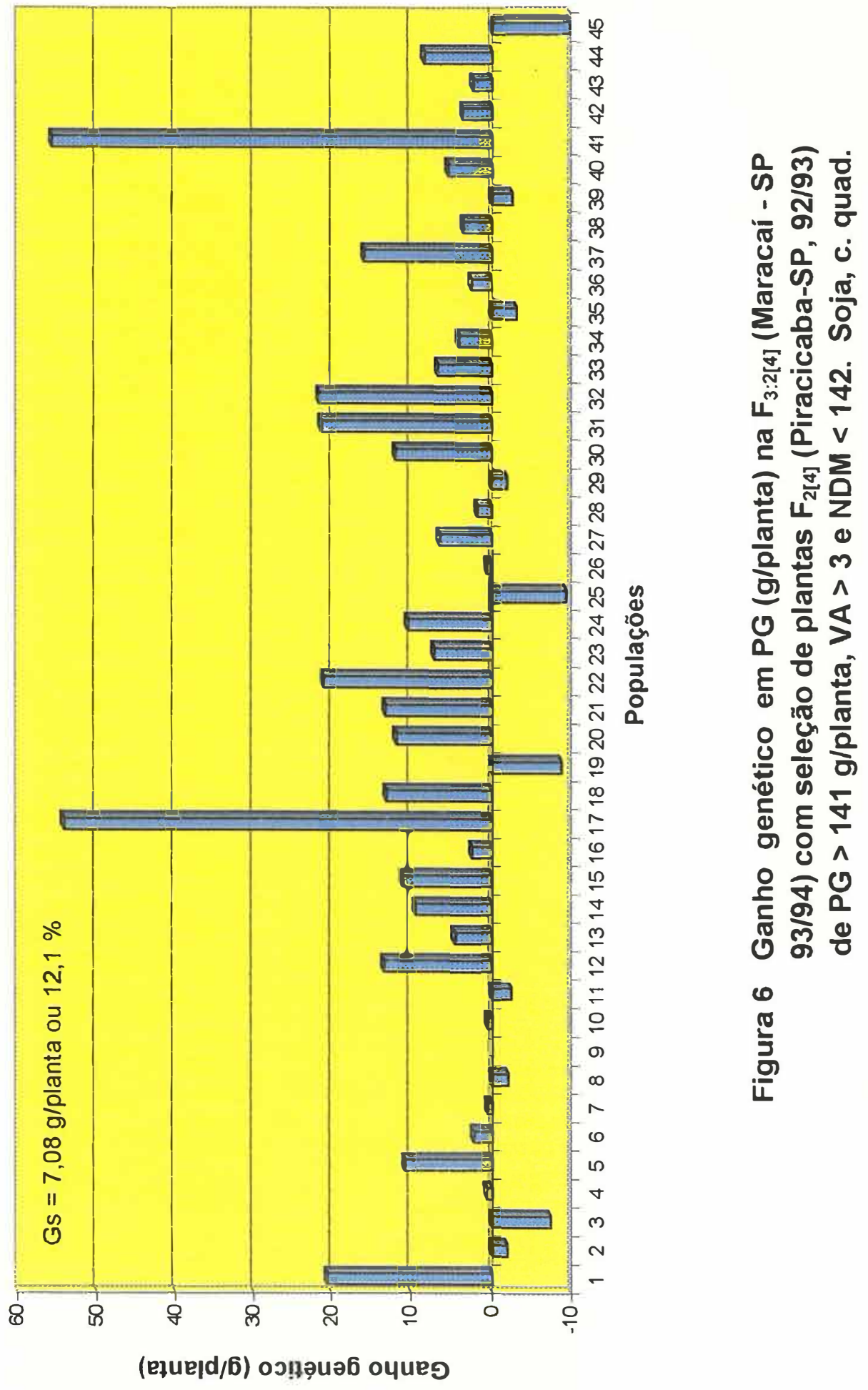




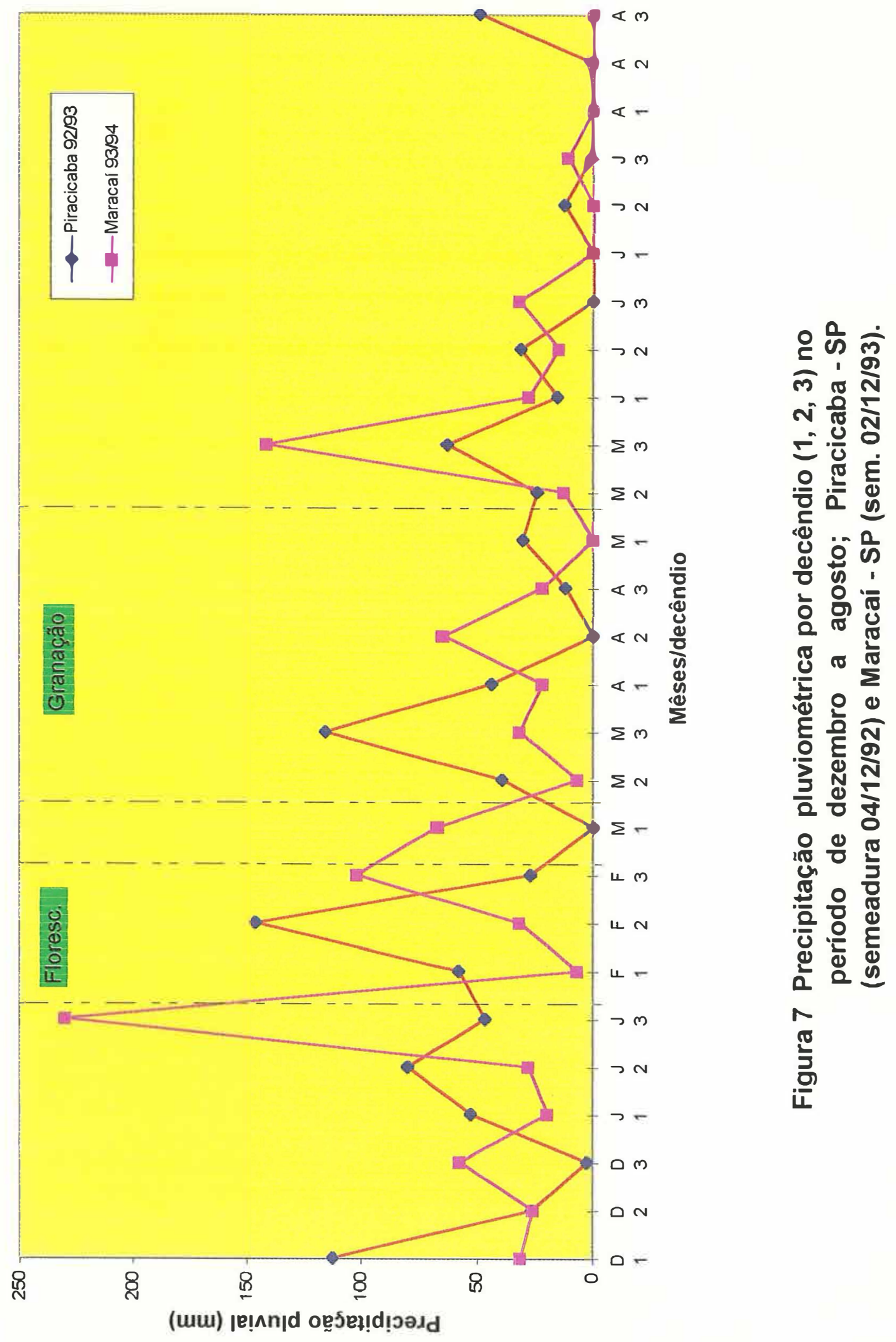




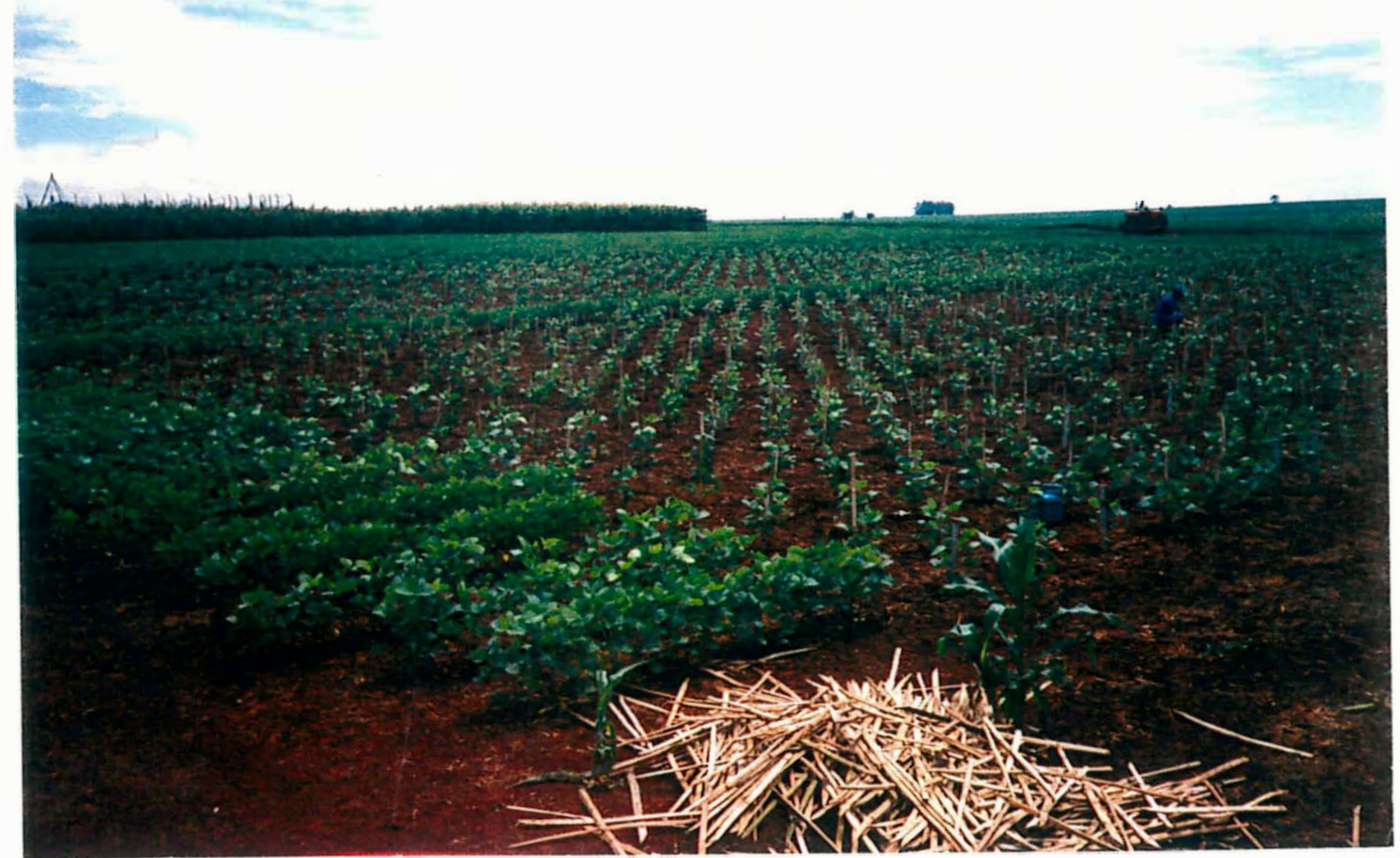

Figura 8 Vista parcial em diagonal do experimento na Área Experimental da Cooperativa Riograndense. Soja. Maracaí - SP, semeadura em 02/12/93.

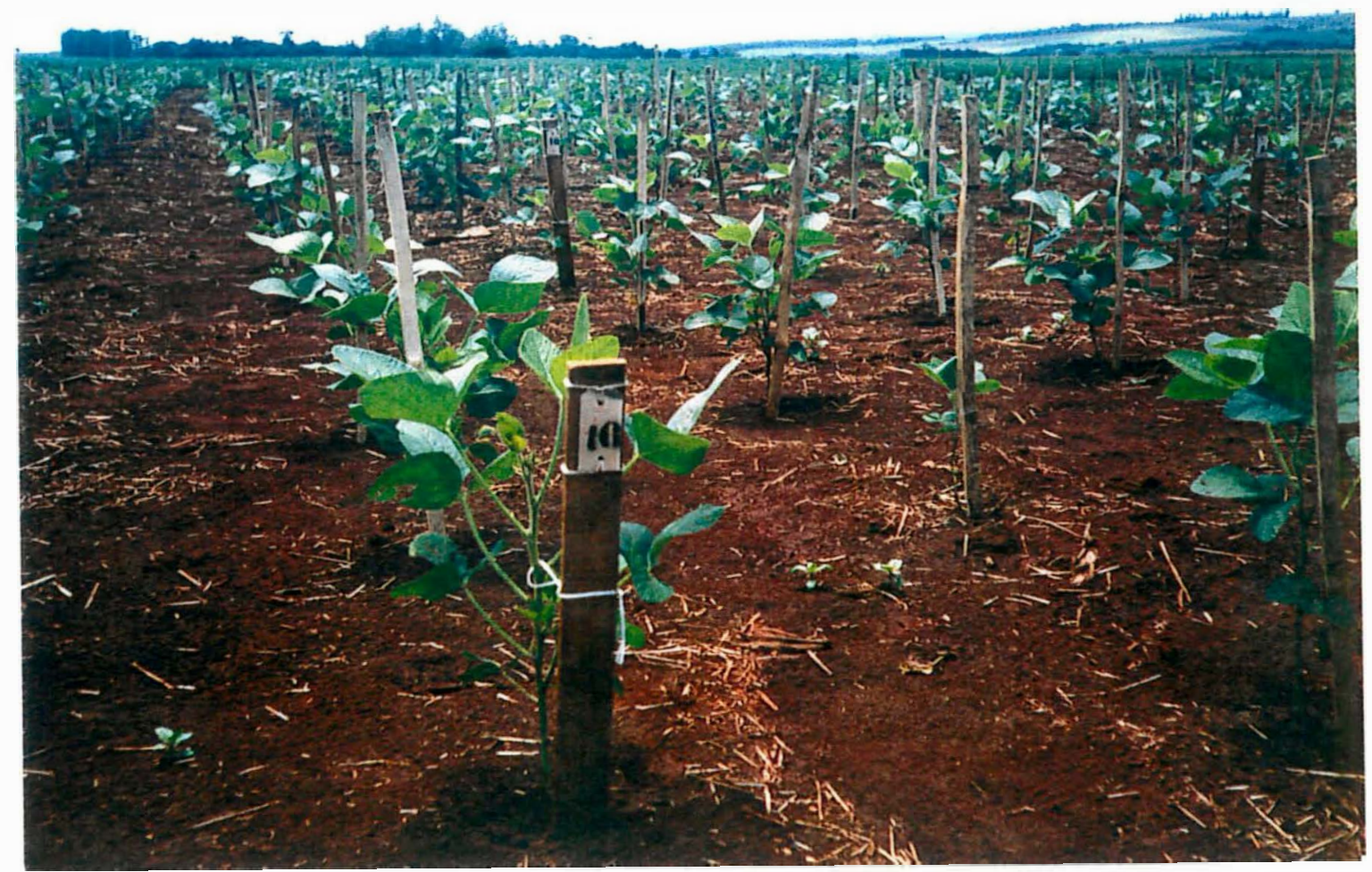

Figura 9 Vista da parcela de 12 covas com plantas individuais estacpueadas. Soja. Maracaí - SP (semeadura 02/12/93). 
APÊNDICES 
Apêndice 1A) Genealogia e modo de obtenção das testemunhas e dos parentais utilizados nos 45 cruzamentos quádruplos em Soja.

\begin{tabular}{|c|c|c|c|c|}
\hline $\begin{array}{c}\text { Denominação } \\
\text { do } \\
\text { genótipo }\end{array}$ & Genealogia & $\begin{array}{l}\text { Método } \\
\text { de } \\
\text { melhoram. }\end{array}$ & $\begin{array}{l}\text { Geração } \\
\text { de sele } \\
\text { ção }\end{array}$ & $\begin{array}{l}\text { Ano } \\
\text { de } \\
\text { recom. }\end{array}$ \\
\hline $\begin{array}{l}\text { BR-11 (Carajás) } \\
\text { BR79-63 } \\
\text { EMGOPA-301 } \\
\text { FT-Cristalina } \\
\text { GO79-1039 } \\
\text { IAC-2 } \\
\text { IAC-4 } \\
\text { IAC-5 } \\
\text { IAC-6 } \\
\text { IAC-8 } \\
\text { IAC-9 } \\
\text { IAC-11 } \\
\text { IAC80-3006 } \\
\text { Numbaira } \\
\text { OCEPAR } 9 \text { - SS } 1^{a} \\
\text { Paranagoiana } \\
\text { Santa Rosa } \\
\text { Timbira } \\
\text { Tropical } \\
\text { White Biloxi }\end{array}$ & 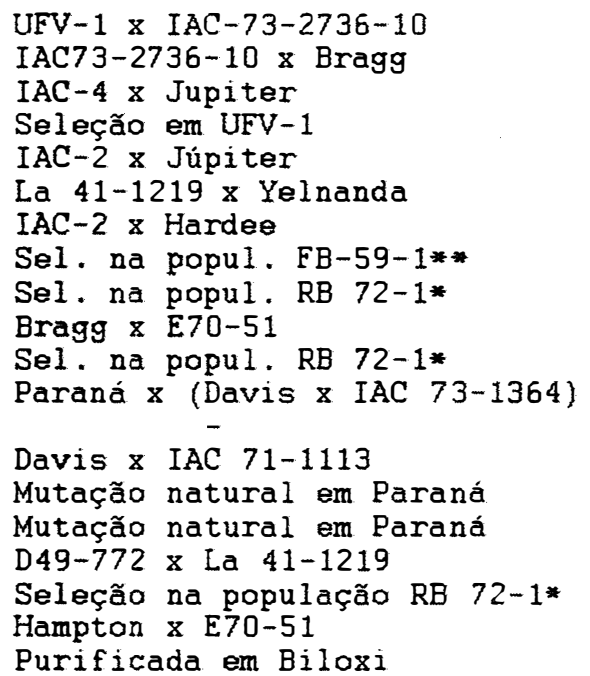 & $\begin{array}{l}\text { Genealógico } \\
\text { Genealógico } \\
\text { Genealógico } \\
\text { Bulk } \\
\text { Genealógico } \\
\text { Genealógico } \\
\text { Bulk } \\
\text { Bulk } \\
\text { Genealógico } \\
\text { Bulk } \\
\text { Genealógico } \\
\text { - } \\
\text { Genealógico } \\
\quad- \\
\text { - } \\
\text { Genealógico } \\
\text { Bulk e Geneal. } \\
\text { Genealógico } \\
\text { - }\end{array}$ & $\begin{array}{l}F_{6} \\
F_{6} \\
F_{4} \\
- \\
- \\
- \\
F_{4} \\
F_{11} \\
- \\
F_{5} \\
- \\
F_{4} \\
- \\
F_{6} \\
- \\
- \\
- \\
F_{7} \\
F_{7} \\
F_{6}\end{array}$ & $\begin{array}{c}1983 \\
- \\
1981 \\
1979 \\
- \\
1967 \\
1975 \\
1975 \\
1979 \\
1980 \\
1981 \\
1984 \\
- \\
1980 \\
1987 \\
1982 \\
1967 \\
1982 \\
1980 \\
-\end{array}$ \\
\hline
\end{tabular}

a Testemunhas utilizadas para comparações com as 45 populações $F_{2}$ e $F_{3}$.

* RB 72-1 = [E70-46 \& Viçoja; E70-47 × Viçoja; Hill \& E70-47; E70-46 \& Pickett: E70-47 \& F65-1376 e Davis x IAC 70-308]

* FB 59-1 = [D49-2491 x PI 171439; D49-2491 (2) \& PI 240664 (Determinado); D49-2491 (2) x PI 240664 (Indeterminado): D51-5091 x Nanda: D51-5091 x Seminale: D51-5091 x FC 30967; D51-5091 x FC 31737; D51-5091 x PI 159095; D51-5091 x PI 200464; D51-5091 x PI 200466; D51-5091 $x$ PI 200488; D51-5091 x PI 200538; D51-5091 x PI 200525; D51-5091 x PI 203400; D51-5091 x PI 210348; F55-35 x Seminole; F55-35 x PI200452: F55-1031 x Majos; F55-1031 x (Roanoke $x$ CNS-4): F55-1031 x PI 159927; F55-1766 x PI 71557 e Seminole x F55-822]

FONTE : ALMEIDA et al. (1991b).

B) Símbolos utilizados para identificação dos caracteres

NDF: Número de Dias para o Florescimento (dias)

APF: Altura da Planta no Florescimento (cm)

NDM: Número de Dias para a Maturidade (dias)

APM: Altura de Planta na Maturidade (cm)

VA: Valor Agronômico ( $1=$ péssimo a $5=$ excelente $)$

PG: Produtividade de Grãos (gramas por planta) 
Apêndice 2 Características agronômicas dos parentais utilizados nos cruzamentos quádruplos na localidade de Londrina - PR. Soja.

\begin{tabular}{|c|c|c|c|c|c|c|c|c|}
\hline \multirow{3}{*}{ PARENTAIS } & \multicolumn{8}{|c|}{ CARACTERISTICAS AGRONÔMICAS* } \\
\hline & NDF & NDM & APM & IPV & $\mathrm{AC}$ & & DEI & PCS \\
\hline & $--c$ & as-- & $--\mathrm{cm}$ & -- & & nota & - & g \\
\hline BR-11 (Carajás) & 86 & 164 & 110 & 14 & 1 & & 1 & 14 \\
\hline BR79-63 & - & - & - & - & - & & - & - \\
\hline EMGOPA-301 & 78 & 143 & 115 & 10 & 4 & & 1 & 15 \\
\hline FT-Cristalina & 67 & 149 & 80 & 12 & 3 & & 1 & 14 \\
\hline G079-1039 & - & - & - & - & - & & - & - \\
\hline IAC- 2 & 46 & 114 & 70 & 14 & 2 & & 1 & 16 \\
\hline$I A C-4$ & 58 & 129 & 76 & 10 & 1 & & 1 & 10 \\
\hline$I A C-5$ & 54 & 126 & 110 & 14 & 3 & & 1 & 16 \\
\hline$I A C-6$ & 78 & 151 & 110 & 12 & 2 & & 1 & 14 \\
\hline IAC- 8 & 55 & 129 & 100 & 10 & 3 & & 1 & 18 \\
\hline IAC -9 & 70 & 139 & 92 & 10 & 2 & & 1 & 14 \\
\hline IAC-11 & 58 & 131 & 108 & 14 & 1 & & 1 & 12 \\
\hline$I A C-80-3006$ & - & - & - & - & - & & - & - \\
\hline Numbaira & 67 & 138 & 94 & 10 & 2 & & 1 & 12 \\
\hline OCEPAR $9-$ SS 1 & 55 & 121 & 98 & 16 & 2 & & 1 & 16 \\
\hline Paranagoiana & 67 & 134 & 98 & 14 & 1 & & 1 & 16 \\
\hline Santa Rosa & 58 & 128 & 79 & 12 & 2 & & 1 & 17 \\
\hline Timbira & 80 & 162 & 96 & 12 & 2 & & 1 & 14 \\
\hline Tropical & 77 & 155 & 123 & 13 & 2 & & 1 & 14 \\
\hline White Biloxi & 62 & 154 & 102 & 11 & 2 & & 1 & 15 \\
\hline
\end{tabular}

*ESCALA DE NOTAS: ACAMAMENTO (AC) / DEISCÊNCIA (DEI)

1: Resistente 2: Moderadamente resistente

4: Susceetivel 3: Moderadamente suscetivel

NDF: Número de Dias para o Florescimento (dias)

NDM: Número de Dias para a Maturidade (dias)

APM: Altura da Planta na Maturidade (cm)

IPV: Inserção da Primeira Vagem $(\mathrm{cm})$

PCS: Peso de Cem Sementes (gramas)

FONTE: ALMEIDA et al. (1991a). 
Apêndice 3 Reação aos patógenos dos 20 parentais utilizados nos cruzamentos quádruplos em Soja.

CULTIVARES

REAÇAO ÀS DOENÇAS ${ }^{a}$

$\mathrm{MP} M \mathrm{M}$ Crs Cer Mil Sep Pus Inc Jav $\mathrm{CHS}_{\mathrm{C}}^{\mathrm{C}}$

\begin{tabular}{|c|c|c|c|c|c|c|c|c|c|c|}
\hline BR-11 (Carajás) & 3 & 4 & 4 & 4 & 3 & 3 & 1 & 4 & 4 & 4 \\
\hline BR79-63 & - & - & - & - & - & - & - & - & - & - \\
\hline EMGOPA-301 & 2 & 4 & 4 & 4 & 2 & 3 & 1 & 4 & 1 & 2 \\
\hline FT-Cristalina & 2 & 4 & 4 & 1 & 1 & 3 & 1 & 4 & 4 & 4 \\
\hline GO79-1039 & - & - & - & - & - & - & - & - & - & - \\
\hline$I A C-2$ & 2 & 4 & 4 & 1 & 2 & 3 & 4 & 4 & 4 & 1 \\
\hline$I A C-4$ & 2 & 4 & 1 & 2 & 2 & 2 & 1 & 4 & 4 & 4 \\
\hline$I A C-5$ & 2 & 4 & 4 & 4 & 2 & 3 & 1 & 4 & 4 & 4 \\
\hline$I A C-6$ & 2 & 4 & 4 & 4 & 3 & 3 & 1 & 4 & 4 & 4 \\
\hline IAC -8 & 2 & 4 & 4 & 4 & 2 & 3 & 1 & 1 & 4 & 4 \\
\hline IAC-9 & 1 & 1 & 4 & 4 & 3 & 3 & 1 & 4 & 4 & 3 \\
\hline$I A C-11$ & 2 & 1 & 1 & 1 & 2 & 3 & 1 & 4 & 4 & 3 \\
\hline IAC $80-3006$ & - & - & - & - & - & - & - & - & - & - \\
\hline Numbaira & 2 & 1 & 1 & 1 & 3 & 3 & 1 & 4 & 4 & 2 \\
\hline OCEPAR 9 - SS 1 & 2 & 4 & 4 & 1 & 3 & 2 & 1 & 4 & 4 & 4 \\
\hline Paranagoiana & 2 & 4 & 1 & 1 & 3 & 2 & 1 & 4 & 4 & 3 \\
\hline Santa Rosa & 1 & 4 & 4 & 4 & 2 & 3 & 1 & 4 & 4 & 1 \\
\hline Timbira & 2 & 4 & 4 & 4 & 2 & 3 & 1 & 4 & 4 & 3 \\
\hline Tropical & - & 4 & 4 & 4 & 1 & 2 & 1 & 1 & 4 & 3 \\
\hline White Biloxi & - & - & - & - & - & - & - & - & - & - \\
\hline
\end{tabular}

${ }^{a}$ ESCALA DE NOTAS PARA REAÇÃO AOS PATÓGENOS:

\section{1: Resistente 2: Moderadamente resistente \\ 4: Suscetivel 3: Moderadamente suscetivel}

DOENÇAS: MP: mancha púrpura causada por Cercospora kikuchi

MC: Virus do mosaico comum da soja

Crs: crestamento bacteriano-Pseudomonas syringae pv.glycinea

Cer: mancha "olho de rã" - Cercospora sojina

Mil: míldio pulvurulento - Peronospora manshurica

Sep: mancha parda:Septoria glycines

Inc: nematóide de galha - Meloidogyne incognita

Jav: nematóide de galha - Meloidogyne javanica

CHS: Cancro da $\operatorname{Haste}^{\mathrm{b}}(\mathrm{C}=$ Campo $\mathrm{P}=$ Palito $)$

${ }^{\mathrm{b}}$ Diaporthe phaseolorum f. sp. meridionalis (teleom.) Phomopsis phaseoli f. sp. meridionalis (anam.).

FONTES: ALMEIDA et al. (1991a); EMBRAPA (1994); EMBRAPA (1995); YORINORI et al. (1993). 
Apêndice 4 Características botânicas dos parentais utilizados nos cruzamentos quádruplos em Soja.

\begin{tabular}{|c|c|c|c|c|c|c|c|c|}
\hline \multirow[b]{2}{*}{ CULTIVARES } & \multicolumn{6}{|c|}{ CARACTERISTICAS BOTÂNICAS } & \multirow[b]{2}{*}{$\begin{array}{l}\text { HÁ } \\
\text { BI } \\
\text { TO }\end{array}$} & \multirow[b]{2}{*}{$\begin{array}{c}\text { PERO } \\
\text { XIDA } \\
\text { SE }\end{array}$} \\
\hline & $\begin{array}{l}\text { Hipo } \\
\text { cot. }\end{array}$ & Flor & $\begin{array}{c}\text { Pubes } \\
\text { cen. }\end{array}$ & $\begin{array}{l}\text { Vagem } \\
\text { Vagem }\end{array}$ & $\begin{array}{c}\text { Teg d da } \\
\text { sem. }\end{array}$ & Hilo & & \\
\hline BR-11 (Carajás) & $\mathrm{RO}$ & $\mathrm{RO}$ & $M A$ & MC & $\mathrm{AM} B \mathrm{BR}$ & $M A$ & $\mathrm{DET}$ & + \\
\hline BR79-63 & RO & RO & $\mathrm{MA}$ & $\mathrm{MC}$ & $-\quad-$ & - & - & . \\
\hline EMGOPA-301 & $\mathrm{RO}$ & RO & $M A$ & $\mathrm{MC}$ & $\mathrm{AM} B \mathrm{BR}$ & $\mathrm{MA}$ & DET & + \\
\hline FT-Cristalina & $\mathrm{RO}$ & RO & CI & MC & AM BR & $\mathrm{MC}$ & $\mathrm{DET}$ & + \\
\hline GO79-1039 & $\mathrm{RO}$ & RO & $M A$ & $\mathrm{MC}$ & $-\quad-$ & - & - & . \\
\hline IAC- 2 & VE & $\mathrm{BR}$ & CI & $\mathrm{MC}$ & $A M \quad B R$ & $\mathrm{MC}$ & IND & + \\
\hline $\mathrm{IAC}-4$ & $\mathrm{VE}$ & $\mathrm{BR}$ & CI & $M C$ & $A M F O$ & $M A$ & $\mathrm{DET}$ & + \\
\hline IAC- 5 & $\mathrm{RO}$ & RO & $M A$ & $\mathrm{MC}$ & $\mathrm{AM} F \mathrm{FO}$ & $\mathrm{PR}$ & IND & + \\
\hline IAC- 6 & RO & RO & $M A$ & MC & $\mathrm{AM} B \mathrm{BR}$ & $M A$ & DET & + \\
\hline IAC- 8 & RO & $\mathrm{RO}$ & $\mathrm{MA}$ & $M C$ & $A M S B R$ & $\mathrm{PR}$ & $\mathrm{DET}$ & - \\
\hline$I A C-9$ & RO & $\mathrm{RO}$ & CI & $M C$ & $A M B R$ & $\mathrm{MC}$ & $\mathrm{DET}$ & + \\
\hline IAC- 11 & VE & $\mathrm{BR}$ & CI & ME & $\mathrm{AM} B \mathrm{BR}$ & $\mathrm{MC}$ & DET & + \\
\hline IAC $80-3006$ & VE & $\mathrm{BR}$ & $M A$ & MC & - & - & - & . \\
\hline Numbaira & $\mathrm{RO}$ & RO & $M A$ & $\mathrm{MC}$ & $A M F O$ & PR & $\mathrm{DET}$ & - \\
\hline OCEPAR 9 - SS 1 & VE & $\mathrm{BR}$ & CI & $\mathrm{ME}$ & $\mathrm{AM}$ BR & $\mathrm{MC}$ & $\mathrm{DET}$ & +- \\
\hline Paranagoiana & VE & $\mathrm{BR}$ & $C I$ & $M E$ & $A M F O$ & $\mathrm{MC}$ & $\mathrm{DET}$ & + \\
\hline Santa Rosa & VE & $\mathrm{BR}$ & $M A$ & MC & $A M B R$ & $\mathrm{MA}$ & $\mathrm{DET}$ & + \\
\hline Timbira & $\mathrm{RO}$ & $\mathrm{RO}$ & $M A$ & $\mathrm{MC}$ & $\mathrm{AM} B \mathrm{BR}$ & $\mathrm{MA}$ & $\mathrm{DET}$ & - \\
\hline Tropical & $\mathrm{RO}$ & RO & MA & $\mathrm{MC}$ & $A M \quad S B R$ & PR & $\mathrm{DET}$ & - \\
\hline White Biloxi & $\mathrm{RO}$ & RO & $M A$ & MC & $A M \quad-$ & $\mathrm{MA}$ & $\mathrm{DET}$ & . \\
\hline
\end{tabular}

\section{DESCRITORES:}

HÁBITO DE CRESCIMENTO - DET: Determinado IND: Indeterminado

COR - Hipocótilo Verde (VE) Roxa (RO)

- Flor Branca (BR) Roxa (RO)

- Pubescência Cinza (CI) Marrom (MA)

- Vagem Preta (PR) Marrom (MA)

- Tegumento da Semente Amarelo (AM) Brilhante (BR)

Fosco (FO) Semi Brilhante (sBR)

FONTE: ALMEIDA et al. (1991a) 
Apêndice 5 Teores $(\%)$ de óleo, proteína, sabor (nota) e àrea de recomendação dos parentais utilizados nos cruzamentos quádruplos em soja.

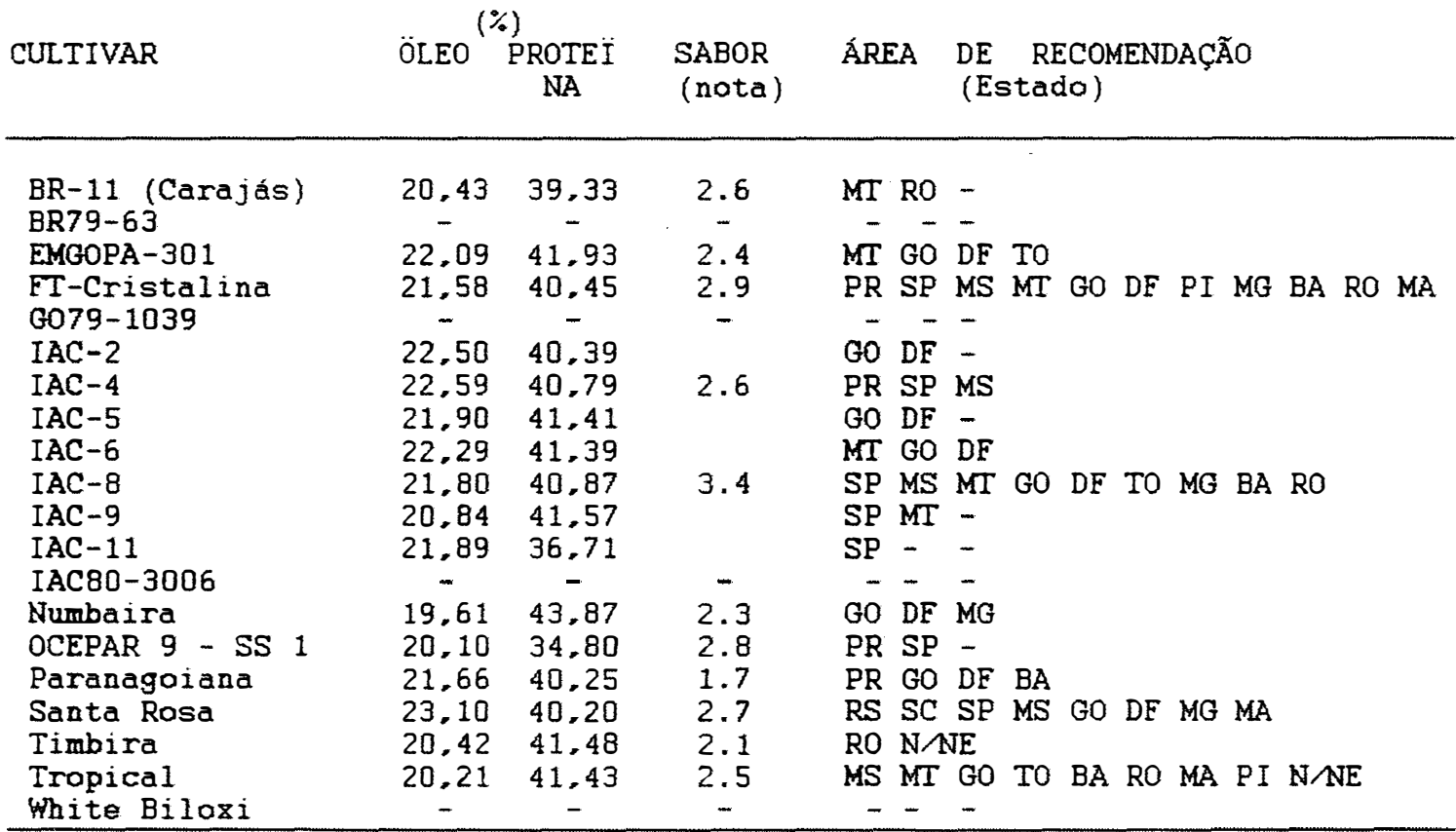

SABOR: 1-Muito ruim (amargo, rançoso) 4-Bom (Doce com leve sabor amargo)

2-Ruim (amargo) 5-Muito bom (Doce)

3-Intermediário

ÁREA DE RECOMENDAÇÃO: Siglas dos Estados Brasileiros onde estes cultivares foram ou ainda são recomendados.

FONTE: ALMEIDA et al. (1991a); EMBRAPA, 1994; EMBRAPA, 1995. 
Apêndice 6 Composição dos 45 cruzamentos quádruplos de soja (populações), e respectivo número de sementes híbridas viáveis $(\mathrm{N})$ obtidas, a partir do cruzamento dialélico $10 \times 10$ entre parentais semitardios e tardios em 1989/90. Soja. Piracicaba.

\begin{tabular}{|c|c|c|c|c|}
\hline POPULAÇÕES & GRUPO SEMI-TARDIO & $\mathrm{X}$ & GRUPO TARDIO & $\mathrm{N}$ \\
\hline 1 & (Cristalina $x$ EMGOPA-301) & $\mathrm{X}$ & $(\mathrm{BR}-11 \times \mathrm{BR} 79-63)$ & 4 \\
\hline 2 & (Cristalina x IAC-4) & $\mathrm{X}$ & (BR-11 x G079-1039) & 17 \\
\hline 3 & (Cristalina $\times$ IAC-5) & $\mathrm{X}$ & $(\mathrm{BR}-11 \times \mathrm{IAC}-2)$ & 10 \\
\hline 4 & (Cristalina x IAC-6) & $\mathrm{X}$ & (BR-11 x IAC80-3006) & 11 \\
\hline 5 & (Cristalina x IAC-8) & $\mathrm{X}$ & (BR-11 x Numbaira) & 5 \\
\hline 6 & (Cristalina $\times$ IAC-9) & $\mathrm{X}$ & (BR-11 x Paranagoiana) & 7 \\
\hline 7 & (Cristalina x IAC-11) & $\mathrm{X}$ & (BR-11 x Timbira) & 16 \\
\hline 8 & (Cristalina x Santa Rosa) & $\mathrm{X}$ & (BR-11 x Tropical) & 18 \\
\hline 9 & (Cristalina x SS-1) & $\mathrm{X}$ & (BR-11 x White Biloxi) & 5 \\
\hline 10 & (EMGOPA-301 x IAC-4) & $\mathrm{X}$ & (BR79-63 x GO79-1039) & 4 \\
\hline 11 & (EMGOPA-301 x IAC-5) & $\mathrm{X}$ & (BR79-63 x IAC-2) & 16 \\
\hline 12 & (EMGOPA-301 x IAC-6) & $\mathrm{X}$ & (BR79-63 x IAC80-3006) & 5 \\
\hline 13 & (EMGOPA-301 x IAC-8) & $\mathrm{X}$ & (BR79-63 x Numbaira) & 12 \\
\hline 14 & (EMGOPA-301 x IAC-9) & $\mathrm{X}$ & (BR79-63 x Paranagoiana) & 5 \\
\hline 15 & (EMGOPA-301 x IAC-11) & $\mathrm{X}$ & (BR79-63 x Timbira) & 9 \\
\hline 16 & (EMGOPA-301 x Santa Rosa) & $\mathrm{X}$ & (BR79-63 x Tropical) & 9 \\
\hline 17 & (EMGOPA-301 x SS-1) & $\mathrm{X}$ & (BR79-63 x White Biloxi) & 6 \\
\hline 18 & (IAC-4 $\times$ IAC-5) & $\mathrm{X}$ & (G079-1039 x IAC-2) & 32 \\
\hline 19 & (IAC-4 x IAC-6) & $\mathrm{X}$ & (G079-1039 x IAC80-3006) & 8 \\
\hline 20 & (IAC-4 x IAC-8) & $\mathrm{X}$ & (G079-1039 x Numbaira) & 10 \\
\hline 21 & (IAC-4 x IAC-9) & $\mathrm{X}$ & (G079-1039 x Paranagoiana) & 9 \\
\hline 22 & $($ IAC- $-4 \times$ IAC-11) & $\mathrm{X}$ & (G079-1039 x Timbira) & 5 \\
\hline 23 & (IAC-4 x Santa Rosa) & $\mathrm{X}$ & (G079-1039 x Tropical) & 19 \\
\hline 24 & (IAC-4 x SS-1) & $\mathrm{X}$ & (G079-1039 x White Biloxi) & 14 \\
\hline 25 & (IAC-5 x IAC-6) & $\mathrm{X}$ & (Tropical x White Biloxi) & 5 \\
\hline 26 & (IAC-5 x IAC-8) & $\mathrm{X}$ & (Tropical x Numbaíra) & 9 \\
\hline 27 & (IAC-5 x IAC-9) & $X$ & (Tropical x Paranagoiana) & 6 \\
\hline 28 & (IAC-5 x IAC-11 & $\mathrm{X}$ & (Tropical x Timbira) & 6 \\
\hline 29 & (IAC-5 x Santa Rosa) & $\mathrm{X}$ & (Tropical x IAC-2) & 10 \\
\hline 30 & (IAC-5 x SS-1) & $X$ & (Tropical x IAC80-3006) & 9 \\
\hline 31 & (IAC-6 x IAC-8) & $\mathrm{X}$ & (White Biloxi x Numbaira) & 9 \\
\hline 32 & (IAC-6 x IAC-9) & $X$ & (White Biloxi x Paranagoiana) & 5 \\
\hline 33 & (IAC-6 x IAC-11) & $X$ & (White Biloxi x Timbira) & 9 \\
\hline 34 & (IAC-6 x Santa Rosa) & $X$ & (White Biloxi x IAC-2) & 14 \\
\hline 35 & (IAC-6 x SS-1) & $X$ & (White Biloxi x IAC80-3006) & 4 \\
\hline 36 & (IAC-8 x IAC-9) & $\mathrm{X}$ & (Paranagoiana x Numbaíra) & 8 \\
\hline 37 & (IAC-8 x IAC-11) & $X$ & (Paranagoiana x Timbira) & 4 \\
\hline 38 & (IAC-8 x Santa Rosa) & $\mathrm{X}$ & (Paranagoiana x IAC80-3006) & 7 \\
\hline 39 & (IAC-8 x SS-1) & $\mathrm{X}$ & (Numbaíra x IAC80-3006) & 20 \\
\hline 40 & (IAC-9 x IAC-11) & $\mathrm{X}$ & (Numbaira $x$ Timbira) & 11 \\
\hline 41 & (IAC-9 x Santa Rosa) & $\mathrm{X}$ & (IAC-2 x Paranagoiana) & 15 \\
\hline 42 & (IAC-9 x SS-1) & $\mathrm{X}$ & (IAC-2 x Numbaira) & 21 \\
\hline 43 & (IAC-11 x Santa Rosa) & $\mathrm{X}$ & (IAC-2 x Timbira) & 4 \\
\hline 44 & (IAC-11 x SS-1) & $\mathrm{X}$ & (IAC80-3006 x Timbira) & 8 \\
\hline 45 & (Santa Rosa x SS-1) & $\mathrm{X}$ & (IAC80-3006 x IAC-2) & 14 \\
\hline MÉDIA & - & - & - & 10 \\
\hline
\end{tabular}

